\begin{abstract}
Universidade de São Paulo
Faculdade de Filosofia, Letras e Ciências Humanas

Departamento de Letras Modernas

Programa de Pós-graduação em Estudos Linguísticos e Literários em Inglês
\end{abstract}

MARCELO CIZAURRE GUIRAU

\title{
História e forma em Ragtime, The Book of Daniel e Homer \& Langley, de E. L. Doctorow
}

São Paulo

2014

Versão Corrigida 


\author{
Universidade de São Paulo \\ Faculdade de Filosofia, Letras e Ciências Humanas \\ Departamento de Letras Modernas \\ Programa de Pós-graduação em Estudos Linguísticos e Literários \\ em Inglês
}

\title{
História e forma em Ragtime, The Book of Daniel e Homer \& Langley, de E. L. Doctorow
}

\author{
Marcelo Cizaurre Guirau
}

Tese apresentada ao Programa de Pós-graduação em Estudos Linguísticos e Literários em Inglês do Departamento de Letras Modernas da Universidade de São Paulo, como parte dos prérequisitos para a obtenção do título de Doutor em Letras.

Orientadora:

Profa. Dra. Maria Elisa Burgos

Pereira da Silva Cevasco

São Paulo

2014

Versão Corrigida 
Autorizo a reprodução e divulgação total ou parcial deste trabalho, por qualquer meio convencional ou eletrônico, para fins de estudo e pesquisa, desde que citada a fonte.

Catalogação na Publicação

Serviço de Biblioteca e Documentação

Faculdade de Filosofia, Letras e Ciências Humanas da Universidade de São Paulo

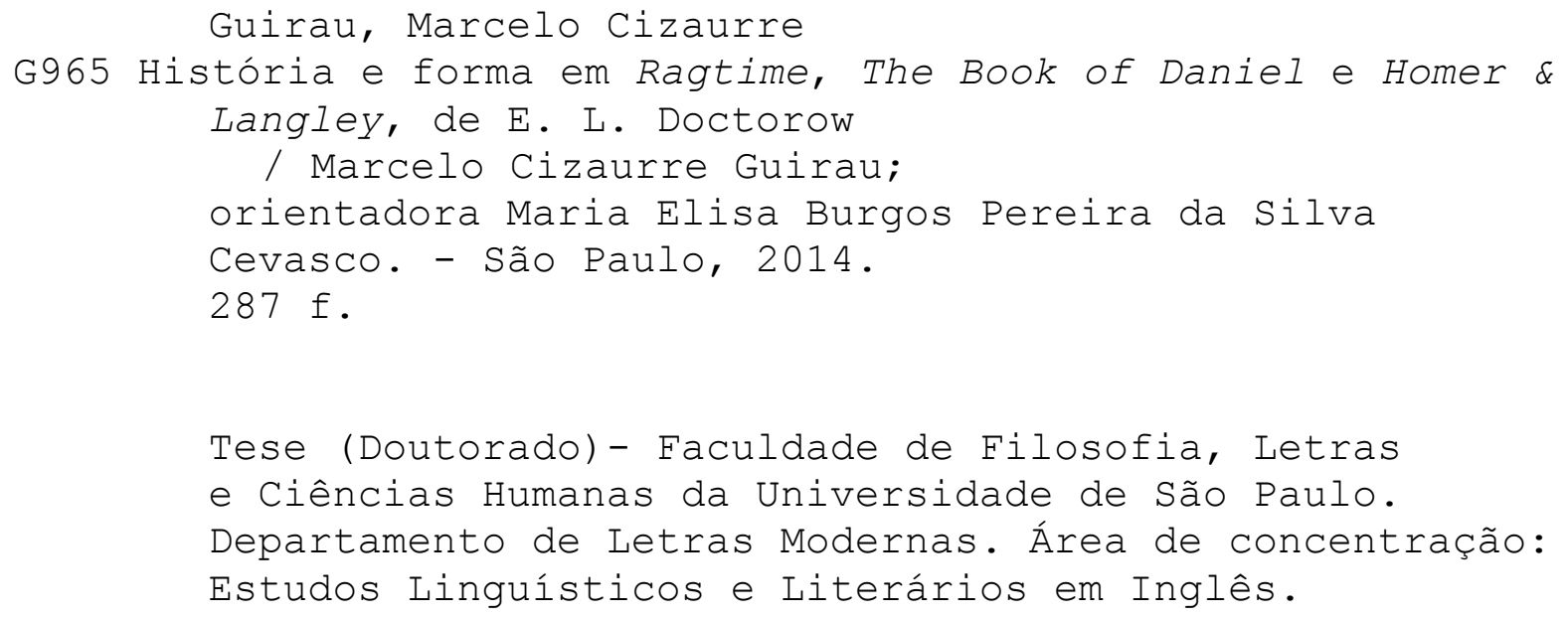

1. LITERATURA NORTE-AMERICANA. 2. ROMANCE HISTÓRICO. I. Cevasco, Maria Elisa Burgos Pereira da Silva, orient. II. Título. 
À Yifang

À Beatriz

Aos meus pais, José e Creuza 


\section{Agradecimentos:}

À minha orientadora, pela generosidade com que sempre me atendeu, pelo encorajamento nos pontos difíceis do projeto e pelo senso crítico na leitura da tese.

Ao professor Marcos Soares, pela ajuda na elaboração do projeto e nos momentos iniciais da pesquisa.

Aos professores Daniel Puglia e Fábio Akcelrud Durão, pelas sugestões dadas no exame de qualificação.

Aos amigos Rafael Mantovani e Andrea Gomes de Alencar, pela ajuda até a última hora.

Ao amigo Alexandre Agnolon, pela leitura atenta da tese e pelas relevantes observações.

Ao Conselho Nacional de Desenvolvimento Científico e Tecnológico (CNPq), que apoiou essa tese com uma bolsa. 
... Civros destes, as ficções que contam, fazem-se, todos e todas, com uma continuada dúvida, com um afirmar reticente, sobretudo a inquietação de saber que nada é verdade e ser preciso fingir que o é, ao menos por um tempo, até não se poder resistir à evidência inapagável da mudança, então vai-se ao tempo que passou, que só ele é verdadeiramente tempo, e tenta-se reconstituir o momento que não soubemos reconhecer, que passava enquanto reconstituíamos outro, e assim por diante, momento após momento, todo romance é isso, desespero, intento frustrado de que o passado não seja coisa definitivamente perdida. Só não se acabou ainda de averiguar se éo romance que impede o homem de esquecer-se, ou se é a impossibilidade do esquecimento que o leva a escrever romances. José Saramago, História do Cerco de Lisboa. 


\section{RESUMO}

GUIRAU, Marcelo Cizaurre. História e forma em Ragtime, The Book of Daniel e Homer \& Langley, de E. L. Doctorow. 2014. 287 f. Tese (Doutorado) - Faculdade de Filosofia, Letras e Ciências Humanas, Universidade de São Paulo, São Paulo, 2014.

As obras do escritor norte-americano Edgar Lawrence Doctorow aqui estudadas desenham um panorama criticamente iluminador da história dos Estados Unidos no século XX. Em The Book of Daniel, acompanhamos a trajetória da Esquerda americana dos anos 30 aos anos 60. Em Ragtime, o cenário histórico é a Belle Époque e a "era do ragtime”, do começo do século XX até a Primeira Guerra Mundial. Em Homer \& Langley, o arco temporal se expande para abrigar grande parte do século - da Primeira Guerra aos anos 80. Nos três romances há uma dialética entre o impulso de suscitar conexões e de figurar um quadro histórico e social mais amplo e a dificuldade de se realizar esse projeto por meio da própria linguagem e lógica da fragmentação, que impedem as articulações e emperram a representação. Nessa tese, procuro ler as ambiguidades e hesitações da forma nesses três romances como "incertezas produtivas" - potenciais lições para o pensamento crítico contemporâneo, o qual tateia certezas num mundo em crise. Romances como Ragtime, The Book of Daniel e Homer \& Langley são animados mais por uma hermenêutica da concretude do que por uma poética da relativização. A análise das estratégias de figuração do material histórico que compõe essas obras mostra como essas três narrativas revigoram o romance histórico na contemporaneidade.

Palavras-chave: E. L. Doctorow, Literatura Norte-Americana, Literatura Contemporânea, História Contemporânea, Romance Histórico. 


\begin{abstract}
GUIRAU, Marcelo Cizaurre. History and form in Ragtime, The Book of Daniel e Homer \& Langley, by E. L. Doctorow. 2014. 287 f. Tese (Doutorado) - Faculdade de Filosofia, Letras e Ciências Humanas, Universidade de São Paulo, São Paulo, 2014.
\end{abstract}

The novels by E. L. Doctorow studied here draw a critically illuminating panorama of American History in the $20^{\text {th }}$ century. In The Book of Daniel, we follow the trajectory of the American Left from the thirties up to the sixties. In Ragtime, the historical scenery is the Belle Époque and the "ragtime era", from the beginning of the century up to World War I. In Homer \& Langley, the time frame is broadened to include almost the entire century - from World War I up to de eighties. In those novels, we find a dialectical relationship between the impulse to bring forth connections and represent a larger social and historical picture, and the difficulty of achieving such a project through the very language and logic of fragmentation which obstructs the making of articulations and renders representation difficult. In this work, I try to read the ambiguities and hesitations of the form in those three novels as "productive uncertainties" - potential lessons to contemporary critical thinking. Novels such as Ragtime, The Book of Daniel e Homer \& Langley are animated more by a hermeneutics of the concrete than by a poetics of relativity. The analysis of the representational strategies those novels employ to depict the historical material from which they are made shows how those narratives reinvigorate the historical novel today.

Keywords: E. L. Doctorow, American Literature, Contemporary Literature, Contemporary History, Historical Novel. 


\section{SUMÁRIO}

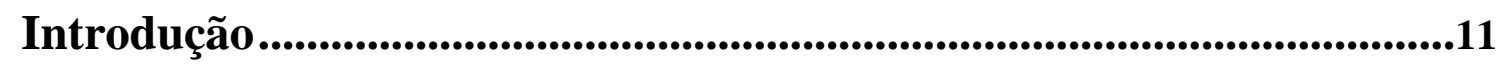

Capítulo 1 - "The novel as a sequence of analyses": a forma possível e as possibilidades da forma em The Book of Daniel. .......................................35

HISTERIA E PERSEGUIÇÃO: OS RoSENBERG E A GUERRA FrIA ........................................ 36

A "ambiguidade Perplexa" do romance: o caso Rosenberg em The PubliC BURNING E THE BOOK OF DANIEL....................................................................... 47

O ETHOS AMBIVALENTE DO NARRADOR EM THE BOOK OF DANIEL …………………..... 55

“TOTALLY DEPRIVED OF THE RIGHT TO BE DANGEROUS" - A ESTERILIDADE POLÍTICA DE DANIEL E O "CASTIGO CORPORAL COMO DISTINÇÃO DE CLASSE". 66

O SACRIFÍCIO REVOLUCIONÁRIO E A HERANÇA SOVIÉTICA: DANIEL RELENDO A HISTÓRIA 70

MAPEANDO AS POSIÇÕES DE ESQUERDA NOS ESTADOS UNIDOS: DUAS LeITURAS DA HISTÓRIA DA REVOLUÇÃo RUSSA 77

UM NARRADOR CONSCIENTE: DANIEL CONFRONTA O LEITOR 92

WHAT IS THE MATTER WITH MY HEART?: A CONFUSÃO DE SENTIMENTOS POLÍTICOS E FAMILIARES DE DANIEL. 98

O PARALELO ENTRE A HISTÓRIA DA ESQUERDA AMERICANA E A INVESTIGAÇÃO FAMILIAR DE DANIEL - O ROMANCE HISTÓRICO E A INTERSECÇÃO DE PLANOS ONTOLÓGICOS. 102

INTERSECÇÕES: DANIEL E A ESQUERDA NORTE-AMERICANA DOS ANOS 60 105

LEITURAS DA DESCONTINUIDADE 111

O MOSAICO NARRATIVO DE THE BOOK OF DANIEL 116 
“THE NOVEL AS A SEQUENCE OF ANALYSES": OS PRINCÍPIOS DE ORGANIZAÇÃO DA NARRATIVA EM THE BOOK OF DANIEL

DANIEL, NARRADOR-PESQUISADOR

DANIEL E A “PRECÁRIA SÍNTESE

Capítulo 2 - História e Figuração em Ragtime

O LUGAR DE RAGTIME NAS DISCUSSÕES SOBRE OS RUMOS DO ROMANCE HISTÓRICO . 158

O JOGO ENTRE FATO E FICÇÃO

O TEMA DA REPRESENTAÇÃO.

LINGUAGEM E ESTILO DE RAGTIME: DistÂNCIA NARRATIVA E "IMITAÇÃO CÔMICA DE TOM HISTÓRICO

“AS IF HISTORY WERE NO MORE THAN A TUNE ON A PLAYER PIANO": A METÁFORA MUSICAL NO ROMANCE

Capítulo 3 - "The strength of no illusions": a organização do pessimismo em Homer \& Langley.

OS “EREMITAS DO HARLEM”. 230

LEVADOS PELOS VENTOS DA HISTÓRIA 235

A ORGANIZAÇÃo DO PESSIMISMO: TEORIA DAS SUBSTITUIÇÕES, COLECIONISMO E GUERRAS.

TESTEMUNHAS DA HISTÓRIA - AGÊNCIA E DETERMINAÇÃO EM TEMPOS SOMBRIOS ... 262

Considerações finais 269

Referências bibliográficas: 272

Obras de E. L. Doctorow: 278

Estudos sobre a obra de E. L. Doctorow: .280 


\section{Introdução}

No ensaio "The Beliefs of Writers" "(1985), E. L. Doctorow afirma que a literatura de ficção de seu tempo sofre de uma "timidez", de uma "modéstia de concepção e linguagem"2". Essa literatura parece, para Doctorow, "circunscrever a análise e a geografia" do escritor, fechar-se dentro de casa e levar uma pacata vida privada ${ }^{3}$. O gesto de recuo em relação ao mundo ${ }^{4}$ implícito nessa "literatura reduzida" é encenado pelos personagens Homer e Langley Collyer no romance que Doctorow publica em 2009. Nele, acompanhamos a história desses dois irmãos nova-iorquinos que decidem fechar-se em casa e viver em isolamento. No entanto, essa existência não é nada pacata: a casa é constantemente invadida pelos ventos da história e lá são depositados detritos de um século catastrófico, como lembranças da inviabilidade do projeto de separação a que os irmaõs Collyer se dedicam. O projeto não realizado - não realizável - dos Collyer figura uma necessidade de engajamento com os problemas do mundo real afim à concepção de Doctorow sobre o trabalho do escritor de ficção hoje: "It is that moving outward, that significant system of judgment, that is missing in much of our work today",

No mesmo ensaio de 1985, Doctorow compara a literatura de seu tempo àquela produzida nos anos 30 - década de acentuadas tensões sociais e de grande engajamento nas artes - e conclui que a atual tranquilidade no campo literário não indica uma

\footnotetext{
${ }^{1}$ DOCTOROW, E. L. Jack London, Hemingway, and the Constitution: selected essays, $1977-$ 1992. New York: Random House, 1993.

${ }^{2}$ Idem.

${ }^{3}$ Idem.

4 "It seems to me quite true of our current, national, psychic state that we are in retreat. Certainly, the predominant trends in recent American fiction are toward privacy and isolation, with the novel's view of its terrain as the interior of a house with the door closed and the shades pulled." (DOCTOROW. In: MORRIS, Christopher D. (ed.) Conversations with E.L. Doctorow. Jackson: University Press of Mississippi, 1999, p. 89)

${ }^{5}$ Idem.

${ }^{6}$ Idem.
} 
equivalente pacificação no campo social: "Literary life in the present is, by comparison [com os anos 30], decorous. It's very quiet today. Is it because our society is sunlit and perfect? Are all our vampires staked through the heart?" $\mathrm{O}$ autor de Ragtime vê na guinada subjetiva da prosa de ficção norte-americana a expressão de uma crise geral de nossa época ${ }^{8}$.

Os romances de Doctorow aqui estudados trazem esse movimento para fora do espaço privado. Seus personagens estão na rua, expostos às intempéries do tempo histórico. Eles confrontam perigos e, na maioria dos casos, caem vítimas da violência de seu tempo ou de sua incapacidade de compreender a direção das forças históricas que os movem.

Além disso, esses romances - sobretudo The Book of Daniel e Ragtime incorporam - de maneira instrutiva, como veremos - a dialética da representação a sua própria forma.

Doctorow é um pesquisador de formas literárias. Sem incorrer em pirotecnia formal, ele compreende a necessidade artística que cada narrativa lhe impõe e não se prende a modelos literários, procurando reinventar a forma sempre que necessário: "The novel has to constantly recreate itself by assaulting its own traditions, the form has to be abused somehow in order to be re-invented each time you write a book ${ }^{9 \%}$.

Uma consequência visível dessa pesquisa formal é a falta de unidade estilística entre os romances. Embora haja na obra uma recorrência de temas e a repetição de alguns cenários, personagens e episódios, estilisticamente cada livro é único. Doctorow explica

\footnotetext{
${ }^{7}$ Idem.

8 "Thus, ironically, in our withdrawal, our nonpolitical pragmatic vision of ourselves and our calling, we writers may be expressing the general crisis of our age." (Idem.)

${ }^{9}$ DOCTOROW. In: MORRIS, op. cit., p. 10.
} 
não ter um estilo, mas que seus livros têm, e que cada um deles requer seu próprio método de apresentação ${ }^{10}$.

Seu romance de estreia é um exercício de criação a partir de um gênero romanesco tipicamente norte-americano: o Western. Welcome to Hard Times (1960) conta a história de uma pequena comunidade do velho-oeste americano devastada por um forasteiro (simplesmente chamado de "Homem Mau de Bodie"), que, sem justificativa, mata, destrói e espalha terror pela vila de Hard Times. Os remanescentes do massacre reconstroem a vila e cultivam um desejo de vingança que resultará em novo ciclo de violência e destruição. Em um padrão de gradual desencantamento e desânimo que vai se repetir em outros romances - sobretudo em Homer \& Langley - o narrador chega a Hard Times cheio de esperanças pouco antes da trágica visita do "Homem Mau de Bodie", sobrevive ao massacre e promove a reconstrução do povoado, antes de nova decepção. Ele é vencido pelo cansaço e atribui a forças atávicas o padrão de violência e destruição contra o qual tentara lutar:

Quando resolvi rumar para o Oeste de carroção, era rapaz com certas expectativas, não sei bem quais, e pintei meu nome a alcatrão num grande rochedo junto à trilha do Missouri. Mas com o tempo as expectativas se desgastaram, assim como se apagou o nome daquela rocha, e aprendi que bastava sobreviver. Homens Maus de Bodie não eram bandidos comuns. Faziam parte da terra e não se podia enfrentá-los, assim como não se podia vencer a poeira e o granizo $^{11}$.

10 "Though characters resurface, stylistically Doctorow is a nomad, leaping from the formal prose of his 19th-century New York novel The Waterworks, to the jazz cadences of Ragtime, to Homer Collyer's wry, melancholy reflections. "I don't have a style, but the books do. Each demands its own method of presentation..." (In: CROWN, Sarah. EL Doctorow: "I don't have a style, but the books do". The Guardian, London, 23 de Janeiro de 2010, Culture, Books. Disponível em <http://www.guardian.co.uk/books/2010/jan/23/el-doctorow-homer-and-lamgley>. Acesso em : 01 de Junho de 2013) Tradução minha. Esse aspecto da obra de E. L. Doctorow foi apontado por vários estudiosos de sua obra, como Harter e Thompson, para quem "no two books by Doctorow resemble each other" (HARTER, Carol C., THOMPSON, James R. E. L. Doctorow. Boston: Twayne Publishers, 1990, p. 2).

${ }^{11}$ DOCTOROW, E. L. Tempos Difíceis. Rio de Janeiro: Record, S/D, p. 14. 
A noção de história como repetição ${ }^{12}$ elaborada por vários dos personagens de Doctorow já é esboçada pelo narrador do seu primeiro romance, como podemos ver na passagem a seguir:

Nada é jamais enterrado. A terra gira, nunca vai a parte alguma, nunca muda, só a esperança modifica como a manhã e a noite. Só as expectativas aumentam e entram em declínio. Por que é preciso haver promessa antes da destruição? Que mais eu poderia ter feito? Se eu não tivesse acreditado todos estariam vivos hoje em dia $^{13}$.

Esse romance traz, como vimos, alguns dos temas que reaparecerão nas obras posteriores e também já demonstra as qualidades literárias do texto de Doctorow. No entanto, trata-se de uma narrativa convencional, formalmente distante dos romances mais experimentais dos anos 70, que nos interessam aqui por seu engajamento crítico e consciente - no nível da forma - com os problemas de seu tempo.

Big as Life (1966) traz duas figuras humanas gigantescas que aparecem em Nova York e lá permanecem, imóveis, trazendo espanto e medo à cidade. Esse romance de ficção científica é a única obra de Doctorow esgotada e não reeditada, e é desejo do autor que ela assim permaneça ${ }^{14}$. O romance tenta construir uma alegoria da ascensão da direita ao poder e da instauração de um estado policialesco, que surge como resposta à iminência de catástrofe representada pelos alienígenas gigantes. Há problemas de construção nessa alegoria tão evidentes que, em entrevistas, Doctorow não consegue esconder o embaraço pela autoria de tal obra. Para Douglas Fowler, essa narrativa de ficção científica é "uma tentativa de imaginar os Estados Unidos sob o domínio da direita que não consegue produzir nem um alerta, nem uma profecia e nem uma sátira, embora traga elementos dos

\footnotetext{
${ }^{12}$ Essa noção aparece, de uma forma ou de outra, em quase todos os romances do autor, ainda que de maneira periférica. Ela ganha uma formulação mais clara e uma participação maior no enredo no romance Homer \& Langley, como veremos no Capítulo 3.

${ }^{13}$ Idem. p. 174.

${ }^{14}$ Em entrevista, Doctorow explica sua decisão de não autorizar novas edições de seu romance de ficção científica: "Inquestionavelmente, esse é o pior que já fiz. Penso em retornar ao livro e refazê-lo algum dia, mas a experiência toda foi tão infeliz, tanto a escrita quanto a publicação, que talvez eu nunca o faça." (In: FOWLER, Douglas. Understanding E. L. Doctorow. Columbia: University of South Carolina Press, 1992, p. 21) Tradução minha.
} 
três ${ }^{15}$ ". Por se tratar de um exercício de criação ficcional claramente falho, essa obra não nos interessa aqui.

Entre os dois romances iniciais e The Book of Daniel (1971) há uma surpreendente distância em termos de experimentação e complexidade formal ${ }^{16}$. O terceiro romance publicado por E. L. Doctorow foi também seu primeiro sucesso editorial. Finalista do National Book Award ${ }^{17}$, o romance atraiu a atenção da crítica pelo desafio formal que propõe e pela incursão em zona nebulosa do passado político americano. Esse romance anuncia algo que será uma constante na obra de Doctorow: a variação de forma e estilo, do mais experimental - como em Loon Lake (1980) - ao mais tradicional - como em The March (2005).

Em 1975, é publicado Ragtime, sem dúvida o romance mais conhecido e mais estudado do autor. Ele pode ser facilmente encontrado em português, em edição de bolso, o que é clara indicação de seu prestígio, dada a escassez de títulos traduzidos no mercado editorial brasileiro. The Book of Daniel, por exemplo, não está atualmente disponível em português, já que sua tradução encontra-se há muito esgotada.

Loon Lake é publicado em 1980 e traz uma continuação da pesquisa formal iniciada em The Book of Daniel. O cenário agora é o Estados Unidos da Grande Depressão (1930s), onde Joe, um jovem de família pobre, corre atrás do sonho americano em meio ao geral desconsolo trazido pela crise econômica. Logo ele percebe que esse sonho não está ao alcance de todos e que o sucesso depende de uma separação da massa humana falida para a qual o american dream é apenas uma promessa eternamente renovada:

I didn't want these mockeries to my own kinship of consciousness, with all the conquests of my life still to come. How could I hope or scheme however idly in a flophouse with a hundred others, a thousand others, a hundred thousand others where the dreams rise on the breath and dissolve one another in a precipitate element not your own - and you are trapped in it, a dark underwater kingdom

\footnotetext{
${ }^{15}$ FOWLER, Douglas. Understanding E. L. Doctorow. Columbia: University of South Carolina Press, 1992, p. 25.

${ }^{16} \mathrm{O}$ autor tem consciência da distância de maturidade entre os seus dois primeiros romances e os dois romances escritos na década de 70: "In a certain sense the book [Ragtime] was an act of exploration, to find out what it itself was about, I did that with Daniel, too. The first two books I was very calculating, and I think that was a mistake. I learned to trust the act of writing." (DOCTOROW. In: MORRIS, op. cit., p. 9).
}

${ }^{17}$ Prestigiosa premiação do mercado editorial norte-americano. http://www.nationalbook.org/ 
fed by springs of alcoholic piss and sweat, in which there live and swim the vilest phantoms of $\operatorname{God}^{18}$.

Joe caminha sozinho e se constitui em observador silencioso da terra devastada que encontra. Há, no seu silêncio e na sua solidão, uma espera pelo momento de decisão e por uma reação que não se realizará no romance:

I was alone in all of it, there was some faculty of being alone I was born with, in the noise of life and clatter of tenement war, my brain was alone in the silence of observation and perception and understanding, that true silence of waiting for conclusions, of waiting for everything to add up to a judgment, a decision, that silence worse than the silence of the deaf and dumb ${ }^{19}$.

Esse "silêncio pior que o silêncio dos surdos e dos mudos" é o silêncio de quem possui a percepção da injustiça e renuncia à ação revolucionária. É essa frustração de saber e não agir que esse romance tenta figurar. Joe vai acumulando lições da falência do sonho americano ao longo de sua jornada de aprendizado. Em convívio com um grupo de "freaks" que faz da própria deficiência mercadoria para sobreviver, Joe é marcado pela história de uma moça deficiente mental que é oferecida por alguns trocados a uma fila de homens. Em seu olhar e na vida desses "freaks" de estrada, Joe reconhece um desespero que ele percebe ser a metáfora de uma agonia coletiva:

There was a harmony of malformation and life that could only scare the shit out of you if you thought about it. The freaks read the papers and talked about Roosevelt, just like everyone else in the country.

But with all of that they lived invalid lives, as someone in the pain of constant hopeless bad health and so their dispositions were seldom sunny ${ }^{20}$.

Essas primeiras páginas do romance vão construindo uma expectativa de que Joe se torne uma espécie de herói proletário. Continuando sua peregrinação, Joe invade a

\footnotetext{
${ }^{18}$ DOCTOROW, E. L. Loon Lake. New York: Random House, 2007, p. 17.

${ }^{19}$ Idem. p. 5.

${ }^{20}$ Idem, p. 21.
} 
propriedade do milionário F. W. Bennet e quase é morto por cães de guarda. Recolhido e tratado pela família Bennet, ele começa a frequentar a casa e vai se integrando ao mundo dos Bennet. Depois de uma série de peripécias, Joe abandona o conforto da casa de seus padrinhos ricos e volta para o convívio de sua classe de origem. Vai trabalhar numa das fábricas de Bennet e lá desenvolve uma consciência da exploração do trabalho que o levará, já no final do romance, à ação:

And then I resolved not to think at all, if I couldn't think well of Clara, I'd turn my mind from her knowing I was racked, knowing I couldn't physically feel hope in this hammering noise. But I didn't have to try not to think, by the middle of the afternoon my bones were vibrating like tuning forks. And so it had me, Bennett Autobody, just where it wanted me and I was screwed to the machines taking their form a mile away in the big shed, those black cars composed bit by bit from our life and the gift of opposition of thumb and forefinger, those precious vehicles, each one a hearse $\mathrm{e}^{21}$.

O final do romance é surpreendentemente estranho, até inverossímil. Quando Joe é preso por suas ações de protesto, ele declara aos policiais que é filho de F. W. Bennet e lhes pede que liguem e confirmem a história com o empresário. Esse final brusco e enigmático - cujo alcance alegórico, se algum houver, me escapa - levou muitos críticos a apontarem um abandono do enredo por parte do autor. É como se, na ausência de um final para a história de Joe, o autor tivesse simplesmente terminado o livro com esse arremate repentino, imprevisível e pouco compreensível ${ }^{22}$. Há nessa falta de fechamento coerente para a narrativa de Joe uma dificuldade de figuração semelhante àquela presente

\footnotetext{
${ }^{21}$ Idem, p. 165.

${ }^{22}$ Em Andrew's Brain (2014), dois personagens discutem o final inusitado de The Adventures of Huckleberry Finn como uma falha de fechamento: "What do you think of the ending of Huckleberry Finn, Professor? It's a goddamn disaster, isn't it? Ruined the whole story for me. When Tom makes his late entrance, it's Twain throwin' in the towel, coming in with his trickster shtick to wrap things up and while he's at it to make the whole grand thing of Huck and Jim going down the river neither here nor there. I know a little bit about the cruelties of life and I'll tell you, this is a damn shame of an ending, Twain bein' in such a hurry to finish his tale any which way and so crap up what might have been a huge story for all time. Did you know, Bill, that he stopped work on that book for seven years before coming up with the ending? Sure I knew, that's what I'm sayin'. Couldn't work it out, and said, Damn it all, I'll just get this thing off my desk...". Entendo que algo parecido ocorra com Loon Lake, uma falha de fechamento que diz muito sobre os impasses que geraram essa dificuldade de elaboração narrativa.
} 
na aparição tardia da história de Vag em $U$. S. A, de John Dos Passos ${ }^{23}$. É tema certamente importante para futuras pesquisas.

Há, em Loon Lake, a intrusão de uma voz narrativa que transita entre a prosa e a poesia. Alguns temas políticos não incorporados ao enredo são ali aludidos de forma enigmática e não conectada à narrativa. É como se esse espaço fosse uma espécie de mural no qual temas não elaborados pudessem ser livremente aludidos, sem a necessidade de serem conectados a cadeias de sentido mais amplas. Vejamos dois exemplos desse tipo de alusão não-elaborativa:

Come with me Compute with me Computerized she prints out me Commingling with me she becomes me Coming she is coming is she Coming she is a comrade of mine Comrades come all over comrades Communists come upon communists Hi. $\mathrm{Hi}^{24}$.

comprising life F. W. Bennett undergoing review.

Shown in two instances twenty-five years apart of labor relations lacking compassion or flexible policy understanding workers' needs. His dramatization suggests life devoted almost entirely to selfish accumulation of wealth and ritual use thereof according to established patterns of utmost class. It is alleged he patronizes unsavory elements of society for his business gain. It is alleged that he is sexually exploitative. It is suggested he is at least unmoved by the violent death of another human attributable to his calculated negligence ${ }^{25}$.

\footnotetext{
${ }^{23 *}$ Vag remains a final, somewhat desperate, attempt to bring it all back home, to figure the continent in a kind of ur-character, the young man on the road. As such, Vag is a revealing symptom of one of the trilogy's unresolved stories. For Vag marks the return of Mac, the first character in the trilogy, as well as Joe and Ike and the other working stiffs with monosyllabic names who appear in the first half of U. S. A." (DENNIG, Michael. The Cultural Front - The Laboring of American Culture in the Twentieth Century. New York, London: Verso, 1997, p. 186).

${ }^{24}$ Idem, p. 13.

${ }^{25}$ Idem, p. 158.
} 
Esse é um romance que merece uma leitura mais atenta, coisa que não tentarei aqui pela decisão de concentrar a análise em romances que articulam conteúdos históricos a uma forma de contar histórias que dialoga com esses conteúdos.

A narrativa do belo romance autobiográfico World's Fair (1985) também se passa nos anos da Depressão. Misturadas às lembranças de infância do narrador Edgar, estão as percepções do garoto sobre o contexto político em que vive, desde o crescente antissemitismo que ele presencia nas ruas de Nova York até a crise financeira que atinge a casa dos Doctorow nos anos 30. A figura da criança politicamente consciente de seu mundo, tão presente em romances como The Book of Daniel, Ragtime e Billy Bathgate, é esboçada aqui com traços autobiográficos: "In my own consciousness I was not a child. When I was alone, not subject to the demands of the world, I had the opportunity to be the aware sentient being I knew myself to be ${ }^{26}$ ".

Como Daniel, o Menino de Ragtime e Billy, Edgar sabe ler as notícias ruins de seu tempo nas entrelinhas do cotidiano, como vemos na passagem a seguir:

I found out that my father had lost his store one morning when I met him at the breakfast table. He was cheerful. "How are you, young man," he said. He had brought home a radio that you didn't have to plug in. It worked on a battery. It was covered in alligator skin and had a leather carrying handle. It was like a small suitcase and you flicked the switch and it lit up on the dial just like a regular radio. You could carry it anywhere, to the beach or picnics, but I found it heavy. Then I noticed a cardboard box with many packets of needles and also a microphone, the kind used by radio stations, except that it wobbled on its base. And finally there was a pack of records in green envelopes. Some of them were old with grooves only on one side. "These are rare recordings by Caruso and Gigli," my father said. "If we hold on to them long enough they'll be valuable." While I ate my oatmeal he opened his newspaper. I saw the headlines. The other bad news was that France had fallen to Hitler $^{27}$.

\footnotetext{
${ }^{26}$ DOCTOROW, E. L. World's Fair. New York: Random House, 2007, p. 19.

${ }^{27}$ Idem. p. 217
} 
Em meio a digressões e descrições sobre os inusitados objetos trazidos pelo pai sinal inequívoco do declínio econômico da família - salta à consciência infantil a crueza de uma realidade que se impõe sombriamente em casa (e no país, por metonímia) - na situação financeira da família - e fora (no mundo, também por metonímia) - na tomada da França pelos nazistas.

O olhar para os anos 30 como contraponto político para o presente - que é central em The Book of Daniel - é retomado em vários trechos de World's Fair, o que confirma a inclinação de Doctorow para tal comparação. Vemos isso na passagem a seguir:

Dad liked to patronize street people. You would be walking along with him and he'd suddenly veer over to a pushcart, or stop to by a pamphlet from someone. He did that as a matter of principle. He idealized the little man. He had a political consciousness. He rode the train to Boston for a rally for Sacco and Vanzetti. He wanted to take me but Mom wouldn't let him. The case obsessed him. He brought home Upton Sinclair's novel about it - Boston - it was in two volumes. He was very much a man of his time. He devoured the papers. Maybe everyone was more radical in those days. Nowadays when people protest something, they're looked on as oddities $^{28}$.

Billy Bathgate (1989) traz a história de um jovem pobre que começa a prestar pequenos serviços para um grupo de gângsteres e vai gradualmente ganhando a confiança de Dutch Schultz, chefe do grupo. Sem grandes pretensões formais, esse romance se concentra no enredo, o que lhe garantiu uma boa recepção de público e crítica e uma adaptação para cinema ${ }^{29} \mathrm{em}$ um filme com grandes estrelas de Hollywood, como Dustin Hoffman, Nicole Kidman e Bruce Willis. Como nos dois romances anteriores, o cenário dessa narrativa também é os anos 30 .

Já em The Waterworks (1994) o cenário é a Nova York de 1871. A narrativa trata da busca do jornalista McIlvaine por seu repórter Martin Pemberton, mas o grande tema do romance é a cidade. Durante suas andanças por Manhattan, o narrador McIlvaine descreve a cidade, seus costumes e seus habitantes. Estamos no tempo de William Magear Tweed (conhecido como "boss" Tweed) e da rede de corrupção com que controlava a

\footnotetext{
${ }^{28}$ Idem. p. 136.

${ }^{29}$ Billy Bathgate: O Mundo a Seus Pés (1991), dirigido por Robert Benton. Título original: "Billy Bathgate".
} 
cidade. O reservatório de água que existia onde hoje estão a New York Public Library e o Bryant Park é descrito com o encanto de uma reconstituição histórica elegante e precisa. Por meio do olhar perscrutador do jornalista Mcllvaine, mergulhamos na Nova York do final do século XIX, onde a degeneração e a corrupção convivem com os avanços tecnológicos e a crença no progresso. No entanto, a presença da história nesse romance é mais cenográfica do que motora do enredo.

Nova York é cenário de quase todos os romances de Doctorow. Em The Waterworks a cidade é visitada com a curiosidade e o encanto de quem admira e conhece essa megalópole. Há nas descrições do narrador um sabor do pitoresco de um cartãopostal.

Se o mistério do sumiço de um personagem desencadeia, em The Waterworks, uma série de descrições da vida em Nova York no ano de 1871, em City of God (2000) é o sumiço de uma grande cruz do altar de uma igreja episcopal do Lower East Side e seu reaparecimento em uma sinagoga do Upper West Side que lança um romancista em uma investigação da qual derivarão inúmeros fragmentos filosóficos ${ }^{30}$. O foco da investigação desse "detetive teológico" é menos o caso da cruz e mais a "crise metafísica que nos perturba $^{31 "}$. Sua busca é pela "verdade", ao menos a verdade metafísica da religião:

Então onde se deve encontrar a verdade? O ecumenismo é politicamente correto, mas qual é a questão? Se a fé é válida em todas as suas formas, estamos meramente fazendo uma escolha estética quando escolhemos Jesus ${ }^{32}$ ?

\footnotetext{
${ }^{30}$ Estes são alguns dos objetos de especulação filosófica no romance: Nova York (pp. 16-18 e 315), Canções (pp 39, 53 e 256), "Me and my shadow" (p. 31), "Star Dust" (p. 960), "Good Night Sweetheart" (p.146), "Dancing in the Dark" (p. 204), "The song is you" (p. 287), Holocausto (pp. 66 e 71), Gueto de Kovno (p. 191), Corvos nas docas (p. 70), Martim-pescador-de-coleira (p. 110), Filhotes de falão-peregrino (p. 238), Formigas (pp. 311 e 312), Contadores de histórias (pp. 87 e 88), Consciência solipsística (p. 165), Detetive teológico (pp. 25, 119, 195 e 260), História da Igreja católica - história do poder - Jesus político (p. 95), Textos bíblicos - hermenêutica (p. 151), Razão e fé (p. 212), Existência do nada (p. 31), Planeta terra (p. 109), Fundo do mar (pp. 139 e 140), Noé - massa pós-diluviana (pp. 182 e183), 60s (pp. 210 e 213), Cinema (pp. 275, 276, 277 e 331), Cidade de Deus (pp. 286, 287 e 310), Cidade moderna (pp. 347 e 348). (Deus, um fracasso amoroso. São Paulo, Rio de Janeiro: Editora Record, 2003).

${ }^{31}$ Idem. p. 83.

${ }^{32}$ Idem. p. 22.
} 
Personagens reais como Ludwig Wittgenstein e Albert Einstein aparecem no enredo como vozes questionadoras das certezas que o romancista "detetive teológico" procura. Einstein, por exemplo, fala sobre o universo criado por Deus, que ele chama de "O Velho": "Portanto: afinal, podemos com segurança dizer somente o seguinte sobre o universo do Velho: que nada é constante além da velocidade da luz ${ }^{33}$ ".

Esse estranho romance por vezes parece transitar entre o ficcional e o ensaístico. Os romances de Doctorow trazem sempre alguns fragmentos filosóficos, mas em City of God eles parecem se sobressair à narrativa. Fenômeno parecido se dá com os contos do autor. Muitos deles parecem mais ensaios do que narrativas. É claro que um estudo detalhado desses textos exigiria uma reflexão sobre os limites entre esses dois gêneros, coisa que não pretendo fazer aqui.

Romances formalmente indefinidos como Loon Lake e City of God deixam rastros visíveis da pesquisa formal que torna Doctorow um autor de grande relevância para a crítica literária interessada no alcance cognitivo do romance. Além da inegável qualidade literária desses livros, sua leitura também possibilita a compreensão dos rumos possíveis dessa forma literária hoje.

Em The March (2005), Doctorow retorna ao século XIX para tratar da Guerra Civil Americana. O romance traz várias narrativas de personagens (alguns deles históricos) que acompanham ou são afetados pela Marcha do general William Tecumseh Sherman para leste. A marcha, que reuniu mais de 60 mil homens, começa em 1864 em Atlanta - incendiada por Sherman - e segue por três estados (Georgia, Carolina do Sul e Carolina do Norte) em direção ao litoral.

Em Ragtime e The Book of Daniel os fatos históricos são modificados em favor da ficção. Não há, nesses livros, um rigor historiográfico na representação do passado, fato que - como veremos no Capítulo 2 - tem gerado críticas e polêmicas. O mesmo não acontece em romances como The Waterworks e The March. Theophilus Savvas, comparando The March aos romances mais experimentais de Doctorow, nota nele uma recusa, no nível da forma, ao "impulso metaficcional” (marca das obras aqui estudadas), ainda que o livro preserve o conteúdo historiográfico, presente em quase toda a obra de Doctorow, com poucas exceções, como o romance World's Fair e alguns contos. Diz o

\footnotetext{
${ }^{33}$ Idem. p. 52.
} 
crítico: “...where The Book of Daniel and Ragtime are examples of that archetypal postmodernist form, historiographic metafiction, The March, for all its historiographic content, finally refuses, at the level of form, the metafictional impulse ${ }^{34}$.

O rigor da reconstituição histórica nesse romance pode ser medido pelos agradecimentos, ao final do livro, a especialistas no período retratado consultados pelo autor, pela utilização do romance como leitura em cursos de História da Guerra Civil Americana ${ }^{35}$ e pelas inúmeras apresentações do livro em sociedades historiográficas nos Estados Unidos.

Enquanto em Ragtime o tratamento dado aos personagens históricos é irreverente, por vezes jocoso, em The March eles são tratados com respeito (como no caso dos generais Sherman e Grant) e até veneração, como podemos ver na passagem a seguir, sobre o presidente Abraham Lincoln:

Wrede lingered on the dock. The moral capacity of the President made it difficult to be in his company. To explain how bad he looked, the public care on his brow, you would have to account for more than an inherited syndrome. A proper diagnosis was not in the realm of science. His affliction might, after all, be the wounds of the war he'd gathered into himself, the amassed miseries of this torn-apart country made incarnate.

Wrede, who had attended every kind of battle death, could not recall having ever before felt this sad for another human being. He stood on the dock, not wanting to go on board. Life seemed to him terribly ominous at this moment ${ }^{36}$.

O tema da representação da história como uma construção sujeita a manipulação é recorrente nos romances de Doctorow. Em Ragtime, como veremos, esse tema é constitutivo do romance. Já The March parece se engajar em uma noção mais elementar da história como fonte de lições para o presente. O personagem Albion é ferido na cabeça e sofre um dano cerebral que o impede de guardar memórias. Ele só preserva a faculdade da linguagem e vive de instante em instante, em um eterno presente:

\footnotetext{
${ }^{34}$ American Postmodernist Fiction and the Past. London: Palgrave Macmillan, 2011, p. 152.

${ }^{35} \mathrm{O}$ romance é adotado como bibliografia sobre a Guerra Civil Americana, por exemplo, no curso The Civil War and Reconstruction Era, 1845-1877, da Universidade de Yale. http://oyc.yale.edu/history/hist-119\#syllabus

${ }^{36}$ DOCTOROW, E. L. The March. New York: Random House, 2006, p. 355.
} 
I have forgotten yesterday. My head hurts. What is this that hurts? Your head. You said your head hurts.

It does. I can't remember. I say a word and I can't remember it. What did I say I can't remember?

A word.

Yes. That is why my head hurts. It's always now. That's what hurts. Who did you say I was?

Albion Simms.

No, I can't remember. There is no remembering. It's always now. Are you crying?

Yes. Because it's always now. What did I just say?

It's always now.

Yes.

Albion, in tears, held his bar and nodded. Then he rocked himself back and forth, back and forth. It's always now, he said. It's always now ${ }^{37}$.

Incapaz de lembrar, Albion se suicida empurrando para dentro do cérebro a barra que ele carregava no crânio e que não podia ser removida sem perigo de morte.

A guerra é retratada no romance com rigor pictórico. Há cenas de batalha banhadas de sangue. Há feridos e muitos mortos. Há cenas de execução. A Marcha de Sherman é retratada como uma máquina de guerra animalesca, impiedosa e irracional:

I don't know what to think. I've lost everything to this war. And I see steadfastness not in the rooted mansions of a city but in what has no roots, what is itinerant. A floating world.

It dominates, Wrede said.

Yes.

And in its midst you are secure.

Yes, Emily whispered, (...)

But supposing we are more a nonhuman form of life. Imagine a great segmented body moving in contractions and dilations at a rate of twelve or fifteen miles a day, a creature of a hundred thousand feet. It is tubular in its being and tentacled to the roads and bridges over which it travels. It sends out as antennae its men on horses. It consumes everything in its path. It is an immense organism, this army, with a small brain. That would be General Sherman, whom I have never seen ${ }^{38}$.

\footnotetext{
${ }^{37}$ Idem. p. 274.

${ }^{38}$ Idem. p. 61.
} 
Esse é um romance sobre a guerra. Em narração convencional, por vezes emotiva e mesmo sentimental, ele trata de um dos conflitos mais sangrentos e traumáticos da história americana:

What war was fought more bitterly and with more fervor and intensity than a civil war? No war between nations could match it. The generals of the North and South knew one another-they had been at West Point together or served side by side in the Mexican War. England, of course, had a great and bloody history of civil wars, but they were ancient matters to be studied in public school. This in America was to be seen with one's own eyes. And as bloody and brutal were the contests of Lancaster and York, they were hand to hand-battle-axes, pikes, maces. These chaps were industrialage killers: they had repeating rifles that could kill at a thousand yards, grape that could decimate an advancing line, cannon, fieldpieces, munitions that could bring down entire cities. Their war was so impersonally murderous as to make quaint anything that had gone on before ${ }^{39}$.

Os três romances de Doctorow cujos enredos se situam no século XIX (Welcome to Hard Times, The Waterworks e The March) adotam formas de narrar convencionais. Já os romances formalmente ousados (The Book of Daniel, Ragtime, Loon Lake, City of God) se passam, todos, no século XX. Essa relação entre história e forma estará presente nas análises que se seguem. Ela se pronuncia de maneira mais evidente em The Book of Daniel, romance no qual tempos confusos e conturbados se traduzem na dificuldade do narrador de interpretar os fatos que observa e de ordená-los de maneira coerente.

Já em Homer \& Langley (2009) temos uma narrativa convencional em que fatos do século XX vão se intrometendo na vida dos dois protagonistas. A disposição cronológica dos fatos históricos na narrativa cria um efeito de retrospectiva do século que nos interessa pelo potencial de mapeamento e retomada de temas tratados em outros romances de Doctorow.

O mais recente romance de Doctorow foi publicado há poucos dias. Andrew's Brain traz um longo diálogo entre Andrew, um cientista cognitivo que carrega o fado de

\footnotetext{
${ }^{39}$ Idem. p. 214.
} 
“deixar desastres por seu caminho ${ }^{40 "}$, e um psiquiatra. Os fatos da vida de Andrew vão se revelando ao leitor a medida que são apresentados ao médico. Sabemos que Andrew teve três filhos: o primeiro nasceu morto em um aborto espontâneo; o segundo é acidentalmente morto por Andrew, que administrou o medicamento errado ao bebê; o último é dado à ex-mulher de Andrew, a mãe do filho por cuja morte ele fora responsável. Há implicações alegóricas nessas mortes e nesse abandono que não temos espaço para explorar aqui.

Ao longo do romance, uma alegoria política vai se revelando por meio da exposição dos dramas psicológicos de Andrew. Há uma aproximação entre o comportamento de Andrew e o de seu país que só se estabelece com mais clareza no terço final do romance. $\mathrm{O}$ trecho a seguir, quando relido à luz das revelações que são feitas ao final da narrativa, ganha conotações políticas não sugeridas na primeira parte do livro:

Because the truth is, I just shrug and soldier on. As kind as I am, as well-meaning and helpful as I try to be, I have no feelings finally, for good or ill. In the depths of my being, no matter what happens, I am left cold, impenetrable to remorse, to grief, to happiness, though I can pretend well enough even to the point of fooling myself. I am trying to say I am finally, terribly, unfeeling. My soul resides in a still, deep, beautiful, emotionless, calm cold pond of silence. But I am not fooled. A killer is what I am. And to top things off I am incapable of punishing myself, taking my own life in despair of the wreck I've made of people's lives, helpless infants or women I love ${ }^{41}$.

Memória ${ }^{42}$ e impossibilidade de sentir culpa são temas recorrentes na longa sessão de análise que constitui o enredo desse romance. Andrew fala de sua insensibilidade:

There is a caesura in my brain - so that honor, among other virtues, is nothing I connect to. I have none. Deep down, at the bottom of my soul, if such exists, I am finally unmoved by what I've done. A faint tinge of regret for dead babies, for dead wives,

\footnotetext{
40 "I couldn't know in advance how to avoid disaster, as if no matter what I did something terrible would follow." (DOCTOROW, E. L. Andrew's Brain. New York: Random House, 2014).

${ }^{41}$ Idem. Não há indicação de páginas na versão para Kindle de onde as citações foram extraídas.

${ }^{42}$ Andrew é um cientista cognitivo que pesquisa a existência de uma memória genética que todo ser humano carrega: "The genome of every human cell has memory. You know what that means? As evolved beings we have in our genes memories of the far past, of long-ago generations, memories of experiences not our own." As conotações políticas dessa memória vão se relevando ao longo da leitura do romance.
} 
for the fires I've inadvertently started, and all such disasters can make me run in my dreams to someplace where I can't do any harm, but in this waking life I am numb to my guilt ${ }^{43}$.

A insensibilidade de Andrew é relacionada, na alegoria política elaborada no romance, à letargia dos americanos diante dos problemas do mundo. Depois de matar acidentalmente seu filho, Andrew é abandonado pela primeira esposa e assume um cargo de professor em uma cidade do interior dos Estados Unidos. Lá ele começa a namorar sua aluna Briony, que será sua segunda esposa, mãe de seu único filho que permanecerá vivo e a grande paixão de sua vida. Em diálogo com ela, Andrew diz:

We discussed the possibility that Americans more than any other people understand what the earth and sky have to offer. At these moments life was what it was and nothing more, it was exactly what it seemed to be with nothing behind it. A presiding belief in the future, all the synapses afire as if to make a metaphysical music and you are blissfully existing in the consciousness of the customary given world as the only reality. And of course the guilt is gone ${ }^{44}$.

A pacata vida de classe média que Andrew busca na cidadezinha americana entre montanhas é mencionada novamente como pacificadora de conflitos no trecho a seguir:

You remember why the great Heinrich von Kleist committed suicide? He'd read Kant, who said we could never know reality. He should have come out west, Heinrich. Would have saved his life. No despair of intellect possible in these parts. Something about the mountains and the sky. Something about the football team ${ }^{45}$.

Uma sombra de intranquilidade paira sobre a narrativa. Sabemos que Andrew escuta vozes silenciosas (“soundless voices ${ }^{46 ”)}$. Esse fato é mencionado ao longo da

\footnotetext{
${ }^{43}$ Idem.

${ }^{44}$ Idem.

${ }^{45}$ Idem.

46 "I find myself reluctant to tell you that I hear the soundless voices too when I'm up and about in my daily life." (Idem) O significado político dessas vozes será revelado no último terço do romance. No final da narrativa, Andrew volta a falar das vozes, mas agora o leitor sabe a quem elas pertencem: "My mind is shot through with visions, dreams, and the actions and words of people I don't know. I hear soundless voices, phantoms loom up out of my sleep and onto the
} 
narrativa, mas só saberemos que vozes são essas a partir de revelações que serão feitas no último terço do livro.

Com Briony, Andrew encontra paz e o enfraquecimento de sua insensibilidade. Ele se importa com ela e com a filha que terão. Eles se mudam para Nova York, onde nasce a filha do casal. Andrew descreve o cotidiano da feliz família na cidade, a maneira como vizinhos e comerciantes locais adoram Briony, a expectativa de todos na vizinhança pelo nascimento da filha dos dois, o primeiro passeio com o bebê e a festiva recepção que encontram por onde passam. Sabemos, também, que Briony - atleta na faculdade - decide correr a Maratona de Nova York. Ela treina todos os dias, correndo do West Village, onde moram, até Lower Manhattan. Andrew nos informa também que Briony frequentemente encerra seu treinamento com um treino de resistência, que ela executa subindo as escadas de algum edifício alto. O World Trade Center é destino frequente de Briony nessas sessões de treino. A aparição da sigla WTC na narrativa, com toda a carga simbólica e traumática que leva ${ }^{47}$, traz o peso de uma revelação. A partir daí, o leitor pode intuir o que acontecerá.

Dirk, amigo e ex-namorado de Briony, muda-se para Nova York e vai trabalhar em Lower Manhattan. Um dia, ele e Briony combinam um almoço. No dia marcado, Briony se despede do marido e da filha e parte para o seu treino diário, após o qual ela encontrará Dirk. Andrew percebe uma mensagem na secretária eletrônica. É Dirk. Ele está preso em uma das Torres e preste a se lançar pela janela. A mensagem é longa e dramática e termina assim:

And then I heard the flame behind him like a whoosh of a monstrous breath and think now, as I have listened to the point where I don't have to listen to hear it, I hear too the voices of the others on the ninety-fifth floor with him as they burned to death,

wall, lingering there, cringing in anguish, curling up in visible contortions of pain and crying out wordlessly for my help." (Idem).

${ }^{47}$ Lembremos que esse trauma demorou um tempo para ser elaborado em forma de narrativa. Parecia haver uma dificuldade em lidar com o fato que limitava a imaginação criativa. Um episódio é significativo dessa dificuldade: após da destruição das Torres Gêmeas, o lançamento do filme Spider Man foi adiado para que uma cena na qual o Homem-Aranha tece uma teia entre as torres do WTC fosse retirada do filme. Por algum tempo, imagens e menções às Torres eram tratadas com hesitação. Doctorow, que viveu a vida inteira em Nova York e cuja relação com a cidade é visível em sua obra (praticamente todos os romances escritos por ele se passam nessa cidade, cuja importância nessas narrativas é grande) publicou dois romances depois de 2001 (The March, em 2005 e Homer \& Langley, em 2009) e só foi abordar o 11 de Setembro no romance publicado agora em 2014. 
their cries the last organic traces of their enflamed bones, a weird awful chorus finally indistinguishable from the roar of the oil fire and the cringe and screech and squeak of the tortured steel and from the oily smoke of flames that refueled from the smoke and blew out again to flame. And then I hear air in its resistance to a falling body, it is like the sound of a jet engine louder and louder in higher and higher pitch and it lasts but a few seconds before it ceases to be sound, before I hear only the absence of sound followed ...

Vemos aqui a fusão das duas imagens mais recorrentes nas narrativas sobre o 11 de Setembro: "the falling man" (O homem-em-queda) e a dramática mensagem final na secretária eletrônica ${ }^{48}$.

A partir daí desse ponto, a narrativa passa a tratar abertamente de eventos políticos que marcam a história dos Estados Unidos no começo do século XXI. Andrew, que sempre se declarou consciente da história recente de seu país ${ }^{49}$, passa a observar essa história de camarote: de dentro do salão oval da Casa Branca.

Depois da morte de Briony, Andrew deixa a filha do casal com sua primeira esposa e segue para Washington, onde assume um posto de professor de ciências em uma escola pública. Um dia, sua aula é interrompida por um tumulto e a entrada do Presidente dos Estados Unidos, que o reconhece imediatamente. Eles haviam sido colegas de quarto em Yale. O presidente convida Andrew a assumir o cargo de diretor do "Departamento de Pesquisas Neurológicas da Casa Branca ${ }^{50}$ ".

O romance não nomeia Bush, mas todas as informações e descrições dadas por Andrew (a começar pela formação em Yale) coincidem com os fatos sobre esse

\footnotetext{
${ }^{48}$ Dois exemplos de narrativas sobre os ataques de 11 de setembro de 2001 que usam essas imagens: os romances "The Falling Man" (2007), de Don Delillo e "Extremely Loud and Incredibly Close” (2005), de Jonathan Safran Foer.

49 "I've always responded to the history of my times. I've always attended to the context of my life. The context. Yes, as it ripples in concentric circles all the way out to the stars." / "I am politically informed, Doc. Apart from everything I've been telling you about myself, I am a citizen sensitive to his country's history." (Idem).

50 Andrew explica a função do seu departamento: "This will involve tracking neurological developments around the world and eventually putting together a commission of cognitive scientists to formulate brain research policy. Don't you believe it's important for the government to predict how people will react to various stimuli, foreigners especially? Or to magnetically image the hallucinogenic mind? Or how to manipulate the brain's plasticity? Or a hundred other mental issues that can be useful to a government?".
} 
presidente $^{51}$ (sobretudo com a imagem que muitos americanos - e muito mais gente fora dos Estados Unidos - têm de George Walker Bush). Vejamos alguns exemplos de atos e características do presidente no romance que fazem lembrar Bush:

Who am I to blame anyone for anything? But he was feckless, irresponsible, in over his head.... I believed he'd brought a fatal lassitude to the federal mind. On the theory that the president we get is the country we get. That was worth looking into, don't you think?

I'd be at my desk cramming for an exam and he couldn't bear that, he'd drag me off to a bar.

And every once in a while, after a few beers, what came to the fore was his mean streak, because he did have one. [thinking] His fooling around could segue into hurting people. Or humiliating them. His grades were dismal, he never cracked a book.

I can tell you my roommate and I smoked dope in the upstairs of a huge floor-length duplex and not a book in sight.

$*$

Later, when I was sitting around in the Oval Office, I recognized the same twist of the mouth before the punch line of some dumb joke. That was the same. And the cockiness was there.

$*$

But my old buddy would want me to have coffee just to sit around and talk about anything except being president. His war was not going well. He'd invaded the wrong country. You can't imagine the anxiety that produces.

In their eyes the president was a kind of dauphin who they felt lacked gravitas, to say nothing of a reasonable attention span.

\footnotetext{
${ }^{51}$ Suspeito que Doctorow tenha optado por não usar os nomes reais dos personagens ainda vivos por questões legais. Há, na primeira página do romance, uma mensagem que aponta para essa hipótese: "Andrew's Brain is a work of fiction. All incidents and dialogue, and all characters with the exception of some well-known historical and public figures, are products of the author's imagination and are not to be construed as real. Where real-life historical or public figures appear, the situations, incidents, and dialogues concerning those persons are entirely fictional and are not intended to depict actual events or to change the entirely fictional nature of the work. In all other respects, any resemblance to persons living or dead is entirely coincidental." Tal mensagem não aparece em nenhum outro romance do autor.
} 
I had begun to feel sorry for my old roommate. He lived with his ineptitude.

O Presidente é reiteradamente descrito como um fantoche nas mãos dos verdadeiros comandantes do país ${ }^{52}$ : Chaingang (Dick Cheney) e Rumbum (Donald Rumsfeld), que recebem esses apelidos, no romance, do próprio Bush.

A caracterização negativa do Presidente é complementada por informações sobre a maneira como ele foi eleito, sobre sua inércia na prevenção dos eventos de 11 de Setembro $^{53}$, sobre os antigos vínculos da família Bush com a indústria do petróleo ${ }^{54} \mathrm{e}$ sobre o "aluguel" do quarto que pertenceu a Abraham Lincoln na Casa Branca para ricos doadores de campanha.

O caráter jocoso e irresponsável do Presidente se mostra até na ida de Andrew para a Casa Branca: sua contratação foi motivada pelo desejo do "Líder do Mundo Livre" de pregar uma peça em Chaingang e Rumbum:

So his next joke was to announce that I was a brain researcher doing a study of executive brains like theirs. They were busy men, they had things to do, a war to run, and here he was having fun at their expense. Your brains are looking good, he told them. Like a promising field for oil drilling ${ }^{55}$.

\footnotetext{
52 "The two key men in his administration, the ones who ran things, were Chaingang and Rumbum." / "Chaingang and Rumbum were self-appointed world strategists. They had ranks of ideologues and think-tank warriors behind them. The president was only that." / "The president had his hands full with Chaingang and Rumbum, men he'd appointed who had more or less taken over where the important decisions were to be made." (Idem).

53 "My roommate had gotten where he was by not quite the usual elected way. I knew how things had gone since-his chosen war, his anti-scientism. I knew all about him and the quality of the people around him. [thinking] Analyses had been done. All you had to do was read the newspaper. Those flights should never have happened. The intelligence was there." (Idem).

${ }^{54}$ Durante as férias escolares, Andrew acompanha seu amigo famoso à casa da família e lá participa de um jantar promovido para amigos: "It was a colorful dinner, in fact, all these sheiks and princes in their keffiyehs and designer floor-length tunics, men without women, mustached, bearded, stately, impressive, and in fact dressed appropriately in cotton for this desert." (Idem).

${ }^{55}$ Idem.
} 
Andrew perdeu a mulher que amava nos atentados de 11 de Setembro de 2001. Ele acredita que o Presidente poderia ter evitado os ataques. Presencia o comportamento brincalhão e pouco interessado com que Bush trata o governo. Presencia o jogo de interesses pessoais que motiva as ações de Chaingang e Rumbum, verdadeiros governantes do país. A partir disso tudo, poderíamos esperar de Andrew alguma reação a esse estado de coisas. Ela acontece, primeiro na forma de um discurso:

How insulated these men were. They were imperial in their selfhood, these corporate culturists running a government. They lived, heedless, infallible. They understood contention and expected nothing else. I told them it depressed me to be in the same room with them. The president looked at me-did I mean him as well? You all live unquestioningly inside the social reality — war, God, money - that other people invented long ago, I said, and you take these things for raw existence. It was quite a speech I gave them ${ }^{56}$.

Andrew coroa seu discurso "plantando bananeira" no Salão Oval da Casa Branca diante do Presidente, do Vice-presidente e do Secretário de Defesa. O gesto tolo é comentado por Andrew:

But it was more than that. I doubt if anyone had ever done a handstand in the Oval Office before. Really it was a triumph. I had for a moment risen out of my characteristic humility, my ordinary citizenness, and in one upside-down gesture achieved equity with these governors of my country.

Cinicamente, Andrew se iguala, com essa ação, ao grau de tolice dos governantes de seu país. Nessa equivalência de atos sem sentido se expressa o descrédito do poder e uma falha de mapeamento cognitivo. Matar os três mudaria algo? Sequestrá-los e exigir mudanças na condução de seu país seria viável? Denunciar o que acontece no Salão Oval traria alguma mudança? O gesto estéril de "plantar bananeira" é a imagem do ceticismo.

No entanto, tal ato é tratado como uma ameaça à segurança nacional. Andrew é detido, levado para uma prisão fora do país e o longo diálogo que constitui a narração no romance é, agora sabemos, parte do interrogatório/análise ao qual ele é submetido pelo psiquiatra do governo.

\footnotetext{
${ }^{56}$ Idem.
} 
A obviedade da crítica ao governo Bush e o tom agressivamente jocoso com que o presidente é tratado no romance lembra mais Michael Moore do que o Doctorow de The Book of Daniel. Assim, para os leitores entusiasmados de Ragtime e The Book of Daniel, o mais recente romance de Doctorow pode ser um experiência de leitura decepcionante.

A apresentação dos romances acima mostrou que a variação de formas é uma constante na obra de Doctorow. Os três romances que escolhi para análise na tese são representativos da obra desse autor e do romance histórico contemporâneo.

Muitos dos romances de Doctorow poderiam ser chamados de "romances históricos 57 ". Escolhi aqueles que melhor problematizam essa forma na contemporaneidade, sobretudo Ragtime.

Além do critério forma, utilizei um recorte temporal para selecionar esses três romances: todos eles tratam de eventos ocorridos no século XX e, juntos, traçam um panorama do século.

Um critério relacionado ao anterior é a mapeamento das formas de pensamento radical nos Estados Unidos no século passado: dos socialistas e anarquistas de Ragtime, passando pela Velha esquerda dos anos 30, a Nova esquerda dos anos 60 em The Book of Daniel até os hippies e as formas de pessimismo e descrença na ação política que vieram se desenhando ao longo do século e que se consolidam nos anos 80 , como veremos em Homer \& Langley.

A pesquisa formal de Doctorow tem seus melhores resultados nos seus dois romances da década de 70: The Book of Daniel e Ragtime. Os capítulos 1 e 2 tratarão desses romances, procurando evidenciar a relação entre forma e história nesses textos.

Essas duas obras também são centrais nas discussões sobre a forma do romance histórico na contemporaneidade. Essa discussão será analisada no capítulo 2 à luz de uma análise detalhada de Ragtime, que apontará pontos positivos e negativos das várias posições críticas adotadas em relação a esse romance.

\footnotetext{
${ }^{57}$ Essa possibilidade de classificação dos romances será vista na primeira parte do capítulo 2 .
} 
No capítulo 3, veremos como o romance Homer \& Langley elabora uma espécie de súmula de vários temas históricos presentes na obra de Doctorow. As guerras, que compõem os cenários dos outros romances, aparecem aqui num mesmo quadro histórico. Fredric Jameson notou que, vistos em conjunto, os romance de Doctorow parecem delinear um panorama do século $\mathrm{XX}^{58}$. Em Homer \& Langley, esse projeto, implícito na obra, se torna visível.

Estudaremos essa obra também como exemplar dos rumos contemporâneos do romance histórico. Se observarmos a obra de Doctorow, notaremos que ela atinge um pico de experimentação formal na década de 70, com os dois romances aqui analisados, e, a partir daí, retorna a formas de narrar mais convencionais.

Loon Lake, de 1980, é o último romance formalmente ousado de Doctorow antes dessa virada em direção à narrativa mais convencional. É, como mencionei, um experimento mal resolvido, com vozes narrativas desconexas do todo e um final abrupto.

A partir daí, temos sete narrativas ${ }^{59}$ bem mais convencionais (em graus variados) do que os dois romances da década de 70. Esse retorno a formas menos ousadas de contar histórias parece ser uma tendência da literatura a partir da década de $80^{60}$, que a obra de Doctorow acompanha.

Nos três capítulos de análise que se seguem, mostrarei a inter-relação entre história e forma nos romances históricos sobre o século XX desse grande escritor americano visando uma contribuição nas discussões sobre os rumos desse gênero romanesco na contemporaneidade.

\footnotetext{
${ }^{58}$ Pós-Modernismo - A lógica Cultural do Capitalismo Tardio. São Paulo: Ática, 1996, p. 48.

${ }^{59}$ World's Fair (1985), Billy Bathgate (1989), The Waterworks (1994), City of God (2000), The March (2005), Homer \& Langley (2009) e Andrew's Brain (2014).

${ }^{60} \mathrm{Um}$ resumo dessa tendência é dado por Robert Eaglestone: "First, there is retreat from the extreme playfulness of postmodernism and the emphasis on textuality and on difficulty. But, crucially, this retreat is not a simple reaction against and rejection of all the techniques of postmodernism, but rather a gentler, more accessible version of them, with a strong interest in telling a story. (...) Still, if the word 'post-postmodernism' wasn't too silly in itself, it wouldn't be accurate precisely because, while these writers have clearly learned a great deal from the experimentalism of postmodernism and its forebears, they have integrated it, domesticated it, and returned some way to the more traditional forms of the novel." (EAGLESTONE, Robert. Contemporary Fiction. Oxford: Oxford University Press, 2013, pp. 14-15).
} 


\section{Capítulo 1}

\section{"The novel as a sequence of analyses": a forma possível e as possibilidades da forma em The Book of Daniel.}

Os homens fazem sua própria história, mas não a fazem como querem; não a fazem sob circunstâncias de sua própria escolha e sim sob aquelas com que se defrontam diretamente, legadas e transmitidas pelo passado. (Karl Marx. O 18 Brumário).

How to write chapters of a phenomenology when there is no longer any possibility of a whole? How to analyze the part as a part when the whole is not only no longer visible but even

inconceivable? How to continue to use the terms subject and object as opposites which presuppose, in order to be meaningful, some possible synthesis, when there is no synthesis even imaginable, let alone present anywhere in concrete experience? What language to use to describe an alienated language, to what systems of reference to appeal when all systems of reference have been assimilated into the dominant system itself? How to see phenomena in the light of history, when the very movement and direction that gave history its meaning seem to have been swallowed up in sand? For the

fundamental formal problem of the dialectical writer is precisely that of continuity. (JAMESON, Fredric. Marxism and

Form, p. 50)

Visito os fatos, não te encontro. Onde te ocultas, precária sintese, penhor de meu sono, luz dormindo acesa na varanda? Miúdas certezas de empréstimo, nenhum beijo

sobe ao ombro para contar-me a cidade dos homens completos.

(Carlos Drummond de Andrade, Nosso Tempo) 


\section{Histeria e perseguição: os Rosenberg e a Guerra Fria}

Inspirado no caso Rosenberg - notório julgamento em que o casal de militantes de esquerda Julius e Ethel Rosenberg foi condenado à pena de morte pela acusação de ter conspirado para roubar o segredo da bomba atômica e tê-lo entregue aos Russos ${ }^{61}-$ The Book of Daniel conta a história do julgamento e execução do casal Paul e Rochelle Isaacson - versão ficcional dos Rosenberg - a partir do ponto de vista de Daniel Isaacson, filho do casal e aluno de pós-graduação da Universidade de Colúmbia. A história que lemos é escrita por Daniel, na biblioteca da universidade, enquanto ele mistura trechos de suas leituras a lembranças de família e reflexões diversas sobre os fatos narrados, ocupando o espaço de uma tese de doutorado com algo bem diverso do que se tem por obra acadêmica. O romance que é escrito no lugar da tese é oferecido ao leitor como testemunho de uma vida marcada por acontecimentos cruciais da história da Esquerda americana no século XX, vividos e narrados por Daniel, como os conflitos de Peekskill, o Macarthismo, o surgimento da Nova Esquerda nos campi universitários americanos, a Marcha ao Pentágono em protesto à Guerra do Vietnam etc... Nas linhas finais do romance, Daniel encerra sua narrativa ironicamente evocando - por meio de fórmula de apresentação de teses - o trabalho acadêmico o qual se perdeu no emaranhado de lembranças, ensaios e reflexões que resultaram no "Livro de Daniel":

\footnotetext{
${ }^{61}$ Vários livros foram escritos sobre o caso e os posicionamentos a respeito do veredito variam com o contexto histórico. A partir dos anos 70, com o acesso a documentos sigilosos sobre o julgamento e revisões do caso - muitas delas com a participação dos dois filhos do casal, Robert e Michael Meeropol -, predominam as interpretações que mostram o casal como vítima de um complô orquestrado para garantir a condenação e, assim, fixar um exemplo a fim de inibir futuros atos de rebeldia contra o governo americano, que, no contexto da Guerra Fria, reagia com especial rigor a ações que considerasse simpáticas à causa comunista. Howard Zinn relata as articulações nos bastidores do julgamento: "FBI documents subpoenaed in the 1970s showed that Judge Kaufman had conferred with the prosecutors secretly about the sentences he would give in the case. Another document shows that after three years of appeal a meeting took place between Attorney General Herbert Brownell and Chief Justice Fred Vinson of the Supreme Court, and the chief justice assured the Attorney General that if any Supreme Court justice gave a stay of execution, he would immediately call a full court session and override it". (ZINN, Howard. A People's History of the United States. New York: Harper \& Row, 1980, p. 426). Apesar das inúmeras revisões do caso e das novas evidências em favor da tese de que os Rosenberg não teriam tido uma participação tão relevante em atividades de espionagem favoráveis à URSS, uma aura de traidores da nação persiste na imagem do casal até hoje.
} 
Livro de Daniel: Uma Vida Entregue em Cumprimento Parcial das Exigências do Grau de Doutorado em Biologia Social, Entomologia Grosseira, Anatomia Feminina, Cacofonia Infantil, Arquidemonologia, Escatologia e Poluição Térmica ${ }^{62}$ (p. 317).

O enredo do romance é dividido em vários planos temporais que se distribuem de maneira não cronológica. Desses, os principais são os anos 50 - palco do julgamento e execução do casal Isaacson e de parte da infância de Daniel e Susan, sua irmã - e os anos 60 - no qual acompanhamos a tentativa de suicídio de Susan (e depois sua morte no hospital psiquiátrico após período de convalescência) e a investigação de Daniel sobre o passado de militância política da família. A narrativa é interrompida em 1968 quando um protesto de estudantes fecha a Universidade de Colúmbia e obriga Daniel a encerrar seu relato e sair do conforto da biblioteca para a insegurança da rua.

Por meio da vida de Daniel desenha-se um panorama da história do passado radical $^{63}$ americano no século XX - da Velha Esquerda dos anos 30, representada no romance pelos pais do narrador, à Nova Esquerda, que ganha força nos anos 60 e cuja

\footnotetext{
${ }^{62}$ No original: DANIEL'S BOOK: A Life Submitted in Partial Fulfillment of the Requirements for Doctoral Degree in Social Biology, Gross Entomology, Women's Anatomy, Children's Cacophony, Arch Demonology, Eschatology, and Thermal Pollution (p. 302). As páginas indicadas entre parênteses são das edições em português e inglês que constam da bibliografia.

${ }^{63}$ Será usada, nesta tese, a distinção entre "radical" e "revolucionário" estabelecida por Antônio Cândido e Raymond Williams: "Quando o Duque de La Rochefoucauld-Liancourt deu a notícia da tomada da Bastilha a Luís XVI, este perguntou atônito: "Mas então é uma revolta?". E o outro: "Não, Senhor, é uma revolução". Glosando os termos desse diálogo célebre, dir-se-ia que o radical é sobretudo um revoltado, e embora o seu pensamento possa avançar até posições realmente transformadoras, pode também recuar para posições conservadoras. Mesmo que o pensamento chegue a um teor de ousadia equivalente a do pensamento revolucionário, em geral ele não produz um comportamento revolucionário. O revolucionário, mesmo de origem burguesa, é capaz de sair da sua classe; mas o radical, quase nunca. Assim, o revolucionário e o radical podem ter idéias equivalentes, mas enquanto o primeiro chega até a ação adequada a elas, isto não acontece com o segundo, que em geral contemporiza na hora da ruptura definitiva". (CÂNDIDO, Antônio. Radicalismos. Estud. av., Abr 1990, vol.4, no.8, pp. 4-18) "Embora tenha havido imitações na Europa e em outras partes, é provável que se possa relacionar a escolha de radical, especialmente nos Estados Unidos, às dificuldades de meados do Século XX com a definição de Socialista e Comunista. Radical parecia oferecer um modo de evitar associações dogmáticas e faccionais, enquanto assegurava a necessidade de mudanças vigorosas e fundamentais. Ao mesmo tempo, evitava algumas das dificuldades em revolucionário, ao fazer a distinção necessária entre um levante armado e uma oposição militante ao sistema político". (WILLIAMS, Raymond. PalavrasChave - um vocabulário de cultura e sociedade. São Paulo: Boitempo, 2007, p. 340).
} 
presença no romance se anuncia na figura de Susan, integrante da $\operatorname{SDS}^{64}$. O caso Rosenberg é central na constituição desse panorama. É em seu significado nos anos 50 e 60, bem como no sentido do radicalismo político de esquerda e da reação a ele nos Estados Unidos, que a investigação de Daniel vai se concentrar. Doctorow, falando sobre os anos 60 - cenário da investigação de Daniel no romance - explica a centralidade do controverso julgamento dos Rosenberg para a história que queria contar:

Dos campi surgiu algo chamado de Nova Esquerda, e comecei a imaginar como ela se comparava à Velha Esquerda dos anos 30. Ocorreu-me que eu poderia contar a história da vida desse país ao longo de um período de 30 anos por meio de seus dissidentes, e percebi que os Rosenberg poderiam ser o fulcro. Tudo se encaixou $^{65}$.

Em entrevista, Doctorow comenta sua motivação para trabalhar literariamente o caso Rosenberg e explicita sua leitura simbólica, que será desenvolvida no romance, da execução de Julius e Ethel Rosenberg como um índice do que ele chama de "papel sacrifical ${ }^{66 "}$ da posição de esquerda nos Estados Unidos:

\footnotetext{
${ }^{64}$ Sigla em inglês para Students for a Democratic Society. Foi o maior e mais influente grupo de estudantes de esquerda atuando nos anos 60. Teve uma participação importante no fechamento da Universidade de Colúmbia em 1968. Cf. http://www.sds-1960s.org/
}

65 "Out of the campuses came something called the New left, and I began to wonder how it compared with the Old left of the 30s. It occured to me that I could tell the story of this country's life over a 30-year period by dealing with its dissidents. And I realised that the Rosenbergs could be the fulcrum. Everything snapped together." (In: CROWN, Sarah. E. L. Doctorow: "I don't have a style, but the books do". The Guardian, London, 23 de Janeiro de 2010, Culture, Books. Disponível em <http://www.guardian.co.uk/books/2010/jan/23/el-doctorow-homer-andlamgley>) Tradução minha.

${ }^{66}$ Um outro caso histórico de dissidentes políticos condenados e executados na cadeira elétrica em julgamento mais ideológico do que "factual" (em certa medida, todo julgamento é ideológico) foi o de Sacco e Vanzetti (mencionado por Daniel em pelo menos duas ocasiões). Este, como outros casos de perseguição política - dos quais a história da Esquerda americana está repleta - é comumente descrito em termos - muitas vezes religiosos - que remetem a ideias de sacrifício e martírio. Uma rápida olhada na vasta bibliografia sobre o caso Sacco e Vanzetti releva essa tendência de leitura: FAST, Howard. The Passion of Sacco and Vanzetti. New York: Blue Heron Press, 1953. / BUSH, Martin H. The Passion of Sacco and Vanzetti. Syracuse, N.Y: Syracuse University, 1968. / CLAFLIN, C. I. The Martyrs of Massachusetts. Birmingham, England: Birmingham Printers, 1927. / FEUERLICHT, Roberta Strauss. Justice Crucified: The Story of Sacco and Vanzetti. New York: McGraw-Hill, 1977. / MARCANTONIO, Vito. Labor's Martyrs: Haymarket 1887, Sacco and Vanzetti 1927. New York: Workers Library Publishers, 1937. I JOSEPHSON, Matthew. "The Passion of Sacco-Vanzetti." New Republic, April 20, 1932, p. 275. / KNOX, Robert. "Labor's Deathless Martyrs: A Statement by International Labor Defense on the Execution of Sacco and Vanzetti." Labor Defender, October 1927, pp. 147-48. / MCGIRR, Lisa. "The Passion of Sacco and Vanzetti: A Global History." Journal of American History, 93 
No final dos anos 60 eu me vi pensando sobre o caso Rosenberg e parece-me que, quanto mais eu me achava pensando nisso, mais eu via que isso era algo sobre o qual eu poderia escrever. E, não sabendo por que ou como ou a que conclusões eu estava chegando, comecei a escrever aquele livro e descobri que eu poderia por muita coisa lá - não somente a explícita e particular história de duas pessoas que foram encurraladas daquela maneira, mas também a história da Esquerda americana em geral, e do, em geral, papel sacrifical que ela tem assumido na nossa história ${ }^{67}$.

A ideia de sacrifício a que Doctorow relaciona, na passagem acima, a militância política da esquerda nos Estados Unidos aparece no romance de várias formas: no gesto heroico de Paul, que, durante ataque de fascistas contra os ônibus que voltavam de um show do comunista Paul Robeson, tem seu braço quebrado na tentativa de salvar o resto do grupo; na hipótese de Daniel de que seus pais, em ato sacrificial, se deixaram executar para encobrir as atividades de outro casal de espiões; na tese obliquamente desenvolvida por Daniel sobre o castigo corporal como distinção de classe, na qual ele relata exemplos de tortura e execução cruel contra dissidentes em várias épocas e lugares; na morte de Susan, que tenta o suicídio depois de falhar na busca de um significado político para a morte de seus pais e para o legado desse julgamento e dessa execução.

O livro recebeu muitas críticas, sobretudo de leitores conservadores, por supostamente ser uma defesa dos Rosenberg. Contra essa suspeita, Doctorow reage:

As pessoas que não o leram o supõem uma ingênua defesa dos Rosenberg. Ele não o é. O livro não tira conclusões sobre a culpa dos Rosenberg: ele não é sobre eles; é sobre o que aconteceu a eles. É sobre a condição da mentalidade deste país ${ }^{68}$.

(March 2007), 1085-115. / SACHS, H. "The Passion of Sacco and Vanzetti." Road to Freedom, May 1932, p. 5.

67 "In the late Sixties I found myself thinking about the Rosenberg case, and it seemed to me that the more I found myself thinking about it, I saw that it was something that I could write. And not knowing why or how or what conclusions I was going to come to, I started to write that book and discovered I could hang an awful lot on it - not only the explicit and particular story of two people who were trapped in this way, but also the story of the American left in general and the generally sacrificial role it has played in our history." (TRENNER, Richard. E.L. Doctorow - Essays and Conversations. Princeton: Ontario Review Press, 1983, p. 61.) Tradução minha.

68"People who haven't read it assume it's a simple-minded defence of the Rosenbergs. It's not. The book doesn't draw conclusions about their guilt: it wasn't about them, it was about what happened to them. It was about the state of this country's mind." (In: CROWN, op. cit.) Tradução minha. 
A "condição da mentalidade do país" ("state of this country's mind") da qual os Rosenberg foram vítimas é o estado de histeria e perseguição política estabelecido nos anos 50 e cuja expressão mais eloquente e perversa é o Macarthismo. Doctorow comenta o impacto da Guerra Fria na constituição psíquica do povo americano:

Se me fosse dado o Discurso Sobre o Estado de Mente da União ${ }^{69}$, eu nos descreveria hoje como convalescentes. "A realidade supera a compreensão" dizia Melville, falando da baleia branca, e assim, em espírito, em corpo, nós estamos ainda, até certo ponto, sofrendo nossa Guerra Fria. Isso pode estar relacionado aos anos de nossa negação. Houve momentos em que estávamos tão acostumados aos perigos de guerra que vivíamos e trabalhávamos como se ela não existisse. (...) Mais ainda, apesar de ser a União Soviética o inimigo a ser contido, o ânimo criativo da nossa mente belicista foi desencadeado, a um grau espantoso, contra nós mesmos $^{70}$.

Em um dos trechos ensaísticos do romance ${ }^{71}$ - supostamente parte da tese que Daniel nunca termina e que nunca se anuncia claramente no livro - o narrador analisa o prolongamento, para além da histeria bélica, do estado de guerra:

\section{Um Interessante Fenômeno}

Diversos historiadores observaram um interessante fenômeno da vida americana nos anos imediatamente posteriores a uma guerra. Nos círculos governamentais, um feroz partidarismo substitui as necessárias coalizões políticas dos tempos de guerra. Na grande arena das relações sociais - negócios, trabalho, comunidade - surge a violência, o medo, as recriminações dominam os debates públicos, a paixão prevalece sobre a razão. Muitos historiadores

\footnotetext{
${ }^{69}$ No original: "State of the Mind of the Union address" é um jogo de palavras com o "State of the Union", discurso feito pelo presidente americano anualmente sobre os temas que serão destaque na sua agenda.

${ }^{70}$ No original: If I were giving a State of the Mind of the Union address, I would describe us today as convalescing. "Reality outraces apprehension," Melville says, speaking of the white whale, and so in spirit, in body, we are still to some extent suffering our cold war. This may have to do with the years of our denial. There were times when we were so inured to war's dangers that we lived and worked as if it didn't exist. (...)What is more, though the enemy to be contained was the Soviet Union, the creative animus of our warring mind was unleashed, to an astonishing degree, upon ourselves. (DOCTOROW, E. L. Jack London, Hemingway, and the Constitution: selected essays, 1977-1992. New York: Random House, 1993) Tradução minha.

${ }^{71}$ Há, no romance, uma série desses pequenos exercícios críticos nos quais o narrador elabora alguns dos temas políticos que atuam como forças invisíveis nos destinos dos personagens.
} 
observaram o fenômeno, que é atribuído ao prolongamento da histeria bélica para além da guerra. Infelizmente, a febre emocional necessária ao combate não pode ser desligada como uma torneira. É preciso descobrir inimigos. A mente e o coração ${ }^{72}$ não podem ser desmobilizados tão rápido como um pelotão. Pelo contrário, como uma fornalha incandescente, leva muito tempo para esfriar ${ }^{73}$. (p. 32)

O "fenômeno" observado pelos historiadores citados por Daniel é historicamente confirmado pelas ações do governo Truman logo após a Segunda Guerra Mundial, que ajudaram a criar uma atmosfera de crise e de temor propícia ao surgimento do conflito conhecido como Guerra Fria ${ }^{74}$.

Daniel retoma sua pesquisa sobre o contexto no qual o julgamento de seus pais se deu em uma seção do livro intitulada “The True History of the Cold War”. Nela, aparecem

\footnotetext{
72 "The mind and the heart" - menção a uma estratégia de conquista há muito presente na relação dos Estados Unidos com o mundo, mas que ganhou maior visibilidade a partir do discurso de Lyndon Johnson feito em maio de 1965 em que ele diz: "We must be ready to fight in Vietnam, but the ultimate victory will depend upon the hearts and the minds of the people who actually live out there." Em 1974, Peter Davis lança o documentário "Hearts and Minds", que mostraria ao povo americano uma versão mais verdadeira do significado da famosa expressão da política externa americana. Evidentemente, Daniel não poderia ter visto o filme de Davis, mas certamente reconheceria nele verdades já intuídas em seu livro.
}

${ }^{73}$ No original: Many historians have noted an interesting phenomenon in American life in the years immediately after a war. In the councils of government fierce partisanship replaces the necessary political coalitions of wartime. In the greater arena of social relations - business, labor, the community - violence rises, fear and recrimination dominate public discussion, passion prevails over reason. Many historians have noted this phenomenon. It is attributed to the continuance beyond the end of the war of the war hysteria. Unfortunately, the necessary emotional fever for fighting a war cannot be turned off like a water faucet. Enemies must continue to be found. The mind and the heart cannot be demobilized as quickly as the platoon. On the contrary, like a fiery furnace at white heat, it takes a considerable time to cool. (p. 23).

${ }^{74}$ Como nos informa Howard Zinn: "It was an old lesson learned by governments: that war solves problems of control. Charles E. Wilson, the president of General Electric Corporation, was so happy about the wartime situation that he suggested a continuing alliance between business and the military for 'a permanent war economy.' / That is what happened. When, right after the war, the American public, war-weary, seemed to favor demobilization and disarmament, the Truman administration (Roosevelt had died in April 1945) worked to create an atmosphere of crisis and cold war. (...) / In a series of moves abroad and at home, it established a climate of fear - a hysteria about Communism - which would steeply escalate the military budget and stimulate the economy with war-related orders. This combination of policies would permit more aggressive actions abroad, more repressive actions at home. / Revolutionary movements in Europe and Asia were described to the American public as examples of Soviet expansionism - thus recalling the indignation against Hitler's aggressions". (ZINN, Howard. A People's History of the United States. New York: Harper \& Row, 1980, p. 416-417). 
trechos ensaísticos - separados entre si por espaçamento e marcadores - que trazem breves dissertações sobre assuntos como: a origem do termo "Guerra Fria"; definição de "Guerra Fria"; o uso diplomático do temporário monopólio atômico americano; A “política das portas abertas" implementada pelo governo Truman; a política pós-guerra da Rússia; a intensa propaganda antissoviética elaborada e implementada pelo governo dos Estados Unidos a partir de 1947; o Plano Marshall e a "doutrina Truman”.

Os dados que o Daniel pesquisador nos apresenta vão construindo uma visão à contrapelo da história da Guerra Fria, como pode ser observado no trecho a seguir, no qual ele sugere que o conflito não-declarado entre Estados Unidos e U.R.S.S era conveniente à política interna do governo americano, uma vez que criava uma justificativa para ações de repressão aos cidadãos que fossem considerados perigosos aos interesses da "segurança nacional":

Um Comitê Parlamentar registra, em 1947, um volume sem precedentes de propaganda antissoviética originária do governo americano. Acontece que é absolutamente necessária. De um lado, a América do Norte se considera o país mais poderoso, a primeira e única nação nuclear e a mais forte e mais poderosa do mundo. Por outro lado, tem que conviver com o temor dos russos. O Secretário de Estado Acheson haveria de declarar, anos mais tarde, que nunca, nas reuniões de gabinete de Truman, alguém considerou a Rússia como uma séria ameaça militar, mesmo depois que conseguiram a bomba. $\mathrm{O}$ senador-estadista Vandenberg, bipartidário, narra como se consegue o truque: "precisamos assustar o povo americano"75. (pp. 249-250)

A partir do caso Rosenberg, o romance articula diferentes visões da Esquerda americana ao longo do século XX. Um personagem nomeado pelo Daniel criança "o homem metido" ("the show off man") discute "os aspectos domésticos da Guerra Fria" (p. 98) com Paul Isaacson e apresenta uma visão da Velha Esquerda sobre o assunto, bem

\footnotetext{
75 No original: A Congressional Committee in 1947 reports on the unprecedented volume of antiSoviet propaganda coming out of the U.S. Government. It turns out to be absolutely necessary. On the one hand America considers itself the strongest nation, the first and only nuclear nation, the wealthiest, the most powerful nation in the world. On the other hand it must live in fear of the Russian. Secretary of State Acheson will testify some years afterward that never in the counsels of the Truman cabinet did anyone seriously regard Russia as a military threat-even after they got the bomb. Bipartisan Senator-Statesman Vandenberg tells how the trick is done: We've got to scare the hell out of the American people, he says. (pp. 237-238).
} 
mais otimista que a visão de Daniel, que - lembremos - escreve seu livro nos anos 60. Diz o "homem metido":

...toda a pressão contra-revolucionária exercer[á] efeito contrário àquele que desejam. Servir[á] apenas para unir, fortalecer e ampliar o movimento progressista deste país. Abrir[á] os olhos e desenvolver[á] politicamente todos aqueles que, talvez de outro modo, acreditassem que o capitalismo imperialista é sensato e que existem outras soluções menos radicais do que o marxismoleninismo para a transformação social da América $^{76}$. (p. 98)

Paul Isaacson, de maneira semelhante a Julius Rosenberg, acredita nas instituições e na democracia e repudia a "caça às bruxas" que se intensifica contra os radicais de esquerda no final da década de 40. O "homem metido", em diálogo com Paul sobre recentes prisões de militantes de esquerda pelo FBI, profeticamente aponta o perigo na posição do pai de Daniel:

- E acha inacreditável... Você é ainda um homem jovem, Isaacson. Não amadureceu plenamente. Tem bom coração, mas ele o trai. Se não consegue distinguir as forças reacionárias e sua inevitabilidade dialética, elas se tornam duplamente perigosas. É um erro terrível esperar qualquer esclarecimento ${ }^{77}$. (p. 98)

Cushing Strout ressalta a semelhança entre Paul Isaacson e Julius Rosenberg no que concerne à confiança que depositavam no sistema judiciário, na democracia e na "opinião pública"78. Essa confiança é afirmada no romance nas falas de Paul e nas cartas que ele escreve para sua esposa, as quais são reproduzidas por Daniel. Para parte da nova

\footnotetext{
${ }^{76}$ No original: the domestic aspects of the cold war, all the counterrevolutionary harassment, will have just the opposite effect of what they want. It will only unify and strengthen and broaden the progressive movement in this country. It will open the eyes and politically develop all those who may have otherwise believed that imperialist capitalism is reasonable, and that there are other less radical answers than Marxism-Leninism for the social transformation of America. (p. 86).

${ }^{77}$ No original: And you find it unbelievable... You are still a young man, Isaacson. You are not fully matured. You have a good heart, but it deceives you. If you cannot recognize the forces of reaction and their dialectical inevitability, they become twice as dangerous. It is a terrible mistake to expect any enlightenment from them. (p. 87).

78 "Doctorow's fictional hypothesis historically fits with some of the evidence. (...) It fits as well with the Death House Letters of Julius Rosenberg, which persistently and touchingly affirms his confidence that the Bill of Rights and an enlightened public opinion will finally acquit them". (STROUT, Cushing. Reconsidering the Rosenbergs: History, Novel, Film. Reviews in American History, Vol. 12, No. 3 (Sep., 1984), pp. 309-321. The Johns Hopkins University Press. http://www.jstor.org/stable/2702238. Acesso em: 16 de Junho de 2013, p. 314).
} 
geração de radicais dos anos 60, a ingenuidade dos Isaacson foi um erro de análise e sua morte não traz mais nenhuma lição para o presente. O personagem Artie Sternlicht - misto de radical e performer - julga ingênua a postura de integridade ideológica que o casal Isaacson adotou durante o processo que os levou à cadeira elétrica. Também julga ingênua a crença que os Isaacson depositavam no sistema judiciário, na democracia e na liberdade de expressão. Ele expõe a Daniel sua opinião sobre o assunto:

Seus pais não sabiam de porra nenhuma. A maneira como se portaram no julgamento foi patética. Agiram segundo as regras deles. As regras do governo. Sabe o que quero dizer? Em vez de se levantarem e dizerem: "vão para o diabo, façam o que quiserem, não posso ser julgado honestamente por vocês", redigiram moções, alegaram inocência, falaram somente quando falavam com eles, jogaram o jogo direitinho. Tudo certo? Todas as coordenadas aniquilaram-nos porque agiram como réus no julgamento, sacou $?^{79}$. (p. 164)

O empenho em dar sentido à morte de seus pais conduz Daniel a uma reflexão profunda sobre o passado radical americano e seu legado para a geração da qual ele faz parte. O caso Isaacson funda os alicerces sobre os quais Daniel tentará construir uma ponte entre duas gerações da Esquerda americana ${ }^{80}$. As dificuldades desse empreendimento estão impressas formalmente no romance e sugeridas no trecho a seguir, em que Daniel comenta uma pergunta de seu orientador de doutorado:

Faço a pergunta do professor Sukenick: em que circunstâncias renunciamos à crítica? Observe-se aqui um nítido exemplo do paradoxo da sensibilidade literária, formada pela geração anterior $^{81}$. (p. 204)

\footnotetext{
${ }^{79}$ No original: Your folks didn't know shit. The way they handled themselves at their trial was pathetic. I mean they played it by their rules. The government's rules. You know what I mean? Instead of standing an saying fuck you, do what you want, I can't get an honest trial anyway with you fuckers - they made motions, they pleaded innocent, they spoke only when spoken to, they played the game. All right? The whole frame of reference brought them down because they acted like defendants at a trial. You dig? (p. 151).

${ }^{80}$ De acordo com Paul Levine, “... the Isaacsons come to symbolize the legacy that one generation leaves another: the legacy of the Cold War, on the one hand, and of the Old Left, on the other" (LEVINE, Paul. In: DOCTOROW, E. L. Three screenplays.Baltimore: Johns Hopkins University Press, 2003, p. 16).

${ }^{81}$ No original: I ask the question of Professor Sukenick: Under what circumstances do we suspend criticism? Note the clear instance here of the paradox of the literary sensibility - that it is formed by the previous generation". (p. 192).
} 
Esse trecho aparece imediatamente após uma carta de Rochelle para Paul na qual ela reafirma sua convicção de que o julgamento garantirá que a verdade apareça e que eles sejam libertados. O "paradoxo da sensibilidade literária", que Daniel revela ao retomar as cartas de seus pais, marca a posição desse narrador que tenta compreender o destino dos seus pais e sua herança para o futuro político da Esquerda americana, mas está mergulhado num presente que rejeita as convicções e estratégias políticas das gerações anteriores. Assim, formada pela geração anterior, a "sensibilidade literária" se vê alheia ao presente e incapaz de tecer diagnósticos a partir de suas coordenadas conceituais, que, supostamente, não se mostram mais úteis no presente.

A dificuldade da Esquerda americana em encontrar continuidades entre as sucessivas gerações de militantes - grande tema do romance e formalmente codificada na figura do narrador ambivalente - é exposta nesse pequeno trecho sobre a "sensibilidade literária" de cada geração. Não é coincidência que a questão da falta de continuidade entre as gerações também apareça nas histórias da Esquerda americana, que costumam ser organizadas por gerações ${ }^{82}$.

Como matéria literária, o caso Rosenberg, dada a sua abertura ${ }^{83}$, possibilita uma infinidade de abordagens e cruzamentos. Estudando a apropriação que Doctorow fez do

\footnotetext{
${ }^{82}$ Como exemplo, vejamos como dois autores dividem a história da Esquerda nos Estados Unidos em três momentos. Para James Weinstein, "the American left since 1900 has started anew and failed three times. (...) ... - the old Socialist Party of 1900 to 1919, the Communist Party, which arose after the formation of the Third International in 1919 and finally collapsed in 1956, and the 'new left' of the 1960s" (WEINSTEIN, James. Ambiguous Legacy - The Left in American Politics. New York: New Viewpoints, 1975, p. vii). John Patrick Diggins estuda a Esquerda americana como uma "experiência de geração" e afirma que "There is little historical continuity and even less political sympathy among different generations of the American Left" (DIGGINS, John Patrick. The Rise and Fall of the American Left. New York, London: W.W. Norton \& Company, 1992, p. 41).

${ }^{83}$ Observada por um dos seus principais investigadores: "... the Rosenberg case was like that proverbial grain of sand in which one can see a world." (SCHNEIR, Walter. Final Verdict What really happened in the Rosenberg Case. New York: Melville House Publishing, 2010, p. 18).
} 
caso, um crítico observou que o julgamento dos Rosenberg permanece aberto, do ponto de vista histórico, literário e psicológico ${ }^{84}$.

Como outros julgamentos polêmicos e inconclusos da história dos Estados Unidos - muitos dos quais também transformados em matéria literária, como o caso Sacco e Vanzetti, que é central para dois importantes romances norte-americanos: Boston, de Upton Sinclair, e a trilogia U.S.A, de John Dos Passos - o caso Rosenberg sintetiza de forma instrutiva uma série de tensões latentes na sociedade americana da sua época ${ }^{85}$.

No seu célebre e polêmico ensaio "False Documents", de 1977, Doctorow compara a "ambiguidade perplexa" dos grandes casos da justiça americana cujo resultado permanece aberto ao "verdadeiro romance", também ele mais interrogação do que resposta:

Considere aquelas ocasiões - julgamentos criminais em tribunais quando a sociedade mobiliza todo seu aparato investigativo para apreender a realidade factual. Fazendo uso das comprovadas regras da evidência e da sabedoria acumulada do nosso sistema de leis, nós determinamos a culpa ou a inocência dos réus que vão a julgamento. Ainda assim, os mais importantes julgamentos da nossa história - aqueles que reverberam nas nossas vidas e possuem mais significado para o nosso futuro - são aqueles nos quais o veredito é colocado em questão: Scopes, Sacco e Vanzetti, os Rosenberg. Fatos são enterrados, exumados, destituídos, contestados, abjurados. Há uma decisão do júri e, quando o contexto histórico e desfavorável do julgamento é examinado, uma subsequente decisão da história, e o julgamento brilha para sempre com exatamente aquela ambiguidade perplexa de um verdadeiro romance... ${ }^{86}$

84 “...em termos históricos e literários, o enredo [do caso Rosenberg] ainda não tem conclusão; em termos psicológicos, a nação ainda não alcançou fechamento". (DETWEILER, Robert. Carnival of Shame: Doctorow and the Rosenbergs. Religion and American Culture. A Journal of Interpretation, Vol. 6, No. 1, (Winter, 1996), pp. 63-85. University of California Press, p. 65 <http://www.jstor.org/stable/1123973> Acesso em: 19 de Junho de 2012).

${ }^{85}$ Walter Schneir ressalta a importância dos grandes julgamentos para a compreensão do momento histórico em que ocorrem: “... great cases - like those of Dreyfus, Sacco-Vanzetti, Mooney-Billings, the Scottsboro Boys, and the Rosenbergs - embody and illuminate major events and issues of their times." (SCHNEIR, op. cit., p. 18).

${ }^{86}$ No original: Consider those occasions - criminal trials in courts of law - when society arranges with all its investigative apparatus to apprehend factual reality. Using the tested rules of evidence and accrued wisdom of our system of laws we determine the guilt or innocence of defendants and come to judgment. Yet the most important trials in our history, those which reverberate in our lives and have most meaning for our future are those in which the judgment is called into question: Scopes, Sacco and Vanzetti, the Rosenbergs. Facts are buried, exhumed, deposed, contradicted, recanted. There is a decision by the jury and, when the historical and prejudicial context of the 


\section{A "ambiguidade perplexa" do romance: o caso Rosenberg em The Public Burning e The Book of Daniel.}

O caráter de "ambiguidade perplexa" que marca um julgamento como o dos Rosenberg e que Doctorow destaca como afim à própria forma do romance também é central em outra obra que tem a Guerra Fria como cenário: The Public Burning, de Robert Coover.

Publicado em 1977 - portanto, temporalmente próximo da publicação de The book of Daniel - o romance de Coover acompanha os últimos dias de Julius e Ethel Rosenberg antes da execução, ato final dessa "pequena peça de moralidade [morality play] para nossa geração ${ }^{87 \%}$.

Em tom irônico, essa história é contada por personagens como o "Tio Sam" espécie de personificação da consciência conservadora americana -, "The Phantom" personificação da ameaça comunista - e Richard Nixon, principal voz narrativa. Também figuram no romance trechos jornalísticos sobre a época da execução dos Rosenberg, distribuídos na página como se fossem versos e atribuídos ao "The Poet Laureate", espécie de personificação da Revista Time e, por extensão, de certa parte da sociedade americana a cujos interesses e opiniões essa publicação dá voz.

Como The Book of Daniel, o livro de Coover traz momentos metaficionais, nos quais o romance tematiza a sua própria tentativa de representar o mundo como um todo coerente. Por esse aspecto em comum, as duas obras são frequentemente comparadas e lidas como exemplos de narrativas de inspiração histórica que questionam seu próprio alcance cognitivo. Esse questionamento sobre a construção da representação histórica no romance se manifesta, por exemplo, na forma de uma espécie de instabilidade de sentido que permeia toda a narrativa em The Public Burning. Em declaração semelhante em tom

decision is examined, a subsequent judgment by history. And the trial shimmers forever with just that perplexing ambiguity of a true novel... (DOCTOROW, E. L. False Documents. In: TRENNER, Richard. E.L.Doctorow - Essays and Conversations. Princeton, New Jersey: Ontario Review Press, 1983, p. 23).

${ }^{87}$ Título do capítulo 7 da primeira parte do romance de Coover. 
e sentido a muitas dadas por Doctorow ${ }^{88}$, Coover fala da sensação de incerteza com que ele convive e a partir do qual escreve:

Our ways of looking at the world and of adjusting to it through fictions are changing. . . our old faith - one might better say our old sense of constructs derived from myths, legends, philosophy, fairy stories, histories and other fictions which help to explain what happens to us from day to day, why our governments are the way they are, why our institutions have the character they have, why the world turns as it does - has lost its efficacy. Not necessarily is it false; it is just not as efficacious as it was ${ }^{89}$.

O desconforto do autor com "as maneiras de olhar o mundo" por meio da ficção encontram reverberação no seu romance na forma de uma instabilidade de significados, na qual cada palavra vive no fio da navalha do sentido. No nível da linguagem, o livro é repleto de trocadilhos, jogos de palavras e pares mínimos fonéticos que revertem ou subvertem o sentido das palavras e criam um campo minado semântico no qual nenhum significado está a salvo. Vejamos alguns exemplos desse aspecto da linguagem em The Public Burning:

AMERICA THE ROPE OF THE WORLD
AMERICA THE RAPE OF THE WORLD

*

AMERICA THE RAKE OF THE WORLD

AMERICA THE FAKE OF THE WORLD

(p. 34)

$*$

AMERICA THE FATE OF THE WORLD

AMERICA THE HATE OF THE WORLD

(p. 34)

$*$

AMERICA THE POKE OF THE WORLD

AMERICA THE POPE OF THE WORLD

${ }^{88}$ Cf. TRENNER, Richard. E.L. Doctorow- Essays and Conversations. Princeton: Ontario Review Press, 1983, passim.

${ }^{89}$ COOVER, ROBERT apud SAVVAS, Theophilus. American Postmodernist Fiction and the Past. London: Palgrave Macmillan, 2011, p. 16. 
AMERICA THE HOPE OF THE WORLD

\begin{abstract}
(p. 65)
$*$

"If you lift the stay", snaps Finerty, his Irish cheeks aflush, "then God save the United

States and this honorable Court!" there are gasps in the courtroom at this old reprobate's vain use of the Lord's name, and many are sure they heard him say "dishonorable Court." (p. 73) ${ }^{90}$
\end{abstract}

\begin{abstract}
$* * *$
A instabilidade de sentido no romance também se mostra no duvidar sobre as possibilidades da representação de fatos históricos. O caso Rosenberg e toda a aura de segredo e conspiração que o envolve fornece matéria para as incursões metaficcionais do romance. Richard Nixon, a principal voz da narrativa, nos fala de sua repulsa ao paradoxo e da areia movediça epistemológica em que ele se afunda ao tentar entender, a partir de seu esquema simplista de pensamento, o caso Rosenberg e tudo o que o rodeia:

What was fact, what was intent, what was framework, what was essence? Strange, the impact of History, the grip it had on us, yet it was nothing but words. Accidental accretions for the most part, leaving most of the story out. We have not yet begun to explore the true power of the World, I thought. What if we broke all the rules, played games with the evidence, manipulated language itself, made History a partisan ally? Of course, the Phantom was already onto this, wasn't he? Ahead of us again. What were his dialectical machinations if not the dissolution of the natural limits of language, the conscious invention of a space, a spooky artificial no-man's land, between logical alternatives? I loved to debate both sides of any issue, but thinking about that strange space in between made me sweat. Paradox was one thing I hated more than psychiatrists and lady journalists ${ }^{91}$.
\end{abstract}

"Fazer da História um aliado político" por meio da quebra de todas as regras, do jogo com as evidências e da manipulação da própria linguagem é um dos principais objetivos dos dois lados envolvidos na guerra entre posições ideológicos em meio ao qual o julgamento dos Rosenbergs se deu. A “explícita e particular história de duas pessoas

\footnotetext{
${ }^{90}$ COOVER, Robert. The Public Burning. New York: Grove Press, 1997.

${ }^{91}$ Idem. p. 136.
} 
que foram encurraladas daquela maneira ${ }^{92} "$, que Doctorow também conta em seu livro, serve de ponto de partida a partir do qual os dois autores tecem uma teia de relações que liga alguns dos muitos fios soltos da história do período representado em ambos os livros, bem como de outra história mais ampla. A "invenção consciente de um espaço, uma artificial fantasmagórica terra de ninguém" que Nixon acredita ser obra das "maquinações dialéticas" dos russos (o "Fastasma") é na verdade o contexto de indefinições no qual se movem os personagens em ambos os romances aqui comparados, espaço no qual as “alternativas lógicas" tão confortáveis a Nixon estão entrando em colapso. O espaço "entre alternativas lógicas" inventado pelo "fantasma" e que causa tanto desconforto a Nixon é também um codinome para a dialética, essa inimiga da lógica ${ }^{93}$.

The Book of Daniel e The Public Burning compartilham a ideia de que o julgamento dos Rosenberg é um episódio central da história política americana nos anos de Guerra Fria e um no qual as tão celebradas liberdades individuais nos Estados Unidos são confrontadas pelas chamadas "razões de Estado". A carga de responsabilidade pelo futuro dos americanos colocada sobre os ombros dos radicais de esquerda Julius e Ethel Rosenberg pode ser percebida no texto da sentença que os condenou à morte, proferida pelo juiz Irving Kaufman:

I believe your conduct in putting into the hands of the Russians the A-bomb years before our best scientists predicted Russia would perfect the bomb has already caused the Communist aggression in Korea with the resultant casualties exceeding 50,000 Americans and who knows but that millions more of innocent people may pay the price of your treason ${ }^{94} \ldots$

\footnotetext{
${ }^{92}$ Ver citação no começo do capítulo.

93،"Todo mundo deveria saber que a lógica, por ser a expressão e o método da ideologia dominante (a guardiã da ordem), é a mais ferrenha inimiga da dialética. E não apenas porque não a entende nem tem condições de a entender, mas sobretudo porque seus cultores perceberam, desde a primeira metade do século XIX, que o pensamento dialético é uma ferramenta mortal nas mãos de seu inimigo de classe, o inimigo (e vítima) da ordem. Mas há razões internas, de método, para que os lógicos desfigurem e caricaturem a dialética, que vão além da estratégia de desmoralizar a contradição. Eles sabem que a contradição, como conceito e, como demonstrou Hegel, como motor do movimento do pensamento, pode ser considerada a própria essência da dialética". (CAMARGO, Iná Costa. Prefácio de Companhia do Latão - 7 peças. In: CARVALHO, Sérgio de, MARCIANO, Márcio. Companhia do Latão - 7 peças. São Paulo: Cosac Naify, 2008, p. 18).
}

${ }^{94}$ In: ZINN, op. cit., p. 425. 
O texto da sentença proferida pelo juiz Kaufman indica a tentativa de reduzir um jogo de forças complexo a um simples ato de traição de um casal de militantes, que teria agido contra seu próprio país sob a influência de uma ideologia nefasta. A moralização da política é a venda que nos cega a consciência para a apreensão do papel de agentes impessoais nos movimentos da história. De certa forma, os dois autores aqui comparados intuem o perigo de se tentar atribuir a indivíduos a responsabilidade por fatos derivados da ação de estruturas e forças mais complexas. No livro de Coover, o que se tem é uma visão em caleidoscópio dos bastidores do caso Rosenberg, que vai das dúvidas e receios de Nixon ao explícito posicionamento do Tio Sam. No livro de Doctorow, o projeto de Daniel de entender a real participação de seus pais no suposto roubo do segredo atômico é periférico na narrativa, só é anunciado com clareza nas últimas páginas do romance e não se fecha no final. Em ambos, há um esforço de rastrear o jogo de forças que atua no nível político-jurídico - com a condenação do casal - e no nível ideológico - com a espetacularização do julgamento e a afirmação de valores como o patriotismo e as supostas liberdades individuais garantidas a todos em países não-comunistas.

$$
* * *
$$

Em The Public Burning o modo narrativo irônico desestabiliza e põe em suspensão qualquer discurso que pretenda capturar uma versão definitiva do caso Rosenberg. Várias passagens do livro parodiam o discurso jornalístico, criando notícias sobre o julgamento as quais, mesmo escritas num tom de seriedade que tenta imitar a linguagem jornalística, logo são postas em suspenso pela torrente de chistes, paródias e falas cômicas que povoam a narrativa.

Contribui para esse efeito de desestabilização e suspensão do discurso a teatralização da morte dos Rosenberg no romance ${ }^{95}$. Significativamente, o local escolhido para a execução do casal de supostos espiões atômicos é a famosa Times Square, um dos ícones da "sociedade do espetáculo". O evento midiático real que foi a execução do casal Rosenberg em 1953 ganha, no romance, um claro caráter de espetáculo. Tendo a Times

\footnotetext{
${ }^{95}$ A última das seções do romance chamadas Intermezzos é uma ópera em um ato que traz Julius e Ethel como protagonistas e a prisão de Sing Sing como cenário. O título da obra é: Human Dignity Is Not for Sale: A Last-Act Sing Sing Opera by Julius e Ethel Rosenberg.
} 
Square como palco, o ato final desse drama encena de modo cômico o jogo de forças em luta nos anos 50 que se evidenciou nesse julgamento. Refletindo sobre essa "pequena peça de moralidade [morality play] para nossa geração ${ }^{96 "}$ que o drama do julgamento e execução de Julius e Ethel representou, o personagem Richard Nixon fala sobre a aparência de ato teatral que envolve o julgamento do casal:

Who could tell what was on Uncle Sam's mind? Certainly it was very theatrical. There was the drama of a brother sending his big sister to the electric chair; the implied tragedy of the Rosenberg children who would be left orphans; the curious spectacle of Jews prosecuting and judging Jews, then accusing each other of tribal disloyalties; an almost Wagnerian scope to the prosecution's presentation, incorporating many of the major issues of our times, whether or not relevant to the crime charged; the sense throughout that this was clearly a struggle between the forces of good and evil $\ldots$ and a lot of pretty fair spy stories to the bargain, if the prosecution was to be believed: secret codenames, recognition signals, covert drop sites, escape plans, cover stories, payoffs, catand-mouse games with FBI surveillance teams, border intrigues. But there was more to it than that. Not only was everybody in this case from judge on down - indeed, just about everyone in the nation, in and out of government, myself included - behaving like actors caught up in a play, but we all seamed moreover to be aware of just what we were doing and at the same time our inability, committed as we were to some higher purpose, some larger script as it were, to do otherwise. Even the Rosenbergs seemed to be swept up in this sense of an embracing and compelling drama, speaking in their letters of sinister "plots" and worldwide "themes" and "setting the stage" and playing the parts they had been - rightly or wrongly - cast for "with honor and with dignity 97 ".

A representação do julgamento e execução dos Rosenberg como uma peça de moralidade sublinha o caráter maniqueísta do ambiente ideológico no qual o caso se desenvolveu. Nixon expressa no trecho acima a percepção de que esse caso suscitou uma "clara luta entre as forças do bem e do mal" e que tal encenação do conflito entre essas forças é obra do engenho do Tio Sam. Em diálogo com Nixon, Tio Sam ressalta o caráter pedagógico que a execução dos Rosenberg deve ter para aqueles que cogitem se levantar contra a ordem hegemônica que o capitalismo americano pretende impor ao mundo:

\footnotetext{
${ }^{96}$ COOVER, op. cit., p. 111.

${ }^{97}$ Idem. p. 117.
} 
We ain't goin' up to Times Squares just to fulfill the statutorial law, if that's what you mean," Uncle Sam said. He blew a smoke ring, then another and another, each inside the other, ending with a little puff of smoke for the center. "This is to be a consecration, a new charter of the moral and social order of the Western World, the precedint on which the future is to be carn-structured to ensure peace in our time! ${ }^{98}$

Assim, vemos no romance como a visão simplista de mundo de personagens como Nixon e Tio Sam é parodiada e lançada num caldo de ambiguidades e perplexidades que evidencia a sua insuficiência. A leitura do caso Rosenberg feito por Tio Sam - segundo a qual a execução do casal estabelecerá um precedente a partir de que o futuro será "carnstructed $^{99 "} "$ - pressupõe uma divisão clara do mundo entre a ordem capitalista e seus opositores, os quais devem conviver com o risco de que se estabeleça a derradeira conexão: "a conexão entre a sociedade e sua morte ${ }^{100 "}$.

Claramente ridicularizado no romance - por seus gestos excêntricos, seus diálogos extravagantes e sua linguagem repleta de erros gramaticais - Tio Sam professa uma visão da história semelhante a de Henry Ford, personagem histórico com o qual o personagem ficcional divide pontos de vista e opiniões. Durante partida de golfe com Nixon, Sam faz uma leitura pragmática da manipulação dos fatos na construção da história oficial e, citando Ford, diz:

"Rig a prosecution?" Uncle Sam laughed sourly. I knew better, of course, I was being a fool. "Hell, all courtroom testimony about the past is ipso facto and teetotaciously a baldface lie, ain't that so? Moonshine! Chicanery! The ole gum game! Like history itself - all more or less bunk, as Henry Ford liked to say, as saintly and wise a pup as this nation's seen since the Gold Rush - the fatal slantindicular futility of Facts! Appearances, my boy, appearances! Practical politics consists in ignorin' facts! Opinion ultimately governs the world! ${ }^{101}$,

\footnotetext{
${ }^{98}$ Idem. p. 91.

${ }^{99}$ Jogo de palavras com carnal e estruturado, que dá um novo verbo cujo significado seria algo como "estruturado na carne" ou "carnestruturado".

${ }^{100}$ O Livro de Daniel, p. 154.

${ }^{101}$ COOVER, op. cit., p. 86.
} 
A célebre frase de Ford sobre a história, aqui citada por Tio Sam na sua versão mais conhecida, apareceu em uma entrevista para o Chicago Tribune, em 25 de maio de 1916. No seu contexto original, temos: "History is more or less bunk. It's tradition. We don't want tradition. We want to live in the present, and the only history that is worth a tinker's damn is the history that we make today." A semelhança entre Ford e Sam não para na reflexão historiográfica. A linguagem de Sam lembra a de Ford, como podemos observar na comparação entre as duas citações acima. Lembremos que Ford e sua visão de mundo são matéria de escárnio também em Ragtime, onde o grande industrial americano aparece em curioso e significativo diálogo com o banqueiro John Pierpont Morgan, como veremos no próximo capítulo.

The Book of Daniel e The Public Burning têm sido apontados como exemplos de um tipo de romance histórico que se volta para a história ao mesmo tempo em que questiona a própria possibilidade de existência de uma verdade sobre o passado. O que me interessa no estudo dessas duas obras é a tensão da forma que trabalha um conteúdo histórico - o caso Rosenberg - imbricado em uma teia de relações que escapa ao poder de decifração de uma consciência individual - o narrador, no romance - e implica numa crise de representação da qual a complexidade da forma nesses romances é sintoma.

O caso Rosenberg - matéria histórica dos dois romances - parece servir, nessas obras, como o fio solto de um emaranhado de relações que será seguido até onde a forma puder alcançar. Onde o fio se perde, a forma se desintegra em jogos de som, de sentido, em fragmentos desconexos, em episódios cômicos ou até bizarros, em rodeios do narrador em torno de ideias pouco claras (como veremos em alguns trechos de The Book of Daniel) e em reflexões meta-historiográficas. Todos esses elementos formais constituem, sobretudo, sintomas da dificuldade de representação da história como processo. $\mathrm{Na}$ ausência de claras linhas de coerência para costurar a narrativa da História, o desconexo e, por vezes, o nonsense delimitam na forma os limites da compreensão. 


\section{O ethos ambivalente do narrador em The Book of Daniel}

Daniel Isaacson Lewin, testemunha e vítima, como foi mostrado, de alguns dos momentos mais representativos da história da esquerda americana no século $\mathrm{XX}$, incorpora nos sobrenomes que carrega o conflito de identidade política que vai ser dramatizado em seu livro. Esse conflito é explicitado quando Daniel vai a Washington participar de uma mobilização em massa contra a Guerra do Vietnam ${ }^{102}$ e toma parte em uma manifestação de protesto dos estudantes na qual eles depositam seus certificados militares em uma mala postal a ser enviada ao Departamento de Justiça como forma de expressar reprovação à intervenção americana no Vietnam. O episódio é assim narrado por Daniel:

O objetivo do drama é alcançado e os cartões de convocação de centenas de universitários de todo o país são atirados numa sacola pelos seus representantes. Aplausos. Outros entre a multidão são convidados a acrescentar os seus. Muitos o fazem. Abro caminho entre a turba, deixo cair o meu cartão na bolsa e pronuncio meu nome ao microfone. Daniel Isaacson, embora o cartão estivesse em nome de Daniel Lewin. Sinto as orelhas arderem com uma onda de sentimento de justiça e temor. Que máscara. Mas vim até ali para fazer o que os outros fizessem ${ }^{103}$. (p. 265)

Com o gesto de escolher o nome de seus pais biológicos como apresentação para ingressar num ato de rebeldia contra o governo de seu país, Daniel evoca o passado radical da família na tentativa simbólica de formar um elo entre o radicalismo de sua geração (anos 60) e o do tempo de seus pais (anos 30). O simbolismo do gesto é logo questionado pelo cinismo do narrador, que sugere o engodo contido no suposto ato de rebeldia do qual participa sem muita convicção: "Sinto as orelhas arderem com uma onda de sentimento

\footnotetext{
${ }^{102}$ A presença no romance desse episódio da história americana - que ficou conhecido como Marcha ao Pentágono - será analisada mais adiante nesse capítulo.

${ }^{103}$ No original: The point of drama is reached and the draft cards of hundreds of college boys across the country are dropped in a pouch by their representatives. There is applause. Others in the crowd are invited to add their own cards. Many do. I make my way through the crowd, and drop my card into the pouch, and say my name into the microphone. Daniel Isaacson, although the card is in the name of Daniel Lewin. My ears glow from an inner surge of righteousness and fear. What a put-on. But I have come here to do whatever is being done. (p. 252).
} 
de justiça e temor. Que máscara.”. A expressão “que máscara” da versão em português é traduzida de "What a put-on", expressão interjetiva usada no inglês americano em contextos informais para definir uma "tentativa de levar alguém a acreditar em algo que não é verdadeiro ${ }^{104}$.

Neste episódio vemos um desenho da ambivalência que vai caracterizar o engajamento do narrador em grande parte do livro. A ida de Daniel para Washington e sua disposição a ceder à "lógica do meu direito e necessidade de ir até ali para fazer o que todos estão fazendo" (p. 267) indicam ao menos um desejo do narrador de se aproximar das questões de seu tempo. A escolha do nome Isaacson (em detrimento do sobrenome Lewin, de seus pais adotivos, um casal de liberais) indica a ligação que Daniel estabelece entre o ato de subversão do qual vai participar e o passado de radicalismo de sua família. No entanto, a maneira como ele descreve sua participação no gesto dos estudantes de devolver seus cartões de convocação ${ }^{105}$ como um "put-on" acrescenta um elemento de ironia que nega o suposto radicalismo do seu ato.

O ingresso de Daniel num dos rituais de rebeldia mais característicos de sua geração lhe traz frustração e revela a indefinição de sua identidade política, que vai ser questionada várias vezes ao longo da narrativa. No trecho a seguir, Daniel faz uso de sua consciência crítica apurada para analisar a sensação de deslocamento que o impede de compartilhar do sentimento geral de esperança no poder de mudança da multidão reunida na histórica Marcha ao Pentágono de 1967:

Nos degraus do Lincoln Memorial, roucos oradores gritam nos microfones. Sinto a concussão na concordância da multidão. Sou acometido pela assustadora convicção do direito maior de cada um de estar ali. Sinto-me de fora. Parece-me que praticamente todos (...) tomaram posse do acontecimento de um modo que não entendo. Tenho a impressão de me ter esgueirado para dentro sem ter pago, ou simplesmente ignorar algo que todos sabem. Que será possível ainda consegui-lo, quem sabe? Ou que já basta ${ }^{106}$. (p. 266)

${ }^{104}$ Online Cambridge Advanced Learner's Dictionary \& Thesaurus - Cambridge University Press. http://dictionary.cambridge.org/dictionary/british/put-on?q=put-on (Acessado em 20/03/2013).

${ }^{105}$ Comum entre os jovens do movimento pacifista nos Estados Unidos, o ato de queimar ou devolver o cartão de convocação implica em risco para o seu detentor, uma vez que o nãoatendimento à convocação das forças armadas pode resultar em punições. Portanto, além de simbólico, esse ato tem um caráter de desobediência civil que denota coragem e engajamento. Daí decorre sua importância para a caracterização de Daniel na cena há pouco descrita.

${ }^{106}$ No original: At the steps of Lincoln Memorial hoarse speakers shout into their microphones. I feel the concussion of crowd assent. I come under the awful conviction of everyone's greater right 
O episódio acima descrito é paradigmático de um movimento na caracterização do narrador que perpassa todo o romance. A narração oscila o tempo todo entre a ironia do politicamente desencantado Daniel - predominante e constantemente manifesta no fino raciocínio crítico desse doutorando de Colúmbia - e o latente desejo de engajamento do filho de radicais dos anos 30, vítimas da repressão política dos anos 50 . No romance, a investigação de Daniel sobre o passado de sua família, que é suscitada pela tentativa de suicídio de sua irmã, fornece o "fío vermelho ${ }^{107 "}$ " que tenta unir três momentos históricos da Esquerda americana tocados na narrativa: os anos 60, de onde Daniel escreve; os anos 50, palco da execução de seus pais; e os anos 30, período da formação política do casal Isaacson.

Com ironia, Daniel trata o episódio da tentativa de suicídio de sua irmã como uma intrusão bem-vinda na sua rotina acadêmica perigosamente apolítica. Dada a dificuldade da tradução de conotar a ironia sutil do narrador, vejamos o trecho no texto original:

He was thankful to Susan for relieving the dangerous tedium of his graduate life. She would be all right. In the meantime there was drama, a sweet fatality, a recharging of the weak diffused impulses of giving a shit ${ }^{108}$. (p. 15)

No enredo, a personagem Susan estabelece um contraponto de militância e engajamento político ao cinismo e a indefinição de Daniel. Para ele, em Susan "resides the fateful family gift for having definite feelings" (p. 9). Dessa forma, possuindo o "dom" da família de ter "sentimentos definidos", Susan se aproxima mais do convicto engajamento de seus pais do que Daniel. Ao mesmo tempo, esse "dom" é caracterizado por Daniel como "fatal", fato que será confirmado na narrativa pelas mortes de Paul, Rochelle e Susan e retomado num dos três finais ("2. O funeral") oferecidos por Daniel

to be here. I feel out of it. It seems to me that practically everyone here (...) has taken possession of the event in a way that is beyond me. I feel as if I have sneaked in, haven't paid, or simply don't know something that everyone knows. That it is possible to still do this, perhaps. Or that it is enough. (p. 254).

107 Termo adaptado de LÖWY, Michael. Franz Kafka, sonhador insubmisso. Rio de Janeiro: Azougue, 2005, p. 11.

108 "Sentiu-se grato a Susan por livrá-lo do perigoso tédio de sua vida de estudante. Ela ficaria boa. Entretanto, acontece drama, uma doce fatalidade, um recarregar dos impulsos fracos e difusos que precedem a evacuação." (pp. 23-24). 
para encerrar o livro. A contradição se instaura no nível da sentença, na qual "dom" ("gift") - palavra que tem conotação positiva em inglês - é modificada pelo adjetivo "fatal" ("fateful”), cuja conotação é negativa. Tal contradição revela um dos dilemas colocados pela narrativa: ter "sentimentos definidos" (lê-se convicções e posições políticas claras em oposição à indefinição ou à apatia) é algo que Daniel parece desejar, mas ter dificuldade de alcançar. Nesse sentido, seria um "dom”, compartilhado por Susan, Paul e Rochelle e não alcançado por Daniel. No entanto, a história americana - que fala no romance por meio do destino desses três personagens - ensina a Daniel uma dura lição, resumida no diagnóstico do psiquiatra de Susan de que para ela "a dissensão era traumática" ou na ideia do narrador de escrever um artigo sobre a "dinâmica do pensamento radical" no qual trataria da cadeia de conexões feitas pelo radical até chegar à derradeira ligação - "a conexão entre a sociedade e sua morte ${ }^{109 "}$.

A ambivalência dos sentimentos políticos de Daniel funciona ${ }^{110}$, para o narrador - como veremos ao final do romance -, como prevenção contra o destino fatal da família Isaacson. Apesar de escapar vivo do que Doctorow define como o "papel sacrificial ${ }^{111 "}$ da Esquerda americana na história política do país, Daniel é tragicamente marcado pela morte de toda sua família e pelo não-fechamento de sua investigação - triplamente inconclusa: ao final do romance, Daniel não termina sua tese de doutorado, não conclui sua investigação sobre a participação de seus pais no esquema de espionagem na qual foram eles implicados (uma vez que a chave para fechar o caso, o Doutor Mindish, não está mentalmente disponível para solucionar as dúvidas do narrador) e não fecha o romance, já que, além dos três finais dados como alternativas para a escolha do leitor, a própria escrita do livro de Daniel é bruscamente interrompida pelo fechamento da Universidade de Colúmbia em 1968. Tudo isso considerado, Daniel, de certa forma, também cai vítima do "papel sacrificial" da Esquerda americana e sua pena é a incompletude de seu projeto e as incertezas que ele divide com o leitor. Essa é a origem

\footnotetext{
${ }^{109}$ The Book of Daniel.

${ }^{110}$ Um crítico descreveu essa ambivalência do narrador como "ideological wavering" (SAVVAS, Theophilus. American Postmodernist Fiction and the Past. London: Palgrave Macmillan, 2011, p. 135).
}

111 TRENNER, op. cit., p. 61. 
da "angústia pungente" que Fredric Jameson descreve como uma possível reação de pessoas alinhadas ao pensamento de esquerda à leitura dos romances de Doctorow:

E. L. Doctorow é o poeta épico do desaparecimento do passado radical americano, ninguém que tenha simpatia pela esquerda é capaz de ler esses grandes romances sem sentir uma angústia pungente, que é uma maneira autêntica de confrontar nossos próprios dilemas políticos no presente ${ }^{112}$.

No mapa genealógico da militância política da família Isaacson, Daniel situa Susan numa linha que vem da avó deles - imigrante que chega aos Estados Unidos no começo do século XX e assiste às duas irmãs ${ }^{113}$ e ao marido serem explorados e perecerem - e passa por Rochelle, a mãe - significativamente nascida no agitado ano de $1919^{114}$. Em parágrafo separado, por espaço, do anterior e do subsequente e localizado logo após uma imaginária carta da avó morta para Daniel, aparece a descrição de uma imagem que sintetiza a genealogia política da família Isaacson:

Um livro de medicina. Nas páginas brancas e brilhantes há fotos de três corpos femininos. A pequenina e encarquilhada vovó, com sua cabeleira grisalha toda desgrenhada. Rochelle, forte, busto farto,

112 JAMESON, Fredic. Pós-Modernismo - A lógica Cultural do Capitalismo Tardio. São Paulo: Ática, 1996, p. 51.

${ }^{113}$ As tias-avós de Daniel morreram no histórico incêndio da Triangle Shirtwaist Company, na qual 146 trabalhadores perderam a vida. O episódio ficou registrado na história dos trabalhadores americanos como símbolo de exploração e desrespeito à vida do trabalhador. Howard Zinn descreve esse fato histórico: On the afternoon of March 25, 1911, a fire at the Triangle Shirtwaist Company that began in a rag bin swept through the eighth, ninth, and tenth floors, too high for fire ladders to reach. The fire chief of New York had said that his ladders could reach only to the seventh floor. But half of New York's 500,000 workers spent all day, perhaps twelve hours, above the seventh floor. The laws said factory doors had to open outward. But at the Triangle Company the doors opened in. The law said the doors could not be locked during working hours, but at the Triangle Company doors were usually locked so the company could keep track of the employees. And so, trapped, the young women were burned to death at their work-tables, or jammed against the locked exit door, or leaped to their deaths down the elevator shafts. (ZINN, op. cit., p. 319).

${ }^{114}$ Ethel Rosenberg nasceu em 1915. O fato de Doctorow ter feito Rochelle Isaacson nascer em 1919 não é fortuito: nascendo nesse ano e morrendo na década de 50, a vida de Rochelle praticamente coincide com o período de predomínio do Partido Comunista na vida da Esquerda americana, como nos informa Weinstein: "the communist party arose after the formation of the Third International in 1919 and finally collapsed in 1956" (WEINSTEIN, James. Ambiguous Legacy-The Left in American Politics. New York: New Viewpoints, 1975, p. vii). 
baixa, boca séria. E Susan, com seus óculos de vovozinha, contornados de finos aros dourados. Estão em fila no encarte da página dupla, palmas das mãos ligeiramente voltadas para fora, pés idem, nada oculto. Poderiam estar de pé ou deitadas. Vovó parece a encarquilhada matriarca de uma tribo aborígine. Rochelle tem busto, mas Susan é a mais alta e mais feminina. Todas têm triângulos, mas volte o olhar para cima. Trata-se de um livro de estudo. O sentido da foto está na linha fina, diagramática, vermelha, que passa do peitode vovó, atravessa o de mamãe e penetra o da irmã. A linha vermelha indica o avanço da loucura herdada através do coração ${ }^{115}$. (pp. 82-83)

Com ironia, a imagem criada por Daniel é explicada como uma representação do "o avanço da loucura herdada através do coração". Essa imagem de família forjada por Daniel com a linha vermelha a conectar as três gerações dos Isaacson pela "loucura" reforça a ideia de que o narrador deste romance tenta costurar com um "fio vermelho" momentos históricos da esquerda americana ${ }^{116}$. O fato de que essa herança vermelha da família Isaacson seja retratada pelo narrador como uma patologia (a loucura) e figure imaginativamente num livro de medicina remete ao suicídio de Susan e à maneira desconfiada, para dizer o mínimo, com a qual Daniel aborda sua história familiar/política.

A carta - que precede o trecho comentado acima - imaginada por Daniel como tendo sido escrita por sua avó - há muito morta - para ele já adulto, confirma o destino político da família e, significativamente, atribui a Daniel a tarefa de dar sentido a esse destino, tarefa que orientará as investigações do narrador e ocupará toda a narrativa. Vejamos um trecho da carta:

115 No original: Medical textbook. A medical textbook. On the white and shining pages are photographs of three female bodies. Little, withered Grandma with her head wildly twisted grey hair. Rochelle, strong, breasty, stocky, prim mouthed. And Susan in her thin gold glasses. They stand in a row across the double-page spread, palms turned slightly out, feet turned slightly out, nothing hidden. They could be standing up or lying down. Grandma looks like the wrinkled matriarch of an aboriginal tribe. Rochelle's got the bosoms, but Susan is taller and more feminine. They all have triangles, but move your gaze upward. This is a medical textbook. The meaning of the picture is in the thin, diagrammatic arrow line, colored red, that runs from Grandma's breast through your mama's and into your sister's. The red line describes the progress of madness inherited through the heart.(p. 71).

116 A presença da avó - representante de um período em que predominou o antigo partido socialista (1900-1919 - ano do surgimento de Rochelle e do partido comunista americano) amplia a genealogia da esquerda americana traçada pela história da família Isaacson, embora essa presença seja periférica no romance e maior espaço seja dado às décadas de 30, 50 e 60. 
E a minha cumplicidade no fato de existirem, o fruto do meu ventre, que eu assim enganei, é para mim um ultraje. Sou incapaz de permanecer em sua presença por causa do meu amor por eles, amor que não compreendem, e meu temor de suas blasfêmias, de seu imiscuir nos mecanismos profundos e complicados do universo. (...) E eles herdaram de mim também, assim como você, o excesso de paixão, aquela cintilante plenitude de vida que sempre assinala a vítima. O que possuímos em cada um de nós, um excesso de vida, é o que o mundo mais detesta. Ofendemos. Cheiramos mal de tanta vida. Nosso coração ama o mundo, mas não de maneira suave. Somos brutais de tanta vida e nossa brutalidade se chama sofrimento. (...)... talvez seja porque reconheci em você a força e a inocência que nos salvam a todos da derrota. Que nos exoneram do fato de termos vivido e justificam o nosso sofrimento ${ }^{117}$. (pp. 81-82)

A carta inventada por Daniel reflete sua distância do destino fatal que marcou sua família. Apesar de ter herdado, como toda sua família, o "excesso de paixão, aquela cintilante plenitude de vida que sempre assinala a vítima", Daniel, ao final, sobrevive, graças à "força e inocência" que salvaria a todos da derrota, reflete o narrador usando a voz imaginada de sua avó. Os sentimentos confusos de Daniel em relação ao engajamento de sua família se mostram nesta carta - escrita por ele mesmo - na qual se estabelece, simultaneamente, a herança de conflito com o mundo ("O que possuímos em cada um de nós, um excesso de vida, é o que o mundo mais detesta. Ofendemos. Cheiramos mal de tanta vida. Nosso coração ama o mundo, mas não de maneira suave”) e vitimização (“...o excesso de paixão, aquela cintilante plenitude de vida que sempre assinala a vítima") que ele traria também consigo; e sua posição de exceção do destino familiar (ele sobrevive e é por isso que consegue escrever a carta imaginada e o livro), sua "força e inocência".

A narrativa em The Book of Daniel é o resultado da tentativa do narrador de se "imiscuir nos mecanismos profundos e complicados do universo", de criar conexões entre a história de sua família e a história americana, entre a luta política de seus pais e a luta

\footnotetext{
${ }^{117}$ No original: And my complicity in their being, the fruit of my womb, that I could have tricked them this way outrages me. Unable to stay in their presence for my love of them which they do not understand, and my terrible fear of their blasphemy, and their tampering with all the deep, intricate solderings of the universe. (...) And they inherit that from me, too, as you do, that excess of passion that shimmering fullness of stored life which always marks the victim. What we have, too much life in each of us, is what the world hates most. We offend. We stink with life. Our hearts make love to the world not gently. We are brutal with life and our brutality is called suffering. (...) ... perhaps it is that I recognized in you the strength and innocence that will reclaim us all from defeat. That will exonerate our having lived and justify our suffering. (p. 70).
} 
de sua irmã. A dificuldade de tal tarefa é formalmente traduzida no ethos ambivalente do narrador, o qual faz com que grande parte da narração seja passível de escrutínio para definir o grau de cinismo, ironia ou verossimilhança com que Daniel trata o seu relato ${ }^{118}$.

O ethos ambivalente do narrador, sua confusão a respeito dos dados que tem e a dificuldade de lhes conferir sentido e de tecer conexões, o leva frequentemente a um curto-circuito narrativo, do qual saltam faíscas de sentido cujo significado deve ser captado à luz do livro como um todo e da atenção para o fato de que Daniel está, na verdade, rabiscando ideias numa biblioteca enquanto o romance se escreve. Esse traço formal de The Book of Daniel, presente em várias passagens do romance, pode ser visto no parágrafo a seguir:

Baseado na teoria de que o que ocorre está certo, qualquer ato é correto por ter acontecido. E que tem a teoria? Só serve se funcionar. Preocupo-me com imagens. Imagens são o significado das coisas. Tomemos a palavra imagem. Sugere carne macia, nua, cintilando no ar como o arco-íris de uma bolha. Imagem sugere imagens, sendo a multiplicidade uma imagem. Imagens rompemse com um leve estalido. Sua destruição é tão maravilhosa quanto sua existência. São em essência instrumentos de tortura explodindo através da calejada capacidade do indivíduo para sentir fortes e difusas emoções plenas de anseio, insatisfação e amplitude. Não têm qualquer finalidade social ${ }^{119}$. (p. 83)

${ }^{118}$ É justamente esse ethos ambivalente do narrador Daniel que dá margem a leituras desse romance como exemplar do alto grau de reflexibilidade da narrativa contemporânea. Essa característica do romance contemporâneo, sobretudo da ficção histórica, é vista como um traço próximo em intenção ao caráter reflexivo, meta-historiográfico, do trabalho de alguns historiadores pós-modernos. Cf. HUTCHEON, Linda. A Poetics of Postmodernism: History, Theory, Fiction. London \& New York: Routledge, 1988. Esse tipo de leitura não interessa ao presente estudo por frequentemente desembocar no relativismo e na equivalência de múltiplas narrativas, enquanto aqui trabalhamos com o pressuposto de que "o programa ao qual as várias ideologias contemporâneas do pluralismo se ligam de maneira passional seja extremamente negativo: a saber, impedir aquela articulação sistêmica e totalizadora dos resultados interpretativos, que só pode levar a embaraçosas perguntas quanto à relação entre eles e, em particular, ao lugar da História e ao fundamento último da narrativa e da produção textual" (JAMESON, Fredric. O Inconsciente Político: a Narrativa como Ato Socialmente Simbólico. São Paulo: Ática, 1992. p. 28-9).

${ }^{119}$ No original: On the theory that what occurs is right. Any action is correct because it happens. What of that theory? Only if it works. I worry about images. Images are what things mean. Take the word image. It connotes soft, sheer flesh shimmering on the air, like the rainbowed slick of a bubble. Images connotes images, the multiplicity being an image. Images break with a small ping, their destruction is as wonderful as their being, they are essentially instruments of torture exploding through the individual's calloused capacity to feel powerful undifferentiated emotions full of longing and dissatisfaction and monumentality. They serve no social purpose. (p. 71). 
A aparência de aleatoriedade desse trecho se esvai numa leitura atenta. $\mathrm{O}$ trecho sucede o parágrafo, acima visto, em que Daniel desenvolve a ligação entre o destino das três mulheres de sua família. Aqui, Daniel expressa, da forma enigmática e cheia de associações inesperadas característica do tom do narrador em várias passagens do romance, sua preocupação com imagens e seu propósito social. O sentido desse trecho do romance já foi discutido por vários comentadores e parece, como outras passagens desse livro tão complexo, não ser passível de uma explicação inequívoca sem que seja relacionado a outras partes do livro.

Os primeiros períodos do trecho - "Baseado na teoria de que o que ocorre está certo, qualquer ato é correto por ter acontecido. E que tem a teoria? Só serve se funcionar." - parece contrariar o determinismo expresso pela teoria de que "o que ocorre está correto" e "qualquer ato é correto por ter acontecido" relativizando sua aplicação (“Só serve se funcionar”), ou seja, tal teoria só estará correta quando a ação que ocorrer estiver correta. Dessa forma, o ato confirma retroativamente a teoria, e não o contrário. Assim, essa teoria não funcionará quando a ação que ocorrer não estiver correta, de acordo com seus termos. Em outras palavras, ações que ocorrem podem estar erradas e demandarem análise. A proposição de que "qualquer ato é correto por ter acontecido" elimina qualquer tipo de intervenção crítica ou mudança, uma vez que o acontecimento confere, retroativamente, correção ao ato. O "ato correto", por ter acontecido, cria as condições de sua própria explicação e confirmação. Assim, temos uma aporia orwelliana, na qual o presente é reescrito para concordar com o que de fato aconteceu ("o ato é correto por ter acontecido").

Na sequência dessa passagem, vem a frase "Preocupo-me com imagens". Vindo logo após a imagem das três mulheres Isaacson acima comentada, essa frase coloca tal imagem em suspensão. A preocupação do narrador com imagens pode significar duas coisas: 1) imagens são frágeis e multiplicáveis, portanto são pouco úteis, ou mesmo nocivas, a qualquer esforço de representação ("Tomemos a palavra imagem. Sugere carne macia, nua, cintilando no ar como o arco-íris de uma bolha. Imagem sugere imagens, sendo a multiplicidade uma imagem. Imagens rompem-se com um leve estalido. Sua destruição é tão maravilhosa quanto sua existência...); 2) imagens são perigosas e potencialmente subversivas (“...São em essência instrumentos de tortura explodindo através da calejada capacidade do indivíduo para sentir fortes e difusas emoções plenas de anseio, insatisfação e amplitude.”). A última frase do trecho ("Não têm qualquer 
finalidade social”) contraria as duas leituras acima expostas: não servindo a nenhum propósito social, elas não podem ser nem nocivas nem subversivas, sendo apenas inócuas.

A sobreposição da imagem que sugere o engajamento político das mulheres Isaacson e do lacônico parágrafo que acabamos de ver ilustra o comportamento ambivalente da escrita nesse romance, reflexo da ambivalência do próprio narrador. $\mathrm{Na}$ perspectiva de Daniel, sua mãe e sua irmã são ambas vítimas de uma perigosa "falha de análise". Dessa forma, a narrativa confirma a imagem do livro de medicina e a loucura transmitida pelo coração de fato se manifesta, tanto na insistência de Rochelle em confiar na justiça (o que a levará à cadeira elétrica) como no suicídio de Susan. Desse modo, a imagem - construída pelo irmão de Susan a partir de uma fotografia - da herança política (ou da loucura, na perspectiva de Daniel) da família revela para ele parte do significado da tentativa de suicídio de sua irmã. Dessa forma, podendo fornecer pistas para o entendimento, as imagens carregam significado e função, mas, ao mesmo tempo, são construções e, como tais, são frágeis e passíveis de leituras alternativas. Esse vai-e-vem de sentido está mimetizado na aparente confusão do parágrafo que analisamos. Assim, esse parágrafo representa um microcosmo da instabilidade que marca todo o romance e cujas causas tentamos aqui encontrar.

Esse padrão de ambiguidades e instabilidade se repete em outros momentos da narrativa e mimetiza a desorientação política do narrador Daniel, que luta para entender o passado e o presente das trajetórias de sua família e da esquerda americana. O autoproclamado "Beacon of faith in Time of Persecution" ${ }^{120 "}$ tateia o sentido de sua experiência familiar e da história política do seu país, e o rastro dessa difícil caminhada fica registrado na forma - por vezes paradoxal, por vezes indefinida, por vezes enigmática - que a sua narrativa assume.

O ethos ambivalente do narrador como construção formal figura não a impossibilidade de qualquer narrativa coerente sobre a história política da Esquerda

\footnotetext{
${ }^{120}$ Daniel menciona o seu homônimo bíblico e sugere uma relação entre os dois decifradores de visões nas páginas 10,11 e 12 do romance (na versão em inglês). Não analisarei a metáfora bíblica - explícita já no título do romance - aqui por entender que esse estudo foge do que pretendo nessa tese. Para entender melhor o funcionamento dessa metáfora no romance, cf. AGILDO, João Rodrigo Lima. A crise da esquerda norte-americana em "The Book of Daniel”,', de E. L. Doctorow. 2006. 92f. Dissertação (Mestrado emEstudos Linguísticos e Literários em Inglês) Faculdade de Filosofia, Letras e Ciências Humanas, Universidade de São Paulo, São Paulo, 2006 - sobretudo o capítulo 2.
} 
americana - hipótese atraente para as correntes atuais da historiografia e da crítica literária que celebram a impossibilidade de uma versão única da História como conquista do pluralismo e da equivalência de todos os discursos - mas antes a própria necessidade da articulação dessa história. O ethos ambivalente do narrador Daniel joga a favor dessa articulação. Fosse Daniel um personagem dogmático, já certo de sua história e da história política que o livro articula, sua tese e sua narrativa terminariam em confortável fechamento e em uma inócua reconciliação com o real. A grandeza formal de The Book of Daniel está justamente na recusa desse conforto e o ethos ambivalente do narrador assim como a inconclusão do romance com seus três finais e a indefinição da tese de doutorado de Daniel - é o equivalente em forma literária da dificuldade, e, ao mesmo tempo, da necessidade, de uma articulação profunda das tensões políticas que marcam a história da Esquerda, particularmente nos Estados Unidos.

O depoimento do autor sobre a escolha do ponto de vista e do narrador do romance revela um imperativo formal imposto pelo trabalho de figuração de um conteúdo que recusa as formas mais tradicionais do romance histórico:

I started to write the book in the third person, more or less as a standard, past tense, third person novel, very chronologically scrupulous. And after one hundred fifty pages I was terribly bored. That was a moment of great despair in my life, because I thought if I could really destroy a momentous subject like this, then I had no right to be a writer. That moment, when I threw out those pages and hit bottom, was when I became reckless enough to find the voice of the book, which was Daniel. I sat down and put a piece of paper in the typewriter and started to write with a certain freedom and irresponsibility, and it turned out Daniel was talking, and he was sitting in the library at Columbia, and I had my book ${ }^{121}$.

O impasse a que a narrativa chega no momento da composição - lido aqui pelo autor como tédio - e que determina a explosão da forma tradicional do romance realista revela a necessidade de se buscar formas de narrar mais propícias a abrigar o redemoinho de tensões políticas, econômicas e sociais que caracteriza a história do século XX como uma "Era dos Extremos", nas palavras de Eric Hobsbawm ${ }^{122}$.

\footnotetext{
${ }^{121}$ TRENNER, op. cit., p. 62.

${ }^{122}$ The Age of Extremes - A History of the World, 1914-1991. New York: Vintage Books, 1996.
} 


\section{"Totally deprived of the right to be dangerous" - a esterilidade política de Daniel e o "castigo corporal como distinção de classe"}

Outro veio paradoxal da narrativa aparece na contraposição entre o radicalismo de algumas ideias do narrador - como os trechos de sua suposta tese sobre a punição corporal como distinção de classes - e sua descrença no potencial de mudança de ações revolucionárias. Daniel acredita-se vítima de permanente e irrevogável esterilidade política devido ao passado de sua família e à "criminalidade genética" que ele supõe ter herdado:

Seja qual for o ato político ou simbólico que eu execute em protesto ou desobediência, mal algum resultará para mim. Eu percebi. É exato. Sou totalmente privado do direito de ser perigoso. Se quisesse assassinar o presidente, a criminalidade de minha família, sua criminalidade genética, estaria estabelecida ${ }^{123}$. (p. 84)

"Totalmente privado do direito de ser perigoso", Daniel aparenta descrer de todo da capacidade de mudança do pensamento radical. Depois de relatar seu encontro com Artie Sternlicht ${ }^{124}$, em que entra em contato com as ideias revolucionárias desse

${ }^{123}$ No original: No matter what political or symbolic act I perform in protest or disobedience, no harm will befall me. I have worked this out. It's true. I am totally deprived of the right to be dangerous. If I were to assassinate the President, the criminality of my family, its genetic criminality, would be established. (p. 72).

${ }^{124}$ Misto de radical e performer, que, entre outras coisas, pretende ir a Washington para "exorcizar o Pentágono", fazê-lo "levitar com uma prece e um encantamento, tocando trombetas e atirando magias invisíveis às suas paredes (...) matá-lo com flores" e "subverter os Estados Unidos com imagens" (p. 154). A figura de Artie Sternlicht funciona na narrativa como uma espécie de eco de algumas das posições políticas radicais dos anos 60 - sobretudo a rejeição aos métodos da Velha Esquerda (Artie despreza a história do casal Isaacson, conforme foi apresentado anteriormente); a noção de que os modos de opressão capitalista tornaram-se difíceis de discernir em meio às tentações do consumo e da nuvem ideológica que torna tudo opaco; e uma nova ênfase em formas de luta simbólica. Ideias e sentimentos parecidos podem ser observados no relato que Norman Mailer faz de sua participação na Marcha ao Pentágono no livro The Armies of the Night, publicado em 1968, meses após o evento. No livro, Mailer analisa o simbolismo da Marcha e da figura do Pentágono ("... the true and high church of the military-industrial complex ... blind fivesided eye of a subtle oppression which had come to America out of the very air of the century"). A "sutil opressão" de que Mailer fala ecoa a percepção de Artie sobre as novas formas de opressão capitalista. Mailer descreve o real problema que deve ser enfrentado pela esquerda nos anos 60: "...how do you develop enough grace to capture a thief more graceful than yourself? Leninism 
personagem, Daniel tem a inspiração para um artigo sobre a dinâmica do pensamento radical:

Tenho uma ideia para um artigo. Se eu o escrever, talvez possa vendê-lo e ver meu nome em letra de imprensa. A ideia é a dinâmica do pensamento radical. A cada ciclo de pensamento radical ocorre um estágio de verdadeira excitação criativa, durante a qual são feitas as conexões. O radical descobre conexões entre os dados disponíveis e a responsabilidade fundamental. E finalmente faz uma conexão geral. A essa altura começa a perder seus seguidores. Não que tenha feito conexões erradas e sim porque fez uma conexão geral. Nada resta fora dessas conexões ${ }^{125}$. (p. 154)

O trecho destacado em negrito está mergulhado em paradoxo e ironia, tal qual a situação do radical, que, como Daniel explica, cria com seu pensamento as condições de sua própria destruição:

Nesse estágio a sociedade aborrece-se com o radical. Plenamente ligado em sua caracterização consegue o fundamento lógico da contra-revolução que lhe permite destruí-lo. Ao radical é concedida oportunidade para uma última descoberta - a conexão entre a sociedade e sua morte ${ }^{126}$. (p. 154)

was built to analyze a world in which all the structures were made of steel - now the sinews of society were founded on transistors so small Dragon Lady could hide them beneath her nail." (MAILER, Norman. The Armies of the Night - History as a Novel, The Novel as History. New York: Penguin, 1994, p. 179). Nesse trecho, o autor de Armies of the Night pronuncia a desconfiança da Nova Esquerda Americana em relação à utilidade dos métodos de análise da Velha Esquerda para a compreensão do mundo como ele se apresentava nos anos 60.

${ }^{125}$ No original: I have an idea for an article. If I write it maybe I can sell it and see my name in print. The idea is the dynamics of radical thinking. With each cycle of radical thought there is a stage of genuine creative excitement during which the connections are made. The radical discovers connections between available data and the root responsibility. Finally he connects everything. At this point he begins to lose his following. It is not that he has incorrectly connected everything, it is that he has connected everything. Nothing is left outside the connections.(p. 140).

${ }^{126}$ No original: At this point society becomes bored with the radical. Fully connected in his characterization it has achieved the counterinsurgent rationale that allows it to destroy him. The radical is given the occasion for one last discovery - the connection between society and his death. (p. 140). 
Tomando à risca a tese de Daniel, teríamos uma aporia ${ }^{127}$ : o radical, criando, com seu pensamento, a racionalidade contrarrevolucionária que permite sua destruição, estaria preso a uma fita de moébius. Aqui, novamente, o padrão de ambiguidades da narrativa é manifesto. Vindo após o relato de seu encontro com Artie, o revolucionário, essa ideia de artigo poderia soar como um comentário cínico de Daniel sobre o papel dos radicais na sociedade. Uma leitura centrada na contiguidade entre o episódio do encontro com Artie e a ideia do artigo sustentaria essa hipótese. No entanto, se considerarmos outros elementos da narrativa - como a tese de Daniel sobre o castigo corporal como distinção de classe; as variadas análises históricas, políticas e sociais de aspectos da vida americana, sobretudo a leitura que o narrador faz da Disneylândia; a mudança, ainda que superficial e hesitante, do comportado pós-graduando de Colúmbia Daniel Lewin para o rebelde Daniel Isaacson - podemos cogitar certo grau de ironia nessa ideia de artigo.

A noção de um ciclo no qual o radical estabelece conexões até chegar a derradeira descoberta - "a conexão entre a sociedade e sua morte" - é coerente com a tese do castigo corporal como distinção de classe. Daniel oferece vários exemplos históricos de atos bárbaros praticados contra aqueles que ameaçam, discordam ou ofendem a ordem dominante. Estes dissidentes são, invariavelmente, de classes sociais inferiores, e a brutalidade da punição é proporcional à estatura social do condenado - daí a noção do castigo como distinção de classe. Ambas as ideias de Daniel sobre as maneiras como a sociedade dominante elimina seus dissidentes (expressas no artigo idealizado e na tese) se aplicam à morte de seus pais. Num dos exemplos históricos pesquisados pelo doutorando Daniel, o vínculo com a situação de seus pais se anuncia de forma clara:

Matar e Esquartejar. Esta forma particular de execução era a predileta da monarquia inglesa para com todos em geral, exceto o círculo aristocrático mais íntimo, a quem era concedida a dignidade da simples decapitação. Para todos os demais o método funcionava da seguinte maneira: o transgressor era enforcado e a corda cortada antes que estivesse morto. Em seguida era emasculado, estripado e as entranhas queimadas diante de seus olhos. Se o executor fosse misericordioso, o coração era então retirado do corpo, mas de qualquer maneira, o ato extremo do ritual era então executado - $\mathrm{o}$ esquartejamento do corpo em quatro partes, que eram atiradas aos cães. Traição era o crime costumeiro para este tipo de punição,

\footnotetext{
${ }^{127}$ Semelhante àquela apontada acima no trecho "Baseado na teoria de que o que ocorre está certo, qualquer ato é correto por ter acontecido. E que tem a teoria? Só serve se funcionar."
} 
sendo a sua definição determinada pelas cortes do rei e para sua real conveniência ${ }^{128}$. (p. 85)

Traição é justamente o crime pelo o qual Paul e Rochelle foram condenados, e podemos dizer hoje depois das diversas revisões que o caso Rosenberg vêm suscitando ao longo dos anos - a condenação era vista como conveniente e necessária por muitos membros da classe dominante, como explicita o Tio Sam, personagem de Robert Coover em The Public Burning, cujas palavras sobre o julgamento repito aqui: "This is to be a consecration, a new charter of the moral and social order of the Western World" (p. 91).

Além do aspecto ideológico do caso - sobre o qual Daniel demonstra ter grande consciência, como prova, entre outros, o longo segmento do livro intitulado "The True History of the Cold War" - a condição de classe dos Isaacson não é ignorada como parte da equação que resultou na condenação de Paul e Rochelle. As memórias de Daniel sobre sua infância são repletas de lembranças da pobreza da família, desde as dificuldades financeiras do negócio de Paul até o hábito de Rochelle de comprar roupas grandes demais para que as crianças "crescessem dentro delas". Daniel lembra esse aspecto da família ignorado pela cobertura da imprensa sobre o julgamento:

Minha mãe tomou Susan nos braços, lágrimas escorrendo-lhe pelo rosto. Cada peça de mobiliário da casa fora, em determinado momento de sua vida, sua maior preocupação. Fizera cada cortina, esfregara e polira cada centímetro do chão daquela velha barraca de madeira cheia de goteiras, onde morávamos. Haverá algum jornalista que escreveu a respeito do julgamento mencionando a pobreza dos Isaacsons, a feiura de sua casa com mobília descartada do Exército da Salvação, pintura feita por amadores, papel de parede manchado nos pontos em que a chuva penetrava junto à porta? ${ }^{129}$ (p. 124)

${ }^{128}$ No original: Drawing and Quartering. This particular form of execution was favored by English monarchic government against all except the aristocratic inner circle which was allowed the dignity of simple beheading. For everyone else the method worked like this: the transgressor was hanged and cut down before he was dead. Then he was emasculated, disemboweled and his entrails were set on fire in front of his eyes. If the executioner was merciful the heart was then removed from the body, but in any case, the final act of the ritual was then performed, a hacking of the body into four parts, the quarters then being thrown to the dogs. Treason was the usual crime for this punishment, its definition being determined by the King's court for the King's convenience. (pp. 73-74).

${ }^{129}$ No original: My mother stood with Susan in her arms and tears coming down her cheeks. Every piece of furniture in the house had been, in some moment of her life, her utmost concern. She had made every curtain, she had scrubbed and polished every inch of floor. This old, leaky, wooden shack we lived in - and what newspaperman who wrote about the trial ever said a thing about 
Assim, a condição de classe socialmente inferior e a acusação de traição aproximam o casal Isaacson dos súditos ingleses trucidados pela monarquia apropriadamente relembrados na pesquisa de Daniel. Histórias de perseguição a dissidentes de várias épocas aparecem frequentemente nas reflexões de Daniel. Suas memórias são marcadas por tais momentos, sobretudo pelo traumático julgamento de seus pais, mas também por episódios históricos como os ataques a militantes de esquerda antes, durante e depois do show de Paul Robeson, em Peekskill, Nova York. Agachado entre os bancos do ônibus e protegido por sua mãe, o menino Daniel presencia um gesto heroico de seu pai: Paul se adianta até a porta do ônibus - que estava para ser virado - e, na tentativa de sair para chamar a atenção de policiais, tem seu braço quebrado pelos furiosos manifestantes sob gritos de “...kike, commie bastard, jew commie, red... Jew. Commie. Red. Nigger. Bastard. Kike. Nigger-lover. Red. Jew bastard” (p. 49).

Hoje, sabe-se do impacto negativo que a perseguição política à Esquerda, promovida com mais intensidade nos anos 50, deixou no ânimo de ação de seus militantes. No mapeamento político do romance, essa perseguição é central, uma vez que a trama se desenrola em torno de uma execução que foi em grande parte determinada por um clima de animosidade contra o pensamento radical. Daniel vincula sua esterilidade política ao ato de violência inaugural de sua história: a execução de seus pais. Sua tese sobre a história do castigo corporal como distinção de classe é uma tentativa de entender essa violência na narrativa maior do processo histórico.

\section{O sacrifício revolucionário e a herança soviética: Daniel relendo a História}

the Isaacsons' poverty, the shabbiness of their home with its broken-down Salvation Army furniture and castoffs, and amateur paint jobs, its stained wallpaper where the rain soaked through the front door. (p. 113). 
Daniel relembra vividamente o episódio do ato heroico de seu pai e o retrata de forma quase poética e sentimental. Mas a justaposição desse retrato com a menção à figura de Bukharin traz tons de ironia ao "sacrifício revolucionário planejado" e "calmamente vivido" de Paul. Vejamos o trecho em que essa ligação entre a história da família Isaacson e a História da Revolução Russa é feita:

Mas eu jamais esquecerei a tranquila ferocidade de sua decisão ao dobrar os óculos contra o peito e entregá-los a Mindish. Não poderia esquecer o compromisso naqueles olhos absurdamente nus; ou no gesto, o sacrifício revolucionário planejado, calmamente vivido...

Bukharin apresentou uma defesa muito interessante no seu julgamento, durante o expurgo de 1938. Confessou-se culpado e insistiu em afirmar por diversas vezes sua responsabilidade no total de crimes cometidos pelo bloco de réus "direitistas e trotskistas", dos quais era considerado líder. Concordou, veemente, ser culpado de conspiração, traição e contra-revolução. E, tendo-o reconhecido, foi uma exceção, no decorrer do julgamento, a cada acusação específica feita contra ele. Pressionado para depor segundo o especificado, conseguiu, ainda assim, indicar com sugestões peculiares, características das vozes soviéticas sob o governo de Stalin, que ele e a Rússia estavam sendo vitimados. E que vantagem resultaria para ele senão o fato de se ter transformado num herói de romance e na imagem de melancólica nobreza dos sovietologistas $?^{130}$ (p. 63)

Numa brusca virada irônica, bem característica do estilo de Daniel, o humor do texto passa da admiração pelo gesto heroico de Paul à percepção da inutilidade desse gesto. Bem ao estilo iconoclasta dos anos 60 e avesso à herança soviética tão cara aos comunistas dos anos 30, Daniel evoca um dos episódios incômodos da História da Revolução Russa: o Grande Expurgo ou Julgamentos de Moscou. Com certeira pontada,

\footnotetext{
${ }^{130}$ No original: But I could not forget the calm ferocity of his decision, folding his glasses against his chest and handing them to Mindish. I could not forget the commitment in his absurdly naked eyes; or in his act, the quality of calmly experienced, planned revolutionary sacrifice. / Bukkarin provided the most interesting defense of the Purge Trial of 1938. He pleaded guilty and went out of his way on several occasions to affirm his responsibility for the sum total of crimes committed by the defendant block of "rightists and Trotskyites," of which he was considered a leader. He vehemently agreed that he was guilty of conspiracy, treason, and counterrevolution. And having agreed, he took exception during the trial to every specific charge brought against him. Under duress to testify on cue, he nevertheless contrived to indicate with the peculiar kind of overtone characteristic of Soviet voices under Stalin, that he and Russia as well were being victimized. And what good did it do him except that he became a hero in a novel and an image of sorrowful nobility to Sovietologists. (p. 52).
} 
Daniel reabre uma ferida que "criou uma crise de consciência para a Esquerda americana $^{131}$,

A transição do tom memorialístico, quase sentimental, com que Daniel relembra o ataque de Peekskill e a reação heroica de seu pai para o tom frio e distanciado do discurso acadêmico que segue é ilustrativa do estilo ambivalente do narrador. Significativamente, no trecho ensaístico que sucede o episódio Peekskill, Daniel, numa incontinência de episódios dramáticos e decisivos da História Russa, escreve praticamente um resumo dos fatos mais marcantes da Revolução Russa, que vai ganhando intensidade até chegar a uma lista de fatos contraditórios (e mesmo constrangedores e inexplicáveis para a esquerda) da história da Revolução e culmina na afirmação - bem ao espírito dos anos 60 - de que "revolução alguma é traída e sim cumprida" (p. 64), seguida de uma ruptura com o texto ensaístico e um momento metaficcional, uma "Nota ao Leitor”. A centralidade dessa passagem para a compreensão da ambivalência que venho destacando no romance recomenda a leitura do trecho inteiro, o que farei dividindo a passagem em partes, a primeira das quais vai a seguir:

Podemos dizer a respeito de Stalin, por sua vez, que os grandes julgamentos de 1936 a 1938, assim como milhares de extermínios menos organizados e executados sob sua égide, refletiram sua decisão de transformar Hitler num aliado. Kennan diz que Stalin precisava certificar-se de que não haveria oposição a prejudicá-lo na sua impopular medida, conhecida no mundo como Tratado de Não-Agressão de 1939. Bukharin e vários dos outros acusados eram antifascistas. Fossem quais fossem as razões de Stalin para desejar fazer de Hitler um aliado - desespero de promover os interesses russos junto aos países do Ocidente, ou vivo impulso no sentido da hegemonia fascista-soviética, ou necessidade de tempo para preparar o país para a guerra com Hitler, que ele sabia iminente (mas neste caso por que liquidar os mais importantes chefes soviéticos?) - pode-se dizer que esta jogada, a Grande Experiência Socialista, com todas as outras manobras políticas da Rússia soviética na década de trinta, foi declarada sobre a primazia da nação-estado, o adiamento dos sonhos dos marxistas e o caráter sacrificável do indivíduo $^{132}$. (pp. 63-64)

131 "Thus the Moscow trials created a crisis of conscience for the American Left. Although many could not bear the burden of truth, a number of important writers broke with the Popular Front and publicly condemned the Soviet government" (DIGGINS, John Patrick. The Rise and Fall of the American Left. New York, London: W.W. Norton \& Company, 1992, p. 186).

${ }^{132}$ No original: We may say of Stalin, in turn, that the show trials of 1936 to 1938 as well as the thousands of less structured exterminations carried out under his aegis reflected his determination to make an ally out of Hitler. Kennan says Stalin had to make sure there would be 
Essa passagem remete o leitor de volta à biblioteca da Universidade de Colúmbia, onde Daniel escreve sua tese/relato/romance/biografia/devaneio. Aqui, temos a voz do pós-graduando, que, embora nunca fale claramente sobre sua pesquisa e sobre sua área de estudos, podemos supor ser estudante de história ${ }^{133}$. O trecho acima demonstra uma segurança de raciocínio e exposição próprias de alguém que tem familiaridade com o assunto em discussão. As citações de outros autores (Kennan e, mais adiante, E. R. Carr) - ambos conhecidos estudiosos da história da União Soviética ${ }^{134}$ - enfatiza o caráter acadêmico do discurso de Daniel nesse trecho.

Há, nesse texto acadêmico de Daniel, uma potencial confusão epistemológica no emprego de fontes tão ideologicamente antagônicas como Kennan e Carr - um, conselheiro da Casa Branca e ideólogo de uma política de "contenção" da União Soviética que deu origem à Guerra Fria; o outro, publicamente simpático ao período da Revolução Russa até 1929, que ele retratou na sua História da Revolução Russa. A confusão seria ainda maior se considerássemos o fato de que Carr, a partir dos anos 30, passa a ser uma figura controversa, que rejeita o socialismo e o marxismo, mas oferece leituras que

no opposition to fault him in his unpopular move known to the world as the Non-Aggression Treaty of 1939. Bukharin and many of the other defendants were anti-Fascists. Whatever Stalin's reasons for wanting to make an ally of Hitler - whether in despair of promoting Russian interests with the Western countries, or out of a keen impulse toward a Fascist-Soviet hegemony, or because he needed time to prepare his country for war with Hitler which he knew was imminent (but if this was so, why did he kill his ranking army officers?), it can be said that this, like every major 1930's policy move of Soviet Russia the Great Socialist Experiment was predicated on the primacy of the nation-state, the postponement of Marxist dreams, and the expendability of the individual. (p. 53).

${ }^{133}$ Os poucos autores que tentaram encontrar o tema da tese de Daniel no romance concordam que se trata de tese em História. A única exceção que encontrei a essa ideia foi a suposição de Theophilus Savvas (American Postmodernist Fiction and the Past, p. 126) de que Daniel escreve uma "doctoral dissertation in literature", tese que julgo inverossímil.

${ }^{134}$ George Frost Kennan (1904 -2005) foi historiador e conselheiro político da Casa Branca para assuntos soviéticos. Inspirador da Doutrina Truman e da política externa americana de contenção da, segundo ele, natureza expansionista da União Soviética. Assim, Kennan foi figura chave na emergência da Guerra Fria. Considerando-se que a narrativa no romance é interrompida em 1968, Daniel pode estar fazendo menção a um dos seguintes livros de Kennan sobre a relação entre a Rússia e o Ocidente: Russia, the Atom, and the West (1958), Russia and the West under Lenin and Stalin (1961).

Edward Hallett Carr (1892 -1982) foi um historiador britânico de tendência marxista. Escreveu uma História da União Soviética em 14 volumes e o livro What is History (New York: Random House, 1961), em que rejeita métodos historiográficos tradicionais. 
explicam - e, para alguns, quase justificam - ações polêmicas do regime soviético, como poderemos perceber na continuação da passagem aqui analisada, na qual Daniel, após longa citação de Carr, conclui: "Este insight de Carr é útil à compreensão de tais momentos de agonia diante do socialismo mundial...” (p. 64). Sintomaticamente, essa confusão de referências acadêmicas alude à ambivalência do narrador, também ele à deriva num oceano de referências, sentimentos, fatos, interpretações, mentiras, contradições etc.

A citação de Carr evoca as discussões historiográficas que servem de guia para muitas das análises dos romances de Doctorow - sobretudo Ragtime, como veremos no próximo capítulo. Com seu livro What is History? (1961), Carr se torna um dos precursores da "nebulosidade intelectual" que começa "a pairar sobre a paisagem historiográfica dos anos 70 ${ }^{135}$ ". Ilustrativo do espírito dessa obra e da historiografia proposta por Carr é o trecho a seguir:

The absolute in history is not something in the past from which we start; it is not something in the present, since all present thinking is necessarily relative. It is something still incomplete and in the process of becoming - something in the future toward which we move, which begins to take shape only as we move towards it, and in the light of which, as we move forward, we gradually shape our interpretation of the past ${ }^{136}$.

O postulado de que "todo pensamento do presente é necessariamente relativo" lembra a "natureza paradoxal do conhecimento historiográfico" em Croce ${ }^{137}$ que, como explica Hayden White, acontece quando

A consciência histórica avança porque pode contar com uma nova fase filosófica e teórica, mas, paradoxalmente, descobre-se que a prova de seu avanço reside no reconhecimento de que a consciência nada pode dizer a respeito da época em que realiza esse avanço ${ }^{138}$.

\footnotetext{
${ }^{135}$ HOBSBAWM, Eric. Sobre História. São Paulo: Companhia das Letras, 1998, p. 10.

${ }^{136}$ CARR, Edward. What is History? New York: Random House, 1961, p. 161.

${ }^{137}$ WHITE, Hayden. Meta-História: A Imaginação Histórica do Século XIX. São Paulo: Editora da Universidade de São Paulo, 2008, p. 402.

${ }^{138}$ Idem, p. 404.
} 
Retornando à primeira parte da passagem que aqui analiso, devemos nos lembrar de que o tema predominante desse trecho - o pacto de não-agressão assinado por Stalin e Hitler - é um dos "momentos de agonia diante do socialismo mundial" (p. 64) mais agudos da história da Esquerda nos Estados Unidos. Diggins comenta o impacto desse acordo na consciência da Esquerda americana:

During the height of the Popular Front, Russian stood for all that was good, rational, and progressive, and Germany for all that was evil, barbaric, and reactionary. The Nazi-Soviet pact killed that dream and, as W. H. Auden expressed it, "the clever hopes expired of a low dishonest decade ${ }^{139}$ ".

A posição de Daniel a respeito do pacto expressa a descrença em relação à "experiência soviética" consolidada a partir do chamado "Discurso Secreto" de Nikita Krutchev no Vigéssimo Congresso do Partido Comunista, em $1956^{140}$. Essa descrença é visível na objeção que Daniel faz - entre parênteses, como se, timidamente, invadindo o discurso sóbrio e imparcial do estudioso - a uma das tentativas de explicação da assinatura do pacto de não-agressão: “...necessidade de tempo para preparar o país para a guerra com Hitler, que ele [Stalin] sabia iminente (mas neste caso por que liquidar os mais importantes chefes soviéticos?)". A frase entre parênteses indica desconfiança em relação à tese de que Stalin tenha assinado o pacto como uma estratégia para ganhar tempo

\footnotetext{
${ }^{139}$ DIGGINS, op. cit., p. 186.
}

${ }^{140}$ James Weinstein explica o impacto desse evento de 1956 na influência dos comunistas na Esquerda Americana: "By 1955, Communists and those close to the party's various front organizations became increasingly aware that they had no direction - no vision of a socialist United States other than that provided by Soviet life. And, of course, the party had no long-range strategy aimed toward a socialist transformation. This had been true for a long time, but it had never been so close to the surface of party life and so acutely apparent to many party members. / This growing awareness was well advanced by 1956 when the left was struck by Nikita Khrushchev's revelations about Stalinist terror (at the Twentieth Congress of the Communist Party of the Soviet Union), and then by the Russian army' s invasion of Hungary to put down a popular revolt. Now, in addition to lacking a public vision of socialism, the party's private vision was shattered. The combination of a steady decline of party influence, post-McCarthy aimlessness, and disillusionment over the Twentieth Congress and Hungary reduced the Communists to the impotence of other socialist sects. For the first time since 1900 American left-wing socialists were on their own - not only without a coherent theory or vision but also without an organized movement." (WEINSTEIN, op. cit., pp. 112-113). 
a fim de preparar o exército soviético contra Hitler. Também indica a necessidade - e, ao mesmo tempo, a dificuldade - de redimir esse episódio do passado soviético a fim de preservar a Revolução Russa como inspiração para a luta revolucionária em outros países. A inexistência desse modelo é um elemento determinante da desorientação política atual e sua derrocada é fundamental para o mapeamento que Daniel faz nessa parte do romance.

Ao final da passagem, Daniel explicita sua posição - já insinuada na objeção acima mencionada - em relação à política do estado soviético nos anos $30^{141}$.

O episódio do pacto de não-agressão - além de trazer desilusão para parte da Esquerda e munição para a Velha Esquerda anti-stalinista dos anos $30^{142}$ - acabou iniciando um processo que culminou em um acirramento da perseguição política ao PC americano:

Roosevelt's growing concern about Nazi Germany should have brought US-Soviet cooperation, especially after the German attack on Poland in September 1939. But a secret Nazi-Soviet deal allowed Moscow to occupy eastern Poland and the Baltic states. In November the Soviets attacked Finland. This confirmed for many the cynical nature of a leadership whose vicious qualities were made evident in the show trials, imprisonment and widespread executions of the late 1930s. When the American Communist Party supported the Nazi-Soviet Pact, the Roosevelt administration imprisoned its leader, Earl Browder, for passport fraud. In addition, the Americans introduced tough regulations on affiliation to foreigner organizations, forcing the party in 1940 to end its formal membership of the Comintern ${ }^{143}$.

A relação conflituosa da geração de 60 , a qual cresceu sob a influência da polarização ideológica dos anos de Guerra Fria, com os eventos da Revolução Russa na fase stalinista - latentes nas passagens em que Daniel trata dessa história, como estamos vendo - pode ser percebida também no tom da passagem acima reproduzida quando se fala sobre “... a natureza cínica de uma liderança cujas qualidades viciosas foram deixadas

\footnotetext{
${ }^{141}$ Retomemos: “...pode-se dizer que esta jogada, a Grande Experiência Socialista, com todas as outras manobras políticas da Rússia soviética na década de trinta, foi declarada sobre a primazia da naçãoestado, o adiamento dos sonhos dos marxistas e o caráter sacrificável do indivíduo." (p. 64)

${ }^{142}$ Cf. DIGGINS, op. cit., p. 183.

${ }^{143}$ HOPKINS, Michael F. The Cold War. London: Thames \& Hudson, 2011, p. 20.
} 
evidentes nos julgamentos de Moscou, prisões e execuções generalizadas do final dos anos $30 "$.

O confronto de Daniel com os fantasmas da história da Rússia revolucionária é fundamental para o mapeamento das posições de esquerda nos Estados Unidos que culminaram no desencantamento de uma geração - figurado no personagem Daniel - com o passado da esquerda mundial. Michael Denning sugere a importância dessa história para a compreensão da atmosfera antiutópica em que vivemos hoje:

...the difficulties we experience imagining our way out of the dichotomies of ruthless global capitalism and a failed, totalitarian state socialism are neither technical nor economic. They stem from our inability to imagine the conditions of possibility of a truly free society of autonomous, yet cooperative, individuals. While Heidegger and Marcuse may have identified technological domination as a culprit, the specificity of the history of socialism itself must be reckoned as an important component of this profoundly pessimistic antiutopianism that has gripped contemporary culture ${ }^{144}$.

Dessa forma, o mapeamento dos sentimentos da Esquerda Americana em relação aos momentos decisivos da História da Revolução Russa - referência incontornável para o pensamento de esquerda - dá ao romance um poder de diagnóstico admirável do atual estado de desorientação do pensamento revolucionário. O solipsismo radical dos irmãos Homer e Langley Collyer, como veremos no terceiro capítulo, é uma extrapolação do ambiente antiutópico cuja gestação está representada no universo político de The Book of Daniel.

\section{Mapeando as posições de esquerda nos Estados Unidos: Duas leituras da História da Revolução Russa}

\footnotetext{
${ }^{144}$ DENNING, Michael. Review of Marxism in the United States: Remapping the History of the American Left. In: International Labor and Working-Class History, No. 34, Religion and the Working Class (Fall, 1988), pp. 118-120. Cambridge University Press on behalf of International Labor and Working-Class, Inc http://www.jstor.org/stable/27671785 (acessado em 01/06/013).
} 
O choque de gerações fica evidente no confronto das visões de Daniel e de Paul sobre o pacto de não-agressão. O pai de Daniel compartilha com sua geração um olhar da União Soviética como modelo de sociedade ${ }^{145}$ e procura defender esse modelo com todas as armas do raciocínio e do arsenal de ideias políticas de que dispõe. Esse esforço fica explícito num trecho do roteiro do filme Daniel ${ }^{146}$ - também escrito por Doctorow - na qual Paul acompanha com entusiasmo, como vemos no filme, uma defesa do pacto de não-agressão:

EXT. PAINE LODGE. DAY. SUMMER '39

The dining room of Paine Lodge, a Marxist summer campresort. Dinner is over but everyone has remained at their tables to listen to a speaker who stands at one end of the room.

SPEAKER ... and those who excused the infamous Munich betrayal are loudest in their condemnation of the nonaggression pact. And why? Because by forcing Germany to sign this pact, with one stroke of the pen the Soviet Union overturns the design of Western imperialists. Hitler's war aims are contained in the East and mankind is diverted from the abyss of darkness and destruction.

At the back of the room, a group of young waiters and waitresses, listening intently. In the group are PAUL and ROCHELLE.

But the reactionaries will defame the Soviet Union no matter what, my friends, of that you may be sure. You will hear much criticism of Russia, and some of it will come disguised as sweet reasonableness... (...)

But don't be fooled! Don't be fooled, comrades. The arguments for the nonaggression pact are inescapable once you apply thought to the matter. The Soviet Union is the only socialist nation in the

145 "While the American economy stagnated and millions of people desperately sought work, the Russians were in the midst of their five-year plans, had full employment, and were making rapid strides toward industrialization. It was difficult indeed in the 1930s to think of oneself as a revolutionary without identifying with the living embodiment of socialism triumphant." (WEINSTEIN, op. cit., p. 73).

${ }^{146}$ O filme Daniel (1983) foi dirigido por Sidney Lumet. Das adaptações feitas de seus romances para o cinema (Ragtime, Welcome to Hard Times e Daniel), é a preferida de Doctorow e, para o autor, a que mais se aproxima da obra que a inspirou: "Daniel, of the three films, is the most faithful. Daniel is a novel-film; it has certain novelistic structure to it. And since I wrote the screenplay to it, I think it's reasonably faithful to the book, probably the most faithful of the three films. While we made some critical mistakes, I like that film very much."(In: MORRIS, Christopher D. (ed.) Conversations with E.L. Doctorow. Jackson: University Press of Mississippi, 1999, p.108). 
world, and she has done something for the world which the world will someday understand, if it doesn't already! ${ }^{147}$

$\mathrm{Na}$ continuação da longa passagem do romance que estamos aqui analisando, Daniel oferece uma explicação de E. H. Carr para o predomínio de Stalin e da tese do "socialismo num país só" sobre os "elementos internacionais e ocidentais do bolchevismo", representados por figuras como Trotsky. Para Carr, conforme Daniel nos informa, Stalin se apoia na tradição nacional russa para rechaçar tais elementos internacionais e com isso ajuda a acordar "as forças ocultas do passado russo - autocracia, burocracia, conformidade política e cultural”, que dão à revolução uma "estreita moldura nacional". Vejamos o argumento, atribuído ao historiador E. H. Carr, explicado por Daniel:

E. H. Carr sugere que o gênio de Stalin residiu na sua recuperação do nacionalismo russo, adormecido sob o ocidentalizado e internacionalista Lenine. "Socialismo num só país", foi a afirmação feita por Stalin, do orgulho feroz, e sublinhada de inferioridade face à histórica e trágica hostilidade ocidental para com a atrasada Rússia.

"O marxismo internacional e o socialismo plantados no solo russo e entregues a si mesmos encontraram o seu caráter internacional exposto à constante infiltração e solapamento da tradição nacional russa, que se supunha houvessem destruído em 1917. Dez anos mais tarde, quando Lenine já estava morto, os líderes que haviam representado da maneira mais conspícua os elementos internacionais e ocidentais do bolchevismo - Trotsky, Zinoviev e Kamenev, para não mencionar figuras secundárias como Radek, Krasin e Rakovsky - haviam todos desaparecido; o manso e sugestionável Bukharin em breve os seguiria. As forças ocultas do passado russo - autocracia, burocracia, conformidade política e cultural - vingaram-se, não destruindo a revolução, mas prendendo-a a si mesmas, a fim de executá-la numa estreita moldura nacional..."148 (p. 64)

${ }^{147}$ DOCTOROW, E. L. Three screenplays.Baltimore: Johns Hopkins University Press, 2003, pp. 29-30.

${ }^{148}$ No original: E. H. Carr suggests that the genius of Stalin was in his recovery of Russian nationalism, dormant under the westernized, internationalist Lenin. "Socialism in one country" was Stalin's affirmation of his country's fierce inferiority hounded pride in the face of the historic, tragic, western hostility towards Russia. / "International Marxism and international socialism, planted in Russian soil and left to themselves, found international character exposed to the constant sapping and mining of the Russian national tradition which they had supposedly vanquished in 1917. Ten years later, when Lenin was dead, the leaders who had most conspicuously represented the international and western elements in Bolshevism - Trotsky, Zinoviev, and Kamenev, not to mention minor figures like Radek, Krasin, and Rakovsky - had all 
O uso das aspas sugere a citação direta do texto de Carr por Daniel, o qual, estando na biblioteca no momento em que escreve o texto que lemos, provavelmente consulta as obras que menciona enquanto produz o mosaico derivado da sua tentativa de tese. Nas minhas pesquisas dentro da obra de Carr, não pude comprovar - dada a vastidão de tal obra - se a citação que Daniel usa é verdadeira ou inventada por Doctorow. O que importa aqui é que o uso das aspas indica a pretensão de que a citação seja lida como verdadeira pelo leitor, o que adiciona mais um ingrediente à salada epistemológica que Daniel escreve.

Na continuação da passagem, Daniel, de forma um tanto determinista, lê o argumento de Carr sobre a influência da tradição nacional russa nos rumos da Revolução como explicação para os "momentos de agonia diante do socialismo mundial", que ele reaviva para o leitor:

... a recusa soviética de apoiar a coalizão da esquerda comunista na Alemanha, que talvez tivesse impedido a ascensão de Hitler ao poder; a traição soviética à causa republicana na Espanha (muitas das vítimas do expurgo eram veteranos da campanha espanhola); o uso cínico da frente popular e da segurança coletiva como elementos da diplomacia soviética; e o pacto de não-agressão ${ }^{149}$. (p. 64)

Na continuação, Daniel explicita sua descrença em ações revolucionárias:

Assim, para os críticos que veem em Stalin o "Gengis Khan" de Bukharin, ou o paranoico que, conforme lamentavelmente confessa hoje a liderança soviética, ele foi, dizemos: revolução alguma é traída e sim cumprida ${ }^{150}$. (p. 64)

disappeared; the mild pliable Bukharin was soon to follow. The hidden forces of the Russian past - autocracy, bureaucracy, political and cultural conformity - took their revenge not by destroying the revolution, but by harnessing it to themselves in order to fulfill it in a narrow national framework..." (pp. 53-54).

${ }^{149}$ No original: the Soviet refusal to support the Communist-left coalition in Germany that might have prevented Hitler's rise to power; the Soviet betrayal of the Republican cause in Spain (many of the purge victims were veterans of the Spanish campaign); the cynical use of the popular front and collective security as elements in Soviet diplomacy; and the non-aggression pact. (p. 54).

${ }^{150}$ No original: Thus, to those critics who see in Stalin the "Genghis Khan" he was called by Bukharin, or the extreme paranoid he is sorrowfully admitted to have been by today's Soviet leadership, we must say: no revolution is betrayed, only fulfilled. (p. 54). 
Nesse trecho de grande pessimismo político, Daniel não descarta apenas o socialismo real na União Soviética como uma promessa revolucionária não realizada, mas a própria ideia de revolução. Essa profisssão de ceticismo do narrador é seguida pelas palavras "Termidor. Daniel Termidor...", vocábulo temível em qualquer léxico revolucionário. Aqui, o "termidor” de Daniel é decretado contra as revoluções.

Como Daniel vem falando do regime de Stalin nas linhas anteriores, presumisse que sua referência imediata seja ao Termidor Soviético, que foi descrito por Trotsky como a vitória da burocracia sobre a oposição de esquerda, o partido bolchevique e o programa de Lênin:

A burocracia não venceu unicamente a Oposição de Esquerda, venceu igualmente o partido bolchevique, venceu o programa de Lênin, que apontava como perigo principal a transformação dos órgãos do Estado "de servidores da sociedade em senhores da sociedade". A burocracia venceu todos os seus adversários - a oposição, o partido de Lênin - não com a ajuda de argumentos e de ideias, mas esmagando-os sob o seu próprio peso social. A retaguarda de chumbo mostrou-se mais pesada que a cabeça da revolução. Esta é a explicação do Termidor soviético. (...) ...Termidor soviético, que deu a uma burocracia pouco culta uma completa independência, preservada de qualquer controle, e às massas a famosa diretiva do silêncio e da obediência, a causa incontestável da sobrevivência da velha barbárie russa ${ }^{151}$.

Sabedor do espinhoso universo das referências soviéticas da Esquerda, Daniel faz referência a Trotsky ao mencionar o Termidor, para logo em seguida relembrar o episódio de Kronstadt (“...e que dizer de Kronstadt? Não devemos esquecer KRONSTADT!”, p. 64) no qual Trotsky, em 1921, comandou a supressão de um levante de marinheiros anarquistas. Aqui, nessa referência de Daniel, o próprio conceituador do termo Termidor Soviético é mostrado como comandante impiedoso de um ataque contra dissidentes de outra linha de pensamento de esquerda. Assim, escrutinando a história da Revolução Russa, Daniel vai desenrolando um novelo de violência e traições que constitui a maneira como essa história é vista a partir das revisões iniciadas em 1956. Do ponto histórico de

${ }^{151}$ TROTSKY, Leon. A Revolução Traída. São Paulo: Global Editora, 1980. http://www.marxists.org/portugues/trotsky/1936/revolucaotraida/index.htm (acessado em 10/04/2013). 
onde Daniel vê essa história, essa é a visão que ele tem, uma visão bem diferente daquele que seu pai - e sua geração - tinham da União Soviética.

Nessa longa passagem que venho aqui analisando, Daniel sintetiza os dilemas de interpretação histórica mais pungentes da Velha esquerda americana dos anos 30: os julgamentos de Moscou; o julgamento e execução de Bukharin; o Pacto de não-agressão assinado com Hitler; a recusa soviética em apoiar os comunistas na Alemanha; a participação dos comunistas na Guerra Civil Espanhola ${ }^{152}$. A conclusão com a referência ao Termidor Soviético (referência favorável à figura de Trotsky) logo seguida da lembrança do episódio de Kronstadt (desfavorável à Trotsky) adiciona ambivalência ao já complicado cenário das referências soviéticas da Esquerda americana.

Diggins compara a imagem heroica de Trotsky para a Velha esquerda antistalinista à imagem heroica de Lênin para a geração que ele nomeia como "Esquerda Lírica" ${ }^{153}$. Para os trotskistas da década de 30, Kronstadt levanta as mesmas dúvidas sobre os rumos da Revolução que os julgamentos de Moscou e o Pacto de não-agressão levantam para os stalinistas. O episódio trouxe dúvidas a muitos escritores americanos de esquerda da época, como explica Diggins:

Shortly after the countertrial cleared Trotsky of the charges, he became the object of a different one, first raised by Dwight Macdonald. As leader of the Red Army, Trotsky had presided over the Suppression of anarchist sailors in the Kronstadt uprising of 1921. Had Trotsky succeeded Lenin, would the Course of Russian history have been different? Once the whisper of Kronstadt was

${ }^{152}$ Os sinais da divisão que começa a surgir na Esquerda americana a partir dessa guerra podem ser vistos no discutido rompimento da amizade de Ernest Hemingway e John Dos Passos, que, segundo a versão mais divulgada, teria ocorrido por causa do assassinato de José Robles, amigo de Dos Passos, supostamente morto por comunistas sob a suspeita de ser um espião fascista. $\mathrm{O}$ episódio não só separou - segundo a versão mais conhecida dos fatos - os dois amigos escritores como também dividiu a esquerda sobre a participação do PC no conflito na Espanha. Esse episódio é contado com detalhes no livro Ponto de Ruptura - Hemingway, John dos Passos e o Assassinato de José Robles (KOCH, Stephen. São Paulo: Difel, 2008).

153 "But throughout most of the thirties Trotsky stood in the American Left's imagination as 'a fearful monument,' whose ideas of permanent revolutionary struggle burned brighter with each defeat of the working class. (...) In some respects Trotsky was to the anti-Stalinist Old Left of the thirties what Lenin had been to the Lyrical Left of the First World War years. Eastman, Reed, and other Greenwich Village radicals saw in Lenin the glorious identity of history and will; he was the revolutionist whose daring conquest of power in 1917 seemed to symbolize the fulfillment of both the idea and the deed of Marxism. Trotsky enjoyed a similar heroic image, but for the generation of the thirties it took on a different character - the purity of an idea whose essence had been tainted by Stalin. He emerged as the "prophet outcast" who in losing power had saved the conscience of the revolution." (DIGGINS, op. cit., p. 183). 
circulated, many American writers expressed doubts that Trotsky himself would have shrunk from establishing a ruthless dictatorship ${ }^{154}$.

Remetendo-nos a esse questionamento - apoiado nos eventos de Kronstadt - sobre os rumos que a revolução tomaria sob a liderança de Trotsky, Daniel anuncia sua descrença na ideia de revolução. Se uma ação de comando do maior crítico de Stalin se aproxima tanto do típico tratamento de choque stalinista contra a dissidência, o que sobra de esperança revolucionária? É esse o sentimento de parte da esquerda nos anos 60 figurado na desconfiança de Daniel. A noção reformista de "democracia participativa" elaborada pela SDS é filha dessa desconfiança nas grandes rupturas que as revoluções promovem. Sintomática da desorientação a que o narrador dá forma é a rejeição de Daniel, que veremos adiante, também ao reformismo da SDS.

Daniel conclui essa sequência de fatos da Revolução Russa que impactaram a consciência da esquerda mundial com o seu Termidor. Sintomaticamente, dentro da fortuna crítica do romance, não encontrei tentativas de interpretação do lugar da História soviética nesse livro que trata, explicitamente, da história da esquerda.

Esse silêncio da crítica sobre um tema obviamente importante na constituição do panorama político da esquerda que Daniel tenta montar sinaliza uma dificuldade de compreensão que o próprio romance enfrenta - mais franca e ousadamente, diga-se - e tenta tematizar. Em outra passagem em que Daniel trata dos Julgamentos de Moscou - e, em especial, do caso Bukharin -, ele se pergunta quais seriam os motivos da satisfação americana em relação aos "fatos do tormento nacional russo" e aventura uma hipótese que relaciona esse sentimento dos americanos ao tratamento que sua irmã recebeu após a tentativa de suicídio:

Dentro de um ano, noventa e oito membros do Comitê Central foram presos e fuzilados. (Ficamos sabendo disso graças a $\mathrm{N}$. Krutchev, no seu discurso pronunciado no XX Congresso do Partido). As acusações foram renovadas e Bukharin foi julgado.

${ }^{154}$ DIGGINS, op. cit., p. 182. 
$\mathrm{Na}$ verdade existem mistérios independentes a serem aqui examinados. Por que motivo os fatos do tormento nacional russo fazem com que os americanos se sintam satisfeitos? Por que dois policiais, ao encontrarem uma jovem esvaindo-se em sangue no lavatório da Howard Johnson's, não a conduziram ao hospital mais próximo, e sim ao manicômio público mais próximo? Pensando bem, esses dois mistérios talvez se relacionem um com o outro ${ }^{155}$. (pp. 24-25)

Nesse livro cheio de enigmas, essa relação sugerida por Daniel pede para ser decifrada ao mesmo tempo que impõe dificuldades à tarefa. A tentativa de suicídio de Susan é explicada no romance como resultado do passado traumático de dissidência da família Isaacson (esse é o diagnóstico do doutor Duberstein, lembremos) e como uma "falha de análise" (segundo Daniel). Susan tenta criar contatos entre a militância de seus pais e a sua. No livro de medicina imaginado por Daniel, ela figura como a última ponta da linha vermelha que liga três gerações da família Isaacson pela "loucura". Sua morte representa o fim dessa sucessão e, na alegoria política do romance, o fim de um tipo de engajamento e de um sonho de mudanças. A loucura de Susan representa a falência de um certo projeto de mundo que ela teria herdado de sua mãe. Assim, a insanidade de Susan e o desmoronamento do sonho socialista se relacionam.

A menção ao famoso discurso de Krutchev vem, no trecho acima, entre parênteses e separada por ponto final dos períodos anterior e posterior. Assim, duplamente isolada (por parênteses e pontos) do resto do parágrafo, essa inserção cria um espaço de intervenção do narrador no discurso acadêmico sobre a História da Revolução Russa escrito pelo pesquisador Daniel. Intervenção semelhante foi observada em trecho acima discutido. Significativamente, nas duas ocasiões a intromissão do narrador se dá em meio à exposição - em texto que se pretende acadêmico - sobre os Julgamentos de Moscou e o caso Bukharin.

No seu ensaio sobre os sinais de pontuação, Theodor Adorno compara o uso das inserções parentéticas ao do travessão, concluindo que, enquanto este "na medida em que

\footnotetext{
${ }^{155}$ No original: Within a year, ninety-eight members of the Central Commitees were arrested and shot. (We learn this from N. Khrushchev in his address to the $20^{\text {th }}$ Party Congress). Then the charges were reinstated and Bukharin was put on trial. Why the facts of Russian national torment make Americans feel smug? Why do two state cops, finding a young girl bleeding to death in the ladies' room of a Howard Johnson's, take her not to the nearest hospital, but to the nearest public insane asylum? On second thought these mysteries may not be unrelated. (pp. 15-16).
} 
retira do fluxo da frase a inserção, sem a encarcerar, captura tanto a relação quanto a distância", os parênteses isolam o material da frase, criando "enclaves ${ }^{156}$ ". Os enclaves que os parênteses criam nos dois trechos mencionados são de ordem temporal e ideológica. Eles explicitam a distância entre a visão de Daniel (e, por extensão alegórica, dos anos 60) e a visão da geração de seus pais sobre episódios como os Julgamentos de Moscou e o Pacto de não-agressão. Daniel - tendo acesso às informações sobre o regime de Stalin divulgadas a partir de 1956 e vivendo em um contexto ideológico menos propício à contestação do capitalismo do que os anos 30 -, pode, por esse motivo, olhar com desconfiança para certos dados da História da Revolução Russa. Tal acesso não existia para a geração dos seus pais. Mais do que isso: o distanciamento é também ideológico, uma vez que, pode-se supor, o conhecimento do Terror Stalinista não abalaria a convicção da geração de 30 sobre o comunismo. Em entrevista a Simon Schama ${ }^{157}$, Eric Hobsbawm relata ter sido muitas vezes confrontado com a capciosa pergunta: "você é comunista apesar de tudo o que se sabe hoje sobre o regime de Stalin?". Para Hobsbawm, essa é uma questão típica dos anos de polarização aguda entre as democracias capitalistas ocidentais e o bloco soviético. Nesse contexto, as notícias negativas sobre o regime soviético eram integradas ao arsenal ideológico das potenciais capitalistas e usadas contra os comunistas. O acerto de contas de Daniel com a História da Revolução Russa e com a interpretação que diferentes contextos ideológicos fizeram dessa história (os dois movimentos ocorrem simultaneamente nas passagens aqui analisadas) é feito sob a influência do mesmo clima antissoviético que gera a pergunta com que Hobsbawm e outros militantes de esquerda são confrontados a partir da Guerra Fria.

A criação desses enclaves expressa formalmente o distanciamento ideológico entre as gerações de Daniel (60s) e a de seus pais (30s). Ao mesmo tempo, sua inserção em trechos vazados em discurso que se pretende acadêmico e imparcial e que versa sobre alguns dos temas mais importantes para a Esquerda dos anos 30 demonstra a encruzilhada ideológica desse narrador que tenta escrever uma história de continuidades a partir de um momento de ruptura (anos 60). Em importante obra publicada em $1971^{158}$ - mesmo ano

\footnotetext{
${ }^{156}$ ADORNO, Theodor. Notas de Literatura I. São Paulo: Duas Cidades; Ed. 34, 2003, p. 147.

157 (Hobsbawm: A life in history. BBC Radio 4. Saturday 14 April, 2012. http://www.bbc.co.uk/programmes/b01g4f87).

${ }^{158}$ Para Sean Homer e Douglas Kellner, Marxismo e Forma (1971) "introduced a tradition of dialectical Marxist literary theory to the English-speaking world." (HOMER, Sean, KELLNER,
} 
da publicação de The Book of Daniel - Fredric Jameson comenta a distância entre a “atmosfera dos anos 30" e o clima político no final dos anos 60:

The burning issues of those days - anti-Nazism, the Popular Front, the relationship between literature and the labor movement, the struggle between Stalin and Trotsky, between Marxism and anarchism - generated polemics which we may think back on with nostalgia but which no longer correspond to the conditions of the world today ${ }^{159}$.

A consciência dessa distância e o desejo de buscar pontos de continuidade entre as gerações - ambos fermento para a ambivalência do narrador - aparecem no episódio da Marcha ao Pentágono, no qual Daniel se junta a essa grande manifestação contra a Guerra do Vietnam em busca de algum tipo de comunhão com os problemas de sua época e com as formas de protesto e de posicionamento político de sua geração. Em um dos confrontos entre manifestantes e as forças repressivas mobilizadas para assegurar esse símbolo máximo da mentalidade belicista americana que é o Pentágono ${ }^{160}$, Daniel é agredido por agentes do governo. A experiência da dor física como manifestação sensível da repressão faz Daniel se lembrar das lutas que gerações anteriores enfrentaram e da violência com que foram reprimidas. Filho de um casal de radicais de esquerda executado num contexto de grande repressão política - o Macarthismo - Daniel, em diálogo com sua esposa, comenta a diferença que vê entre a reação contra o radicalismo político em sua época e no tempo de seus pais: “- Escute - disse, procurando não assobiar entre dentes. - Parece pior do que é na verdade. Isso não é nada. Hoje em dia é muito mais fácil ser revolucionário do que antigamente ${ }^{161 \%}$. (p. 270)

Douglas. Fredric Jameson: a critical reader. New York: Palgrave Macmillan, 2004, Introdução, xiii).

159 JAMESON, Fredric. Marxism and Form - twentieth-century dialectical theories of literature. Princeton: Princeton University Press, 1971, Preface, IX.

${ }^{160}$ Sobre esses confrontos e seu significado simbólico, conferir MAILER, Norman. The Armies of the Night-History as a Novel, The Novel as History. New York: Penguin, 1994.

${ }^{161}$ No original: "Listen," I said, trying not to whistle through my teeth. "It looks worse than it is. There was nothing to it. It is a lot easier to be a revolutionary nowadays than it used to be." (p. 257). 
A comparação entre a Marcha ao Pentágono e o episódio de Peekskill - do qual Daniel guarda dolorosa memória ${ }^{162}$ - reforça a sensação de distância entre os dois contextos de ação revolucionária apontada pelo narrador na manifestação contra a Guerra do Vietnam. As batalhas que seus pais travaram nas décadas de 30, 40 e 50 eram mais ameaçadoras e exigiam um comprometimento revolucionário maior. As posições e os antagonismos eram mais claros e as grandes questões mobilizadoras - como a Guerra Civil Espanhola - suscitavam convergência de forças, ao contrário da dispersão de energia que as micropolíticas dos anos 60 criam.

Os anos 30, período de formação política dos pais de Daniel, fornecem o contraponto que o narrador parece querer evocar na cena de violência acima comentada. A leitura do texto a seguir pode fornecer o pano de fundo histórico a que a evocação de Daniel parece nos remeter:

The reality with which the Marxist criticism of the 1930s had to deal was that of a simpler Europe and America, which no longer exist. Such a world had more in common with the life forms of earlier centuries than it does with our own. To say that it was simpler is by no means to claim that it was easier as well: on the contrary! It was a world in which social conflict was sharpened and more clearly visible, a world which projected a tangible model of the antagonism of the various classes towards each other, both within the individual nation-states and on the international scene as well - a model as stark as the Popular Front or the Spanish Civil War, where people were called on to take sides and to die, which are, after all, always the most difficult things ${ }^{163}$.

A frase de Daniel sobre a maior facilidade da ação revolucionária em seu tempo pode indicar que, para o narrador, a natureza do engajamento nos anos 60 - com sua pluralidade de alvos e de estratégias ${ }^{164}$ - requer um compromisso menos inequívoco e

\footnotetext{
${ }^{162} \mathrm{O}$ episódio como lembrado por Daniel: Estou apavorado. A lembrança de minha avó sugeriu um novo sentido para as suas famosas pragas - não são o delírio de uma velha louca e sim a exata e poderosa introjeção de medidas de desgraça nas nossas vidas. O ônibus oscilava. Vamos todos morrer. Meu coração pulsa furiosamente... (p. 60) No original: I am in an intoxication of fear. The thought of my grandma has suggested a new meaning of her famous curses - not as the rantings of an old madwoman, but the exact and potent introjections of measures of doom into our lives. The bus is rocking. We are all going to die. My heart beats furiously... (p. 50).

${ }^{163}$ JAMESON, op. cit., Preface, XVII.

${ }^{164}$ Mais adiante, veremos como Norman Mailer descreve a Marcha ao Pentágono como uma batalha simbólica.
} 
definitivo que aquele com o qual seus pais se comprometeram nos anos 30, com consequências e desdobramentos nos anos 40 (Peekskill, por exemplo) e 50 (julgamento e execução).

Um contraste ilustrativo com o contexto de esvaziamento da política que começa a se delinear no final dos anos 60 - e cuja “estrutura de sentimento" é perceptível em The Book of Daniel - pode ser estabelecido observando-se a seguinte fala de Robert Jordan, voluntário na Guerra Civil Espanhola protagonista de For Whom the Bell Tolls, que comenta seu engajamento na causa antifascista:

It gave you a part in something that you could believe in wholly and completely and in which you felt an absolute brotherhood with the others who were engaged in it. It was something that you had never known before but that you had experienced now and you gave such importance to it and the reasons for it that your own death seemed of complete unimportance; only a thing to be avoided because it would interfere with the performance of your duty. But the best thing was that there was something you could do about this feeling and this necessity too. You could fight ${ }^{165}$. (p. 210)

Ressalvadas as especificidades de cada contexto, o contraste entre o engajamento de Robert Jordan e o sentimento de não pertencimento de Daniel - manifesto no episódio dos Cartões de Convocação - ilustra a distância entre o ambiente político de Daniel e o das gerações anteriores, distância a partir da qual se constrói o mosaico de rupturas e continuidades que é esse romance. A disposição de morrer em uma luta de outro país que leva o personagem de Hemingway - e vários voluntários americanos da época ${ }^{166}$ - à

${ }^{165}$ HEMINGWAY, Ernest. For Whom the Bell Tolls. St. Albans: Triad/Panther Books, 1976. Em português: Integração da criatura em algo em que podia acreditar inteiramente, completamente, e onde existia um profundo sentimento de fraternidade por todos os que participavam do mesmo credo. Era algo jamais sentido antes e que, experimentado agora, adquiria uma importância suprema diante da qual a morte nada significava; a morte passava a ser evitada apenas porque poderia interferir no cumprimento do dever. Mas o melhor era o poder obedecer-se a este sentimento e a esta necessidade. Podia-se lutar. (Por quem os sinos dobram. São Paulo: Companhia Editora Nacional, 1969. Tradução de Monteiro Lobato, p. 228).

${ }^{166}$ Como os voluntários da revolucionária Brigada Abraham Lincoln: "The Abraham Lincoln Brigade, in which around 90 African Americans fought, was the first non-segregated American military unit ever to exist - the United States Army itself continuing to operate segregation throughout the Second World War. Viewed through this optic, what the International Brigades symbolize is a certain spirit of future possibility. They were - though very imperfectly and by no means consciously - the soldiers of cosmopolitan cultural modernity." (GRAHAM, Helen. The Spanish Civil War: A Very Short Introduction. New York:Oxford University Press, 2005, pp.4445). 
Espanha pode parecer incompreensível num universo político cada vez mais pautado por lutas locais. Para os habitantes desse nosso mundo - cujo berço é os anos 60 - Eric Hobsbawm explica o tipo de compromisso que mobilizava os voluntários da Guerra Civil Espanhola:

For the benefit of readers who have grown up in the moral milieu of the late twentieth century, it must be added that these were neither mercenaries, nor, except in a very few cases, adventurers. They went to fight for a cause ${ }^{167}$.

A consciência da forma ${ }^{168}$ desse romance se manifesta na "Nota ao Leitor" que aparece imediatamente após a longa passagem em que Daniel comenta fatos da História da Revolução Russa. Retomemos o final dessa passagem, o "Termidor” acima discutido, a fim de situar essa "Nota" no romance:

Termidor.

Daniel Termidor encontrou considerável falha na direção do Volvo e que dizer de Kronstadt? Não devemos esquecer KRONSTADT! E também Gorky, com suas ideias incômodas.

\section{Nota ao Leitor}

Leitor, esta nota se destina a você. Se lhe parecer elementar, se, depois de tudo isto lhe parecer elementar... Se for realmente elementar e lhe parecer, a essa altura, pateticamente elementar,

${ }^{167}$ HOBSBAWM, Eric. The Age of Extremes - A History of the World, 1914-1991. New York: Vintage Books, 1996, p. 160.

168 O que chamo aqui de "consciência da forma" no romance é a capacidade de incorporar à própria obra os dilemas e as dificuldades de se pensar as questões ali enfrentadas, em vez de simplesmente escondê-las sob conciliatórias resoluções simbólicas. Essa noção é próxima do conceito de "metacomentário", que Fredric Jameson criou para descrever o processo de interpretação o qual se debruça sobre o próprio ato de interpretar e investiga seus pressupostos, reações e tendências numa tentativa de situar-se historicamente. Esse "procedimento mental" é explicado pelo autor: "In matters of art, and particularly of artistic perception, in other words, it is wrong to want to decide, to want to resolve a difficulty: what is wanted is a kind of mental procedure which suddenly shifts gears, which throws everything in an inextricable tangle one floor higher, and turns the very problem itself (the obscurity of this sentence) into its own solution (the varieties of Obscurity) by widening its frame in such a way that it now takes in its own mental processes as well as the object of those processes. In the earlier, naive state, we struggle with the object in question: in this heightened and self-conscious one, we observe our own struggles and patiently set about characterizing them". (JAMESON, Fredric. PMLA, Vol. 86, No. 1 (Jan., 1971), pp. 9-18. Modern Language Association, p. 9. http://www.jstor.org/stable/460996 (acesso em 27/09/2013). 
como recolher farrapos de roupas rasgadas para tornar a rasgá-las... Se for a este ponto elementar, então, leitor, eu o compreendo muito bem [I am reading you, no original]. E juntos rasgaremos nossas roupas, entre lamentações ${ }^{169}$. (pp. 64-65)

O narrador, nesse trecho, coloca em suspensão a expectativa do leitor, reforçada pelo trecho imediatamente anterior à "Nota", de que o livro de Daniel seja uma longa crítica às ideias e estratégias de ação das gerações de radicais anteriores aos anos 60. A ambivalência do narrador e o mosaico narrativo construído por ele são testemunhos da complexidade do material social que o livro confronta. A longa passagem sobre a História da Revolução Russa que se encerra nessa "Nota ao Leitor" começa, como foi mostrado, com uma comparação (sugerida pela justaposição dos parágrafos) entre o sacrifício revolucionário de Paul e de Bukharin - o que estabelece um vínculo problemático entre o contexto ideológico dos anos 30 nos Estados Unidos e o Terror do regime de Stalin; passa por momentos de questionamento da herança soviética - como nos trechos entre parênteses que analisamos acima - e termina no "Termidor de Daniel". A "Nota ao Leitor" que encerra essa condensada incursão pelo terreno minado das posições de esquerda sobre os caminhos da Revolução Russa expressa uma consciência de que o livro não pode entregar respostas "elementares". A "Nota" monta uma armadilha narrativoideológica que lembra aquela montada por Machado em Dom Casmurro ${ }^{170}$ : o leitor que entender a história contada por Daniel de forma "elementar" será ele mesmo presa de um tipo de leitura da história que a narração procura denunciar como insuficiente e será parte do enigma que Daniel tenta desvendar: "If it is that elementary, then reader, I am reading you".

Assim como o leitor que adere facilmente à argumentação do patriarcal Bentinho (apesar de todas as pistas de que se trata de relato não-confiável) denuncia, nessa adesão imediata, sua aceitação dos valores que sustentam a situação de classe desse narrador, o

\footnotetext{
${ }^{169}$ No original: Thermidor. / Daniel Thermidor found considerable play in the Volvo's steering. and what about Kronstadt - we mustn't forget KRONSTADT! And Gorky, too, with his untimely thoughts. / A NOTE TO THE READER / Reader, this is a note to you. If it seems to you elementary, if it seems after all this time elementary... If it is elementary and seems to you at this late date to be pathetically elementary, like picking up some torn bits of cloth and tearing them again...If it is that elementary, then reader, I am reading you. And together we may rend our clothes in mourning. (pp. 53-54).

${ }^{170}$ Ressalva feita à distância dos contextos histórico e ideológico entre os dois romances.
} 
leitor que vê a narração de Daniel como uma elementar rejeição das ideias políticas da geração de Paul e Rochelle demonstrará sua concordância fácil a essa rejeição e será, portanto, matéria para a investigação de Daniel sobre os motivos desse abandono de ideias políticas que marca a passagem de uma geração da esquerda americana para outra.

Essa "Nota" pode ser lida como a emersão na superfície da forma de um impulso ideológico de simplificação e de rejeição de um raciocínio totalizante que busca conectar elementos diversos da vida social (como a tentativa de suicídio de Susan e a satisfação dos americanos com os "fatos do tormento nacional russo") numa teia de relações complexa. Essa força imobilizadora do pensamento é, em última instância, o maior inimigo de Daniel. Trechos como a seção intitulada "The True History of the Cold War" mostram a disposição do narrador de buscar uma versão mais dialética dos fatos históricos e de se "imiscuir nos mecanismos profundos e complicados do universo" (p.81). Em trechos como essa "Nota ao Leitor" percebemos a presença dos parâmetros conceituais que moldam o pensamento hegemônico e impedem articulações mais totalizantes. A pressão que tal pensamento exerce contra o trabalho dialético, particularmente nos Estados Unidos, é reconhecida, em Marxismo e Forma, como "adversário conceitual" inevitável de qualquer leitura dialética:

Less obvious, perhaps, is the degree to which anyone presenting German and French dialectical literature is forced - either implicitly or explicitly - to take yet a third national tradition into account, I mean our own: that mixture of political liberalism, empiricism, and logical positivism which we know as AngloAmerican philosophy and which is hostile at all points to the type of thinking outlined here. One cannot write for a reader formed in this tradition - one cannot even come to terms with one's own historical formation - without taking this influential conceptual opponent into account. (...) the anti-speculative bias of that tradition, its emphasis on the individual fact or item at the expense of the network of relationships in which that item may be embedded, continue to encourage submission to what is by preventing its followers from making connections, and in particular from drawing the otherwise unavoidable conclusions on the political level ${ }^{171}$.

${ }^{171}$ JAMESON, Fredric. Marxism and Form - twentieth-century dialectical theories of literature. Princeton: Princeton University Press, 1971, Preface, X. 
O teor dialético da "Nota ao Leitor" de Daniel se encontra no imbricamento dos caminhos conceituais mapeados por Jameson em Marxismo e Forma.

\section{Um narrador consciente: Daniel confronta o leitor}

O "influente adversário conceitual” que Jameson percebe como força contrária ao estabelecimento de conexões que levem a "inevitáveis conclusões no nível político" ganha expressão no romance em momentos de consciência da forma como a "Nota ao Leitor" e o trecho a seguir, que reproduzo no original por apresentar sutilizas de linguagem de difícil tradução:

Oh, baby, you know it now. We done played enough games for you, ain't we. You a smart lil fucker. You know where it's at now, don' you big daddy. You got the picture. This the story of a fucking, right? You pullin' out yo lit-er-ary map, mutha? You know where we goin', right muthafuck? ${ }^{172}$ ( pp. 22-3)

Esse parágrafo metaficional é antecedido pela narrativa em terceira pessoa do episódio em que Daniel e Susan são levados pelo advogado Ascher a um ato público em protesto contra a iminente execução de Paul e Rochelle. Ao chegar ao local do protesto, as crianças são carregadas pela multidão até o palco. A forte impressão que esse espetáculo deixa na memória do menino Daniel pode ser percebida no tom em que o episódio é narrado:

E o rugir da multidão tornou-se um canto, um grande coro, que despertava ecos nos prédios, até tornar-se contínuo: Liberdade para eles, liberdade para eles, liberdade para eles! E Daniel e Susan, transfixados pelos cartazes, os imensos retratos do pai e da mãe espalhados por toda parte, acima da multidão, subindo e descendo

\footnotetext{
${ }^{172}$ Em português: Meu bem, agora você sabe. Já jogamos muitas vezes, não jogamos? Você é uma malandrinha esperta. Você sabe o que quer, não sabe, papaizinho? Você entende. Esta é a história de uma trepada, certo? Vai consultar seu mapa li-te-rá-ri-o, mamãezinha? Sabe para onde vamos, certo, filha da mãe? (p. 21).
} 
ao ritmo dos gritos da multidão: Liberdade para eles, liberdade para eles, liberdade para eles! ${ }^{173}$ (p. 31)

O contraste de linguagem entre os dois trechos é evidente. O tom memorialístico da narrativa em terceira pessoa sobre um episódio traumático da infância de Daniel e Susan é bruscamente interrompido pelo parágrafo em segunda pessoa - dirigido ao leitor, ou ao próprio Daniel - escrito em linguagem vulgar, até ofensiva, em que o narrador, num gesto metaficcional, põe em evidência os parâmetros mentais do leitor (ou dele mesmo, como escritor em processo de criação). O tom dramático da narrativa em terceira pessoa sobre o martírio das crianças Isaacson pode ser plotado no "mapa literário" do leitor (ou do escritor) como prenúncio de um drama que culmina no suicídio de Susan e nos tormentos de Daniel. Assim, treinado (pelo cinema e por parte do romance burguês, por exemplo) a acompanhar narrativas pessoais - dramas subjetivos - o leitor e o escritor são tentados a buscar apoio no modelo narrativo que enfatiza trajetórias individuais ("This the story of a fucking, right?") em vez de dramas coletivos. A agressividade com que Daniel interrompe as memórias de seu drama pessoal, narradas em terceira pessoa, aliada à linguagem ofensiva e ao uso da segunda pessoa, são indícios de um desejo do narrador de recusar uma leitura meramente romanesca do destino da família Isaacson. Efeito semelhante tem a ironia com que Daniel se refere ao drama familiar ocasionado pela tentativa de suicídio de sua irmã ${ }^{174}$.

Se o que antecede o agressivo parágrafo aqui analisado é uma passagem em terceira pessoa escrita em tom memorialístico e cheia de lirismo e drama, o que o sucede é mais um dos pequenos ensaios historiográficos de Daniel, este intitulado "Um Interessante Fenômeno ${ }^{175}$ ", no qual o narrador comenta a histeria da guerra e como ela influenciou na constituição de um ambiente de temor e agressividade favorável ao

\footnotetext{
${ }^{173}$ No original: And the roaring of the crowd had become a chant, a great choir echoing against the buildings until it was continuous: Free them, free them, free them! And he and Susan were transfixed by the placards, the oversized pictures of their mother and father everywhere above the crowd, going up and down in rhythm as the crowd roared Free them, free them, free them. (p. 22).

${ }^{174}$ Episódio analisado acima. Para lembrarmos, o trecho referido é: "He was thankful to Susan for relieving the dangerous tedium of his graduate life. She would be all right. In the meantime there was drama, a sweet fatality, a recharging of the weak diffused impulses of giving a shit." (p. 15).

${ }^{175} \mathrm{O}$ trecho em questão está reproduzido no início do capítulo.
} 
surgimento do fenômeno da Guerra Fria. Ao contrário do tom subjetivo do trecho memorialístico, nessa longa passagem ensaística Daniel lista, em tom objetivo, uma série de fatos históricos que prenunciam a emergência do estado de conflito o qual predominou nos anos da Guerra Fria. Ênfase é dada à relação entre perseguição ideológica, repressão a reivindicações trabalhistas e o "red scare" - o temor de uma revolução socialista nos Estados Unidos. A seguir, listo os fatos históricos mencionados por Daniel nessa passagem:

"In the greater arena of social relations - business, labor, the community - violence rises, fear and recrimination dominate public discussion, passion prevails over reason". (p. 23)

"...the continuance beyond the end of war of the war hysteria". (p. 23)

"Congress failure to ratify Wilson's dream of a League of Nations..." (p. 23)

"On the labor from in 1919 there was an unprecedented number of strikes..." (p. 23)

"In Seattle there was a general strike which precipitated a nationwide "red scare"" (p. 24)

"It was feared that as in Russia, they were about to take over the country and shove large cocks into everyone's mother" (p. 24)

The America Legion, just founded, raided I.W.W headquarters... (p. 24)

"Laws against seditious speech were passed in State Legislatures across the country and thousands of people were jailed... To say nothing of the Espionage Act of 1917, which took care of thousands more. To say nothing of Eugene Debs.” (p. 24)

"Attorney General Palmer ... organized a Federal raid on Communist Party offices ... With his right-hand assistant, J. Edgar Hoover..." (p. 24) 
"The Ku Klux Klan blossomed throughout the South and West" (p. 24)

“Over seventy Negroes were lynched in 1919” (p. 25)

N. Sacco and B. Vanzetti: "The story of this trial is well known and often noted by historian and need not be recounted here." (p. 25)

A justaposição dessas três passagens de conteúdo e tons narrativos distintos representa bem o mosaico criado em The Book of Daniel. Antes de ser um amontoado de fragmentos, essas passagens estão justapostas de maneira a criar significados, como visto na análise dos trechos acima. Entre o trecho testemunhal/subjetivo e o ensaísticohistoriográfico, uma intromissão do narrador afronta o leitor para lembrá-lo de que há mais na história de Daniel do que apenas um drama familiar, como os fatos históricos listados pelo narrador insinuam haver.

Consciente do potencial despolitizante de uma leitura focada no drama familiar do órfão da Guerra Fria, Daniel injeta em seu relato pequenas doses de sadismo cujo efeito é dificultar a identificação e simpatia do leitor para com o narrador e, assim, manter uma saudável margem de desconfiança quanto à construção da narrativa e às intenções de quem a escreve. Tal gesto do narrador, que voluntariamente coloca em suspensão sua autoridade de voz organizadora da experiência narrada, trata também da crise do narrador no romance contemporâneo, descrita por Theodor Adorno ${ }^{176}$. No entanto, o alto grau de consciência da forma desse gesto de autoquestionamento da autoridade do narrador traz um avanço cognitivo para a narração nesse romance.

\footnotetext{
176 "Desintegrou-se a identidade da experiência - a vida articulada e contínua em si mesma - que só a postura do narrador permite. É preciso apenas ter presente a impossibilidade de quem quer que seja, que tenha participado da guerra, a narrasse como antes uma pessoa contava suas aventuras. / Com justiça, a impaciência e o ceticismo vão ao encontro da narração que surge como se o narrador dominasse tal experiência. (...) Narrar algo significa, na verdade, ter algo especial a dizer, e justamente isso é impedido pelo mundo administrado, pela estandartização e pela mesmidade. Antes de qualquer mensagem de conteúdo ideológico já é ideológica a própria pretensão do narrador - como se o curso da vida ainda fosse em essência o da individuação, como se o indivíduo alcançasse o destino com suas emoções e sentimentos, como se o íntimo do indivíduo ainda pudesse alguma coisa sem mediação: a disseminada subliteratura biográfica é um produto de desagregação da própria forma do romance". (ADORNO, Theodor. Posição do narrador no romance contemporâneo. In: BENJAMIN, Walter; HORKHEIMER, Max; ADORNO, Theodor \& HABERMAS, Jürgen. Textos escolhidos. São Paulo: Abril Cultural, 1983, pp. 269-270).
} 
Esse efeito de afastamento e antipatia propositalmente criado pelo narrador já se insinua nas primeiras páginas do romance, quando Daniel é apresentado ao leitor, em terceira pessoa, em momento de fragilidade: em visita à irmã no hospital psiquiátrico. Qualquer simpatia que o leitor estabeleça por Daniel nessas primeiras páginas, logo começará a se desfazer quando encontramos o narrador tratando sua mulher com crueldade em ato sexual descrito com detalhes sádicos. É o próprio Daniel que comenta o efeito que tal cena pode ter na adesão do leitor ao seu relato:

E se é esta a primeira impressão que as pessoas captam de mim, como conseguirei criar simpatia? Se quiser revelar uma crise desabando num momento pouco favorável para mim, por que não começar com as prateleiras de livros - Daniel percorrendo as prateleiras, em busca, demasiado tarde, de uma tese? ${ }^{177}$ (p. 15)

As cenas de crueldade de Daniel contra sua mulher se repetem ao longo da narrativa. Em uma delas, Daniel, durante passeio em família num parque, começa de brincadeira a arremessar o filho - Paul - para cima e vai arremessando o bebê a alturas cada vez maiores, levando sua mulher do desconforto ao pânico e colocando a segurança do próprio filho em risco. $\mathrm{O}$ ato atrai olhares de desconfiança e reprovação de pessoas que observam a cena.

Em outro ponto do enredo, acompanhamos Daniel acelerar perigosamente o velho carro de Susan, cujos freios necessitam de reparos, enquanto obriga sua esposa Phyllis a tirar as calças e a se ajoelhar no banco do passageiro. Phyllis implora para Daniel desacelerar o carro e religar os limpadores de para-brisa, que ele desligara com o fim de adicionar dramaticidade à situação. Mesmo diante dos apelos de Phyllis pela segurança do filho do casal, que dormia no banco de trás, Daniel não recua de sua demanda. Logo Phyllis sucumbe, resignada com os constantes maus-tratos do marido. Daniel pressiona o acendedor de cigarros aceso no corpo de sua mulher. A cena é narrada assim:

A chuva tamborilava com força. O trovão rugia, feroz. Carros passavam à esquerda. $\mathrm{O}$ firmamento estava negro. Daniel inclinouse para a frente e comprimiu o acendedor de cigarro. A mão permaneceu imóvel. Vocês acreditam? Devo continuar? Querem saber o efeito de três círculos concêntricos de elemento ardente, de brilho alaranjado, numa escura noite de chuva, sobre a suave e

\footnotetext{
${ }^{177}$ No original: And if the first glimpse people have of me is this, how do I establish sympathy? If I want to show disaster striking at a moment that brings least credit to me, why not begin with the stacks, Daniel roaming through the stacks, searching, too late, for a thesis. (p. 7).
} 
branca epiderme do traseiro de minha mulher? Quem é você, afinal? Quem lhe disse que podia ler isto? Não existe nada sagrado ${ }^{178}$ (pp. 70-71)

Daniel evoca a curiosidade cúmplice do leitor ao mesmo tempo que questiona a bisbilhotice de quem acompanha essa narração de coisas difíceis, e mesmo inexplicáveis. É como se o narrador estivesse - nesse e em outros momentos em que aparece a segunda pessoa $^{179}$ - alertando quem acompanha a sua narração de que não há saída fácil nem explicação segura para a vida que Daniel entrega ao leitor como testemunho de tempos conturbados.

Os momentos de sadismo de Daniel contra sua esposa não aparentam ter explicação identificável na sua constituição psíquica ou na lógica narrativa do romance. Aqui, pode-se traçar um paralelo, sugerido no próprio romance ${ }^{180}$, entre o narrador Daniel e os narradores de Edgar Allan Poe ${ }^{181}$. Essa autossabotagem de Daniel aponta, também,

${ }^{178}$ No original: The rain drummed down. The thunder was fierce. Cars were passing on the left. The sky was black. Daniel leaned forward and pressed the cigarette lighter. His hand remained poised. Do you believe it? Shall I continue? Do you want to know the effect of three concentric circles of heating element glowing orange in the black night of rain upon the tender white girlflesh of my wife's ass? Who are you anyway? Who told you you could read this? Is nothing sacred? (p. $60)$.

${ }^{179}$ Ver, sobretudo, os trechos "Nota ao Leitor", acima analisado, e "O que há de mais monstruoso é a sequência", que será visto adiante.

${ }^{180}$ É o próprio Daniel que sugere tal aproximação ao eleger Poe "O Subversivo Mor": Examples abound. But historians of early America fail to mention the archetype traitor, the master subversive Poe, who wore a hole into the parchment and let the darkness pour through. (...) ... like the poisonous effulgence of combustion engines over Thrift and Virtue and Reason and Natural Law and the Rights of Man. It's Poe, not those other guys. He and he alone. It's Poe who ruined us, that scream from the smiling face of America. (p. 177).

${ }^{181}$ Não levarei essa comparação adiante por ela fugir da direção aqui pretendida. Para o argumento que aqui desenvolvo, basta a caracterização do narrador como não-confiável. Sobre a construção dos narradores em Poe, recomendo a leitura do ensaio The Question of Poe's Narrators, de onde extraí a passagem a seguir, que resume a parte do argumento a qual nos interessa para mostrar a aproximação entre o narrador em The Book of Daniel e os narradores de Poe: "Indeed, he often designs his tales as to show his narrators' limited comprehension of their own problems and states of mind; the structure of many of Poe's stories clearly reveals an ironical and comprehensive intelligence critically and artistically ordering events so as to establish a vision of life and character which the narrator's very inadequacies help to "prove". (...) The structure of Poe's stories compels realization that they are more than the effusions of their narrators' often disordered mentalities. Through the irony of his characters' self-betrayal and through the development and arrangement of his dramatic actions, Poe suggests to his readers ideas never entertained by the narrators. Poe intends his readers to keep their powers of analysis and judgment ever alert; he does not require or desire complete surrender to the experience of the sensations being felt by his characters. The point of Poe's technique, then, is not to enable us to lose ourselves 
para a consciência da forma que recusa a criação de um elo de empatia entre leitor e narrador - o que poderia levar a uma adesão pouco crítica ao relato de Daniel - e mantém a ambivalência da narração, a qual se mostra, por exemplo, no recorrente motivo do "coração", que desenvolverei brevemente a seguir.

\section{What is the matter with my heart?: a confusão de sentimentos políticos e familiares de Daniel.}

O motivo do "coração" é anunciado no último tópico da lista intitulada "Pontos a levar em conta" (p. 25), na qual Daniel esboça uma espécie de plano de pesquisa e reflexão. No item 7 - último da lista - temos:

7. A fundação Isaacson. SERÁ TÃO TERRÍVEL ASSIM NÃO GUARDAR A COISA NO CORAÇÃO, TIRÁ-LA DO CORAÇÃO, ESVAZIAR O CORAÇÃO? QUE É QUE HÁ COM MEU CORAÇÃO?

O verão de 1967 está em princípio. Haveria mais tarde uma onda de cartões de convocação queimados. Haveria tumultos em Newark e Detroit. Nos Estados Unidos, os jovens tentariam uma forma de protesto que se originou neste século entre os monges budistas do Vietnã do Sul. Embebendo-se em gasolina, riscavam fósforos, morrendo queimados como forma de protesto. Mas eu, Daniel, sofria, e as minhas visões me perturbavam. E não quero guardar o assunto no coração ${ }^{182}$. (p. 26)

in strange or outrageous emotions, but to see these emotions and those obsessed by them from a rich and thoughtful perspective". (GARGANO, James. The Question of Poe's Narrators. College English, Vol. 25, No. 3 (Dec., 1963), National Council of Teachers of English. p. 178. http://www.jstor.org/stable/373684 (Acessado em 29/09/2013). O que deve ficar claro nesse comparação é que o narrador de Doctorow possui uma complexidade e uma sofisticação afins aos narradores de Poe.

${ }^{182}$ No original: 7. The Isaacson Foundation. IS IT SO TERRIBLE NOT TO KEEP THE MATTER IN MY HEART, TO GET THE MATTER OUT OF MY HEART, TO EMPTY MY HEART OF THIS MATTER? WHAT IS THE MATTER WITH MY HEART? / The summer of 1967 was just beginning. There would be a wave of draft-card burning. There would be riots in Newark and Detroit. Young people in the United States would try a form of protest originated in this century by the Buddhist monks in South Vietnam. They would douse themselves with gasoline 
A confusão de sentimentos do narrador em relação ao legado político de sua família - presente na menção ao projeto de Susan de criar a Fundação Isaacson para Revolução ${ }^{183}$ - é visível na gradação dos verbos (Não guardar...Tirar...Esvaziar ${ }^{184}$ ) que culmina num indefinido autoquestionamento do narrador (“QUE É QUE HÁ COM MEU CORAÇÃO”), central para a narrativa, que será uma tentativa de encontrar uma resposta para tal questão. $\mathrm{O}$ uso das letras maiúsculas confere maior dramaticidade ao autoquestionamento do narrador, além de confirmar a centralidade dessas questões para o livro que será escrito, uma vez que esse é o único trecho destacado em caixa alta de toda a lista de tópicos a serem levados em conta por Daniel.

O parágrafo seguinte nos remete ao presente histórico do narrador - marcado por intensos conflitos, atos de rebeldia e demonstrações de engajamento (...ondas de cartões de convocação queimados ... tumultos ... jovens ateando fogo a si mesmos) -, em meio ao qual ele vive seu drama (que, alegoricamente, como venho mostrando, traduz os conflitos de sua geração) e expressa seu desejo de se livrar da carga de convicções políticas, lembranças, culpas e responsabilidades sintetizadas no motivo do coração: " $\mathrm{E}$ não quero guardar o assunto no coração".

A exploração simbólica desse motivo com conotação política reaparecerá na legenda da foto das três mulheres Isaacson ${ }^{185}$ (a Avó de Daniel, sua irmã e sua mãe) em cuja legenda se lê: “A linha vermelha indica o avanço da loucura herdado através do coração ${ }^{186 " ~(p . ~ 83) . ~ O ~ c o n t e u ́ d o ~ p o l i ́ t i c o ~ d e s s a ~ " l i n h a ~ v e r m e l h a " ~ r e t o m a ~ o ~ m o t i v o ~ d o ~}$ coração e seu caráter político no romance, como também acontece no ritual de "eat your heart out ${ }^{187 ”}$ (p. 39) a que Paul se submetia ao torturar-se ouvindo comentaristas

and light matches to themselves. They would burn to death in protest. But I, Daniel, was grieved, and the visions of my head troubled me and I do not want to keep the matter in my heart. (p. 17).

${ }^{183}$ No original: The Paul and Rochelle Isaacson Foundation for Revolution. (p. 79).

${ }^{184}$ Em inglês: Not to keep...Get [it] out...Empty.

${ }^{185}$ Analisada no começo desse capítulo.

${ }^{186}$ No original: The red line describes the progress of madness inherited through the heart. (p. $71)$.

${ }^{187}$ No original: "The ritual of eating your heart out". A expressão é de difícil tradução. Uma possibilidade de tradução para o português seria "devorar o próprio coração". O tradutor do romance optou por "ritual da tortura", o que, embora tenha o mérito de enfatizar o significado de 
reacionários no rádio com o objetivo de "manter a tensão revolucionária", na leitura do narrador.

O coração de Daniel conhece um período de paz sob os auspícios de seus pais adotivos - os liberais de classe média Lewins -, em cuja casa os irmãos Isaacson experimentaram uma "ausência de ideologia e de implacável sentimento moral”. (p. 73) Nesse clima pacífico de classe média americana, Daniel e Susan passam por uma

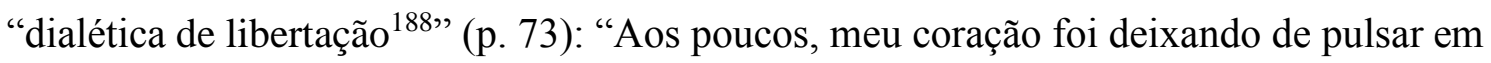
ritmo errático, lembrando o das bolas de borracha que eu costumava fabricar ${ }^{189 "}$. (p. 73)

Aqui, há uma modificação significativa dos dados históricos. Os dois filhos do casal Rosenberg, Robert e Michael, foram adotados por um casal de militantes de esquerda, apesar do esforço de agências governamentais para que os dois fossem adotados e criados por uma família conservadora, a fim de diminuir as chances dessas crianças se tornarem, quando adultas, militantes em favor da revisão do julgamento de seus pais ${ }^{190}$. Essa alteração dos fatos reforça a importância do processo de reeducação política dos irmãos Isaacson na construção dos conflitos ideológicos que irão marcar os dilemas de Susan e Daniel ao longo da narrativa. Tivesse Doctorow, seguindo o dado histórico, posto Susan e Daniel para crescer num ambiente politicamente alinhado às posições de Paul e Rochelle, o conflito do narrador com sua herança política - central para os dilemas do romance -, seria menos verossímil. A modificação que o autor faz do dado histórico sobre o destino dos filhos do casal Rosenberg prova a centralidade, para o romance, do conflito de visões de mundo expresso nos dilemas do narrador Daniel Isaacson Lewin.

autoflagelação do exercício e antecipar o drama que o personagem viverá, elimina o motivo do coração, tão presente e importante ao longo da narrativa.

${ }^{188}$ No original: dialectic of breaking free. (p. 63).

${ }^{189}$ No original: Less and less did my heart bound in erratic dysynchronous jumps, like the rubber band balls I used to make. (p. 63).

190 "The Rosenberg children were adopted by a couple with long-standing ties to the militant left, despite the efforts of various government agencies to place the children with couples whose politics were more congenial to the prevailing Cold War ethos. The less radical Lewins who adopt the Isaacson children are able to transform Daniel and Susan from red diaper babies into mainstream kids of liberal Jewish background." (SCHRANK, Bernice. Getting the Picture: Radical Possibilities in Doctorow's "The Book of Daniel". Studies in American Jewish Literature (1981-), Vol. 12, THE CHANGING MOSAIC: FROM CAHAN TO MALAMUD, ROTH AND OZICK (1993), pp. 62-71. Penn State University. http://www.jstor.org/stable/41206178). (Acessado em 29/09/2013) 
Nas páginas finais do romance, o motivo do coração é retomado com grande clareza de seu conteúdo alegórico. Após listar casos mal sucedidos do então inovador transplante de coração, Daniel fala do problema da rejeição nesse tipo de procedimento cirúrgico e afirma que a medicina ainda deve evoluir muito para que tais insucessos sejam evitados. Esse relato se dá como segue:

A rejeição cardíaca é um problema. O corpo ataca o seu novo órgão como se fosse qualquer objeto estranho. O coração é atacado pelos anticorpos do organismo. É destruído. (...) Os médicos têm ainda muito que aprender a respeito da rejeição. Sim, os médicos têm muito a aprender ${ }^{191}$. (p. 307)

O isolamento temático dessa passagem (ela aparece imediatamente após, separada por espaço, o encontro de Daniel com velho Mindish na Disneylândia ${ }^{192}$ ) no romance aponta para o seu caráter alegórico. Nas páginas finais do livro, - páginas repletas de um sentimento de esgotamento de possibilidades - o motivo do coração reaparece como índice do fracasso de Daniel em estabelecer a conexão que faltava entre o presente e o passado, entre ele, sua irmã e seus pais. Significativamente, um dos três finais do romance será o do enterro de Susan, no jazigo em que seus pais estão enterrados.

Esse fracasso é reforçado pela justaposição dessa passagem sobre rejeição cardíaca com a passagem do encontro entre Daniel e Mindish na Disneylândia, no qual a investigação do narrador entra num beco sem saída.

Lida alegoricamente, a passagem sobre rejeição cardíaca estabelece um paralelo entre o aprendizado necessário à medicina para superar o problema da rejeição do corpo ao transplante de órgãos e o aprendizado político necessário para que lições de lutas passadas se tornem parte da memória política coletiva e ensinem às gerações da Esquerda a reconhecer em seus diferentes enredos elementos da mesma grande narrativa ${ }^{193}$.

${ }^{191}$ No original: Heart rejection is a problem. The body attacks its own new heart as it would any foreigner object. The heart is attacked by the body's antibodies. It is destroyed. (...) Doctors still have a lot to learn about why we reject our hearts. Yes, doctors have a lot to learn. (p. 293).

${ }^{192}$ Para compreender a função simbólica desse encontro no romance, cf. AGILDO, João Rodrigo Lima. A crise da esquerda norte-americana em "The Book of Daniel", de E. L. Doctorow. 2006. 92f. Dissertação (Mestrado emEstudos Linguísticos e Literários em Inglês) - Faculdade de Filosofia, Letras e Ciências Humanas, Universidade de São Paulo, São Paulo, 2006. http://www.teses.usp.br/teses/disponiveis/8/8147/tde-08112007-154057/pt-br.php.

${ }^{193}$ Narrativa cujo sentido e importância para uma compreensão mais ampla do significado histórico de certos objetos estéticos é resumido por Fredric Jameson: "Essas questões, com 
Corações diferentes aceitos e assimilados pelo mesmo corpo é metáfora adequada para a conjunção de ideais políticos de ambientes ideológicos tão diversos quanto os anos 30 e os 60 .

\section{O paralelo entre a história da Esquerda Americana e a investigação familiar de Daniel - $O$ romance histórico e a intersecção de planos ontológicos}

Seguindo a distinção que Paul Ricoeur estabelece em Tempo e Narrativa entre um "plano existencial da vida individual" e um "plano histórico e transindividual", Fredric Jameson propõe que

A arte do romance histórico não consiste na vívida representação de nenhum desses aspectos em um ou em outro plano, mas antes na habilidade e engenhosidade com que a sua interseção é configurada e exprimida; e isso não é uma técnica nem uma forma, mas uma invenção singular, que precisa ser produzida de modo novo e inesperado em cada caso e que no mais das vezes não é passível de ser repetida ${ }^{194}$.

relação a nós, só podem recuperar sua urgência original se forem recontadas dentro da unidade de uma única e grande história coletiva; apenas se, mesmo sob uma forma disfarçada e simbólica, forem vistas como algo que compartilha de um único tema fundamental - para o marxismo, a luta coletiva para se alcançar um reino de liberdade a partir de um reino da necessidade; apenas se forem apreendidas como episódios vitais de uma única trama vasta e incompleta: / "A história de todas as sociedades que já existiram é a história da luta de classes: homem livre contra escravo, patrício contra plebeu, senhor contra servo, mestre da corporação contra artífice assalariado - em suma, opressor contra oprimido - em constante oposição um ao outro, sempre em luta ininterrupta, ora velada, ora declarada, uma luta que sempre terminou ou na reconstituição revolucionária da sociedade em geral ou na ruína comum das classes em oposição." / É quando detectamos os traços dessa narrativa ininterrupta, quando trazemos para a superfície do texto a realidade reprimida e oculta dessa história fundamental, que a doutrina de um inconsciente político encontra sua função e sua necessidade. (JAMESON, Fredric. O Inconsciente Político: A narrativa como ato socialmente simbólico. São Paulo: Ática, 1992, pp. 17-18).

${ }^{194}$ JAMESON, Fredric. O Romance Histórico ainda é possível? Revista Novos Estudos 77, Março 2007, p. 192. 
Com ironia, perspicácia, conhecimentos acadêmicos de história e um apurado senso crítico Daniel mergulha em suas memórias e em seus livros para buscar a compreensão do seu papel no legado radical da família e, por extensão, do papel da sua geração na história da esquerda nos Estados Unidos.

O paralelo entre a história da Esquerda Americana e a investigação familiar de Daniel é estabelecido logo nas primeiras páginas do romance, nas quais vemos o narrador chegando ao hospital psiquiátrico em que sua irmã está internada ${ }^{195}$. A relação entre a tentativa de suicídio de Susan e o passado político da família é sugerida pelo doutor Duberstein, médico da irmã de Daniel: “A expressão política comum era bastante difícil para ela - falou Duberstein. - A dissensão era traumática ${ }^{196}$."

Daniel sugere a origem política dos problemas psiquiátricos de Susan ao insinuar que sua irmã fora manipulada por um aparato de propaganda que a tornara moralmente deslocada da sociedade na qual vive: “Ah, Susy, minha Susyanna, que foi que você fez? Você é vítima da engrenagem da propaganda moral internacional! Fizeram de você um maníaco da velocidade moral! ${ }^{197 " \prime}$ (p. 18)

Adiante, o narrador revela que sua preocupação com os excessos de Susan é antiga e insinua uma ligação entre o destino de sua irmã e o fado negativo da família: "Her excesses have always seemed to render him contemplative. This is the worst she's been, the worst she's done; it has occurred to him, perhaps, that the pattern of our lives is deterioration, that the movement of our lives is toward death" (p. 13). A afirmação tautológica de que o movimento da vida é em direção à morte ganha a conotação política de fatalismo dentro do contexto da narração de Daniel. O uso do pronome "our" (nossas) em vez de "their" (deles) expande o padrão de deterioração de que Daniel fala a respeito da família Isaacson para um universo mais amplo. Da mesma forma, pode-se ter que o "our" da sentença inclui apenas a família Isaacson. A ambiguidade desse trecho reforça o movimento central do romance de vincular o plano geral da História ao destino

${ }^{195}$ Carol C. Harter e James Thompson propõem uma leitura do hospital no começo do romance como uma metáfora de abertura para o estado do país ao final dos anos 60. (E. L. Doctorow. Boston: Twayne Publishers, 1990, p. 30).

${ }^{196}$ No original: Ordinary political expression was difficult enough for her,' Duberstein said. 'Dissent was traumatic'. (p. 26).

${ }^{197}$ No original: Ah Susy, my Susyanna, what have you done? You are a dupe of the international moralist propaganda apparatus! They have made a moral speed freak of you! (p. 10). 
individual dos personagens, como é próprio do romance histórico, que, como vimos acima, Jameson define como gênero de ficção que se caracteriza justamente por promover, por meio da criação de personagens e de seu destino na narrativa, a intersecção engenhosa do plano público ou histórico com o plano existencial ou individual.

A intersecção entre a turbulenta década de 1960 e as perturbações do narrador é latente no texto, já visto, do último tópico da lista de "tópicos a serem levados em conta" $" 198$.

A metáfora bíblica do título do romance retorna nesse trecho. Daniel Isaacson sofre - como o Daniel da bíblia - com visões que exigem explicação e cuja decifração pode acarretar sérios riscos. Sobre esses riscos somos advertidos no trecho - discutido acima - em que Daniel explica a "dinâmica do pensamento radical" como uma cadeia de conexões cujo final dá na descoberta, pelo radical, da conexão entre a sociedade e sua morte. Outro alerta sobre os riscos do trabalho de decifração a que Daniel é levado está na sua percepção de que o conhecimento do radical sobre os mecanismos de funcionamento da sociedade contra o qual ele reage o torna um "criminoso da percepção". A expressão cunhada por Daniel aparece pela primeira vez no romance quando ele se recorda do treinamento político a que seu pai o submetia:

Lembro-me de seus sermões. Queria que eu me criasse direito. Combatia a sociedade para defender a minha alma. Trabalhava-me para combater as más influências da minha cultura. Era este o nosso relacionamento: ele me ensinava a ser um alienígena psíquico ${ }^{199}$. (pp. 43-44)

A posição ambígua de Daniel em relação ao passado radical da família aparece aqui no tom amargo com que ele se lembra do seu pai como alguém que o legou à posição socialmente perigosa de "criminoso da percepção" e "alienígena psíquico".

198 "The summer of 1967 was just beginning. There would be a wave of draft-card burning. There would be riots in Newark and Detroit. Young people in the United States would try a form of protest originated in this century by the Buddhist monks if South Vietnam. They would douse themselves with gasoline and light matches to themselves. They would burn to death in protest. But I, Daniel, was grieved, and the visions of my head troubled me and I do not want to keep the matter in my heart." (p. 17).

${ }^{199}$ No original: What I remember is the lectures. He wanted me to grow up right. He wrestled society for my soul. He worked on me to counteract the bad influences of my culture. That was our relationship - his teaching me how to be a psychic alien. (The Book of Daniel. New York: Random House, 2007, p. 34). 


\section{Intersecções: Daniel e a esquerda norte-americana dos anos 60}

O caráter ambivalente do ethos político do narrador aparece aqui de forma decisiva. Se o aprendizado político a que Daniel e Susan foram submetidos os tornou "criminosos da percepção" e "alienígenas psíquicos"; se, além disso, a última conexão que o radical estabelece é entre a sociedade e sua morte, então a sobrevivência de Daniel - em oposição à execução de seus pais e, sobretudo, à morte de Susan (sua companheira de geração) atestaria sua falta de radicalismo e engajamento. No entanto, a leitura do livro de Daniel - com todas as sofisticadas análises e percepções críticas do narrador - torna inaceitável a assunção de que tal narrativa tenha sido escrita por alguém que "tem o desenvolvimento político de um retardado ${ }^{200 "}$. O caráter criticamente produtivo dessa ambiguidade está na abertura que o ethos ambivalente do narrador cria - abertura que, lida alegoricamente, capta o impulso utópico de encontrar uma zona de convergência entre as gerações de radicais de esquerda em meio ao tumulto de vozes dos anos 60, que resultou na fragmentação da política em micropolíticas. Em última análise, não cabe julgar - como fazem Susan e Artie Sternlicht ${ }^{201}$ - o posicionamento radical de Daniel ou sua alienação política. O personagem Daniel - neto do socialismo da virada de século ${ }^{202}$, filho da Velha Esquerda Americana, vítima da repressão política dos anos 50 (a execução dos seus pais) e irmão de uma geração confusa entre as demandas do presente e as lições do passado (Susan não sabe o que fazer com o seu projeto de criação da Fundação Paul e Rochelle Isaacson para Revolução) - figura a tensão entre o desaparecimento e a continuidade do passado radical americano.

Os anos 60 marcam o início do chamado "pós-modernismo" e, com ele, o surgimento de novas formas da política. Fredric Jameson, em seu ensaio "Periodizando

\footnotetext{
${ }^{200}$ Comentário de Susan sobre Daniel na página 81 (versão em inglês).

${ }^{201}$ Artie e sua namorada questionam o posicionamento político de Daniel no trecho que segue: Which side are you on? / Which side are you on? / WHICH side ARE you ON? / WHICH SIDE ARE YOU ON? / They ended up singing the chorus right in my face. They broke themselves up. And I went home reacquainted with the merciless of radical temperament (p. 154).
}

${ }^{202}$ Ver o comentário sobre a avó de Daniel no começo do capítulo. 
os anos 60", descreve o surgimento dos microgrupos e da micropolítica e o crescente repúdio às formas de pensar totalizantes:

What will emerge is not merely a heterogeneity of levels henceforth, semiautonomy will relax into autonomy tout court, and it will be conceivable that in the decentered and "schizophrenic" world of late capitalism the various instances may really have no organic relationship to one another at all - but, more importantly, the idea will emerge that the struggles appropriate to each of these levels (purely political struggles, purely economic struggles, purely cultural struggles, purely "theoretical" struggles) may have no necessary relationship to one another either. With this ultimate "meltdown" of the Althusserian apparatus, we are in the (still contemporary) world of microgroups and micropolitics - variously theorized as local or molecular politics, but clearly characterized, however different the various conceptions are, as a repudiation of old-fashioned class and party politics of a "totalizing" kind ${ }^{203} \ldots$

A narrativa não permite que se delimite uma identidade política clara para Daniel - ao contrário do que acontece com Susan (militante da SDS), comparada pelo narrador à Rosa Luxemburgo. Embora alguns enxertos ensaísticos, intercalados à narração, tragam uma revisão da história da Revolução Russa que lida com os cadáveres no armário da esquerda $^{204}$ de forma cínica e desesperançada quanto à ideia de revolução - o que aproxima Daniel da postura iconoclasta da Nova Esquerda -, a tese da punição corporal como distinção de classe se aproxima de uma análise marxista clássica baseada na noção de conflito de classes, exemplarmente formulada na célebre passagem do manifesto comunista: "A história da humanidade é a história da luta de classes". No trecho a seguir, pode-se perceber a filiação epistemológica da tese de Daniel à tradição de análise marxista baseada no conflito de classes:

Podemos dizer que a base de todas as distinções de classe na sociedade é o castigo corporal. As classes são criadas pelo castigo corporal. $\mathrm{O}$ chefe autocrata de uma sociedade deriva seu poder do apoio não das massas, mas das classes superiores, ou da burocracia privilegiada, que financia o governo e divide as suas recompensas.

\footnotetext{
${ }^{203}$ JAMESON, Fredric. Periodizing the 60s. In: JAMESON, Fredric. The Ideology of Theory Essays 1971-1986 - Volume 2: The Syntax of History.Minneapolis: University of Minnesota Press, 1988.

${ }^{204}$ Alguns deles são: os julgamentos da década de 30 - conhecidos como o "Grande expurgo" stalinista -, que eliminaram os opositores de Stalin, dentre eles revolucionários antigos como Bukkarin; o pacto de não agressão entre Rússia e Alemanha nazista; as revelações sobre o regime stalinista feitas por Nikita Krutchev em 1956.
} 
Em contraste, a lealdade das massas é mantida apenas pela constante intimidação física. Enquanto perduram na história, as sociedades simbolizam sistemas complexos de castigo corporal em termos econômicos. É por isso que Marx usou a palavra "escravidão" para definir o papel das classes operárias sob o capitalismo. Escravidão é o estado de absoluta submissão ao castigo corporal. Nas épocas de transição, contudo, as classes dominantes restabelecem seu direito literal, não-simbólico, do castigo corporal sobre as classes inferiores, em geral em nome da lei e da ordem. O crime praticado por alguém de classe inferior nunca é contra outro ser humano, mas sempre contra a ordem e a autoridade do estado ${ }^{205}$. (pp. 141-142)

A noção do Estado como defensor de privilégios de classe - exemplarmente ilustrada por Marx no 18 Brumário - é retomada por Daniel logo no início do capítulo intitulado Starfish - em que ele investiga o julgamento de seus pais no contexto da Guerra Fria - quando ele trata das leis como expressão de interesses de classe:

A lei, seja qual for o seu nome, protege o privilégio. Falo da lei de qualquer estado que não alcançou o socialismo. A autoridade única da lei está na sua capacidade de impor-se por si mesma. Esta capacidade manifesta-se no Julgamento. Não poderia haver lei sem julgamento. O Julgamento é a finalidade da lei. E o castigo é a finalidade do julgamento - não se pode julgar ninguém, a menos que se assuma o poder de castigá-lo. (...)

O radical desperdiça a sua oportunidade, portanto, caso leve a sério as questões de seu julgamento. Se for condenado, é decisão do poder dominante que ele não pode ser tolerado. Se for considerado inocente é decisão do poder dominante que não se precisa temê-lo. O radical não deve discutir sua inocência, pois o julgamento não é coisa dele; deve discutir suas ideias ${ }^{206}$. (p. 196)

\footnotetext{
205 No original: We may say that the basis of all class distinctions in society is corporal punishment. Classes are created by corporal punishment, and maintained by corporal punishment. The authoritarian head of a society derives his power from the support not of the masses but of the upper classes or privileged bureaucracy which funds his government and divides its rewards. By contrast the loyalty of the masses is maintained only by constant physical intimidation. As societies endure in history they symbolize complex systems of corporal punishment in economic terms. That is why Marx used the word "slavery" to define the role of the working class under capitalism. Slavery is the state of absolute submission to corporal punishment. In times of challenge, however, the ruling classes restore their literal, unsymbolized right of corporal punishment upon the lower classes, usually in the name of law and order. The crime of someone in the lower class is never against another human being but always against the order and authority of the state. (pp. 129-130).
}

${ }^{206}$ No original: Law, in whatever name, protects privilege. I speak of the law of any state that has not achieved socialism. The sole authority of the law is in its capacity to enforce itself. That capacity expresses itself in Trial. There could be no law without trial. Trial is the point of the law. And punishment is the point of the trial-you can't try someone unless you assume the power to 
Considerando-se o caráter indeciso do narrador e as oscilações de tom de sua narração - da desconfiança ao cinismo, da seriedade ao drama - poderíamos supor que tais passagens constituam uma paródia do discurso da Velha Esquerda e assim não devam ser levadas a sério. O caráter ambivalente do narrador exige uma constante avaliação de suas afirmações. É claro que esse é um exercício necessário em toda narração em primeira pessoa, mas que se torna crítico com um narrador inconstante como Daniel. No entanto, o cruzamento dessas passagens com os outros trechos ensaísticos do romance e o exercício de tentar montar a tese do narrador por meio desses fragmentos mostra que nas passagens acima não há paródia, mas análises do pesquisador Daniel.

As análises de Daniel acima reproduzidas tomam a divisão da sociedade em classes como fato determinante do funcionamento das leis e do estado. Essa leitura dos privilégios de uma classe sobre a outra aproximam seu autor muito mais da Velha Esquerda dos anos 30 que da Nova Esquerda. Para ilustrar a distância entre as ideias contidas nos dois trechos acima e o credo da Students for a Democratic Society, reproduzo a seguir uma fala de Tom Hayden, um dos fundadores da SDS e tido (e também autoproclamado) porta-voz da Nova Esquerda Americana:

Eu não podia aceitar a visão marxista tradicional do governo como "comitê executivo da classe dominante", meramente um instrumento do programa dos negociantes. Tal visão ameaçava a premissa pela qual estávamos arriscando nossas vidas: de que podíamos registrar as pessoas para votar como um passo rumo a torná-las seres humanos livres e iguais, de que poderíamos conquistar, dentro do processo decisório existente, o reconhecimento para aqueles que estavam agora excluídos. $\mathrm{O}$ modelo marxista me pedia para acreditar que isso era uma ilusão, que o verdadeiro poder estava noutra parte, ou que a inclusão num sistema falido não era algo por que valia a pena morrer. Como um corolário para o descarte de reformas, ele tinha seu próprio mito o da revolução distante ${ }^{207}$.

punish him. (...) Therefore the radical wastes his opportunity if he seriously considers the issues of his trial. If he is found guilty it is the ruling power's decision that he cannot be tolerated. If he is found innocent it is the ruling power's decision that he need not be feared. The radical must not argue his innocence, for the trial is not of his making; he must argue his ideas.(p. 184).

207 HAYDEN, Tom. Reunion: A Memoir. New York: Random House, 1988 Apud SOUSA, Rodrigo Farias de. A Nova Esquerda Americana - De Port Huron aos Weathermen (1960-1069). Rio de Janeiro: Editora FGV, 2009, p. 95. 
No transcorrer de sua investigação, Daniel vai se mostrando cada vez mais cético com o otimismo reformista da Nova Esquerda. Ele entrevista pessoas envolvidas no julgamento de seus pais e estuda obras que tratam do caso e do contexto da Guerra Fria. No capítulo Starfish - já se aproximando do final da narrativa - Daniel demonstra ceticismo com a utilidade de se estabelecer uma verdade jurídica sobre a condenação de seus pais:

Robert Lewin continua procurando um meio de inverter $\mathrm{o}$ veredicto. Começo a sentir-me intolerante com os reformadores. Ascher dependendo das cortes de apelação. Começo a me sentir nauseado com os homens de boa vontade. Lidamos aqui com uma falha de comunicação [failure to make connections]. A falha de comunicação é cumplicidade. Reforma é cumplicidade.

É cumplicidade com o sistema ficar abismado com a estrutura moral desse mesmo sistema ${ }^{208}$. (p. 238)

Essa passagem cria uma conexão entre as afirmações de Daniel no trecho anteriormente citado - no qual ele concebe a lei dos estados não-socialistas como garantia de privilégios de classe e o caso Isaacson. Acreditar no sistema judiciário é, para Daniel, uma "failure to make connections".

A impaciência de Daniel com o reformismo de Ascher e Robert Lewin é compartilhada pelos estudantes franceses que, durante as agitações de maio de 68, registraram seu inconformismo nas paredes do Liceu Condorcet com os dizeres "Quando o último capitalista for enforcado nas vísceras do último reformista a humanidade será feliz ${ }^{209}$ ".

A "falha em fazer conexões" mencionada na passagem acima também se dá nas obras que tratam do julgamento dos Isaacson: uma vez que elas tentam estabelecer uma verdade jurídica sobre o caso, elas aceitam como pressuposto a imparcialidade do sistema jurídico americano para eliminar dúvidas sobre a condenação - confirmando, assim, a

\footnotetext{
${ }^{208}$ No original: Robert Lewin is still at work on a way to reverse the verdict. I am beginning to be intolerant of reformers. Ascher depending on the appellate courts. I am beginning to be nauseated by men of good will. We are dealing here with a failure to make connections. The failure to make connections is complicity. Reform is complicity. I It is complicity in the system to be appalled with the moral structure of the system.(pp. 226-227).

${ }^{209}$ QUATTROCCHI, Angelo; NAIRN, Tom. O Começo do Fim - França, Maio de 68. Rio de Janeiro: Record, 1998, p. 105.
} 
imparcialidade do sistema; ou provar a inocência do casal - apontando com isso uma falha no sistema que não o condena, mas o corrige e aperfeiçoa. Assim, Daniel aponta a inutilidade das abordagens do caso que focam o julgamento de um ponto de vista meramente jurídico:

Tenho diante de mim, nesta mesa, os seis livros escritos a respeito do julgamento de meus pais. Dois apoiam o veredicto e a sentença, dois apoiam o veredito, mas não a sentença, que consideram severa, e dois negam a justiça tanto da sentença como do veredicto. (...) Não existe diferença substancial nessas posições, para não aludir à $\operatorname{prosa}^{210}$. (p. 238)

A agudeza crítica do raciocínio de Daniel - e, não devemos esquecer, sua formação política forjada a fogo (eletricidade, para ele, é uma metáfora para fogo ${ }^{211}$ ) - o previne contra a armadilha de se engajar numa vã cruzada pela revisão histórica do julgamento e uma eventual admissão tardia da inocência dos Isaacson. Neste ponto da narrativa - já próximo do final do romance -, um Daniel cada vez mais radical demonstra incerteza quanto ao rumo de sua revisão histórica do caso Isaacson e se mostra cada vez mais imbricado na busca de mediações para entender o julgamento para além dos meros fatos jurídicos. Esse é o aprendizado dialético de Daniel e o romance resultante é o caderno de estudos desse estudante da história como processo.

Sua peregrinação em busca de entendimento prossegue até a Disneylândia ${ }^{212}$,onde, nas palavras da Daniel, a realidade histórica é submetida a um processo de redução radical - cenário do encontro do narrador com Selic Mindish, testemunha chave da história para a qual Daniel busca fechamento. Mindish é, a essa altura, um velho debilitado e incapaz de articular ideias. A contradição entre os comentários de Daniel -

\footnotetext{
${ }^{210}$ No original: I have before me on this table six books written about my parents' trial. Two support the verdict and the sentence, two support the verdict but not the sentence, which they find harsh, and two deny the justice either of the sentence or the verdict. (...) There is no substantial difference in these positions. To say nothing of their prose. (p. 227).

211 "Technology is the making of metaphors from the natural world. Flight is the metaphor of air, wheels are the metaphor of water, food is the metaphor of earth. The metaphor of fire is electricity". (Idem, p. 224).

${ }^{212}$ Para uma leitura do papel da Disneylândia como cenário em The Book of Daniel, Cf. AGILDO, João Rodrigo Lima. A crise da esquerda norte-americana em "The Book of Daniel", de E. L. Doctorow. 2006. 92f. Dissertação (Mestrado em Estudos Linguísticos e Literários em Inglês) Faculdade de Filosofia, Letras e Ciências Humanas, Universidade de São Paulo, São Paulo, 2006.
} 
acima expostos - sobre a ingenuidade do radical que se submete às regras do jogo e, ao fazê-lo, torna-se cúmplice do regime contra o qual luta ("É cumplicidade com o sistema ficar abismado com a estrutura moral desse mesmo sistema"), e a insistência na busca por uma verdade por trás do julgamento de seus pais reitera o caráter ambivalente do narrador e de sua investigação. Que essa busca encontre seu obstáculo final e incontornável na

figura de um velho demente e que esse encontro se dê na Disneylândia ${ }^{213}$ dão nota do processo de deterioração da consciência histórica da qual a forma desse romance é tradução, assim como a própria dificuldade do narrador em escapar dos dilemas que confronta na sua jornada dialética pelo passado radical americano.

\section{Leituras da descontinuidade}

O modo narrativo do romance oscila entre cinismo, ironia, observação crítica, deboche e investigação acadêmica de forma a criar um estado de permanente suspeita sobre as intenções do narrador em cada comentário que faz. No entanto, uma leitura que reconstrua a narrativa latente no mosaico de momentos da esquerda dispersos pelo romance - movimento que tento fazer aqui - sugere que o pensamento de Daniel consciência estruturadora da narração - organiza-se de forma caleidoscópica, como Fredric Jameson define o pensamento dialético. Dessa forma, a suspensão sobre as intenções e opiniões do narrador e o seu ethos ambivalente constituem a marca de um esforço de compreensão em busca de formalização. Guardadas as devidas ressalvas epistemológicas, é possível observar semelhante esforço de compreensão na forma da Fenomenologia do Espírito, de Hegel. Livro de difícil decifração, forneceu a base para a construção de explicações da história tão distintas quanto a dos jovens hegelianos de

\footnotetext{
${ }^{213}$ Para Baudrillard, o que atrai as multidões à Disneylândia é o "microcosmos social, o gozo religioso, miniaturizado da América real, dos seus constrangimentos e das suas alegrias (...) selecção do american way of life, panegírico dos valores americanos, transposição idealizada de uma realidade contraditória" Lá, "desenha-se, pois, por toda a parte, o perfil objetivo da América, até a morfologia dos indivíduos e da multidão. Todos os valores são aí exaltados pela miniatura e pela banda desenhada [quadrinhos]." (BAUDRILLARD, Jean. Simulacros e Simulação. Lisboa: Relógio D’Àgua, 1991, pp. 20-21).
} 
esquerda e a de Francis Fukuyama ${ }^{214}$. Fredric Jameson propõe uma leitura da Fenomenologia que tome as ambiguidades e hesitações da forma como "incertezas produtivas" - potenciais lições para o pensamento crítico contemporâneo, o qual tateia certezas num mundo em crise. Jameson explica a "política da forma" da Fenomenologia e seu interesse para nós hoje:

Yet what endows these textual moments with renewed interest for us today is their form fully as much as their content: for the very heterogeneity of the book has prevented any one of them from being fully assimilated to some homogeneous dimension of philosophical thought and discourse. They have not been able to be transformed into pure or coherent philosophical positions, into identifiable ideas or concepts, into reified tokens about which we can say that they represent Hegel's official thoughts or his "positions" on this or that. (...)

This productive uncertainty about the philosophical status of the Phenomenology is matched by equally productive ambiguities or hesitations on other formal or organizational issues ${ }^{215}$.

Esse exemplo de leitura da forma fornecido por Jameson ajuda a explicar a maneira como avalio o ethos ambivalente do narrador e o mosaico narrativo em The Book of Daniel. A “incerteza produtiva” sobre o status filosófico da Fenomenologia - analisada por Jameson do ponto de vista da forma - aproxima-se da "incerteza produtiva" sobre o status político do romance de Doctorow.

$\mathrm{Na}$ fortuna crítica desse romance, encontramos posições em polos opostos do espectro ideológico ${ }^{216}$. Divergências sobre o status político de The Book of Daniel

\footnotetext{
214 "We must at any rate read Absolute Spirit as a symptom rather than a prophecy, and thereby rescue the Phenomenology from its stereotypical reading as an out-of-date teleology. Indeed, in what follows I will argue that the "ladder of forms" of this work is as open-ended as one likes. How else to explain the persistence today of that opposition between left-Hegelians (such as Kojève) and right-Hegelians (Fukuyama and the triumph of American capitalism) that had already declared itself in the struggle for his system immediately after Hegel's own death?" (JAMESON, Fredric. The Hegel Variations: On the Phenomenology of Spirit. London, NewYork: Verso, 2010, p. 5).

${ }^{215}$ JAMESON, op. cit., pp. 7-8.

${ }^{216} \mathrm{Na}$ introdução do próximo capítulo ("História e figuração em Ragtime") apresento algumas das posições críticas mais comuns sobre os romances de E. L. Doctorow.
} 
aparecem também entre leitores de mesma linhagem crítica $^{217}$, o que evidencia a complexidade da forma nesse livro.

O já mencionado relato de Doctorow sobre o momento de crise no processo de criação desse romance e o resultante abandono de formas narrativas mais tradicionais em favor de uma abertura da forma evidencia a maturidade do romancista, que enfrenta as dificuldades da figuração e incorpora ao romance uma certa consciência da forma, um movimento autorreflexivo que se debruça sobre suas próprias limitações figurativas. Uma resposta de Doctorow sobre o processo de escrita de The Book of Daniel indica a maturidade de um autor aberto às hesitações e incertezas do processo de dar forma à experiência de um tempo convulso:

There's a certain way in which, in order to get our work done, we really have to be ignorant. We can't know too well what we're doing. If you know too well what you're doing, then writing simply becomes a matter of filling in. At its best, you write to find out what it is you're writing ${ }^{218}$.

A forma resultante desse trabalho de investigação do autor tem suscitado posições críticas variadas $^{219}$, que transitam do entusiasmo à desconfiança. A mais comum delas interpreta a fragmentação do romance como uma espécie de questionamento sobre os meios de construção da verdade histórica. Assim, a fragmentação da forma no romance

\footnotetext{
${ }^{217}$ Para Fredric Jameson, "E. L. Doctorow é o poeta épico do desaparecimento do passado radical americano" (Pós-Modernismo - A lógica Cultural do Capitalismo Tardio. São Paulo: Ática, 1996, p. 51). Michael Denning, depois de dizer que a Nova Esquerda Americana inaugura uma nova "estrutura de sentimento", localiza o filme Daniel - baseado no romance aqui estudado -, de Sidney Lumet, e os romances de E. L. Doctorow na "estrutura de sentimento" que gestou a Velha Esquerda Americana. Para Denning, esse filme o os romances de Doctorow são "encarnações da estrutura de sentimento da Frente Popular" (DENNIG, Michael. The Cultural Front - The Laboring of American Culture in the Twentieth Century. New York, London: Verso, 1997, p. 26).
}

${ }^{218}$ DOCTOROW. In: MORRIS, op. cit., p. 45.

${ }^{219}$ Uma das mais curiosas explica a forma desse e de outros "romances da Guerra Fria" como resultado de uma ruptura da temporalidade suscitada pela percepção da iminência do fim do mundo trazida pelo risco da guerra nuclear. Assim, vivendo sob o signo da destruição total, os escritores teriam uma relação problemática com a ideia de futuro, o que se traduziria em obras de marcadas "dificuldades textuais". Vejamos um trecho do argumento: "These texts reflect a paradigmatic change in the understanding of historical time and finitude brought about by the invention and widespread deployment of atomic and then thermonuclear weapons. (...) This unwitnessable fact of nuclear ending haunts these novels and leads, I argue, to their signature textual difficulties." (GRAUSAM, Daniel. On Endings: American Postmodern Fiction and the Cold War. Charlottesville: University of Virginia Press, 2011). 
serviria a um propósito de "desconstrução" da pretensão do autor de chegar a uma versão definitiva da história. É fato que a forma em The Book of Daniel fala da dificuldade de se figurar o processo histórico em determinada época, mas a leitura "desconstrucionista" trata essa impossibilidade como um dado universal, ou seja, não se pode chegar a uma versão definitiva da história em hipótese alguma, ou, alternativamente, existem infinitas versões que criam o rico panorama da vida e qualquer tentativa de reivindicar validade para uma versão totalizadora da realidade histórica é sinal de dogmatismo, e mesmo de espírito autoritário ${ }^{220}$. Um exemplo desse tipo de leitura da forma do romance de Doctorow afirma que o "malabarismo de estilos narrativos" usados pelo narrador sugere que nenhuma forma tem o "monopólio da verdade", e que essa "desconstrução do ato da escrita" funciona como um questionamento da "autoridade do autor" 221.

Críticos e leitores mais ingênuos sequer tentam buscar explicação para a forma desse livro difícil. Para estes, forma é uma questão de estilo e originalidade. Alguns tratam a fragmentação da forma como mímese do dilaceramento psicológico do narrador, marcado por traumas de infância. Esses leitores ignoram que o livro não é sobre Daniel (como mostrei ao falar do narrador) e que a hipótese do eu-dilacerado se desfaz diante da constatação do claro conteúdo político do livro, evidente, por exemplo, na abundância de trechos ensaísticos, como a longa seção intitulada "The True History of the Cold War". A dificuldade de críticos e leitores em lidar com a fragmentação da forma é sintomática. Ela aponta para uma incapacidade de se pensar algo como uma unidade e de se buscar explicações totalizantes capazes de encontrar conexões entre elementos díspares ${ }^{222}$.

\footnotetext{
${ }^{220} \mathrm{O}$ panorama intelectual que cria as condições de existência e sustenta o predomínio desse tipo de análise é descrito com precisão por Eric Hobsbawm: "Nas últimas décadas, tornou-se moda, principalmente entre pessoas que se julgam de esquerda, negar que a realidade objetiva seja acessível, uma vez que o que chamamos de 'fatos' apenas existem como uma função de conceitos e problemas prévios formulados em termos dos mesmos. O passado que estudamos é só um constructo de nossas mentes. Esse constructo é, em princípio, tão válido quanto outro, quer possa ser apoiado pela lógica e por evidências, quer não. Na medida em que constitui parte de um sistema de crenças emocionalmente fortes, não há, por assim dizer, nenhum modo de decidir, em princípio, se o relato bíblico da criação da terra é inferior ao proposto pelas ciências naturais: apenas são diferentes. Qualquer tendência a duvidar disso é "positivismo", e nenhum termo desqualifica mais que este, exceto empirismo.”(HOBSBAWM, Eric. Sobre História. São Paulo: Companhia das Letras, 1998, p. 8).
}

221 "If Daniel's juggling of narrative styles suggests that no one form has a monopoly on truth, this deconstruction of the practise of writing functions as a questioning of the authority of the writer." (SAVVAS, op. cit., p. 126).

${ }^{222}$ Adorno, ao comentar o desejo de escritores diletantes de forçar conexões mesmo onde elas não existam, fala do incômodo que a descontinuidade causa em quem não concebe a existência de um 
Uma hipótese mais plausível para a fragmentação da forma em The Book of Daniel é oferecida por Harter e Thompson, para quem a natureza fragmentária do livro reflete a perturbada busca da verdade pelo narrador ${ }^{223}$. Tal análise é insuficiente porque cai na armadilha de conceder demasiada importância à infrutífera busca de Daniel para estabelecer a verdade no caso que teve seus pais como protagonistas. O tragicômico encontro de Daniel com o doutor Mindish (elo final da cadeia que ligaria o narrador à verdade sobre seus pais) indica que esse caminho termina em uma rua sem saída. O fato de tal constatação ocorrer, como vimos, no improvável cenário da Disneylândia - onde um senil e mentalmente incapaz Mindish passa seus dias brincando nos carrinhos de batebate - reforça a inutilidade da busca de Daniel pela verdade atrás da condenação de seus pais. Outro erro dessa análise está em atribuir ao "perturbado" narrador toda a responsabilidade pela fragmentação do livro, como se um narrador mais equilibrado pudesse narrar de maneira mais linear e organizada. Novamente, proponho que - apesar do título - esse não é um livro sobre Daniel e suas "visões". A armadinha de se pensar o romance como somente um "livro de Daniel" e sobre Daniel está armada, mas há alertas de sua existência ao longo da narrativa, como vimos.

A hipótese da forma fragmentária como reflexo do eu-dilacerado é mais uma vez enfraquecida pela passagem a seguir, na qual Daniel, nas últimas páginas do livro, dirigese ao leitor para anunciar que é capaz e efetivamente irá descrever a execução de seus pais: "Deve supor que sou incapaz de descrever a eletrocução. Sei que existe um você. Sempre houve um você. VOCÊ. Eu lhe mostrarei que posso fazer a eletrocução ${ }^{224 "}$ (p. 309). O que se segue é uma descrição fria e detalhada da execução de Paul e Rochelle, que inclui detalhes macabros como cheiros, fumaça de carne queimada, poça de urina no

todo: "Os diletantes literários podem ser reconhecidos por seu desejo de juntar tudo com tudo. Suas obras conectam as frases por meio de partículas lógicas, mesmo que as relações afirmadas por essas partículas não sejam válidas. Para quem não é capaz de pensar algo verdadeiramente como uma unidade, qualquer coisa que sugira uma desintegração ou descontinuidade torna-se insuportável; apenas quem consegue apreender o todo é capaz de entender as cesuras..." (ADORNO, Theodor. Notas de Literatura I. São Paulo: Duas Cidades; Ed. 34, 2003, p. 144).

223، Thus much, if not most, of the novel's fragmentary nature reflects Daniel's disturbed pursuit of the truth. Apparently random shifts in point of view and frequent dislocations of the narrative line both embody the disorderly process of Daniel's troubled thought and reflect various narrative strategies." (HARTER, Carol C., THOMPSON, James R. E. L. Doctorow. Boston: Twayne Publishers, 1990, p. 33).

${ }^{224}$ No original: I suppose you think I can't do the electrocution. I know there is a you. There has always been a you. YOU: I will show you that I can do the electrocution. (p. 296). 
chão, excrementos e a necessidade de uma segunda tentativa para terminar a vida de Rochelle. Ainda na linha do eu-dilacerado, é possível argumentar que a frieza dessa descrição corrobora a perturbação do narrador. Mas a interlocução do leitor, com destaque para o reconhecimento por parte do narrador da existência de um "VOCÊ" que analisa, prejulga e julga a narração, denota uma consciência da forma que, como já mostrei, incorpora as expectativas e preconceitos do eventual leitor na construção do romance. Assim, Daniel não escreve para apenas para si, com intenção catártica. Isso fica muito claro na "Nota ao Leitor" acima estudada. A narrativa que lemos não é um relato íntimo de uma mente que tenta se conciliar com seus traumas e expiar suas culpas. Quando Daniel, no trecho acima, se dirige ao leitor para avisar que sabe da existência desse interlocutor da narrativa, há uma abertura do universo restrito das cogitações íntimas para o espaço aberto da arena pública. Mais do que isso, Daniel, novamente, parece prever a hipótese de o leitor implícito entender sua narrativa como um relato pessoal de dramas familiares e imaginar que ele não será capaz de reconstituir a dolorosa cena da execução de seus pais. Ao "fazer a execução" - de forma fria e detalhada, lembremos - Daniel parece tentar reafirmar um certo afastamento emocional e "objetividade" que também aparece nos trechos ensaísticos e nas constantes mudanças da primeira para a terceira pessoa, na qual ele fala de si como personagem.

\section{O mosaico narrativo de The Book of Daniel}

Em sua visita a Artie Sternlicht, Daniel acompanha a curiosidade de uma jornalista pelas ideias e pelos planos do radical performático. Entre as curiosidades que chamam a atenção da repórter está uma parede que contém uma série de imagens. A parede é fotografada. Ela também atrai o interesse de Daniel, que a descreve para leitor:

A parede é interessante - totalmente coberta com uma colagem de fotos, anúncios de cinema, posters e objetos reais. Babe Ruth correndo entre as bases, Marlon Brando de bicicleta, Shirley Temple de sapatos de dança, FDR, um biquíni coberto com spray dourado, Marylin Monroe na foto do calendário, Mickey Mouse, o Washington de Gilbert Stuart com um bigode a lápis, um boné da 
Legião Americana, Fred Allen diante de um microfone, Susan B. Anthony de boca franzida, Paul Robeson, Sammy Baugh dando um salto, Calvin Coolidge com penas de índio, uma batalha aérea da Primeira Guerra Mundial, um grupo de sentenciados trabalhando numa estrada, uma boneca antiga, uma garota copulando com um jumento, capas amarelas de "E o Vento Levou" e "Um Mundo Só", de Wendell Willkie, um diafragma recoberto de tinta prateada, um amontoado de pontas de cigarro, um poster de "A Morte do Caixeiro Viajante", Elvis Presley jovem, um negro enforcado numa árvore, um branco vendendo maçãs a 5 cents $-{ }^{225}$ (p. 148)

Essa “colagem" é mencionada em vários dos textos que analisam o romance. Geralmente, ela é vista como uma espécie de ilustração em miniatura da própria forma do romance, ele também, segundo alguns autores, uma espécie de colagem ${ }^{226}$.

Os elementos que compõem a "colagem" trazem uma gama variada de posições políticas. Na esfera da cultura, temos a conservadora Shirley Temple e o Mickey Mouse

\footnotetext{
${ }^{225}$ No original: The wall is interesting. It is completely covered with a collage of pictures, movie stills, posters, and real objects. Babe Ruth running around the bases, Marlon Brando on his bike, Shirley Temple in her dancing shoes, FDR, a bikini sprayed with gold paint, Marilyn Monroe on her calendar, Mickey Mouse, Gilbert Stuart's Washington with a mustache penciled on a real American Legion cap, Fred Allen in front of a microphone, pinch-mouthed Susan B. Anthony, Paul Robeson, Sammy Baugh throwing a jump pass, Calvin Coleridge in Indian feathers, a World War One dogfight, a chain gang working on the road, an antique doll, a girl making it with a donkey, browned book jackets of Gone with the wind and One World by Wendell Willkie, a diaphragm sprayed with silver paint, a cluster of cigarettes butts, a Death of a Salesman poster, a young Elvis, a black man hanging from a tree, a white man selling apples for 5 cents - (p. 135).

${ }^{226}$ Dois exemplos desse tipo de leitura da parede de Sternlicht: "But the terrible disparateness of the wall is thematically consistent with Daniel's own conclusions and his own book has a montage, if not a collagelike quality."(HARTER, Carol C., THOMPSON, James R. E. L. Doctorow. Boston: Twayne Publishers, 1990, p. 39) "From the first slip of the pen onward, we are reminded that these real stories, too, are only part of the narrator's scattered self-as-language (The Book of Daniel, Daniel as text). And the discontinuous form of the text, resembling at times nothing so much as the collage on Sternlicht's wall, lets us know we can proceed only by giving up the illusion that we can get wholly outside the forms that narrate us." (REED, T.V. Genealogy/Narrative/Power: Questions of Postmodernity in Doctorow's The Book of Daniel. In: American Literary History 4, 1992, p. 302. http://www.jstor.org/stable/489989). (Acessado em 01/01/2014)
} 
de um lado, e Paul Robeson ${ }^{227}$ e Marlon Brando de outro. Na política, vemos FDR ${ }^{228}$ junto a defensores do estado mínimo e do laissez-faire: Wendell Lewis Willkie e John Calvin Coolidge. Na literatura, temos, de um lado, "E o Vento Levou”, e, do outro, "A Morte do Caixeiro Viajante". Esse conjunto de elementos opostos do espectro político americano mostra que não há nada de aleatório nessa reunião. Por trás do aparente caos de referências expostas nessa colagem, há um princípio organizador: a formação de grupos antagônicos que, juntos, representam as tensões latentes nas mais diversas áreas da vida americana.

Daniel vai até o apartamento de Artie Sternlicht levado pela suspeita de que sua irmã planejava ir até lá para adicionar um novo item à "colagem": um pôster da época dos protestos contra a execução do casal Isaacson ${ }^{229}$. O pôster é achado por Daniel no carro de Susan estacionado no restaurante Howard Johnson em que ela tenta o suicídio. A importância do pôster para a investigação de Daniel é enfatizada na lista intitulada "Pontos a levar em conta" (p. 25), na qual esse item aparece como primeiro ponto na $\operatorname{lista}^{230}$. O pôster é retomado, significativamente, em um dos momentos de ironia do narrador sobre a construção de artefatos históricos e sobre a transformação de fatos

227 'Robeson's support of the Soviet Union, his fear of the spread of fascism, and his disgust with Western democracies for refusing to support Loyalist Spain were positions typical of many Western intellectuals of the thirties, a number of whom, however, became disillusioned by events. Robeson's position only hardened; he defended the purges, the nonaggression pact between Stalin and Hitler, Russia's war against Finland, America's nonintervention in 1940 and its intervention in June 1941 (after Hitler attacked Russia), and even the postwar Soviet occupation of Eastern Europe." (DIGGINS, John Patrick. The Rise and Fall of the American Left. New York, London: W.W. Norton \& Company, 1992, pp. 136-137).

${ }^{228}$ Franklin Delano Roosevelt.

229 “'I I think she was coming here, she was on her way here,' I tell them. 'I think she was bringing you material for your collage'. Baby stands in the doorway. 'Save the Isaacsons,' she says. 'That poster.'” (p. 150).

230 " 1 . The old picture poster that I found in Susan's Volvo, in the front seat, in a cardboard tube." (p. 17). 
históricos em itens colecionáveis ${ }^{231}$. Isso ocorre quando a narrativa é interrompida pela apresentação do pôster como uma "curiosidade histórica", um item para colecionar e divertir os amigos. Reproduzo essa passagem em inglês, pela maior expressividade do tom irônico do narrador no original:

\section{FIRE SALE! EVERYTHING MUST GO!}

One picture poster, 36 X 24, used in demonstrations. Like new! Black and white double portrait depicts Isaacsons two faces historical curiosity cheap very cheap worthless comes in its own up-yours tube corners slightly deteriorated weighted with pieces of plaster amuse your friends with this historical curio free them ${ }^{232}$. (p. 30)

Nessa passagem, o hábito de colecionar objetos históricos é alvo do sarcasmo de Daniel. Esse hábito e a maneira como se dá o consumo do passado na forma de antiguidades mercáveis é sintoma do mesmo processo de redução que o narrador Daniel identifica no tratamento dado à história na Disneylândia ${ }^{233}$.

Se lermos a "colagem" como um panorama de personagens e fatos relevantes da histórica americana no século XX, o projeto de Susan de adicionar o pôster com seus pais nesse quadro simboliza o seu desejo - expresso também na ideia da Fundação Paul e

${ }^{231}$ A descrição que o narrador faz do "processo radical de redução" da história operado pela maquinaria de fantasias da Disneylândia é um desses momentos. A seguir, está reproduzida a explicação do narrador sobre esse processo de redução: "We find this radical process of reduction occurring too with regard to the nature of historical reality. The life and life-style of slave-trading America on the Mississippi River in the $19^{\text {th }}$ century is compressed into a technologically faithful steamboat ride of five or ten minutes on an HO-scale river. The intermediary between us and this actual historical experience, the writer Mark Twain, author of Life on the Mississippi, is now no more than the name of the boat. Piracy on the high seas, a hundred and fifty years of harassment of European mercantile exploration and trade, becomes a moving diorama of all the scenes and situations of the pirate movies made by Hollywood in the thirties and forties. When the customer is invited then to buy, say, a pirate hat in one of the junk shops..." (p. 288).

${ }^{232}$ Em português: Liquidação! Liquidação Total! Um cartaz de $7 m$ por $8 m$, usado em comícios. Novinho! Um duplo retrato em preto e branco representando os Isaacsons curiosidade histórica barato muito barato sem valor vendido em tubos cantos ligeiramente corroídos seguro com pedaços de reboco divirta seus amigos com esta curiosidade histórica liberte-os. (p. 40).

${ }^{233}$ No capítulo "A História como hobby" do livro "Consumindo a História", Jerome de Groot comenta o colecionismo de objetos históricos como itens de consumo: "Antiques demonstrate a complex commodification of the past - the fetishisation of the object due in the main to its age and historical context. (DE GROOT, Jerome. Consuming History: historians and heritage in contemporary popular culture. New York: Routledge, 2009, p. 67). 
Rochelle Isaacson para Revolução - de encontrar um lugar para eles nessa história. O fato de que esse lugar seja um espaço indeterminado dentro de uma reunião de imagens diversas diz muito da dificuldade da tarefa de Susan. À essa "colagem" é negada até intenção artística: em explicação à jornalista sobre o processo criativo por trás de tal obra, Sternlicht revela que a "colagem" é apenas um monte de papel grudado na parede inicialmente com o propósito nada estético e muito concreto de tapar um buraco ${ }^{234}$. O fato de Susan morrer antes de conseguir incluir seus pais nessa "colagem" de fatos e personagens da vida americana no século XX indica o fracasso do seu projeto de situar o caso Isaacson em um quadro histórico mais amplo.

Daniel, mesmo estando em posse do pôster e visitando Sternlicht, não entrega o item para ser integrado à "colagem" - contrariando o projeto de sua irmã. Podemos supor que esse gesto indica a resistência de Daniel, historiador treinado, em permitir que o pôster - o qual representa, simbolicamente, a história de seus pais e de um passado de lutas - seja lançado como mais um item em uma reunião indefinida de figuras de esquerda e de direita, onde o legado dos supostos espiões atômicos ficaria disponível para apropriações dos dois lados. Essa recusa do narrador em lançar a história que investiga na indefinição da "colagem" revela a existência de um desejo de ordenação e de estabelecimento de relações que contradiz as leituras que veem nessa "colagem" um paradigma para o romance. Proponho, em vez disso, a noção de mosaico narrativo para descrever a estrutura de The Book of Daniel.

O mosaico é uma reunião de peças que, vistas de perto, são apenas elementos isolados, mas que, vistas em relação umas com as outras, formam um todo coerente. Já a colagem é uma reunião de peças que não procura necessariamente seguir um princípio de ornaginzação. Ela sustenta uma abertura proposital, um descompromisso com princípios organizadores.

Com isso, não pretendo dizer que o livro, reunindo fragmentos dispersos, cria uma imagem do todo. Isso não se dá, e é mesmo um projeto irrealizável integralmente, como

234 “'You're very casual about your work', the reporter says, 'but I think it shows immense talent. Have you ever had formal study?' / 'Well see,' the girl looks at Sternlicht and starts to laugh, 'actually if anyone deserves credit for my art it's Mr. Magruder.' / Sternlicht breaks up. 'Mr. Magruder is our landlord, and that's how I, $y$ 'know, started. Just to cover some holes in the wall. Paper is very good insulation."' (p. 136). 
nos lembra Fredric Jameson ao analisar $O$ Capital de Marx como um "supremo esforço dialético" para representar o capitalismo:

... every attempt to construct a model of capitalism - for this is now what representation means in this context - will be a mixture of success and failure; some features will be foregrounded, others neglected or even misrepresented ${ }^{235}$.

O mosaico resultante do esforço dialético de Daniel, mesmo que termine em um quadro indefinido, esconde um desejo de ordenação menos necessário à noção de colagem. É esse desejo de ordenação que pretendo evocar com o uso do termo mosaico, em oposição à noção de colagem (preferência da maioria dos leitores críticos dessa obra de Doctorow).

As palavras finais do romance ("Segue o teu caminho, Daniel, pois as palavras estão encerradas e seladas até o final dos tempos ${ }^{236 ”)}$ ) denotam um pessimismo e uma descrença em mudanças que têm dado fôlego para leituras do livro como uma ponderação sobre a impossibilidade de se chegar a um veredito da história. De fato, a morte de Susan, o encontro final com Mindish e o não-fechamento da revisão do julgamento dos Isaacson, a estéril busca de Daniel na Marcha ao Pentágono e o encerramento forçado da narrativa pelos acontecimentos de 1968 na Universidade de Colúmbia reforçam essa ideia.

No entanto, a narrativa resultante do esforço de compreensão de Daniel é uma tentativa de juntar os cacos de sua memória familiar e da história de seu país para montar um mosaico possível ${ }^{237}$. A interseção entre o plano familiar (a história da família

\footnotetext{
${ }^{235}$ JAMESON, Fredric. Representing Capital. London, New York: Verso, 2011, p. 6.

${ }^{236}$ No original: Go thy way Daniel: for the words are closed up and sealed till the time of the end.

${ }^{237}$ No poema "Catando dos cacos do caos", de Affonso Romano de Sant'Anna, é apresentada uma formulação lírica do problema que Daniel enfrente em prosa. Vale ler alguns versos desse poema: "Catar os restos e ossos / da utopia / ............ como de porta em porta / o lixeiro apanha / detritos da festa fria / e pobre no crepúsculo / se aquece na fogueira erguida / com os destroços do dia. /// Catar a verdade contida / em cada concha de mão, / como o mendigo cata as pulgas / no pelo / - do dia cão. /// Recortar o sentido / como o alfaiate-artista, / costurá-lo pelo avesso / com a inconsútil emenda / à vista. /// Como o arqueólogo / reunir os fragmentos, / como se ao vento / se pudessem pedir as flores /despetaladas no tempo. /// Catar os cacos de Dionisio / e Baco, no
} 
Isaacson) e o coletivo (a história dos diferentes momentos do passado radical americano), como vimos, constitui um dos elementos de construção desse mosaico possível. A imagem do fio vermelho, estudada nas primeiras páginas do capítulo, se intersecta com a alegoria do coração, o que evidencia que a aparência de colagem de elementos aleatórios do romance esconde uma teia de relações - intentadas ou realizadas - a qual constitui a tentativa de Daniel de se "imiscuir nos mecanismos profundos e complicados do universo" (p. 81) em busca de um sentido possível.

Um depoimento de Doctorow sobre a origem do romance reforça a ideia da intersecção de planos que se cruzam a partir da consciência dilacerada do narrador:

In the case of Daniel, it was a far different feeling. It was the characters and their complexity that moved me - the historical intersection of social and personal agony, history moving in Daniel, shaping his own pathology - all this had an enormous meaning and interest for $\mathrm{me}^{238}$.

O problema formal desse romance é o da continuidade. A forma possível é buscada e o mosaico resultante dessa tentativa fala do esforço dialético perceptível nas inúmeras conexões e mediações encontradas no romance, dentre as quais destaco algumas das já estudadas: entre a geração do narrador e a de seus pais; entre a morte dos pais e a morte de Susan; entre o sacrifício revolucionário de Paul e o de Bukharin; entre a loucura da avó e as condições materiais da sua existência; entre o significado da execução do casal Isaacson e as lutas em curso nos anos 60 (a frustrada intenção de Susan de inserir a imagem de seus pais na parede do apartamento de Artie); entre o castigo corporal e a distinção de classe (a tese que Daniel pesquisa); entre a Guerra Fria e a "política da porta aberta" promovida pelo Departamento de Defesa no pós-guerra; entre a internação de Susan num sanatório e a satisfação dos americanos com os fatos do tormento nacional russo...

mosaico antigo / e no copo seco erguido / beber o vinho / ou sangue vertido. /// (...) /// É um quebra-cabeça? ............ Então / de cabeça quebrada vamos / sobre a parede do nada /deixar gravada a emoção /// (...) /// Catar os cacos / do presente e outrora / e enfrentar a noite / com o vitral da aurora.

${ }^{238}$ DOCTOROW. In: MORRIS, op. cit., p. 79. 


\section{"The novel as a sequence of analyses": os princípios de organização da narrativa em The Book of Daniel}

Em passagem em que Daniel relata como ele imagina - já que não poderia, sendo criança na época, ter acompanhado o julgamento de seus pais - terem sido as reações e pensamentos de sua mãe durante o depoimento incriminador de Mindish, temos uma interrupção do relato em que aparece a frase solta "the novel as a sequence of analyses". Lembremos que o livro, escrito durante um dia de pesquisas de Daniel na biblioteca da Universidade de Colúmbia, por vezes apresenta um caráter de rascunho, de escrita em progresso, que remete o leitor de volta à biblioteca. Vejamos o trecho em que a frase aparece, no original em inglês, na qual a interrupção da narrativa é mais evidente:

A wry acknowledgment of this moment in the court room, in their lives, and she was to read in it the message not of a betrayer

the novel as a sequence of analyses. But what of the executioner? A quiet respectable man, now retired. He is in the Yonkers phone book

no not as betrayer begging forgiveness... ${ }^{239}$ (p. 281)

O trecho indica uma escrita em curso, que acompanha o pensamento pari passu. A presença da palavra "romance" neste trecho remete o leitor para fora do universo diegético criado na obra. Nesse universo, Daniel está na biblioteca tentando escrever sua tese, enquanto, na maior parte do tempo, escreve recordações, ponderações sobre fatos do seu passado, trechos ensaísticos diversos... A obra resultante é um romance para o leitor, enquanto que para Daniel é o resultado de um dia de errância escrita.

Além disso, a frase solta “o romance como uma sequência de análises" sugere um impulso de organização e um esforço de cognição paradoxalmente comunicados em passagem desconexa e disruptiva, o que ilustra o fato de que, nessa obra, o impulso de

\footnotetext{
${ }^{239}$ Em português: Um melancólico reconhecimento daquele instante no tribunal, em suas vidas. E ficou abismada ao ver que a mensagem não era a de um traidor.

O romance como uma sequência de análises. Mas, que dizer do carrasco? Um homem tranquilo e respeitável, agora aposentado. Seu nome está no catálogo telefônico de Yonkers.

não, não de um traidor suplicando perdão... (p. 293).
} 
encontrar elos de causalidade caminha pari passu com o desmonte da forma - tradução formal dos problemas e dificuldades de tal empreendimento.

O parágrafo seguinte ao trecho em que essa frase aparece começa assim: "There is a line in one of her last letters to him. The gambler has no rights. It is a non sequitur. It

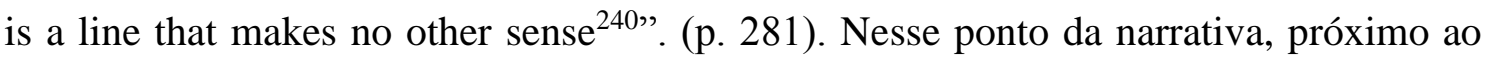
final do livro, Daniel está revendo os fatos do julgamento dos seus pais e tentando costurar uma versão definitiva do caso. Tenta fazer isso a partir dos pedaços recolhidos de sua memória, das entrevistas que fez ao longo do enredo com personagens como Robert Lewin, a esposa de Ascher, a filha de Mindish, um jornalista que cobriu o caso; e de suas leituras. A seção do romance em que essa narrativa sobre o caso Isaacson é construída por Daniel é chamada de "A teoria do outro casal" (p. 291). Segundo essa teoria, que Daniel tenta provar verdadeira, Paul e Rochelle teriam dificultado a própria defesa no julgamento com o propósito de proteger um outro casal, este sim envolvido em ações de espionagem de grande relevância para a União Soviética. Mindish conheceria o plano e teria agido conforme instruções russas. Daniel espera que Mindish confirme essa teoria e por isso o procura. O "non sequitur" que Daniel identifica em uma das últimas cartas de Rochelle traz uma ruptura da sequência que ele tenta reconstituir pela leitura das cartas de prisão de seus pais. Dentro de um "romance como uma sequência de análises", um non sequitur traria uma ruptura, um fio solto a partir do qual se poderia desfazer o embaraçamento dos vários fios que tecem essa trama complexa. Mas, o fato desse brilho de incoerência reveladora ter aparecido apenas nas últimas cartas de Rochelle - sem deixar, portanto, esperanças de novas revelações, já que sabemos o fim do casal - e de que, nas páginas seguintes, Daniel se encontra com um Mindish completamente incapaz de qualquer esclarecimento, frustram os planos do narrador de chegar a um veredito para a história de seus pais. Dessa forma, “o julgamento brilha para sempre com exatamente aquela ambiguidade perplexa de um verdadeiro romance... ${ }^{241}$ ".

Numa das passagens mais citadas e comentadas do livro, o narrador, no estilo enigmático presente em vários trechos soltos da narrativa, diz:

\footnotetext{
${ }^{240}$ Em português: Há uma linha numa das últimas cartas dela para ele, que diz: O jogador não tem direitos. É uma frase solta. É uma linha sem qualquer outro sentido. (p. 294).

${ }^{241}$ No original: ... the trial shimmers forever with just that perplexing ambiguity of a true novel...
} (DOCTOROW In: TRENNER, op. cit., p. 23). 
O que há de mais monstruoso é a sequência. Já que estávamos ali, por que precisávamos nos retirar, só para depois voltar? Não existirá algo que nos transfixe? Se ela vale a trepada, por que terei que trepar novamente com ela? Se a flor é bela, por que meu filho bebê não a olha para sempre? Paul arranca a flor e sai correndo, a flor pendente do cordão do sapato. Paul começa a segurar, segura, acaba erguendo a flor contra o céu, junto ao seu olho, contra o céu. Devoro com minha cabeça de cogumelo a boca do ventre da mãe de Paul. Quando atingimos o orgasmo, por que ele não se prolonga infinitamente? $\mathrm{O}$ monstruoso leitor segue de uma palavra para a seguinte. O mágico monstruoso ${ }^{242}$. (p. 258)

As análises sobre esse trecho se dividem, basicamente, em dois grupos: os que leem no trecho uma confirmação da textualidade, da autorreferencialidade ou do caráter metaficcional do romance. Para estes, o narrador repudia "sequências" em favor da abertura e da pluralidade de vozes e narrativas - a tese da narrativa como colagem é afim a esse tipo de leitura; para um segundo grupo, minoritário, Daniel considera a "sequência" monstruosa porque ela o levará a concluir o penoso quadro de lembranças expostas em sua narrativa com a execução de seus pais e o suicídio de sua irmã. Assim, a narrativa seria uma sequência de momentos dolorosos que cumina no trágico final que conhecemos. O narrador diz "Não existirá algo que nos transfixe?" como um lamento pela entropia da vida que escorre para a morte.

Seguindo a pista de que há um impulso de organização por trás da aparente arquitetura caótica do romance que o aproxima mais do caráter de construção do mosaico do que do caráter de dispersão da colagem, proponho uma leitura que justaponha - em vez de isolar - essa passagem às outras que venho analisando até aqui.

Juntando-se a investigação inconclusa de Daniel sobre o julgamento, o projeto interrompido de Susan de dar significado histórico - criando uma fundação, colando o pôster na parede de Sternlicht - ao martírio de seus pais, a tese que não se escreve e a própria narrativa, que termina na abertura dos três finais, temos um romance em que nada

\footnotetext{
${ }^{242}$ No original: What is most monstrous is sequence. When we are there why do we withdraw only in order to return? Is there nothing good enough to transfix us? If she is truly worth fucking why do I have to fuck her again? If the flower is beautiful why does my baby son not look at it forever? Paul plucks the flower and runs on, the flower dangling from his shoelace. Paul begins to hold, holds, ends hold of the flower against the sky, against his eye to the sky. I engorge with my mushroom head the mouth of the womb of Paul's mother. When we come why do we not come forever? The monstrous reader who goes on from one word to the next. The monstrous writer who places one word after another. The monstrous magician. (pp. 245-246).
} 
encontra fechamento. No entanto, temos, como já visto acima, uma série de tentativas de criar conexões, o que dá ao romance o caráter de "uma sequência de análises". A fragmentação da forma e as narrativas inconclusas dentro do romance falam eloquentemente do contexto de indefinição no qual a obra foi gestada.

A narração é interrompida pelo chamado da história ${ }^{243}$, e, ao final, Daniel não consegue amarrar todos os fios soltos do enredo. Mas no mosaico que restou incompleto dessa tentativa, vislumbramos trilhas de sentido e relações sugeridas por justaposição. A própria dificuldade de se construir um quadro coerente e representativo da teia de relações que o romance tenta tecer é tematizada pelo narrador em diversos momentos, como recordemos - na "Nota ao Leitor", na lista de "tópicos a serem levados em conta", no trecho "You pullin' out yo lit-er-ary map, mutha?". Mas é no mote "to get the picture" que essa dificuldade é referida mais claramente.

Essa frase pontua o enredo, e, geralmente, é dirigida a Daniel como um epílogo sarcástico de uma discussão ou de uma carta. Ela aparece em momentos de indefinição, em que o narrador é confrontado com um problema de interpretação ou quando dele é exigido um posicionamento diante dos fatos que analisa. Em um dos momentos mais significativos do romance (a "Nota ao Leitor"), Daniel dirige-se ao leitor implícito, como que compartilhando as dificuldades de análise que sua jornada dialética lhe impõe.

Mesmo quando a expressão aparenta figurar no enredo com seu sentido denotativo ("to get the picture" como visualizar, "imaginar a cena", como prefere o tradutor do romance), ela pode ser lida como senha para uma leitura política do grande quadro em que a imagem se insere. Isso acontece na descrição que Daniel faz do local onde sua irmã tentou o suicídio, um banheiro de beira de estrada em um restaurante Howard Johnson:

Daniel abriu caminho entre as famílias esfaimadas na ponta dos pés. Crianças aglomeravam-se diante da vitrine de chocolates. Havia pipocas no tapete. No lavatório dos homens, todas as cabines, à exceção de duas, exigiam moeda na fenda. Do outro lado daquela parede, Susan tinha aberto as veias e ficado de pé junto ao vaso até desmaiar. Tentou imaginar a cena. [He tried to get the picture]. O som das descargas perturbou-o. Observou numa parede um aparelho que por vinte e cinco cents oferecia a requintada escolha entre um lenço de papel pré-umedecido e impregnado de sabão, um pente esterilizado, uma bússola de Hong-Kong em forma

\footnotetext{
243 O fechamento da biblioteca da Univesidade de Colúmbia - evento histórico ocorrido em 1968 obriga Daniel a interromper a escrita do seu livro.
} 
de pneu de automóvel, dois ímãs de plástico, um cãozinho preto, outro branco, unidos no pacote pelos pés magnetizados ${ }^{244}$. (p. 38)

O cenário da tentativa de suicídio de Susan é repleto de conotações políticas. Lembremos que Susan nos é apresentada como uma representante da SDS (ou seja, uma militante da Nova Esquerda Americana) que busca encontrar espaço no novo contexto político dos anos 60 para o legado de seus pais, mas falha. Ela tenta o suicídio em uma filial de uma das maiores redes de hotéis, motéis e restaurantes dos anos 60, cuja rápida expansão serve de "case study" para a prosperidade que chegava às residências da classe média em forma de bens de consumo. A descrição de Daniel inclui uma amostra da enxurrada de produtos inúteis e descartáveis disponíveis à ânsia consumista crescente na sociedade americana do pós-guerra, alimentada por um período de crescimento da economia. O problema político que a promessa de felicidade trazida por esse período de prosperidade econômica e crescimento do consumo traz para a mobilização das forças progressistas é descrito por Diggins, em comparação entre o contexto econômico e político dos anos 30 e o dos anos 60:

But the real difference between the two generations of radicals is a matter more of context than of tactics. The historical context of the Old Left was the abundance of poverty; that of the New Left, the poverty of abundance. The Depression led older radicals to believe that history would do for them what they could not do for themselves ${ }^{245}$.

O espaço escolhido por Susan para a tentativa de suicídio, com todas as reverberações simbólicas desse ato para o enredo do romance, é um retrato da "pobreza da abundância" de que fala Diggins. O local que Susan escolhe para se matar (Howard Johnson - um dos templos da classe média consumista americana dos anos 60) não é

\footnotetext{
${ }^{244}$ No original: Daniel made his way through the hungry families standing on tiptoe. Kids swarmed in front of the candy display. Popcorn lay in the carpet. In the men's room all the crappers but two required a coin in the slot. On the other side of this wall, Susan had opened her veins and stood over the toilet until she fainted. He tried to get the picture. The sound of fountaining urinals distracted him. He noted on the wall a dispenser which, for twenty-five cents, offered the discriminating customer the choice of the pre-moistened soap-impregnated paper hanky, or a sanitized pocket comb, or a compass from Hong Kong in the form of an automobile tire, or two plastic dog magnets, one black, one white, stuck together in the pack by magnetized feet. (p. 28).
}

${ }^{245}$ DIGGINS, op. cit., p. 233. 
fortuito, uma vez que, como nos conta Daniel, "Toda a família compreende o peso mitológico dos $\operatorname{atos}^{246 ”}$ (p. 23). É nesse local que Daniel começa a sua investigação e é a partir daí que o mote "to get the picture" vai acompanhá-lo.

Outro mote muito presente no romance é o "they are still fucking us", já mencionado. Retomo-o aqui para reforçar que há mais elementos que ligam as partes aparentemente desconexas do livro - como num mosaico, na qual as peças são dispostas de determinada forma a fim de que, vistas juntas, produzam uma impressão de todo - do que sugerem as leituras de romance como variações orientadas pelo paradigma da colagem.

A parte do romance que mais claramente remete a um propósito de costurar, de tecer conexões, é a lista de "pontos a serem levados em conta". Já comentei alguns dos tópicos dessa lista, vinculando-os aos temas em análise. Agora, retomarei a lista como um todo, resumindo seus itens a fim de mostrar como ela constitui uma espécie de sumário do livro, um elemento organizador claro e indicativo do empenho de construção do narrador.

\section{1 - "O velho pôster que encontrei no Volvo de Susan, no banco da frente, num tubo de papelão ${ }^{247}$." (p. 25)}

O pôster com a imagem de Paul e Rochelle e a frase "liberte-os" indica para Daniel que dar sentido à história de seus pais é um elemento chave para a sua investigação. É o pôster que o leva a Artie e a um encontro com uma das faces do radicalismo nos anos 60 . A frase do pôster ("free them"), lida no presente de Daniel e Susan, pode sugerir a tarefa - referida por Susan explicitamente no livro - de libertar os Isaacson do limbo histórico a que sua história foi legada: abandonados pela Partido Comunista nos anos 50, pelo

\footnotetext{
${ }^{246}$ No original: Everyone in the family understands the mythological burden of acts. (p. 14).

${ }^{247}$ No original: The old picture poster that I found in Susan's Volvo, in the front seat, in a cardboard tube. (p. 17).
} 
temor do PC de atrair uma nova onda de perseguição com a associação a acusados de trair o país; não reconhecidos pela geração de radicais de esquerda dos anos 60 , por serem associados ao Partido Comunista ${ }^{248}$.

2 - “A cena terrível do Natal anterior, na família judia residente à Rua Winthrop, 67, Brookline, casas gêmeas construídas de modo a parecerem uma só, no estilo daquele bairro ${ }^{249}$." (p. 25)

A cena aqui referida é a da discussão entre Daniel e Susan sobre a criação da Fundação. Entender a visão de mundo de Susan é um dos objetivos de Daniel, que pensa poder, assim, ajudá-la. Entender a visão de Susan significa, dentro da constelação de posições políticas figuradas no romance, entender a proposta de parte significativa da Nova Esquerda, representada pela SDS. A ideia de se criar uma fundação para promover o pensamento revolucionário sugere, pelo exagero da contradição, a ingenuidade do projeto de mudança a partir da ordem estabelecida que marca a SDS: "Operar dentro do sistema para reformá-lo, ainda que mantendo um distanciamento crítico, era a premissa básica da $\operatorname{SDS}^{250}$."

Criar uma fundação - ou seja, um "aparato ideológico de estado" 251 - para promover o pensamento revolucionário seria visto como uma contradição pelo "modelo marxista" que orientava a Velha Esquerda.

\footnotetext{
${ }^{248}$ Com o exagero característico do personagem caricato que é, Artie Sternlicht expressa o sentimento de parte da esquerda nos anos 60 em relação ao PC americano e, por associação, à Velha Esquerda: "O Partido Comunista Americano atrasou a Esquerda cinquenta anos. Creio que trabalhavam para o FBI. É a única explicação. Conspiravam. Foram inventados por J. Edgar Hoover. Foram a sua maior invenção". (p. 164) No original: The American Communist Party set the Left back fifty years. I think they worked for the FBI. That's the only explanation. They were conspiratorial. They were invented by J. Edgar Hoover. They were his greatest invention. (p. 150).

${ }^{249}$ No original: The terrible scene the previous Christmas in the Jewish household at 67 Winthrop $R d$., Brookline, a two-family house built, in the style of that neighborhood, to look like a onefamily. (p. 17).

${ }^{250}$ SOUSA, Rodrigo Farias de. A Nova Esquerda Americana - De Port Huron aos Weathermen (1960-1069). Rio de Janeiro: Editora FGV, 2009, p. 105.

${ }^{251}$ Conceito de Louis Althusser.
} 


\section{3 - "Nossa avó louca e o negro grandalhão que mora no porão"252". (p. 25)}

O ponto de contato entre a avó de Daniel e Williams, o negro que vive no porão dos Isaacson, se revela no velório da avó, quando Daniel, em conversa com Williams, descobre que este era visitado pela senhora, que lhe trazia chá e conversa. Williams repreende Daniel por ter medo de sua avó e diz que a família nunca a entendeu. Também lamenta não poder ir ao enterro - intuitivamente, ele sabe o quanto a sua presença chamaria a atenção, um negro em um enterro de uma branca, imigrante judia - e diz que, se dependesse da falecida, ele certamente iria ao cemitério acompanhar o sepultamento.

O que aproxima as narrativas do negro e da velha imigrante judia é a história de exploração a que seus semelhantes foram - e continuavam sendo - submetidos em solo americano. Rochelle, filha da senhora judia, explica a Daniel a origem da loucura da avó:

É simples: vovó enlouquece quando já não consegue suportar o tormento de sua vida. Minha mãe relaciona então as desgraças da velha: os pais abandonados, cuja foto amarelada ela conserva numa gaveta, a morte do primeiro filho atropelado na rua, a morte das duas irmãs no grande incêndio, a morte do segundo filho, vítima da gripe, a morte do marido, meu avô, que me teria amado se fosse vivo. "O que o matou não foi a tuberculose. O que matou a ele e a todos foi a pobreza e a exploração, isto é, ser pobre e mantido nesta condição por pessoas que engordam e enriquecem à custa do trabalho alheio. Não é justo, é?

_ Não, mamãe.

_ Sua avó trabalhou como uma escrava a vida inteira. Para terminar de mãos vazias ${ }^{253}$. (pp. 80-81)

A referência à escravidão ("Your grandma slaved all her life. To end up with nothing." p. 69) para descrever a exploração a que a imigrante judia foi submetida durante

\footnotetext{
${ }^{252}$ No original: Our mad grandma and the big black man in the cellar. (p. 17).

${ }^{253}$ No original: It is simple: Grandma goes mad when she can no longer consider the torment of her life. My mother's catalogue of the old lady's misfortunes - the abandoned parents whose brown picture she still keeps in her drawer, the death of her first-born in the street, the death of her two sisters in the big fire, the death of her second-born from the flu, the death of her husband, my grandfather who would have loved me if he'd lived. "What killed him was not tuberculosis, what killed him and killed them all was poverty and exploitation, and that means being poor and being kept poor by people who grow fat and rich from your labor, It's not fair, is it?"

"No, Ma."

"Your grandma slaved all her life. To end up with nothing." (p. 69).
} 
a vida nos Estados Unidos cria mais um ponto de contato entre sua história e de Williams. Este é relegado a viver em um espaço da casa raramente visitado pela família - com exceção da avó - e que Daniel visita no dia do velório. Lá, o negro vive entre cinzas, poeira, lixo, ratos e baratas. Daniel tem a impressão de que aquele espaço é o território de Williams e assim descreve o local:

O porão cheirava a cinzas, poeira, lixo e ao veneno verde colocado nos cantos para matar ratos e baratas. Havia também o cheiro de Williams que enchia o porão como a sua atmosfera e que o [Daniel] aterrorizava - um arrasador cheiro a queimado, provando que o negro dominava o porão e que este lhe pertencia, embora sua família morasse na casa. Era o cheiro de sua ira constante ${ }^{254}$. (p. 101)

Ira constante e loucura são efeitos da opressão sofrida por esses dois indivíduos ao longo da vida. Uma leitura comparativa da história da exploração desses dois povos (negros e imigrantes) nos Estados Unidos pode levar a criação de pontos de contato e suscitar laços de solidariedade mais profícuos do que a divisão das narrativas e dos grupos e o isolamento político decorrente ${ }^{255}$. Considerando-se que cada um dos "tópicos a serem levados em conta" traz um subtexto político, o tópico aqui analisado parece sugerir justamente essa convergência de narrativas, o que significaria um movimento em direção contrária à política de identidades em nascimento dos anos 60 e que viria a aprofundar as diferenças de origem e de demandas dos diversos agentes políticos.

O tópico da aproximação dessas duas narrativas tem um significado político específico para Daniel. Considerando-se que a narrativa é interrompida em 1968, é verossímil pensar que Daniel, morador de Nova York, tenha acompanhado os conflitos

\footnotetext{
${ }^{254}$ No original: The cellar smelled of ashes, of dust, of garbage, and of the green poison in the corners for the mice and roaches. There was also the smell of Williams which filled the basement like its weather, which terrified him - an overwhelming burning smell which proved that Williams ruled in the cellar, that even though his family lived in the house, the cellar belonged to Williams. It was the smell of his constant anger. (p. 90).

${ }^{255}$ Diante da crescente hostilidade mútua entre negros e imigrantes a partir do final dos anos 60, Norman Podhoretz coloca a questão: "What share had these Italian and Jewish immigrants in the enslavement of the Negro? What share had they - downtrodden people themselves breaking their own necks to eke out a living - in the exploitation of the Negro?" (PODHORETZ, Norman, "My Negro Problem - And Ours," Commentary vol. 35, no. 2, February 1963. In: JUMONVILLE, Neil (ed.) The New York intellectuals reader. New York: Routledge, 2007, p. 333).
} 
entre negros e judeus que aconteceram em 1967 no Brooklyn e no Harlem. Neil Jumonville resume as relações entre esses dois grupos até a eclosão do conflito:

For much of the twentieth century blacks and Jews had felt an alliance as targets of discrimination in the United States, and Jews had extended help to blacks as lawyers and union bosses. But under the patina of this partnership there had been resentment on both sides. Jews, as Baldwin wrote, were businessmen and landlords, "they operate in accordance with the American business tradition of exploiting Negroes, and they are therefore identified with oppression and are hated for it." (Baldwin, Notes of a Native Son) (...) This mutual antagonism exploded in the Ocean HillBrownsville argument in Brooklyn in 1967 in which the predominantly Jewish teachers and union opposed the new community control of schools by black parents in those neighborhoods. This painful fight is usually acknowledged as the point at which black-Jewish relations disintegrated to a point of mutual contempt ${ }^{256}$.

O impulso de compreensão latente em todo o romance e visível nessa lista de tópicos é manifesto na indicação feita nesse tópico de número 3 que é preciso entender a hostilidade entre grupos e a dinâmica de divisão étnica e racial nos Estados Unidos como componente importante da formação da consciência de classe nesse país. Nathan Glazer destaca o "padrão de comunidades" como determinante na formação do que ele chama de "sub-comunidades americanas":

In America we have lived under a peculiar social compact. On the one hand, publicly and formally and legally, we recognize only individuals; we do not recognize groups - whether ethnic, racial, or religious. On the other hand, these groups exist in actual social fact. They strongly color the activities and lives of most of our citizens. They in large measure determine an individual's fate through their control of social networks which tend to run along ethnic, racial, arid religious lines. Even more, subtly, they determine a man's fate by the culture and values they transmit, which affect his chances in the general competition for the abstract signs of merit and money ${ }^{257}$.

\footnotetext{
${ }^{256}$ JUMONVILLE, Neil (ed.) The New York intellectuals reader. New York: Routledge, 2007, p. 327.

${ }^{257}$ GLAZER, Nathan, "Negroes \& Jews: The New Challenge to Pluralism," Commentary vol. 38, no. 6, December 1964. In: JUMONVILLE, Neil (ed.) The New York intellectuals reader. New York: Routledge, 2007, p. 349.
} 
Esse tema será retomado com força em Ragtime, onde veremos um importante episódio histórico em que trabalhadores imigrantes de diferentes origens se unem em favor de causas em comum, atendendo ao apelo de Big Bill Haywood no romance: "There is no foreigner here except the capitalists".

A questão da integração do negro aos movimentos revolucionários da esquerda nos Estados Unidos - o chamado "Negro Problem" - é um componente do quadro dos anos 30 traçado pelas memórias de Daniel e sugerido no tópico aqui analisado. James Weinstein, analisando a relação entre os negros e o Partido Comunista Americano, explica que "o entendimento do Partido da libertação do negro como uma questão agrária reforçou a sua concepção de si mesmo como o partido da vanguarda e fortaleceu sua oposição a movimentos negros revolucionários autônomos ${ }^{258}$ ". Os negros, vistos pelo partido como camponeses, só poderiam se organizar, segundo essa visão, em movimentos orientados por com uma consciência nacionalista burguesa ${ }^{259}$. Nessa época, a ideia de um movimento negro socialista independente era inconcebível. Os movimentos negros nacionalistas eram entendidos como obstáculos à mobilização das classes trabalhadoras $^{260}$.

As condições de trabalho ${ }^{261}$ e de vida de Williams na residência dos Isaacson lembremos, um casal de militantes de esquerda filiado ao PCA - e sua presença quase espectral na casa traduz simbolicamente a relação entre os movimentos negros e a esquerda nos anos 30. A presença do negro num dos sete "pontos a serem levados em conta" sugere a importância da narrativa desse personagem na constelação de forças que Daniel tenta retratar no mosaico que constrói. No entanto, Williams ocupa pouquíssimo

\footnotetext{
${ }^{258}$ WEINSTEIN, op. cit., p. 91. Tradução minha.

${ }^{259}$ Idem.

${ }^{260}$ Idem.

${ }^{261}$ Daniel lembra, por exemplos, dos dias em que um caminhão despejava seu carregamento de carvão na calçada e de como Williams transportava, munido de pá e carinho de mão, todo o carvão para o porão, trabalho pesado que ocupava o dia todo do negro.
} 
espaço no romance, o que simbolicamente reproduz a dificuldade de integração dos negros a um movimento político revolucionário unificado, movimento esse já pouco imaginável no quebra-cabeça de identidades e filiações que o romance traduz - formal e tematicamente - de maneira reveladora.

A presença periférica do negro na vida da família Isaacson é evidenciada, mais uma vez, na ida da família e de amigos ao concerto do artista negro Paul Robeson. Com a casa cheia de militantes de esquerda à espera do ônibus que os levará ao concerto, o negro é visto trabalhando, e é ignorado. Daniel se pergunta por que Williams não é convidado a ir ao concerto de um grande artista negro americano. Quando o ônibus chega, todos os militantes reunidos na residência dos Isaacson embarcam rapidamente e partem, deixando na casa apenas Williams e a avó.

Nas lembranças de Daniel, a presença espectral de Williams pela casa desperta medo e curiosidade. O negro é um mistério e um fascínio, que Daniel hesita em perscrutar de perto. Da segurança do seu quarto, ele acompanha os movimentos do negro lá embaixo: "No seu quarto, lá em cima, Daniel escutava às vezes as latas trovejando como uma tempestade subterrânea, uma tempestade que atiraria para o alto as fundações da $\operatorname{casa}^{262 \%}$. (p. 102)

$\mathrm{E}$ as fundações seriam abaladas, assim como em Ragtime as frases "There were negros, there were immigrants" são prólogo para o levante negro que se seguirá no enredo. Sabe-se do papel central do movimento por direitos civis (Civil Rights Moviment) na configuração política dos anos $60^{263}$. Figuras como Martin Luther King Jr. e Malcon

\footnotetext{
${ }^{262}$ No original: In his own room upstairs, Daniel sometimes heard the cans crashing around under his feet like a storm under the earth, like a storm that would raise the foundations of the house. (p. 91).

${ }^{263}$ Nathan Glazer, comparando o poder de reivindicação dos negros nos anos 30 e nos anos 60 , destaca a importância do movimento dos direitos civis na maior visibilidade do movimento negro a partir da década de 60: "As the Negro masses have become more active and more militant in their own interests, their feelings have become more relevant, and have forced themselves to the surface; and Jewish leaders - of unions, of defense and civil rights organizations - as well as businessmen, housewives, and home-owners, have been confronted for the first time with demands from Negro organizations that, they find, cannot serve as the basis of a common effort. (...) One important new element in the situation, then, is that the feelings of the Negro masses have become politically relevant and meaningful in a way that they were not in 1935 or 1943. In those years, too, the Negroes of Harlem rioted, and broke the show windows of the Jewish-owned stores, and looted their contents. But these earlier outbreaks - which in terms of the feelings involved were very similar to the outbreaks of last summer - were not tied up with a great civil rights movement." (GLAZER, op. cit., pp. 344-345).
} 
$\mathrm{X}$ mobilizaram grande quantidade de pessoas em torno da causa dos direitos civis. A maior visibilidade de questões raciais nos anos 60, em relação aos anos 30, é simbolicamente traduzida, no romance, em um dos três finais para a narrativa - o de número 1, chamado simplesmente "A CASA". Nele, retornamos com Daniel à antiga casa dos Isaacson, agora habitada por uma família de negros. Em uma leitura alegórica, poderíamos ter que a casa, agora ocupada por negros ("A casa é dele agora", diz o narrador), reflete uma mudança de perspectiva dos anos 30 (em que o negro Williams ocupa apenas o porão) para o presente de Daniel. Continuando a interpretar alegoricamente os dados do enredo, temos que a aparente vitória social dos negros simbolizada pela ocupação da casa dos Isaacson - é contrariada pela atual situação de degradação do bairro que Daniel conheceu na infância:

Ele mudou. A Cross Bronx Expressway corre como uma profunda trincheira pelo que costumava ser a Rua 174. Os velhos edifícios de apartamentos, um atrás do outro, rua após rua, erguem-se em sua própria fuligem, como uma cidade em ruínas enchendo-se de sujeira. Mas, gente ainda mora ali. Grandes sacolas de plástico cheias de lixo estão empilhadas como sacas de areia junto às paredes dos prédios. Os lixeiros estão em greve. O lixo espalha-se pela calçada. Caixas vazias de leite rolam pelas ruas. Jornais aderem às pernas. Grãos de café correm pelo pátio da escola como areia num deserto. A velha escola cor de púrpura continua de pé. Não é tão grande como eu a recordava ${ }^{264}$. (p. 313)

Ganhou-se a casa quando ela já não valia mais nada. O tópico que sugere a relação entre Williams e a avó de Daniel nunca é retomado explicitamente pelo narrador, como não o são os demais. As relações, nesse livro difícil, devem ser estabelecidas recolhendose peça a peça do mosaico a ser construído no jogo dialético do narrador.

4 - “Acompanhar os Lewins, talvez até o Turnpike e depois a Brookline. Lembre-se de que só depois de ter entrado no carro de Susan que você realmente compreendeu.

\footnotetext{
${ }^{264}$ No original: It has changed. The Cross Bronx Expressway runs like a deep trench through what used to be 174th Street. The old apartment houses, rank upon rank, street after street, stand in their own soot like a ruined city filling with dirt. But people still live here. Great plastic bags of garbage are piled like sandbags against the sides of the buildings. The garbagemen are on strike. Garbage spills over the sidewalk. Empty milk cartons blow across streets. Newspapers stick to the legs. Coffee grounds drift across the schoolyard like sand across a desert. The old purple school still stands. It is not as big as I remembered. (p. 299).
} 
Continuam a nos atormentar [They're still fucking us]. Você entende. [You get the picture]. Você é um bom rapaz, Daniel [Good boy, Daniel] ${ }^{265 \%}$. (p. 25)

Esse ponto reúne os três principais motes do enredo: "they're still fucking us", "[to] get the picture" e "good bye/good boy, Daniel ${ }^{266 ", ~ o ~ q u e ~ i n d i c a ~ q u e ~ a t e n c ̧ a ̃ o ~ d e v e ~}$ ser dada ao significado dessas frases repetidas no livro. A presença dos motes em um único ponto cria uma concentração de significado que a narrativa a seguir vai cuidar de desdobrar em partes compreensíveis, ou pelo menos tentar fazê-lo. Considerando-se o caráter de sumário dessa lista de "pontos", há coerência nessa apresentação dos motes num único tópico.

Além disso, esse ponto se relaciona ao primeiro, pois foi no carro de Susan que Daniel encontrou o pôster e, como o tópico sugere, "realmente compreendeu" [got the picture].

5 - "Contanto que não comece a pensar que está fazendo algo que precisa ser feito. Quero deixar isto bem claro, rapaz. Você é um traidor. Não existe objetivo barato no qual não empenharia o seu patrimônio. É o tipo de traidor que trai sem razão. Quem se sentaria aqui escrevendo tudo isto, brincando consigo mesmo, em vez de trabalhar - que acha, o professor Sukenick virá verificar se está realmente trabalhando? Acha que isso lhe importa? Ou está apenas à procura de outro pai? De quantos pais precisa um menino? Por que não sai à procura de um emprego? Por que não deixa cair algo pesado? Por que não algo pesado demais? Por que não faz alguma coisa para mostrar a Susan como se age?267" (p. 25)

\footnotetext{
${ }^{265}$ No original: Fleshing out the Lewins, maybe following them to the Turnpike and then to Brookline. Remember it wasn't until you got into Susan's car that it really hit you. They're still fucking us. You get the picture. Good boy, Daniel. (p. 16).

${ }^{266}$ São duas versões do mesmo mote. Às vezes, Daniel não sabe explicar qual delas ouviu.

${ }^{267}$ No original: Just as long as you don't begin to think you're doing something that has to be done. I want to make that clear, man. You are a betrayer. There is no cheap use to which you would not put your patrimony. You're the kind of betrayer who betrays for no reason. Who would sit here and write all this, playing with yourself instead of doing your work - what do you think, Professor Sukenick will come to see if you're really working? Do you think it matters to him? Or are you just looking for another father. How many fathers does one boy need? Why don't you go out and get a job? Why don't you drop something heavy? Why not something too heavy? Why not something to show Susan how it's done? (p. 17).
} 
A figura de Daniel como traidor é desenhada em vários momentos do enredo. Ela se relaciona ao ethos ambivalente do narrador, já que, quase sempre, aparece na forma de um questionamento sobre a posição política de Daniel. Isso ocorre, por exemplo, quando Artie e sua namorada cantam para Daniel uma música intitulada "De que lado você está". Ocorre, também, no "Daniel Termidor", acima discutido.

A questão da "traição" de Daniel está relacionada ao uso do "patrimônio" político que ele herda da família. O dilema do narrador em relação a esse "patrimônio" é explicitado, por exemplo, no episódio da escolha do sobrenome a ser anunciado no ato de devolução do cartão de convocação, analisado no começo do capítulo.

A relação entre "traição" e o "patrimônio" sobre o qual Daniel se debruça em seu livro fica mais complicada quando consideramos o fato de que seus pais foram julgados traidores da nação ${ }^{268}$. Embora Daniel seja visto por sua irmã como um traidor do seu passado radical, seu "patrimônio" pode ser entendido, dependendo do ponto de vista, como um de radicalismo político e militância ou um de traição aos interesses nacionais (filho de "traidores" que é). Assim, o sentido de "traição" no romance não se submete facilmente a uma definição.

A indecisão de Daniel, que permeia a narrativa e ganha diversas formas no romance, encontra na imagem do traidor mais uma expressão. O mesmo Daniel que se declara um traidor em várias ocasiões, é também o narrador empenhado em resolver o mistério em torno do julgamento de seus pais como traidores da pátria e, assim, redimilos.

A incerteza no romance quanto à traição de Daniel ao seu legado alegoriza a desconfiança de uma geração, a dos anos 60, quanto ao legado de lutas de várias gerações de radicais de esquerda nos Estados Unidos. Irving Howe, um dos New York Intellectuals, depois de diversas tentativas de diálogo com a liderança do grupo de jovens radicais que se formava nos anos 60, relata o sentimento de abandono do passado - tanto radical quanto liberal - que parecia marcar essa nova geração:

I felt that some of its spokesmen wanted not just to refute my opinions - that would have been entirely proper - but also to erase, to eliminate, to "smash" people like me. They wanted to deny our past, annul our history, wipe out our integrity, and not as people

\footnotetext{
${ }^{268}$ Embora a acusação que resultou na execução do casal tenha sido por espionagem, na memória coletiva eles integram o quadro dos traidores da pátria, ao lado de figuras do Lee Harvey Oswald.
} 
mistaken or even pusillanimous but as people who were "finished," "used up."269

A dificuldade de Daniel em definir o seu lugar tanto na história da família quanto na história do passado radical de seu país encontra expressão formal em trecho no qual o narrador discute o crime de "traição", em épocas e lugares diferentes. Em uma tentativa de escrever uma genealogia dessa ação criminosa (a única definida na constituição americana, como ressalta o narrador), Daniel vai dos soberanos Stuart e Tudor até os Founding Fathers. Ao final desse estudo - quando ele está próximo de tratar da traição no século XX - ele parece atingir um impasse a partir do qual a escrita se dissolve, como se os trilhos de sentido que vinha seguindo tivessem sumido e o raciocínio descarrilhado em uma confusão de signos mais ligados pelo som do que pelo sentido, como acontece em vários trechos que lemos de The Public Burning. Vejamos no original:

I say IF THIS BE TREASON MAKE THE MOST OF IT!
If this bee is tristante make the mort of it
If this be the reason make a mulch of it
If this brie is in season drink some milk with it
If this bitch is teasing make her post on it
If this boy is breathing make a ghost of him ${ }^{270}$
(pp. 167-168).

Todas essas questões povoam a cabeça de Daniel $^{271}$ e tornam o seu livro um ato hermenêutico. Esse aspecto do romance já foi observado por John Parks, para quem o

${ }^{269}$ HOWE, Irving. Problems in the 1960s. In: JUMONVILLE, Neil (ed.) The New York intellectuals reader. New York: Routledge, 2007, p. 325. O choque entre os jovens da geração dos anos 60 e a geração anterior aparece também, por exemplo, no diálogo entre Benjamin, personagem do romance The Graduate (1963) e seu pai: "Dad, we've got nothing to say to each other." "But we've got to, Ben." "We don't."

${ }^{270}$ Na tradução: SE HÁ TRAIÇAO, É APROVEITA-LÁ AO MÁXIMO! / Se a abelha é irritante, mate-a / Se esta é a razão, confunda-a / Se o queijo está fresco, beba leite com ele / Se a cadela provoca, deixe nela a sua marca / Se o garoto respira, faça dele um fantasma. (pp. 181-182).

${ }^{271} \mathrm{O}$ paralelo entre o narrador e o Daniel bíblico se baseia, basicamente, nos seguintes pontos de contato: ambos vivem em tempos conflituosos, violentos e de intensa perseguição a dissidentes (“...Daniel, Beacon of Faith in a Time of Persecution", p. 12); ambos têm "visões" sobre o mundo em que vivem e carregam o peso dessas revelações, como fica claro no trecho em que o narrador Daniel escreve pensamentos que ele imagina perturbarem o seu homônimo bíblico, mas que poderiam ser atribuídos aos dois Daniels: "I, Daniel, was grieved in my spirit in the midst of my body, and the vision of my head troubled me... My cogitations much troubled me, and my countenance changed in me: but I kept the matter in my heart." (p. 12). A presença do mote "keep the matter in the heart" no trecho explicita a ligação de Daniel com os conflitos internos que ele, na passagem, atribui ao personagem bíblico. Sobre a analogia da figura do narrador com o seu 
texto resultante do embate do narrador com seu legado e seu presente é um "ato de hermenêutica cultural ${ }^{272}$ ", e por Geoffrey Gait Harpham, que vê a composição da narrativa de Daniel como uma epistemologia ${ }^{273}$.

Ainda no ponto de número cinco, vemos o narrador verbalizar a moldura literária que vai conter o mosaico narrativo criado por ele: "Quem se sentaria aqui escrevendo tudo isto, brincando consigo mesmo, em vez de trabalhar". Sendo escrito na biblioteca de uma universidade Ivy League por um estudante de pós-graduação, o texto é composto em um ambiente que é expressão do WASPestablishment norte-americano. No entanto, o texto escrito não é nada como uma tese formatada seguindo os padrões universitários americanos. Pelo contrário, a forma resultante é um mosaico de conteúdos diversos, muitos dos quais indesejáveis, inconvenientes ou até subversivos da ordem que uma universidade como Columbia, no geral, representa: perversões pessoais, confissões,

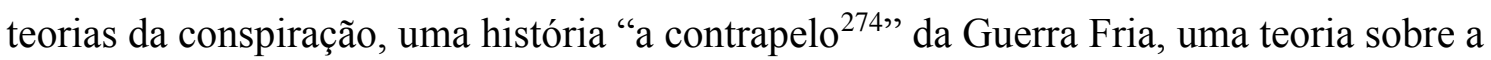
relação entre castigos corporais e a manutenção de privilégios de classe na história mundial etc...

homônimo bíblico, Doctorow diz: "Now the fact that because he was named Daniel he had a relationship to the biblical Daniel I didn't realize until I found him, my Daniel, going into the Bible to look up the original. In effect, I think there is a possible analogy there, because he does interpret the prevailing dreams of his society - a society that has had the power to destroy his parents. And in the act of interpretation, his book, he manages to survive, whereas his sister does not." (DOCTOROW. In: MORRIS, op. cit., p. 121).

${ }^{272}$ PARKS, John G. The Politics of Polyphony: The Fiction of E. L. Doctorow. Twentieth Century Literature, Vol. 37, No. 4 (Winter, 1991), pp. 454-463 Published by: Hofstra http://www.jstor.org/stable/441658. (Acessado em 29/06/2013)

${ }^{273}$ HARPHAM, Geoffrey Gait. E. L. Doctorow and the Technology of Narrative. PLMA 100, no. 1 (1985): 81-95.

${ }^{274}$ No sentido da célebre formulação de Walter Benjamin, explicada assim por Michael Lowy: "Escovar a história a contrapelo - expressão de um formidável alcance historiográfico e político - significa, então, em primeiro lugar, a recusa em se juntar, de uma maneira ou de outra, ao cortejo triunfal que continua, ainda hoje, a marchar sobre aqueles que jazem por terra". (LOWY, Michael. Walter Benjamin: aviso de incêndio - uma leitura das teses "Sobre o conceito de história". São Paulo: Boitempo, 2005). 
O cenário escolhido para a composição do livro é, não coincidentemente, o campo de batalhas preferencial da Nova Esquerda Americana ${ }^{275}$. A universidade como instituição foi alvo da revolta de estudantes nos protestos de Maio de 68 na França ${ }^{276}$. Já em abril do mesmo ano, a Universidade de Colúmbia ${ }^{277}$ havia sido tomada por estudantes em um movimento liderado pela SDS e que, para muitos, representou o começo de uma virada a qual levaria a Nova Esquerda a se desintegrar em grupos com posições inconciliáveis, como os Weathermen, cuja posição em favor do uso da violência para a tomada do poder batia de frente com a noção de "democracia participativa", tão cara a SDS e explícita na Declaração de Port Huron, de $1962^{278}$. O quadro de incertezas que se

275 “... the New Left introduced a novel form of radical violence: the campus confrontation. (...) ... the college campus was the one place where it could claim a record of successful conquests". (DIGGINS, op. cit., p. 249).

${ }^{276}$ Como nos contam pichações como esta, nos muros de Nanterre: "Professores, vocês estão velhos"; ou esta, num auditório da mesma cidade: "Vamos abrir os portões dos berçários, universidades e outras prisões". (QUATTROCCHI, Angelo; NAIRN, Tom. O Começo do Fim França, Maio de 68. Rio de Janeiro: Record, 1998, respectivamente, páginas 23 e 27).

${ }^{277}$ Para compreender melhor a importância dos eventos de 1968 na Universidade de Colúmbia fundamentais para o romance aqui estudado - conferir: Underground: my life in SDS and the Weathermen, Mark Rudd, Harpercollins, 2009 /Up against the wall motherf**ker: a memoir of the sixties with notes for the next time, Osha Neumann, Seven Stories Press, 2008 / Up against the ivy wall: a history of the Columbia crisis, Jerry L. Avorn, New York: Atheneum, 1969 / Six weeks that shook Morningside, Columbia College today, vol xv, no. 3 (spring 1968) / Crisis at Columbia: report of the fact finding commission appointed to investigate the disturbances at Columbia University, The Cox Commission Report. New York: Vintage Books, 1968 / Confrontation on campus: the Columbia pattern for the new protest, Joanne grant, New York: Signet Books, 1969 / The Strawberry Statement, Kunen, James, Simon, Wiley. John \& Sons, Incorporated, 2006 / Police on campus: the mass police action at Columbia university. New York: Temco Press, 1969 / Looking good, Maillard, Keith, Aberta: Brindle \& Glass, 2006 / Busy dying, Obenzinger, Hilton, Tuscon, Arizona: Chax Press, 2008 / With the Weathermen, Stern, Susan, Rutgers University Press, 2007 / Flying close to the sun, Wilkerson, Cathy, New York: Seven Stories Press, 2007 / Trespassers, Willis, Meredith Sue, Maplewood, New Jersey: Hamilton Stone Editions, 1997.

278“'A mudança de caráter da SDS é bem ilustrada pela frase de Carl Davidson, um de seus altos representantes, em 1967: 'Os tempos me dizem que o que devemos fazer desta vez é destruir'. E destruir eles foram: já em fins de 1967, a SDS advogava o uso da força contra a presença de recrutadores militares nos campi universitários; em seguida, vieram as turbulências de 1968, em algumas das quais membros da SDS teriam papel fundamental, como a tomada da Universidade de Colúmbia, levando um dos principais autores da Declaração de Port Huron, Tom Hayden, a declarar que os militantes eram agora 'guerrilheiros no terreno da cultura' e que seria preciso fazer os EUA mudarem por meio de 'duas, três, várias Colúmbias'. As referências a pensadores nativos, como C. Wright Mills e Arnold Kaufman, deram lugar a citações do revolucionário 'Che' Guevara e de Mao Tsé-tung, entre outras figuras do movimento comunista internacional; as análises sofisticadas e abertas a discussão foram trocadas por uma leitura que reduzia a complexidade do mundo a uma luta maniqueísta entre 'imperialistas' e 'revolucionários'. A fragmentação final se daria em 1969, quando a organização dividiu-se em facções, uma das quais, 
configura nos eventos de 1968 aqui mencionados é o pano de fundo para o melancólico final do romance. A "angústia pungente ${ }^{279 "}$ que Fredric Jameson diz marcar a experiência da leitura dos principais romances políticos de Doctorow para simpatizantes da esquerda encontra no final de The Book of Daniel sua expressão mais clara.

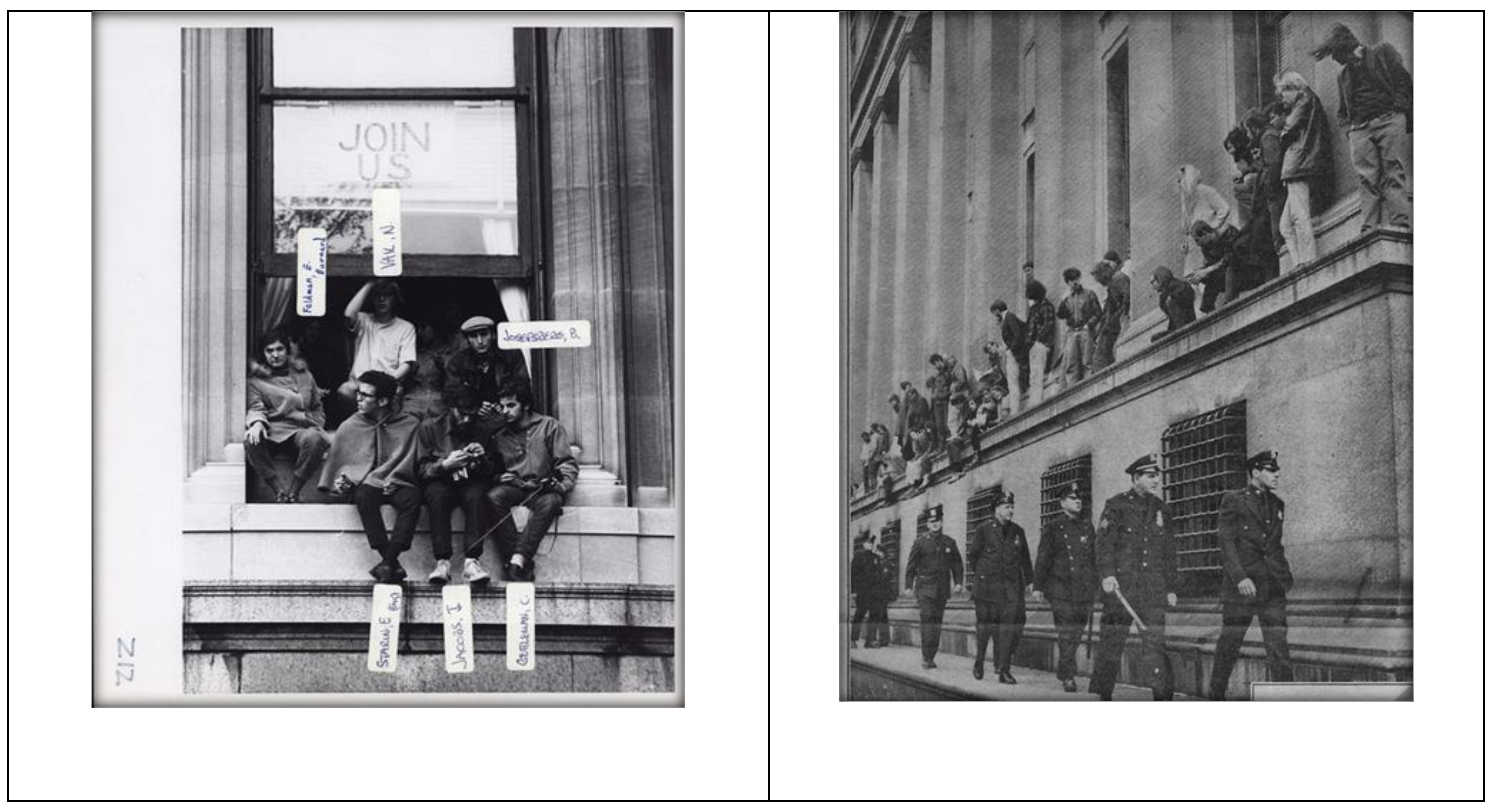

A biblioteca da Universidade de Colúmbia, tomada por estudantes.

http://www.columbia1968.com/

O ponto de número cinco é o mais extenso da lista, o que também sugere o papel central na narrativa de três questões esboçadas por esse ponto, lembremos: Daniel como traidor ("You are a betrayer"); a busca por orientação e filiação em um momento de crescente pulverização das lutas políticas ("Are you just looking for another father. How many fathers does one boy need?") e o dilema de Daniel entre se integrar, como professor universitário, a uma rotina de classe-média liberal ou se revoltar ("Why don't you go out

os Weathermen (ex-Revolutionary Youth Movement I), defenderia explicitamente a derrubada violenta do Estado norte-americano, recorrendo a ações armadas e atentados à bomba para atingir esse fim". (SOUSA, Rodrigo Farias de. A Nova Esquerda Americana - de Port Huron aos Weathermen (1960-1969). Rio de Janeiro: Editora FGV, 2009, p. 21).

279 JAMESON, Fredic. Pós-Modernismo - A lógica Cultural do Capitalismo Tardio. São Paulo: Ática, 1996, p. 51. 
and get a job? Why don’t you drop something heavy?"). Sobre essa última questão, lembremos que ela se apresenta na narrativa sob diferentes faces, como na "dialética da libertação" (discutida acima), no mote "Daniel is a good boy", e no contraste que Daniel vê entre sua mulher (a qual deseja vê-lo estabelecido como professor numa pequena universidade do interior) e sua irmã (a qual o conclama à luta política), explicito na passagem em que ele confronta Susan:

[Susan] Era Rosa Luxemburgo olhando para Daniel através dos óculos de vovó, de fina armação dourada, como se estivesse nos portões de outra cidade. Seus indômitos olhos azuis tocaram-lhe o coração como o badalar de um sino. Ele sentiu, naquela situação, a pobreza da escolha de sua mulher ${ }^{280}$. (p. 90)

Os dois pontos finais da lista mencionam o encontro com Artie e a criação da Fundação Isaacson, assuntos já analisados em outra parte do capítulo. O que cabe ressaltar aqui sobre essa seção de nome "pontos a levar em conta" é o seu caráter de síntese das tensões e problemas que o narrador vai confrontar na construção de seu livro. Se pensarmos esse romance como um esforço de mapeamento das posições políticas em jogo nos anos 60, esse pequeno trecho traz alguns dos caminhos que serão trilhados pelo narrador em sua tortuosa jornada.

A divisão do livro em quatro partes é outro elemento que confere alguma sustentação ao mosaico que esse romance é. Essas partes, chamadas de livros e numeradas em sequência, são: Memorial Day, Halloween, Starfish e Christmas. As variações da terceira para a primeira pessoa, do presente para o passado, do texto narrativo para o dissertativo, do modo irônico para o dramático ocorrem em todos os quatro livros. O que

\footnotetext{
${ }^{280}$ Destaque meu. No original: ...she was Rosa Luxemburg glacing at Daniel through her granny glasses of thin gold as if from the gates of another city, her fearless blue eyes striking his heart like the tolling of a bell. Daniel felt in this situation a poverty in his choice of wife. (pp. 78-79).
} 
os diferencia e justifica a divisão do romance em partes, ainda que precariamente, é uma concentração de certos temas em alguns deles. Foi observado ${ }^{281}$ que três dos livros recebem nomes de datas comemorativas: Christmas - um tradicional feriado religioso; Halloween - tradição de raízes pagãs (neste livro, concentra-se a maior parte das reflexões de Daniel sobre a chamada "caça às bruxas", como ficou conhecida a perseguição à esquerda durante o Macarthismo) e Memorial Day - um feriado patriótico em memória daqueles que morreram em defesa da nação. Se entendermos o patriotismo como uma espécie de religião cívica ${ }^{282}$ nos Estados Unidos, teremos um vínculo entre esses três livros e a metáfora bíblica explícita no título do romance. O terceiro livro (Starfish) não é uma data comemorativa, o que lhe confere um caráter disruptivo. Nele, acompanhamos o julgamento dos Isaacson e, no final, a participação de Daniel na Marcha ao Pentágono. Há, na figura da "Estrela-do-Mar" uma espécie de "profundidade de campo" que se aproxima do uso desse elemento de construção narrativa no projeto estético de Orson Wells em Cidadão Kane. Starfish remete simultaneamente a uma série de significados que ligam tempos e lugares diferentes. Ligam Susan, a condenação de seus pais, a bomba atômica, a Guerra do Vietnam. Não é coincidência que nessa parte do livro estejam juntos o episódio da Marcha ao Pentágono, a julgamento dos Isaacsons, o longo trecho sobre a história da Guerra Fria e a passagem sobre narrativa e "sequência". Vejamos como todas essas camadas de significado se unem na figura da estrela-do-mar.

A primeira menção a essa figura no capítulo relaciona esse ser marinho ao estado de paralisia em que Susan se encontra na cama do hospital psiquiátrico: "Hoje Susan é uma estrela-do-mar. Pratica o silêncio da estrela-do-mar. Há poucos silêncios mais profundos que o da estrela-do-mar. Não há muitas gradações de vida inferiores a isto, antes que a vida desapareça ${ }^{283 " \prime}$ (p. 219).

A figura da estrela-do-mar remete também ao julgamento dos Rosenberg - e, por consequência, ao contexto de polarização ideológica sob o qual ele se desenrolou - por meio de uma aproximação visual dessa figura com a principal evidência usada pela

\footnotetext{
${ }^{281}$ TOKARCZYK, 2000, p. 72 e DETWEILER, 1996, p. 69.

${ }^{282}$ HOBSBAWN, Eric. A Era dos Impérios (1875-1914). São Paulo: Paz e Terra, 2011, p. 239.

${ }^{283}$ No original: Today Susan is a starfish. Today she practices the silence of the starfish. There are few silences deeper than the silence of the starfish. There are not many degrees of live lower before there is no life. (p. 207).
} 
acusação para provar o crime de espionagem. Trata-se da "Evidência número 6", um esboço supostamente feito por David Greenglass, irmão de Ethel e testemunha de acusação, de parte da bomba atômica. O desenho lembra o formato de uma estrela-domar:

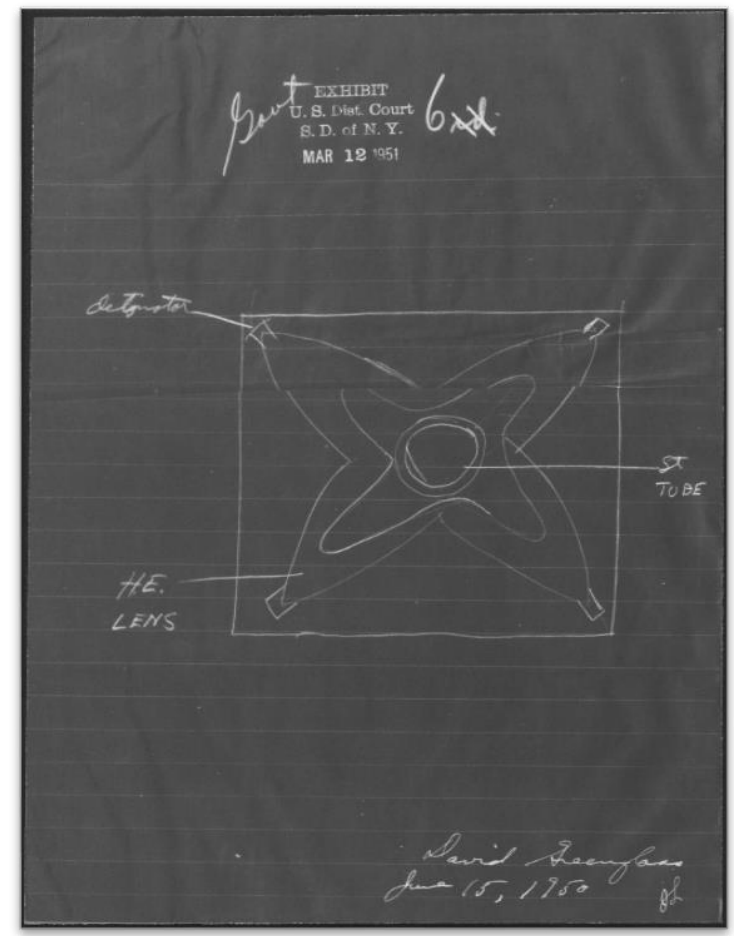

\section{U.S. vs. Julius \& Ethel Rosenberg and Martin Sobell, Government Exhibit 6, Lens} Mold Sketch. (In: TOKARCZYK, 2000, p. 79).

O vínculo entre a figura acima e a estrela-do-mar se torna mais forte se lembrarmos que é nessa parte do romance que Daniel esmiúça o julgamento de seus pais, consultando pessoas envolvidas diretamente no caso e revendo provas e argumentos da acusação e da defesa.

Mais óbvia é a associação de formas entre a estrela-do-mar e o Pentágono, cenário final dessa parte do romance. Lá encontramos Daniel, ensanguentado, dizendo como é mais fácil ser um revolucionário no presente do que no tempo de seus pais, os quais foram executados em vez de espancados. O significado político e simbólico desse evento histórico, no qual Daniel tenta tomar parte, não era facilmente apreendido por seus 
participantes $^{284}$. No entanto, havia entre os manifestantes uma percepção da importância daquele evento, o que levou Norman Mailer a cogitar que tal confrontação reavivaria o "estrondo de antigos trovões, antigas paixões para o coração estéril da Esquerda americana $^{285}$ ". Mailer, num rasgo de entusiasmo que dá bem a medida do significado da Marcha para os seus participantes, compara esse evento à Revolução Francesa e à Guerra Civil Americana, momentos que suscitaram verdadeiros cortes epistemológicos:

...but here, walking with Lowell and Macdonald, he felt as if he stepped through some crossing in the reaches of space between this moment, the French Revolution, and the Civil War, as if the ghosts of the Union Dead accompanied them now to the Bastille (...) the cold flame of a perfectly contained exaltation warmed old asthmas of gravel in the heart, and the sense that they were going to face the symbol, the embodiment, no, call it the true and high church of the military-industrial complex, the Pentagon, blind five-sided eye of the subtle oppression which had come to America out of the very air of the century ${ }^{286}$.

Na contramão do entusiasmo e da expectativa impressos no relato de Mailer sobre a Marcha, a participação de Daniel no evento - como vimos no início desse capítulo - é pouco entusiasmada e esperançosa. Daniel observa Mailer sentado nos degraus do Pentágono escutando atentamente aos alto-falantes, mas não comunga com ele do mesmo sentimento de engajamento em uma questão pungente de seu tempo. Doctorow, que foi editor e amigo de Mailer, provavelmente havia lido Armies of the Night, publicado em 1968, quando da redação do seu romance. O desencantamento de Daniel com a Marcha, o pouco espaço ocupado por esse evento na narrativa e a rápida menção ao atento Mailer revelam o enfraquecimento, trazido com o tempo e com a sequência dos eventos, da energia política registrada no relato feito no calor da hora por Mailer e ausente do romance escrito anos depois por Doctorow.

A derradeira menção à figura da estrela-do-mar traz uma explicação sobre sua origem nos signos do Zodíaco. Décimo terceiro signo do Zodíaco, desaparecido depois do ajuste egípcio do calendário caldeu no ano de 4000 a.C., a Estrela-do-mar era

\footnotetext{
284 "The March on the Pentagon was an ambiguous event whose essential value or absurdity may not be established for ten or twenty years, or indeed ever". (MAILER, op. cit, p. 53).

${ }^{285}$ Idem, p. 97.

${ }^{286}$ Idem, p. 113.
} 
considerada um dos signos mais benignos. Ela simbolizava serenidade e harmonia com o universo, a união de todos os sentimentos e a felicidade, como nos explica o narrador:

Um ascendente desse signo sugeria serenidade e harmonia com o universo e, portanto, grande felicidade. Os cinco pontos da estrela conduziam não para fora, como em geral se acredita, mas para dentro, para o centro. Isto simbolizava a união das várias faculdades mentais e a coordenação das faculdades físicas. Referiase ao casamento no âmago dos cinco sentidos. A união de todos os sentimentos. A fé unia-se ao intelecto, a linguagem à verdade e a vida à justiça. A Estrela-do-Mar em oposição a Marte significa, em geral, Gênio. Sob a influência de Vênus sugeria Paz. Por qualquer motivo, os astrólogos de hoje não a mencionam, e corre a superstição de que significa $\operatorname{azar}^{287}$. (p. 262)

O movimento de condensação de várias camadas de significação na figura da estrela-do-mar é confirmado pela própria definição dessa figura como um signo que simboliza "a união das várias faculdades mentais e a coordenação das faculdades físicas" e refere-se ao "casamento no âmago dos cinco sentidos". Nesse signo, "a fé unia-se ao intelecto, a linguagem à verdade e a vida à justiça". Nele, não há separação ou descontinuidade, ao contrário do que ocorre no mundo em que Daniel vive e de onde escreve seu livro.

O mundo pacificado sugerido no signo da Estrela-do-mar lembra o das "culturas fechadas" descrito por Georg Lukács nas primeiras linhas de sua Teoria do Romance ${ }^{288}$. A distância entre esse mundo e o mundo de Daniel é marcada, no livro, pela atual superstição que vincula o signo da Estrela-do-mar ao azar e pelo fato dos astrólogos de hoje não mencionarem mais esse signo, outrora tido como sinal de bons auspícios.

\footnotetext{
${ }^{287}$ No original: A starfish ascendant suggested serenity and harmony with the universe, and therefore great happiness. The five points of the star lead not outward as is commonly believed, but inward, toward the center. This symbolized the union of the various mental faculties and the coordination of the physical faculties. It referred to the wedding in the heart of the five senses. It implied the unification of all feelings. Belief was joined with intellect, language with truth, and life with justice. Starfish in opposition to Mars usually meant Genius. Under the influence of Venus it suggested Peace. For some reason astrologers today don't mention Starfish and there is a common superstition that it means bad luck. (p. 250).
}

288 “Afortunados os tempos para os quais o céu estrelado é o mapa dos caminhos transitáveis e a serem transitados, e cujos rumos a luz das estrelas ilumina. Tudo lhes é novo e no entanto familiar, aventuroso e no entanto próprio. O mundo é vasto, e no entanto é como a própria casa, pois o fogo que arde na alma é da mesma essência que as estrelas". (LUKÁCS, Georg. A Teoria do Romance. São Paulo: Duas Cidades, Editora 34, 2000, p. 25). 
Para a figura da estrela-do-mar, portanto, convergem: a angústia silenciosa de Susan; as tensões da Guerra Fria, evocadas na menção à bomba atômica e a toda a política externa (MAD 289 sendo sua racionalização mais paradoxal), de ambos os lados, desenvolvida a partir do domínio de sua tecnologia; o Pentágono e o que ele representava para os jovens militantes dos anos 60 .

Serenidade, harmonia e felicidade - simbolizadas pelo signo da Estrela-do-mar estão longe de caracterizar o quadro traçado pelo conjunto dos contextos entrecruzados na referência a esse signo. A solução narrativa da aproximação desses contextos pela via simbólica sugere, ao mesmo tempo, a percepção da interdependência desses fenômenos - que só se revelaria numa leitura totalizante - e a constatação da dificuldade de mapear de forma realista a trama de relações que liga esses fatos. O esforço de mapeamento sugerido nessa costura meramente simbólica de vários contextos na figura da Estrela-domar lembra o impulso de mapeamento cognitivo latente nos filmes de conspiração analisados por Fredric Jameson em seu livro The Geopolitical Aesthetic ${ }^{290}$.

O fato de tais relações serem apenas sugeridas - e não desenvolvidas em um tecido coerente - é ilustrativo da fragmentação da qual a forma desse romance é sintoma.

Paradoxalmente, a própria narrativa escrita por Daniel e o romance constituem esforços de superar essa fragmentação. É essa tentativa, e o que dela pode resultar de produtivo para o desenvolvimento de um pensamento verdadeiramente crítico, que vem ocupando a atenção aqui dada aos diversos caminhos interpretativos que esse romance abre.

\section{Daniel, narrador-pesquisador}

\footnotetext{
${ }^{289}$ Sigla em inglês para Mutual Assured Destruction, uma espécie de política de equilíbrio de forças de destruição que, ironicamente, é tida como inibidora de conflitos bélicos.

${ }^{290}$ Cf. The Geopolitical Aesthetic: Cinema and Space in the World System. London: BFI Publications, 1992. Sobretudo o capítulo "Totality as Conspiracy".
} 
O fato de o narrador do romance ter treinamento historiográfico profissional e, ao mesmo tempo, estar implicado nos fatos que analisa traz importantes consequências epistemológicas para sua investigação. A pretendida objetividade do estudo acadêmico fica ameaçada pelo envolvimento pessoal do autor, Daniel, nos fatos estudados. O narrador da própria vida é sempre um narrador não-confiável ${ }^{291}$.

Embora não esteja claro no romance o tema da tese de Daniel, é possível supor, como já vimos, que os muitos fragmentos sobre castigos corporais infligidos por uma classe a outra como elemento de controle e punição seja parte dessa tese. O tema do castigo corporal como distinção de classe é anunciado por Daniel: "Podemos dizer que a base de todas as distinções de classe na sociedade é o castigo corporal. As classes são criadas pelo castigo corporal" (p. 157). Se este for o tema de Daniel, a morte de seus pais, dissidentes executados na sádica cadeira-elétrica, fornece mais um exemplo à longa lista de tais castigos. Assim, haveria uma ligação entre a tese do historiador Daniel e o relato do filho que tenta ajudar a irmã a lidar com a injustiça cometida contra seus pais. Haveria, também, a constatação de que o que aconteceu com Paul e Rochelle nos Estados Unidos dos anos 50 foi uma atualização de uma antiga verdade: numa sociedade dividida em classes, a classe dominante precisa dispor de meios para manter seus privilégios, e a violência é um instrumento eficiente de coerção. Assim, a execução dos Isaacson - assim como a de Sacco e Vanzetti, mencionados no romance duas vezes - seria um lembrete de que a dissidência é perigosa ${ }^{292}$."

Do ponto de vista da construção ficcional, a figura do narrador pesquisador ${ }^{293}$ permite uma amplitude de reflexão sobre os diversos contextos históricos trazidos para a narrativa. Enquanto o narrador-advogado em Dom Casmurro torna possível a arguta e,

291 “... todo mundo é historiador de sua própria vida passada consciente, na medida em que elabora uma versão pessoal dela: um historiador nada confiável, sob a maioria dos pontos de vista..." (HOBSBAWN, Eric. A Era dos Impérios (1875-1914). São Paulo: Paz e Terra, 2011, p. 18).

${ }^{292}$ O personagem Tio Sam do romance de Coover lê a execução dos Rosenberg de forma semelhante: "This is to be a consecration, a new charter of the moral and social order of the Western World, the precedint on which the future is to be carn-structured to ensure peace in our time! (COOVER, op. cit., p. 91).

${ }^{293}$ Jerome de Groot ressalta a proliferação de personagens historiadores no romance histórico contemporâneo. Nessas narrativas, o historiador "é visto como alguém que busca soluções por meio da combinação de evidências e de relatos de testemunhas, mas que também precisa ser cuidadoso para não acreditar na coisa errada" (The Historical Novel. London, New York: Routledge, 2010, p. 125). 
para muitos, convincente argumentação em favor da tese da traição de Capitu, ao mesmo tempo que fornece mais um indício sobre a não-confiabilidade do relato de Bentinho, o narrador-pesquisador Daniel viabiliza uma percepção informada e historicamente consciente dos fatos narrados ao mesmo tempo que sugere a incapacidade do historiador em dar conta dos acontecimentos que integram o enredo, uma vez que, no final, nada se fecha, muito menos a tese. Durante muito tempo, leitores seguiram a narração de Bentinho convencidos de que o narrador culto e eloquente fornecia evidências suficientes para sustentar sua tese. Os leitores de Daniel seguem o narrador acompanhando suas hesitações, incertezas e erros e não aderem a verdades, já que elas não se apresentam nem para o autor da narração. Podemos dizer que a narração de Daniel, ao se mover em chão instável, não suscita um alto coeficiente de verdade.

No final dos anos 60, o romance começa a sofrer modificações importantes em sua forma. Livros como The Public Burning e The Book of Daniel são sintomáticos dessas mudanças. Há uma percepção de que o mundo já não cabe mais na forma, o que levou alguns autores, como Doctorow e Coover, a experimentos narrativos ousados, e outros, como Norman Mailer e Truman Capote, a buscar na narrativa de não-ficção uma forma de registro da realidade mais apropriada para os novos tempos. Representativo dessa segunda possibilidade é o já mencionado livro de Mailer sobre o episódio da Marcha ao Pentágono. Dividido em duas partes (History as a Novel, The Novel as History), o livro propõe uma delimitação entre história e ficção, reconhecendo também que as duas formas de organização da experiência são complementares. Sobre a diferença entre história e romance, Mailer diz:

....is finally now to be disclosed as some sort or condensation of a collective novel - which is to admit that an explanation of the mystery of the event at the Pentagon cannot be developed by the methods of history - only by the instincts of the novelist. The reasons are several, but reduce to one. Forget that the journalistic information available from both sides is so incoherent, inaccurate, contradictory, malicious, even based on error that no accurate history is conceivable. More than one historian has found a way through chains of false fact. No, the difficulty is that the history is interior - no documents can give sufficient intimation: the novel must replace history at precisely that point where experience is sufficiently emotional, spiritual, psychical, moral, existential, or supernatural to expose the fact that the historian is pursuing the 
experience would be obliged to quit the clearly demarcated limits of historic inquiry ${ }^{294}$.

John Hollowell argumenta que os romances de não-ficção surgidos na década de 60 indicam uma desconfiança no poder da narrativa ficcional de dar forma a um mundo caótico e plural em que fatos como o desenvolvimento de armas capazes de destruir o planeta várias vezes desafiam a imaginação 295 . Para Barbara Foley, "the nonfiction novel is a distinctive reaction to the surrealistic quality of a decade of urban revolt, anti-war demonstrations, and hippie counterculture; accordingly, it has a unique and characteristic form ${ }^{296}$ ".

Em estudo sobre a literatura dos anos 60, Hollowell nota um crescimento da produção e da popularidade das narrativas de não-ficção (Truman Capote, Norman Mailer e Tom Wolfe são os autores estudados por ele) e um recuo do romance. Hollowell atribui esse fenômeno à atmosfera apocalíptica dessa década na qual "talvez mais do que em qualquer outro momento da história americana, os eventos públicos eram confusos, caóticos, quase aleatórios e sem sentido ${ }^{297}$ ". Diante desse cenário, há, para Hollowell, uma busca do relato não-ficcional como fonte de testemunhos mais próximos dos fatos. No quadro de incertezas que Hollowell pinta com tintas bem sombrias, ele percebe uma timidez dos romancistas em afirmar verdades sobre o mundo, que se traduz nos romances num declínio da narração onisciente:

Novelists writing today, for example, seem less willing to make assumptions about what 'reality' is. The familiar technique of authorial omniscience has declined in recent novels, perhaps implying a reluctance to affirm the Godlike knowledge that the technique implies ${ }^{298}$.

\footnotetext{
${ }^{294}$ MAILER, op. cit., p. 255.

${ }^{295}$ HOLLOWELL, John, Fact and Fiction: The New Journalism and the Nonfiction Novel. Chapel Hill, N. C.: Univ. of North Carolina Press, 1977.

${ }^{296}$ FOLEY, Barbara. . Fact, Fiction, and "Reality". Contemporary Literature, Vol. 20, No. 3 (Summer, 1979), pp. 389-399. University of Wisconsin Press. http://www.jstor.org/stable/1208301. Acesso em: 01 de Junho de 2013.

${ }^{297}$ HOLLOWELL, John. Fact and Fiction: The New Journalism and the Nonfiction Novel. Chapel Hill, N. C.: Univ. of North Carolina Press, 1977, p. 4. Tradução minha.

${ }^{298}$ HOLLOWELL, op. cit., p. 9.
} 
O estado de desorientação que Hollowell percebe nos anos 60 ganha forma no personagem Benjamin do romance The Graduate 299 (1963). Recém graduado em História (mais um personagem historiador), Benjamin volta à casa dos pais confuso e sem saber o que fazer de sua vida: “I am confused about things. I can't tell what I'm imagining. I can't tell what's real". Ben, como é chamado no romance, parece reavaliar a realidade a sua volta com a repentina descoberta de que há algo de errado com o mundo que conhecia. Em diálogo com o pai, Ben revela esse desconforto:

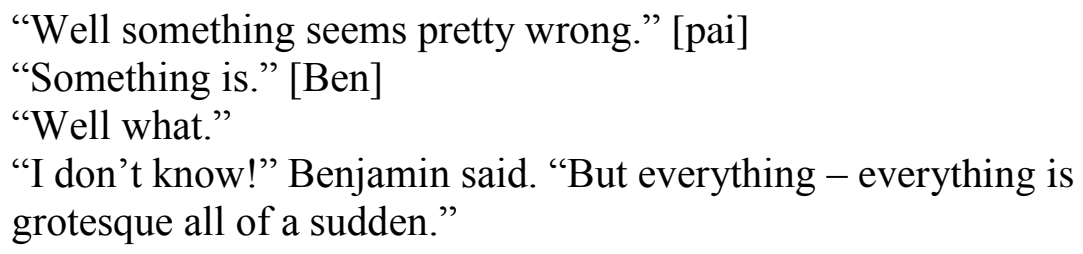

A distância entre a geração de Ben e a de seu pai aparece nesse diálogo sobre "valores":

\begin{abstract}
"Ben I - I want to talk about values. Something."
"You want to talk about values," Benjamin said. "Do you have any left?" Benjamin frowned. "Do I have any values," he said. "Values. Values." He shook his head. "I can't think of any at the moment. No."

"How can you say that, son."

"Dad, I don't see any value in anything I've ever done and I don't see any value in anything I could possibly ever do. Now I think we've exhausted the topic. How about some TV".
\end{abstract}

O caos de indecisão que toma Ben de surpresa atua também sobre o jovem Daniel. A tentativa de escrever a tese poderia ser uma forma de ceder ao impulso documentarista que Hollowell vê como dominante nos anos 60. No entanto, o passado de Daniel invade o espaço da tese, que nunca é escrita. Percebo, nessa invasão, o movimento descrito por Jameson como definidor do gênero romance histórico: a invenção de pontos de convergência entre os planos ontológicos (público/coletivo e privado/individual). Ao final da narrativa, o que Daniel nos entrega não é uma tese sobre a história da Esquerda

\footnotetext{
${ }^{299}$ WEBB, Charles. The Graduate. New York: RosettaBooks, 2011. A versão para o cinema desse romance se firmou como uma das mais eloquentes narrativas sobre os anos 60. Lançado em 1967, o filme chegou ao Brasil com o título "A Primeira Noite de um Homem".
} 
americana, mas uma vida ${ }^{300}$, verdadeiro campo de batalhas onde se cruzam vários fatos significativos do passado radical americano. Assim, por meio da experiência de Daniel, vislumbramos os conflitos e as forças que culminaram na desorientação política dos anos 60 (seja no desejo da SDS e de Susan de "mudança" por meio de uma maior participação no sistema vigente; seja na iconoclastia mais irreverente do que subversiva de Artie Sternlicht; seja no cinismo de Daniel).

\section{Daniel e a "precária síntese"}

Neste capítulo procurei oferecer uma leitura desse difícil romance que ultrapassasse as interpretação dominante dessa obra como um monumento de fragmentação ou uma proclamação, em forma de ficção, da fragilidade de afirmações de verdade sobre a História. É claro, ele traz um pouco disso, mas também esboça um certo tipo de consciência histórica ao figurar a intersecção dos planos ontológicos no cruzamento entre a vida da família Isaacson e a história política americana. Se a História é “o que fere, o que recusa o desejo e impõe limites inexoráveis ao indivíduo e à práxis coletiva $^{301}$ ", o destino de Paul, Rochelle, Susan e Daniel - marcados a fogo pelo contexto da Guerra Fria - é a figuração dessa verdade.

A intersecção entre os planos público e privado se torna clara para Daniel, já na infância, quando ele compreende, sendo o "pequeno criminoso da percepção ${ }^{302 "}$ que é, que os fatos os quais tomaram sua casa de assalto fundiram a vida da família aos conflitos

\footnotetext{
${ }^{300}$ Retomar o final do livro: "Livro de Daniel: Uma Vida Entregue em Cumprimento Parcial das Exigências do Grau de Doutorado..." (p. 317).

${ }^{301}$ JAMESON, Fredric. O Inconsciente Político - A narrativa como ato socialmente simbólico. São Paulo: Ática, 1992. p. 93.

302 Página 275 do livro em inglês.
} 
políticos da época: "Meus raciocínios procuravam ajustar minha vida e relacionamento com meu pai às palavras do jornal ${ }^{303 "} .($ p. 173)

A compreensão da história da família Isaacson passa pela compreensão da História. Inversamente, a compreensão da História é mais efetiva quando sua materialidade é percebida nos atos cotidianos de indivíduos anônimos, que são os grandes agentes históricos, embora essa constatação nem sempre é clara para esses indivíduos. Daí a ênfase de Lukács na figura do "herói mediano" como verdadeiro condutor da consciência histórica ${ }^{304}$.

As condições para a figuração desse entrelaçamento são dadas de forma mais clara em momentos de acirramento de tensões, nos quais as posições políticas e suas consequências se tornam mais evidentes e nos quais uma tomada de decisão se torna mais urgente. Em The book of Daniel vemos um mapeamento de tais momentos, por exemplo, quando o narrador estabelece uma comparação entre três momentos de conflito diferentes (Peekskill, o Macarthismo e a Marcha ao Pentágono) e ironicamente conclui, banhado de sangue, que é muito mais fácil ser um revolucionário nos anos 60 do que foi no passado. No diagnóstico de Daniel, as condições de crise que demandam ações desesperadas e inspiram o sacrifício revolucionário não estão mais dadas nos anos 60, década na qual, como já vimos, a promessa de felicidade do consumismo subornava as consciências inconformadas a se acomodar.

No entanto, Daniel produz o seu livro como um esforço hermenêutico contra a acomodação e, no limite, contra sua própria descrença. $\mathrm{O}$ trecho a seguir ilustra o desejo de compreensão de Daniel e seu conflito com as posições relativistas que começavam a se espalhar nos anos 60 com seu antiempiricismo dogmático ${ }^{305}$ :

\footnotetext{
${ }^{303}$ No original: The operations of my mind tried to conform my life and my relationship with my father to the words of the newspaper. (p. 161).

${ }^{304}$ LUKÁCS, Georges. O Romance Histórico. São Paulo: Boitempo, 2011, passim.

305 "The premise of the postmodernist position is that there is no 'reality' beyond textuality against which to measure a text's truth-value. Thus the text conducts its battles against authoritarianism and repression not primarily in its partisan representation of social conflict in its 'real-world' referent, but through its adoption of strategies of subversion in the zone of textuality itself. Ideological class struggle is displaced onto the text's conflicting rhetorical maneuvers of resistance and control, subversion and recuperation". (FOLEY, Barbara. Radical Representations - Politics and Form in U.S. Proletarian Fiction, 1929-1941.Durham, London: Duke University Press, 1993, p. 254).
} 
But this isn't the couple in the poster. That couple got away. Well funded, and supplied with false passport, they went either to New Zealand or Australia. Or Heaven. In any event, my mother and father, standing in for them, went to their deaths for crimes they did not commit. Or maybe did commit them. Or maybe my mother and father got away with false passport for crimes they didn't committ. How do you spell comit? Of one thing we are sure. Everything is elusive. God is elusive. Revolutionary morality is elusive. Justice is elusive. Human character. Quarters for the cigarette machine. You've got this two people in the poster, Daniel, now how you going to get them out? And you've got a grandma you mentioned once or twice, but we don't know anything about her. And some colored man in the basement - what is that all about? What has that got to do with anything? ? $^{306}$ (p. 42-3)

A confusão de Daniel se transfere para a própria escrita na forma de sua dificuldade em escrever o verbo "to commit", que em inglês pode tanto significar "comprometer-se, envolver-se" como "fazer algo ilegal ou considerado errado"307". Novamente, vemos a ideia de engajamento e compromisso confundida com a ideia de ação criminosa. Para o "criminoso da percepção" Daniel, essa confusão nasce com o assassinato de seus pais. Para a Esquerda americana, casos como o de Sacco e Vanzetti e o dos Rosenberg trazem a ameaçadora lembrança da criminalização de posições de esquerda na história do país. O "papel sacrificial" da esquerda nos Estados Unidos, descrito por Doctorow em ensaio mencionado no início do capítulo, parece perseguir a consciência de Daniel.

Já a afirmação de Daniel sobre a certeza do caráter ilusório de tudo ("Everything is elusive. God is elusive. Revolutionary morality is elusive. Justice is elusive. Human

\footnotetext{
${ }^{306}$ Nesse trecho, optei por dispor o texto original no corpo da tese porque a tradução omite a dificuldade do narrador em escrever a palavra "cometer" e os problemas sintáticos que mimetizam sua confusão mental. Em português: Mas não é este o casal do poster. Aquele casal escapou. Bem financiado e de posse de falsos passaportes, embarcou para a Nova Zelândia ou a Austrália. Ou o Céu. De qualquer modo, minha mãe e meu pai, assumindo o lugar deles, foram condenados à morte por crimes que não cometeram. Ou talvez tenham cometido. Talvez mamãe e papai tenham escapado com falsos passaportes por crimes que não cometeram. De uma coisa estamos certos. Tudo é fugidio. Deus é fugidio. A moral revolucionária é fugidia. A justiça é fugidia. $O$ caráter humano. Níqueis para o maço de cigarros. Há duas pessoas no cartaz, Daniel. Como pretende tirá-las dali? Você tem uma avó a quem mencionou uma ou duas vezes, mas de quem nada sabemos. E um sujeito negro no porão. Que quer dizer tudo isso? Que tem uma coisa a ver com a outra? (p. 52).
}

${ }^{307}$ http://dictionary.cambridge.org/us/dictionary/american-english/commit_3 
character.”) deve ser entendida, como várias outras de suas afirmações, de maneira irônica. O procedimento do "romance como uma sequência de análises" de que fala o narrador aparece, mais uma vez, na sequência desse trecho em que Daniel afirma a incerteza de tudo. Logo após a passagem acima reproduzida, vem o trecho sobre Peekskill, que é demarcado com título em caixa alta "PEEKSKILL". Se há algo pouco "ilusório" e muito concreto é uma multidão furiosa atirando pedras e paus e ameaçando de morte sua família. Essa é a memória de Daniel sobre esse evento histórico, do qual ele participou na companhia dos pais. Howard Fast, testumunha histórica desse episódio de ódio e intolerância, descreve a sensação que Daniel deve ter experimentado: "If you have never been in a trap with no way out and a thousand people grinning with malice and screaming in hate, you won't know what it was like 308 ". A sobreposição do trecho em que se afirma o caráter ilusório das coisas com o relato desse evento histórico que marca mais um momento na história REAL de violência e perseguição contra posições subversivas ${ }^{309}$ indica o caráter irônico da primeira afirmação.

A "sequência de análises" que Daniel tentar montar como livro é uma forma de lidar com a desorientação de sua época. Que ela resulte em um mosaico incompleto é sintomático da dificuldade da tarefa posta. A nota positiva do romance é que Daniel, ao

${ }^{308}$ FAST, Howard. PeekSkill USA - Inside the infamous 1949 riots. New York: Dover, 2006, p. 23.

${ }^{309}$ Howard Fast resume o significado político de Peekskill: "At the time of this writing it is fifteen months since the Peekskill Affair; and the onrush of events, moving with bewildering rapidity, has made of those two nights of horror isolated incidents of the past. Since then the McCarran Act has legalized the police state in America, and the creeping rot of fascism is infesting the country. Since then, the Korean war - and the immense war propaganda which accompanies it has put severe penalties upon any form of protest or dissent, and thousands of 'liberals' and 'progressives' have run for cover. At the time of Peekskill, there was almost no political prisoner in American jails; today there are a great many. At the time of Peekskill, the leaders of the Communist Party of the United States were on trial; since then they have been found guilty and the Communist Party has been placed under indictment by the McCarran Act. At the time of Peekskill, mass deportation of aliens had not yet begun nor was the concentration camp at Ellis Island in operation as it is today. At the time of Peekskill, this was not wholly a land of loyalty oaths, witch hunts, and terror for all who might hate war and love peace and democracy. And at the time of Peekskill, the plan to divide and betray the American labor movement had not yet been brought to fruition". (FAST, op. cit., p. 92). 
contrário de Benjamin, de The Graduate, transforma o seu desconforto em um grande esforço de compreensão, que testa de maneira iluminadora as possibilidades da forma em tempos de crise da representação. Mapear essas possibilidades e compreender melhor a forma possível resultante desse esforço de compreensão foi a tarefa que me propus nesse capítulo. 


\section{CAPÍTULO 2}

\section{História e figuração em Ragtime}

Apparently there wereNegroes. There wereimmigrants.

(Ragtime, p. 5).

There is no foreigner here except the capitalists.

(Big Bill Haywood, Ragtime, p. 122).

There are enough people in the streets to found an army! (Younger Brother, Ragtime, p. 292).

The oppressor is wealth, my friends. Wealth is the oppressor.

(Emma Goldman, Ragtime, p. 277). 


\section{O lugar de Ragtime nas discussões sobre os rumos do romance histórico}

Publicado em 1975, Ragtime é o livro mais conhecido e estudado de E. L. Doctorow. Vencedora de prêmios importantes, como o National Book Critics Award (1976), e recebida com entusiasmo pela imprensa ${ }^{310}$, a obra vem assumindo papel de destaque nas discussões sobre os rumos do romance histórico ${ }^{311}$ na contemporaneidade ${ }^{312}$.

O esmaecimento das fronteiras entre fato e ficção é um dos aspectos do romance mais analisado pela crítica. O declarado descompromisso do autor com a biografia de seus personagens históricos e a maneira inusitada - por vezes cômica e mesmo inverossímil - com que esses personagens interagem entre si e com criações ficcionais ${ }^{313}$

\footnotetext{
${ }^{310}$ Uma das demonstrações de entusiasmo da imprensa sobre Ragtime: "One of the best ten books of the decade!" - Times.

${ }^{311}$ Há uma grande discussão em torno do uso do termo "romance histórico". Como esse debate é longo e foge ao escopo da análise aqui proposta, usarei o termo romance histórico de maneira ampla para identificar narrativas nos quais personagens e períodos históricos específicos participam do tecido narrativo de maneira significativa. Alternativamente, usarei os termos ficção histórica e narrativa histórica com o mesmo sentido. Doctorow rejeita a classificação de romance histórico para Ragtime. Ele explica o porquê dessa rejeição: "I call Ragtime a novel. I've always found myself resisting any modification of the word novelist: historical novelist, American novelist, ethnic novelist, regional novelist. I always resist whatever word is put in front of the word novel or novelist. I automatically disagree. I set my novels very often in the past but if you think about it all novels are set in the past even those that are written about the present. The very act of writing is a delayed reaction. So whether it's the immediate past or far past it's always past. The problem is that in English the historical novel has some kind of connotation of a consumer product. Gore Vidal writes historical novels, the kind in which the novelist is essentially dealing with research and showing you what a wonderful researcher he or she is. That's not what I do in Ragtime". (MORRIS, Christopher D. (ed.) Conversations with E.L. Doctorow. Jackson: University Press of Mississippi, 1999, p. 138).
}

312 "Ragtime, published in 1975, is not only Doctorow's most popular book, it is often considered, rightly or wrongly - thanks in large part to its central place in Fredric Jameson's critique of postmodernism - the classic example of the postmodernist historical novel". (SAVVAS, Theophilus. American Postmodernist Fiction and the Past. London: Palgrave Macmillan, 2011, p. 137).

313 'I think it's very accurate but it's also a naughty book. It transgresses, it's a rebellious book, it has historical characters doing things nobody has any record for". (DOCTOROW. In: MORRIS, op. cit. p. 138) "It defies facts. Give 'em all sorts of facts - made-up facts, distorted facts. I begin 
têm motivado um debate sobre as consequências estéticas e epistemológicas do jogo entre fato e ficção nos romances que lidam com dados históricos.

Em Ragtime acontecem encontros, situações ou diálogos entre personagens históricos que nunca se deram - e dificilmente se dariam - de fato ${ }^{314}$. Vejamos alguns exemplos:

A massagem erótica de Emma Goldman em Evelyn Nesbit: sabe-se que Goldman de fato trabalhou com massagem para mulheres, como nos informa Stansell: "In 1902, at thirty-two years old, she was a virtual exile from downtown politics, living alone under an assumed name (Miss E. G. Smith) and operating a facial and massage parlor for women in the shopping district around Madison Square ${ }^{315}$ ". No entanto, o encontro entre Evelyn Nesbit (descrita pelo narrador como "the first sex goddess in American history”) e a feminista Emma Goldman ${ }^{316}$ é improvável. O passeio de Freud e Jung pelo "Túnel do Amor" em um parque de diversões: a viagem de Freud aos Estados Unidos de fato ocorreu ${ }^{317}$. O passeio com Jung no Túnel do amor é cheio de conotações e ilustrativo do modo como alguns fatos

to think of Ragtime as fictive nonfiction. It's the reverse of Truman Capote. I see all those new journalists as guys on the other side." (DOCTOROW. In: MORRIS, 1999, p. 5).

${ }^{314}$ Essa é uma característica comum a muitos romances históricos contemporâneos e que os distancia do romance histórico "clássico" do século XIX: "We are used to the idea of the historical novel, which shows famous people from the past acting in ways consistent with the verifiable public record. A common alternative is to sketch in the 'dark areas' of somebody's life, and again care is usually taken not to substantially contradict what we already know about them. In postmodernist writing, however, such contradictions are actively sought. So in Max Apple's The Propheteers (1987), the motel mogul Howard Johnson plots against Walt Disney. In Guy Davenport's Christ Preaching at the Henley Regatta (1981), Bertie Wooster and Mallarmé stand on the banks watching the boat race. In E. L. Doctorow's Ragtime (1975), Freud and Jung go through the Tunnel of Love together at Coney Island" (LEWIS, Barry. Postmodernism and Literature. In: SIM, Stuart (Editor). The Routledge Companion to Postmodernism. Routledge: New York, London, 2001, p. 132).

315 STANSELL, Christine. American Moderns - Bohemian New York and the Creation of a New Century. New York: Metropolitan Books, 2000, p. 123.

316 “...Emma Goldman, the anarchist and feminist, whose political consciousness was shaped by factory work, the Haymarket executions, the Homestead strike, the long prison term of her lover and comrade, Alexander Berkman, the depression of the 1890s, the strike struggles of New York, her own imprisonment on Blackwell's Island..." (ZINN, Howard. A People's History of the United States. New York: Harper \& Row, 1980, p. 314).

317 "Invited to lecture in the USA by Stanley Hall, President of Clark University, Freud set sail in August 1909 with Jung and Ferenczi". (APPIGNANESI, Richard; XARATE, Oscar. Introducing Freud. London: Icon Books, 2007, p. 112). 
históricos são modificados no romance para criar significados. Freud e Jung no Túnel do amor em 1909 é um comentário irônico sobre os desdobramentos da relação dos dois médicos no futuro.

> O jantar, seguido de discussão filosófica, de J. P. Morgan e Henry Ford: não há notícias de que tal encontro tenha ocorrido. No entanto, o contato entre esses dois titãs do capitalismo é rico em possibilidades de leitura econômica: ele simboliza o encontro entre a concentração econômica e o capital financeiro em ascensão (Morgan) e a "administração científica" (Ford) ${ }^{318}$. Em Ragtime, somos informados de que Morgan percebia "na realização de Ford uma ânsia de ordem tão imperiosa quanto a sua” (p. 122).

O encontro de Harry Houdini com o Arquiduque Franz Ferdinand, que congratula o mágico pela invenção do avião: além do contorno cômico trazido ao episódio pela ignorância do Arquiduque sobre a invenção do avião, esse encontro prenuncia a chegada de tempos sombrios. O leitor, sabedor dos fatos que deram origem à Primeira Guerra Mundial, percebe, com uma ciência que Houdini não poderia ter naquele momento, a iminência da catástrofe que cerca todo o enredo. Numa primeira versão desse encontro, Houdini alerta o Arqueduque sobre os acontecimentos futuros e é preso ${ }^{319}$. Apesar do episódio ter sido reescrito, sua

\footnotetext{
${ }^{318}$ Como apontam Hobsbawn e Zinn, esse encontro foi a solução do capitalismo para a crise que se agrava na época: "But even Morgan and his associates were not in complete control of such a system. In 1907, there was a panic, financial collapse, and crisis. (...) One way was Taylorism. Frederick W. Taylor had been a steel company foreman who closely analyzed every job in the mill, and worked out a system of finely detailed division of labor, increased mechanization, and piecework wage systems, to increase production and profits. In 1911, he published a book on 'scientific management' that became powerfully influential in the business world. Now management could control every detail of the worker's energy and time in the factory." (ZINN, op. cit., p. 316) / "Se o protecionismo era a reação política instintiva do produtor preocupado com a Depressão, essa não era, contudo, a reação mais significativa do capitalismo a suas dificuldades. Ela resultava da combinação de concentração econômica e racionalização empresarial ou, na terminologia americana que agora começa a definir estilos globais, 'trustes' e 'administração científica'. Ambos eram tentativas de ampliar as margens de lucro, comprimidas pela concorrência e pela queda de preços". (HOBSBAWM, Eric. A Era dos Impérios (1875-1914). São Paulo: Paz e Terra, 2011p. 77).

${ }^{319}$ Como nos conta Doctorow: "I remember very clearly a major bit of editing. It was a chapter in Ragtime in which Houdini put on his act for the Archduke Franz Ferdinand. After he flew the pane and landed, he was the invited to do a command performance in a hunting lodge in the Black Forest. Houdini did this performance and then warned the Archduke that his life was in danger, whereupon he was immediately wrestled to the floor by the Archduke's people, thrown into jail, and accused of being an anarchist. (...) I took it out because I couldn't - once that chapter was done - I couldn't then write past it. (...) it stopped me cold" (In: MORRIS, op. cit., p. 23).
} 
primeira versão demonstra a liberdade com que o autor trata os fatos históricos, chegando a imaginar a possibilidade da intrusão de elementos sobrenaturais (a clarividência de Houdini) no enredo.

$>$ O breve diálogo do jornalista e escritor Jacob Riis com o célebre arquiteto Stanford White sobre moradia para a população de imigrantes pobres de Nova York. Adiante, analisarei esse encontro.

O encontro de Houdini com Harry K. Thaw na prisão.

Em outros momentos da narrativa, no entanto, há uma busca de rigor historiográfico na descrição de detalhes sobre a época retratada. Isso ocorre, por exemplo, quando Tateh e sua filha viajam de Nova York a Boston usando bondes. No meio do parágrafo que narra a viagem somos informados de que "There was in these days of our history a highly developed system of interurban street railway lines. One could travel great distances on hard rush seats or wooden benches by taking each line to its terminus and transferring to the next ${ }^{320 "}$ (p. 91). Esse detalhe histórico sobre o sistema de transportes da época é mencionado por Doctorow em entrevista como ilustrativo do fato de que essa obra é “escrupulosamente precisa no seu propósito histórico ${ }^{321 "}$. O mesmo rigor de caracterização histórica pode ser observado nos exemplos a seguir:

The car moved through the city, its motor humming in the warm afternoon. It was a black Detroit Electric with hard rubber tires $^{322}$. (p. 41)

\footnotetext{
320 "A essa altura de nossa história existia um sistema bem desenvolvido de linhas de bondes interurbanos. Podiam-se percorrer grandes distâncias em duros bancos de veludo ou de madeira, seguindo até o fim da linha e transferindo-se para a seguinte" (p. 84).

321 "But Ragtime is scrupulously accurate in its historical intent. Furthermore, if anyone took the trouble to investigate the assertions in that book, he or she would find that a very high percentage of it is historically accurate. For example, I decided to take two of the characters on the streetcar out of New York to Lowell, Mass. I knew that there were interurban streetcar lines, but thought I'd better do some research to see that such a trip was possible. I dug up a wonderful book in the New York Public Library, a corporate history of streetcar companies, and learned, yes, you could in fact go from New York to Massachusetts by streetcar. That's an example of the way I work". (MORRIS, op. cit., p. 104).

322 "O carro atravessou a cidade, o motor pulsando no calor da tarde. Era um Detroit Electric preto, com rijas rodas de borracha" (p. 43).
} 
A car reserved for the children was attached to the end of the train. This was the Boston and Maine line. The engine was a Baldwin 4-6-0 ${ }^{323}$. (p. 126)

Later that morning in New York they made connections with an Atlantic City train in Pennsylvania Station. This was the station designed by the firm of Stanford White and Charles McKim. Its stone colonnade façades, modeled on the Roman baths at Caracalla, spanned 31st to 33rd Streets, and 7th to 8th Avenue $^{324}$. (p. 240)

No campo das avaliações estéticas, há uma tendência da crítica atual em ler o livre jogo entre fato e ficção como uma incorporação na forma do romance de questionamentos sobre a reivindicação de verdade do texto historiográfico convencional. Assim como parte da historiografia hoje se dedica ao estudo dos aspectos retóricos e narratológicos dos textos sobre história - ressaltando o caráter de discurso de toda pesquisa historiográfica - o romance, tendo incorporado essa desconfiança com afirmações de verdade sobre o passado, emprega recursos metaficcionais e a ironia para demonstrar seu caráter de construção. A noção de "metaficção historiográfica ${ }^{325 "}$ descreve bem essa tendência contemporânea do romance histórico. Nessa forma de romance histórico a intertextualidade e o livre jogo de signos são vistos como procedimentos estéticos produtivos pela possibilidade de alargar o alcance cognitivo da ficção, mantendo uma abertura para a multiplicidade de possibilidades de discursos sobre o passado:

The formal linking of history and fiction through the common denominators of intertextuality and narrativity is usually offered

\footnotetext{
323 "Um carro reservado para as crianças fora ligado ao final do trem, na linha Boston e Maine. A locomotiva era uma Baldwin 4-6-0" (p. 113).

324 "Mais tarde, durante a manhã, em Nova York, fizeram conexão com o trem de Atlantic City, na Pensilvânia Station, estação planejada pela firma de Stanford White e Charles Mckim. Suas fachadas ornadas de colunas de pedra, inspiradas nos banhos romanos de Caracalla, estendiam-se da 31st Street a 33rd Street e da Sétima à Oitava Avenidas.” (pp. 208-209).

325 Cf.: HUTCHEON, Linda. A Poetics of Postmodernism. New York: Routledge, 1988. Historiographic Metafiction: Parody and the Intertextuality of History. Disponível em <https://tspace.library.utoronto.ca/bitstream/1807/10252/1/TSpace0167.pdf> (acessado em 20/02/2012).
} 
not as a reduction, as a shrinking of the scope and value of fiction, but rather as an expansion of these ${ }^{326}$.

Há uma tendência de leitura, oposta à acima descrita, que vê o tratamento cômico e descompromissado de conteúdos históricos no romance como sintoma de um enfraquecimento da consciência histórica. No ensaio "From U.S.A. to Ragtime: Notes on the Forms of Historical Consciousness in Modern Fiction”, Barbara Foley, ao comparar a presença da História nos romances U.S.A, de John Dos Passos e Ragtime observa que entre os dois há uma diferença crucial no conceito de história que rege a tessitura da matéria romanesca ${ }^{327}$. Enquanto Dos Passos concebe a ficção como suporte da figuração da História e como algo a ela subordinada ${ }^{328}$, Doctorow valoriza a ficção como uma forma de conhecimento até superior à história ${ }^{329}$. Para o autor de Ragtime, a História não é uma força modeladora da ficção, como Dos Passos a vê $\hat{e}^{330}$, mas um depósito de imagens

\footnotetext{
${ }^{326}$ HUTCHEON, Linda. Historiographic Metafiction: Parody and the Intertextuality of History. p. 11. Disponível em <https://tspace.library.utoronto.ca/bitstream/1807/10252/1/TSpace0167.pdf> (Acesso em 20/02/2012).
}

327 Para Ickstadt, Doctorow "assumed the role of the imaginative writer as historian." (ICKSTADT, Heinz. Plotting to what end? Doctorow, Coover and the Invention (s) of History. In: MACARRO, Antonia Sanches (ed.). Studies in American Literature. Valência: Universitat de València, p. 253). Já Dos Passos se define como um "arquiteto da história", como nos explica John Wrenn: O termo 'arquiteto da história' define, pois, a intenção dupla, artística e histórica da persistente crítica de Dos Passos em relação a pessoas e fatos. Toda a sua arte é crítica, e é toda historicamente orientada. (WRENN, John H. John dos Passos. Rio de Janeiro: Editora Lidador, 1966, p. 145). Na obra de Dos Passos, o historiador se sobrepõe ao romancista: enquanto o romancista Dos Passos vai desaparecendo, o historiador vai crescendo. (WRENN, op. cit., p. 178).

328 "The story is the skeleton on which some slice of history is brought back to life. Personal adventures illustrate the development of society. Historical forces take the place of the Olympians of ancient Greek theater" (DOS PASSOS, John. What makes a novelist. In: National Review, 20, 1968.) "It seems to me that history is more alive and more interesting than fiction. I suppose that is because a story is the day-dream of a single man, while history is a mass-invention, the daydream of a race." (DOS PASSOS, John. A Great American. The New Masses, 1, dezembro de 1927).

329 "History is a kind of fiction in which we live and hope to survive, and fiction is a kind of speculative history, or a super-history, by which the available date for the composition is seen to be greater and more various in its sources than the historian supposes... There is no fiction or non-fiction as we commonly understand the distinction: there is only narrative" (DOCTOROW, E.L. False Documents. In: TRENNER, Richard. E. L. Doctorow - Essays and Conversations. Princeton, New Jersey: Ontario Review Press, 1983).

330 "I read Dos Passos when I was very young, and I admired him. I think now he was a rather sloppy writer, often sentimental, and that there is a kind of openness of form in U.S.A. - with the 
disponíveis para a criação ficcional: "I have this concept of history as imagery and therefore as a resource for writing ${ }^{331}$ ". Ragtime é a obra de Doctorow em que essa concepção da relação entre história e ficção se revela mais claramente, como o próprio autor anuncia ao ser perguntado sobre o seu foco quando está escrevendo romances: "I think it varies with the book. In Ragtime it was the historical imagery and the mockhistorical tone which most interested me $\mathrm{e}^{332}$ \%.

Barbara Foley aponta o tratamento dado aos personagens históricos no romance de Dos Passos e no de Doctorow como indicativo de diferentes visões da história. Em U.S.A., são raros os momentos em que personagens fictícios interagem com personagens históricos, os quais entram no romance em segmentos predominantemente não-ficcionais convencionalmente chamados pela crítica de "biografias". Para Foley, os segmentos biográficos de U.S.A. evidenciam a prioridade que o romancista dá à matéria histórica no processo de figurar as tensões de seu tempo ${ }^{333}$ :

If we seek a "shaped" life which recapitulates in parvo the tensions of the I.W.W., we must look to the biographies of Big Bill Haywood or Wesley Everest: not because biography is per se a more structured species of narrative discourse than fiction, but because, for the imagination informing U.S.A., history is more dynamic and coherent than fiction. Novelistic elements may enrich and broaden the scope of U.S.A., but the principal thread of unity in the narrative is history itself ${ }^{334}$.

fiction and the history separated - that does not appeal to me." (DOCTOROW. In: MORRIS, op. cit., p. 38).

${ }^{331}$ DOCTOROW. In: MORRIS, op. cit., p. 93. Essa visão é reafirmada em outras entrevistas, como, por exemplo, na passagem:"For a fiction writer, history simply is a source of imagery images. He can organize these images and arrange them within the compositions that satisfy him." (DOCTOROW. In: MORRIS, op. cit., p. 17).

${ }^{332}$ MORRIS, op. cit., p. 79.

${ }^{333}$ É importante observar aqui que Dos Passos concebe a função do romancista como a de "uma espécie de historiador de segunda classe da era em que vive (...) capaz de construir uma realidade mais fora de sua própria experiência fatual que um historiador ou biógrafo" e conclui que "qualquer romancista digno desse título é uma espécie de cão escavando ossos de que um cientista, um antropólogo ou um historiador poderão usufruir mais tarde" (WRENN, John H. John dos Passos. Rio de Janeiro: Editora Lidador, 1966, p. 149).

${ }^{334}$ FOLEY, Barbara. From U.S.A. to Ragtime: Notes on the Forms of Historical Consciousness in Modern Fiction. In: TRENNER, Richard. E. L. Doctorow - Essays and Conversations. Princeton, New Jersey: Ontario Review Press, 1983, p. 165. 
Enquanto para Dos Passos a História é "mais dinâmica e coerente que a ficção", para Doctorow a ficção, como um tipo de "super-história ${ }^{335 ", ~ p r e d o m i n a ~ c o m o ~ u m ~}$ "sistema de conhecimento 336 " mais confiável que a história. Sua confiança no poder de explicação da literatura se mostra também na ideia que ele concebe da ficção como uma "megadisciplina": "I believe so completely in fiction that I regard it as a mega-discipline, one that incorporates all other, blurs the genres, whips together fact and imagination ${ }^{337}$ ".

Barbara Foley nota essa predominância da criação ficcional sobre a História na obra de Doctorow ao analisar o personagens Coalhouse Walker $\mathrm{Jr}$ - um dos protagonistas em Ragtime - cuja criação é derivada não de fatos históricos, mas de outra ficção, o romance Michael Kohlhaas, de Heinrich von Kleist:

Doctorow's practice clearly diverges from that of Dos Passos insofar as the informing 'plot' of his novel is patently fictional. (...) The story of Coalhouse Walkers is, like the rest of Ragtime, cleverly derivative; but its source is not in historical fact but, rather, in fiction ${ }^{338}$.

Numa leitura mais próxima da noção de "metaficção historiográfica", Jesús Benito Sánchez argumenta que a não diferenciação entre fato histórico e invenção e a reescrita paródica do passado em Ragtime criam um "território de confusão ontológica" entre história e ficção como uma tentativa de "tornar a história dinâmica e em constante mudança" e de "remover o pressuposto caráter estático do passado"339. Assim, ao tratar a

\footnotetext{
${ }^{335}$ Ver nota 19.

336 "Underlying everything (...) is the writer's belief in the story as a system of knowledge. This belief is akin to the scientist's faith in the scientific method as a way to truth" (DOCTOROW, E. L. Creationists - selected essays (1993-2006). New York: Random House, 2007, p. x da introdução).
}

${ }^{337}$ DOCTOROW, E. L. Reporting the Universe. Cambridge, London: Harvard University Press, 2003 , p. 51.

${ }^{338}$ FOLEY, op. cit., p. 165-166.

339 "The novel is infused with multiple historical echoes and allusion which will be ironically subverted and contradicted. In this parodic rewriting of the past within a new context, the novel enters a territory of ontological confusion between the fiction and the historical, the past and the present, as if a willful attempt to make history dynamic and ever changing, to remove the presupposed statism of the past". (SÁNCHEZ, Jesús Benito. Doctorow's Ragtime: A Breach in the Frame of History. Atlantis: Revista de la Asociación Española de Estudios AngloNorteamericanos, ISSN 0210-6124, Vol. 19, $\mathrm{N}^{\mathrm{o}}$ 2, 1997, pp. 15-24. Disponível em 
história com irreverência e ao subordiná-la à ficção, o romance, liberto das amarras epistemológicas da disciplina acadêmica, poderia abrir novas possibilidades de leitura do passado.

Ragtime não é o único romance contemporâneo a manipular conteúdos históricos de maneira paródica e irônica ${ }^{340}$. No entanto, a maneira ostensiva como fato e ficção são manipulados e como personagens reais e fictícios interagem nesse livro fez com que ele ocupasse o centro das discussões sobre as implicações dessa nova forma de romance histórico.

A maneira como a distância entre fato e ficção é estreitada em Ragtime tem suscitado debates e é constantemente motivo de questionamentos ao autor ${ }^{341}$, que, como forma de resposta, escreveu o ensaio "False Documents" (1977), no qual afirma, entre outras coisas, que "there is no fiction or nonfiction (...): there is only narrative."Amplamente citado nas abordagens críticas sobre os romances do autor, este ensaio tem sido usado como parâmetro para sustentar argumentos sobre o caráter marcadamente "metaficcional historiográfico" de sua ficção. Dentro do espírito de polêmica que originou o ensaio, Doctorow coloca em suspensão a ideia de "fato histórico":

What is an historical fact? A spent shell? A bombed-out building? A pile of shoes? A victory parade? A long march? Once it has been suffered it maintains itself in the mind of witness or victim, and if it is to reach anyone else it is transmitted in words or on film and it becomes an image, which, with other images, constitutes a judgment ${ }^{342}$.

<http://www.atlantisjournal.org/Papers/v19\%20n2/v19\%20n2-2.pdf > acessado em 20/02/2012).

340 Em seu livro "Poética do pós-modernismo" Linda Hutcheon traz uma série de romances históricos contemporâneos, que ela classifica como "metaficções historiográficas", e descreve suas características estéticas e as tendências para esse tipo de prosa de ficção. Cf.: HUTCHEON, Linda. A Poetics of Postmodernism. New York: Routledge, 1988.

${ }^{341}$ Um exemplo do espanto de parte da crítica com esse romance pode ser visto a seguir: "What makes Ragtime especially unsettling is that it rides the line between history and fiction so adroitly that, by the novel's end, this line seems to have disappeared." (MAYNES-AMINZADE, Liz. Rescuing the Past from History: E.L.Doctorow's Ragtime. Columbia Journal of Literary Criticism - Volume IV, Spring 2006, p. 14).

${ }^{342}$ DOCTOROW. In: TRENNER, op. cit. p. 24. 
Assim o fato, sendo transmitido por palavras, ficaria sujeito a toda sorte de interpretações e mudanças de sentido. Lendo somente esses ensaios de Doctorow poderíamos concluir que o autor se filia às correntes teóricas surgidas após a "virada linguística”, a qual deu início nas Humanidades ao processo que Perry Anderson chama de "gradual megalomania do significante ${ }^{343 "}$. Encontramos uma das mais expressivas formulações desse tipo de pensamento na conhecida frase de Barthes "le fait n'a jamais qu'une existence linguistique", que não por coincidência serve de epígrafe e de mote para um importante livro de Hayden White ${ }^{344}$, expoente desse tipo de foco linguístico no pensamento historiográfico.

Em espírito irônico, perceptível no trecho que leremos a seguir, o ensaio "False Documents" termina com o dictum "ousado" de que "só há narrativa". Nas palavras do autor:

I am thus to the proposition that there is no fiction or nonfiction as we commonly understand the distinction: there is only narrative. But it is a novelist's proposition, I can see that very well. It is in my interest to claim that there is no difference between that I do and what everyone else does. I claim as I pull everyone else over to my side of the mirror that there is nothing between the given universe and your attempt to mediate it, there is no real power, only some hope that we might deny our own contingency ${ }^{345}$.

Ao ler esse ensaio, é preciso levar em consideração o fato de que Doctorow o escreve como reação às críticas de que em Ragtime as fronteiras entre fato e ficção são irresponsavelmente apagadas. Há, nesse ensaio, um certo exagero que é decorrente do desejo de polêmica e do espírito de ironia com que o autor quis vestir sua resposta à recepção negativa de Ragtime ${ }^{346}$. "False documents" também expressa a concepção do autor de que o trabalho de criação literária implica em riscos e em transgressão de

\footnotetext{
${ }^{343}$ ANDERSON, Perry. A crise da crise do marxismo. São Paulo: Brasiliense, 1985, p. 53.

${ }^{344}$ The Content of the Form - Narrative Discourse and Historical Representation. Baltimore: The Johns Hopkins University Press, 1992.

${ }^{345}$ DOCTOROW. In: TRENNER, op. cit. p. 26.

${ }^{346}$ Como declara o próprio autor: "I wrote that essay after Ragtime was published and it was an attempt to deal with critics who felt that somehow I had abused by mixing up fact and fiction. (...) I wrote it in a somewhat ironic spirit..." (In: MORRIS, op. cit., p. 131).
} 
normas $^{347}$. Tendo isso em mente, julgo prudente evitar o erro (visto em vários textos críticos sobre as obras aqui estudadas) de elevar "False documents" ao patamar de chave explicativa da obra de Doctorow ${ }^{348}$, uma vez que, como veremos nas análises dos romances, há nessa obra o predomínio de uma tensão entre a afirmação do caráter meramente discursivo dos "fatos históricos" (como é feito no ensaio) e o peso de necessidade e urgência intransigentes dos fatos, que dão materialidade à História ${ }^{349}$. Dessa forma, acredito que, apesar das ideias - que aqui destaquei - contidas nos ensaios e amplamente aceitas pela crítica, Doctorow subscreveria ${ }^{350}$ a concepção do trabalho da criação ficcional implícita nas palavras de Cristovão Tezza:

"Ser um escritor" não é uma categoria universal ou atemporal. É uma escolha bastante específica. Em contrapartida lembro-me sempre de uma frase avulsa de Roland Barthes que li no início dos anos 1970 e que agora reproduzo de memória - para o escritor, escrever é um verbo intransitivo. É uma bela imagem, ainda que eu a tenha absorvido a contragosto. Admirava Barthes como quem admira um número de prestidigitação - são apresentações mágicas, bonitas, surpreendentes, às vezes impressionantes, mas todas parecem reduzir-se a um truque. Que seja, um truque poético. Tirese a luz, o efeito da sombra, o cenário em negro, o arranjo da sintaxe, o sentido oculto na manga, o silêncio preparatório, e o poeta está nu. No fundo de tudo, grassa uma aposta sutil no irracional, num cansaço blasé das formas que, súbito, descobre a autonomia da linguagem - que ela fale sozinha. Eu não estou aqui.

347 "I believe nothing of any beauty or truth comes of a piece of writing without the author's thinking he has sinned against something - propriety, custom, faith, tradition, political orthodoxy, historical fact, literary convention, or indeed, all the prevailing community standards together. And that the work will not be realized without the liberation that comes to the writer from his feeling of having transgressed, broken the rules, played a forbidden game - without his understanding or even fearing his work as a possibly unforgiven transgression" (DOCTOROW, E. L. Reporting the Universe. Cambridge, London: Harvard University Press, 2003, p. 37).

${ }^{348}$ Um exemplo desse tipo de leitura pode ser visto na opinião de John Park sobre Ragtime: "It is a text that illustrates Doctorow's ideas of history as spelled out in the 'False Documents' essay". (PARKS, John G. The Politics of Polyphony: The Fiction of E. L. Doctorow. Twentieth Century Literature, Vol. 37, No. 4 (Winter, 1991), p. 458. Published by: Hofstra http://www.jstor.org/stable/441658).

349 “A História é o que fere, o que recusa o desejo e impõe limites inexoráveis ao indivíduo e à práxis coletiva", como nos lembra Jameson( $O$ Inconsciente Político - A narrativa como ato socialmente simbólico. São Paulo: Ática, 1992. p. 93).

350 "Literature, like history, endows places with meaning, locates them in the moral universe, gives them a charged name." (...) "... without a visible circumstance, a territory, to connect to, our spirit is shapeless, nameless, and undefined" (DOCTOROW, E. L. Jack London, Hemingway, and the Constitution: selected essays, 1977-1992. New York: Random House, 1993). 
É a linguagem que conspira, e não pessoas históricas de carne e osso $^{351}$.

A discussão em torno dos limites entre ficção e história em romances é pouco produtiva, já que o romance, sendo um gênero da esfera da criação ficcional, não pretende seguir parâmetros de verdade como o texto historiográfico se propõe a fazer. $\mathrm{O}$ fato de grande parte da fortuna crítica de Ragtime se concentrar - ou ao menos fazer referência a - essa questão diz muito do enfraquecimento daquilo que Georg Lukács definiu como "historicismo consciente", uma "clareza sobre a história como processo, sobre a história como precondição concreta do presente ${ }^{352}$, , algo que ele julgava ainda não plenamente desenvolvido no romance social inglês do século XVIII e que só atingiria sua expressão literária plena na obra de Walter Scott.

De certa forma, essa discussão sobre o caráter positivo ou negativo do tratamento deliberadamente descompromissado que obras como Ragtime dão a fatos históricos reproduz, no campo da crítica literária, o confronto de posições "empiristas" e "relativistas" que polariza o debate no campo da historiografia.

Acredito que romances como Ragtime, The Book of Daniel e Homer and Langley são animados mais por uma hermenêutica da concretude do que por uma poética da relativização e que a dificuldade da crítica em definir qual "forma de consciência histórica ${ }^{353 "}$ está figurada nesses livros é instrutiva dos impasses na definição de um conceito de história hoje.

A irreverência com que informações históricas são tratadas em Ragtime tem levado muitos críticos - apoiados, como vimos, pelas ideias sobre a relação entre fato e ficção em romances que o próprio Doctorow divulga em ensaios - a questionarem o

\footnotetext{
351 TEZZA, Cristovão. O espírito da prosa - uma autobiografia literária. Rio de Janeiro, São Paulo: Record, 2012, p. 27.

${ }^{352}$ LUKÁCS, Georges. O Romance Histórico. São Paulo: Boitempo, 2011, p. 36.

${ }^{353}$ FOLEY, op. cit.
} 
potencial político dessa obra. Mesmo críticos pouco inclinados ao estudo do caráter político da literatura acusaram Ragtime de criar uma forma literária que neutraliza qualquer possibilidade de intervenção crítica que a obra pudesse ter. Harold Bloom tranquiliza os colegas que reclamam de Ragtime por supostamente trazer uma explícita alegoria de esquerda: "Critics who complained that Ragtime was a Leftist allegory missed the point: Doctorow is not Jack London, and the comic-strip elements in Ragtime imply throughout that any political allegory is easily reversible ${ }^{354 \%}$.

O parâmetro que Bloom escolhe para absolver, nos seus termos, Ragtime do pecado de ser obra política - já que, para ele, a função da arte é criar beleza e elevar o espírito por meio da experiência estética - é o romance realista, representado na citação acima por Jack London. $\mathrm{Na}$ base dessa comparação está o procedimento, repetido em várias análises de romances históricos contemporâneos, de buscar no Romance Histórico Clássico ${ }^{355}$ um modelo para aferir a capacidade de figuração de uma obra: quando mais próximo a esse modelo, maior seria o "historicismo consciente" presente no enredo e no cruzamento do destino dos personagens com as grandes questões de seu tempo.

O livro O Romance Histórico, de Georg Lukács, permanece como exemplo de análise que lê na forma a figuração de tensões sociais presentes na sociedade. No entanto, o contexto estudado por Lukács como gerador do Romance histórico clássico está bem distante do presente. Para Lukács, esse tipo de romance oferece "un module littéraire d'un niveau très elevé pour notre description des tendences réelles de la vie populaire" ${ }^{356}$. Essa “descrição" é essencial para a compreensão da realidade histórica figurada nas obras, mas

\footnotetext{
${ }^{354}$ BLOOM, Harold. E.L. Doctorow's Ragtime. Philadelphia: Chelsea House, 2004, p. 8.

355 O Romance histórico clássico, tal como definido por Georg Lukács, tem Walter Scott, um escritor romântico, como seu maior representante, embora o idealismo romântico dessa obra seja neutralizado por "um conceito do romantismo forjado com a ajuda dos instrumentos de análise histórica marxista [que] permite a Lukács destruir a lenda corrente de um Walter Scott romântico e situá-lo no eixo do realismo" (TERTULIAN, Nicolas. Georg Lukács - Etapas de seu pensamento estético. São Paulo: Editora Unesp, 2008, p. 179). A aproximação que é feita aqui com a obra de Jack London é por via da noção de realismo em sentido amplo, aquele compromisso com o tempo histórico que caracteriza o "historicismo consciente" presente, segundo Lukács, em muitos dos romances do tempo de Scott.
}

${ }^{356}$ LUKACS, Georges. Le Roman Historique.Paris: Payot, 2000. Tradução de Robert Sailley, p. 400 . 
sua clareza está relacionada a uma constelação de eventos e forças históricas que criem condições para o "historicismo consciente"357.

Tais condições surgem na Europa pós-revolucionária (entre 1789 e 1814). O corte epistemológico trazido pela Revolução Francesa tornou o caráter histórico dos eventos mais perceptível para a população, como explicaLukács:

Ce furent la Révolution française, les guerres révolutionnaires, l'ascension et la chute de Napoléon qui firent pour la première fois de l'histoire une expérience vécue des masses, et même à l'échelle de l'Europe. Durant les décennies entre 1789 et 1814, tous les peuples d' Europe ont subi plus de bouleversements qu'ils n'en avaient éprouvés jadis en des siècles. Et la succession rapide de ces bouleversements leur donne un caractère qualitativement distinct, elle rend leur caractère historique beaucoup plus visible que d'ordinaire dans des cas isoles: les masses n'ont plus l'impression d'un "événement naturel" 358 .

Hoje, as condições para um "historicismo consciente", tais como descritas por Lukács em sua obra sobre o Romance histórico, não estão mais dadas. O que restou foi um historicismo "onipresente, onívoro e bastante próximo ao libidinal 359 ".

Muitos dos diagnósticos sobre a situação do romance histórico contemporâneo encontram no Romance histórico clássico um antípoda formal. Barbara Foley vê em Ragtime um exemplo da "alienação fundamental do autor contemporâneo em relação à história ${ }^{360}$ ". Segundo Foley, essa alienação não acontece em função do desinteresse dos autores por temas históricos e sim pelo tipo de relação que eles estabelecem com esses temas $^{361}$.

\footnotetext{
${ }^{357}$ Idem, p. 25.

${ }^{358}$ Idem, p. 21.
}

359 JAMESON, Fredric. Pós-Modernismo - A lógica Cultural do Capitalismo Tardio. São Paulo: Ática, 1996, p. 46.

${ }^{360}$ FOLEY, op. cit.

${ }^{361}$ Heinz Ickstadt oferece um diagnóstico próximo ao de Foley: "Contemporary fiction (or at least a substantial segment of it) can be said to be historical in its concern with event, yet anti-historical in its distrust of history as an ontologically sanctioned order of narration" (ICKSTADT, Heinz. Plotting to what end? Doctorow, Coover and the Invention(s) of History. In: MACARRO, Antonia Sanches (ed.). Studies in American Literature. Valência: Universitat de València. p. 251) Alcmeno Bastos, citando Lukács, destaca as diferenças entre o romance histórico contemporâneo e o clássico: "Deduz-se, portanto, que a metaficção historiográfica (ou pós-moderna), 
A discussão sobre a forma do romance em Ragtime e os diversos posicionamentos possíveis nesse debate evidenciam a força com que o problema da representação, central em nosso tempo, impõe-se na esfera da produção literária. Para Fredric Jameson, questões de representação atravessam as fronteiras entre disciplinas e vêm cada vez mais se impondo como imperativo epistemológico a todas elas. A onipresença dessas questões é tão grande hoje que a própria história vem se tornando um problema de representação. Jameson descreve o problema:

The problem of representation today eats away at all the established disciplines like a virus, particularly destabilizing the dimension of language, reference and expression (which used to be the domain of literary study), as well as that of thought (which used to be that of philosophy). Nor is economics exempt, which posits invisible entities like finance capital on the one hand, and points to untheorizable singularities like derivatives in the other. And as for political theory, the traditional question - what is the state? - has mutated into something unanswerable with its postcontemporary version, where is the state? - while the former thing called power, as solid and tangible, seemingly, as a gold coin, or at least as a dollar bill, has become the airy plaything of the mystics and physiologists alike. It is the problem of representation which has wrought all this destabilized confusion. And it can be said to be history itself which has deregulated it, so that if the dilemmas of representation are postmodern and historical, it can also be said that history as such has become a problem of representation ${ }^{362}$.

Como exposto, o lugar de Ragtime na discussão sobre a representação da história no romance contemporâneo é central tanto na conceituação de "metaficção historiográfica" para Linda Hutcheon quanto na descrição que Fredric Jameson faz da condição da consciência histórica no capitalismo tardio. Embora as posições variem, o que unifica as diversas abordagens críticas desse romance é a tentativa de definir o alcance cognitivo da forma literária - particularmente do romance histórico - hoje. A importância de Ragtime no debate sobre os rumos do romance na contemporaneidade é tão grande que um crítico chegou a sugerir que esse romance suscita uma reavaliação do próprio conceito de representação mimética: "Despite its wealth of precise images of turn-

contrariamente à 'ficção historiográfica do século XIX', não segue tal modelo de historiografia, que tomava a história como 'força modeladora', tanto da 'narrativa' quando do 'destino humano"'. (BASTOS, Alcmeno. Introdução ao romance histórico. Rio de Janeiro: EDUERJ, 2007, p. 80).

362 JAMESON, Fredric. Representing Capital. London, New York: Verso, 2011, p. 4-5. 
of-the-century America, Ragtime actually invites reexamination of the whole concept of mimetic representation ${ }^{363}$ ".

$$
* * *
$$

A forma do romance em Ragtime produz uma indeterminação epistemologicamente instrutiva porque sustenta uma tensão entre o descrédito da História como narrativa totalizante e a tentativa de figurá-la. Dessa forma, essa obra não é somente um sintoma da perda do referente histórico ${ }^{364}$, como diagnostica Jameson ${ }^{365}$, tampouco

${ }^{363}$ BEVILACQUA, Winifred Ferrant. Narration and History in E.L. Doctorow's Welcome to Hard Times, Book of Daniel and Ragtime. p. 101. Disponível em http://rauli.cbs.dk/index.php/assc/article/viewFile/1444/1457 acessado em 10/02/2012.

${ }^{364} \mathrm{O}$ professor Fabio Akcelrud Durão observou, no exame de qualificação dessa tese, como o próprio uso do termo "referente" - termo associado à linguística - em "referente histórico" é sintomático da discussão sobre a crise da historicidade, na qual o termo é usado. Em A crise da crise do marxismo (São Paulo: Brasiliense, 1985), Perry Anderson descreve o processo de "ampliação do modelo linguístico" (p. 49) para todas as disciplinas das ciências humanas. O amplo uso do termo "referente" é, acredito, resquício dessa "exorbitação da linguagem" (p. 48). Anderson explica que "o movimento de ampliação do estruturalismo é um agigantamento especulativo da linguagem que carece de qualquer título fiador" (p. 53). A seguir, um resumo dos argumentos de Anderson contra a aplicação do modelo linguístico em disciplinas como a História: 1) “...as estruturas lingüísticas, dentre as instituições sociais, têm um coeficiente excepcionalmente baixo de mobilidade histórica. Alterando-se de forma muito lenta e, com poucas e recentes exceções, inconscientemente, elas são nesse aspecto completamente opostas às estruturas econômicas, políticas ou religiosas, cujas velocidades de transformação - uma vez transposto o limiar da sociedade de classes - em geral têm sido incomparavelmente maiores". 2) “...a elocução não possui qualquer coerção material: as palavras são livres, no duplo sentido do termo. Não custam nada para serem produzidas, e podem ser multiplicadas e manipuladas à vontade, dentro das regras de sentido. Todas as outras principais práticas sociais estão sujeitas às leis da escassez natural: pessoas, bens ou poderes não podem ser gerados ad libitum e ad infinitum". 3) "...o sujeito da fala é axiomaticamente individual - 'não falem todos juntos' é a forma costumeira de se dizer que a fala plural é não-fala, que não pode ser ouvida. Em contraste, os sujeitos relevantes no domínio das estruturas econômicas, políticas, culturais ou militares são primeiro e antes de tudo coletivos: nações, classes, castas, grupos, gerações. Justamente porque é assim, a ação destes sujeitos é capaz de efetivar profundas transformações daquelas estruturas. Essa distinção fundamental é uma barreira insuperável para qualquer transposição de modelos linguísticos para processos históricos mais amplos" (p. 52). Na falta de uma opção melhor, nessa tese será usado o termo "referente histórico" no sentido que ele tem na obra de autores como Fredric Jameson e Barbara Foley.

365 “... Ragtime continua sendo o monumento mais específico e mais surpreendente à situação estética gerada pelo desaparecimento do referente histórico. Esse romance histórico não pode mais se propor a representar o passado histórico, ele pode apenas 'representar' nossas ideias e estereótipos sobre o passado (que logo se transforma, assim, em 'história pop')" (JAMESON, 
um avanço formal do romance para um tipo de autoconsciência da forma sobre as múltiplas vozes que atuam na construção do discurso historiográfico e o caráter interessado da montagem ficcional, como o lê Linda Hutcheon ${ }^{366}$.

O problema epistemológico suscitado pela forma em Ragtime transcende a mera discussão formalista sobre a classificação dessa obra como romance histórico para chegar à formulação de um impasse potencialmente produtivo sobre as formas de figuração da história no romance contemporâneo.

Para Linda Hutcheon, Ragtime encena um dos paradoxos que caracterizam todos os discursos pós-modernos:

The postmodern, then, effects two simultaneous moves. It reinstalls historical contexts as significant and even determining, but in so doing, it problematizes the entire notion of historical knowledge. This is another of the paradoxes that characterize all postmodern discourses today. And the implication is that there can be no single, essentialized, transcendent concept of "genuine historicity" (as Fredric Jameson desires), no matter what the nostalgia (Marxist or traditionalist) for such an entity. Postmodern historicism is willfully unencumbered by nostalgia in its critical, dialogical reviewing of the forms, contexts, and values of the past ${ }^{367}$.

No trecho acima, Hutcheon toma um sintoma (o duplo movimento dos artefatos pós-modernos de buscar a história ao mesmo tempo em que negam qualquer noção de conhecimento histórico) como determinação para concluir que "there can be no single, essentialized, transcendent concept of 'genuine historicity"'. O que para Jameson é um sintoma da "condição pós-moderna ${ }^{368 "}$ - a saber, a perda do referente histórico e a consequente crise da representação - para Hutcheon é apenas "nostalgia (Marxista ou tradicionalista)".

Ragtime é mencionado por Hutcheon como exemplo de narrativa contemporânea que ilustra as características do "historicismo pós-moderno". Para a teórica canadense, a

Fredric. Pós-Modernismo - A lógica Cultural do Capitalismo Tardio. São Paulo: Ática, 1996, p. $52)$.

\footnotetext{
${ }^{366}$ A Poetics of Postmodernism. New York: Routledge, 1988, p. 89.

${ }^{367}$ HUTCHEON, op. cit., p. 89.

${ }^{368}$ Termo de David Harvey.
} 
leitura de Jameson - que, como visto acima, entende esse romance como um "monumento à situação estética engendrada pelo desaparecimento do referente histórico" - pode ser facilmente revertida para uma leitura que encontra no romance justamente o contrário: a história em destaque. No centro do confronto entre essas duas posições está a noção de referente histórico, que para Linda Hutcheon se limita à "evocação precisa de um período específico do capitalismo americano do início do século $\mathrm{XX}^{369}$ " e à aparição de personagens históricos na ficção.

Ainda que o equívoco da leitura de Hutcheon se dê pela estreiteza de sua noção de referente histórico, o que me interessa aqui é o fato de que a forma do romance em Ragtime sustenta uma dificuldade epistemológica a qual tem confundido a crítica e suscitado leituras diversas, que participam de uma discussão de grande interesse sobre a representação da história no romance contemporâneo.

A mistura de história e ficção, um dos temas mais lembrados e disputados pelos comentadores de Ragtime, como vimos, também divide as leituras de Jameson e Hutcheon, para quem a mistura do histórico e do fictício é o grande trunfo da "metaficção historiográfica" para tornar o leitor consciente da natureza específica do referente histórico:

Of course, it is this mixing of the historical and the fictive and this tampering with the 'facts' of received history that Jameson objects to. Yet that is the major means to making the reader aware of the particular nature of the historical referent ${ }^{370 "}$.

Aqui, novamente, a distância entre as duas leituras se deve às diferentes concepções da história que orientam os dois $\operatorname{críticos}^{371}$.

\footnotetext{
${ }^{369}$ HUTCHEON, op. cit, p. 89.

${ }^{370}$ HUTCHEON, op. cit, p. 89.

${ }^{371}$ A concepção da história como discurso que orienta Hutcheon pode ser percebida nesse trecho: "To speak of provisionality and indeterminacy is not to deny historical knowledge, however. This is the misunderstanding suggested by Gerald Graff when he laments: "For if history is seen as an unintelligible flux of phenomena, lacking in inherent significance and structure, then no exertions of the shaping, ordering imagination can be anything but a dishonest refuge from truth" (1973, 403). What the postmodern writing of both history and literature has taught us is that both history and fiction are discourses, that both constitute systems of signification by which we make sense of the past ("exertions of the shaping, ordering imagination"). In other words, the meaning and shape are not in the events, but in the systems which make those past "events" into present
} 
O jogo entre fatos históricos e ficção está presente em grande parte da obra de Doctorow, mas em nenhum dos seus livros esse jogo é em si um dado formal tão importante quanto em Ragtime. Em The Book of Daniel, por exemplo, há questões sobre as diferenças entre a família Isaacson e seus pares históricos, os Rosenberg, bem como sobre outros dados do julgamento desses supostos espiões atômicos. No entanto, as modificações dos fatos históricos nesse romance não trazem grandes implicações para a construção do leitmotiv do romance, a saber, a história da esquerda americana no século XX. Além disso, há nessa obra a intrusão de um certo "modo documentário", presente em diversas partes do romance e respaldado narrativamente pela informação de que o livro de Daniel é escrito enquanto o narrador elabora sua tese de doutorado na biblioteca da Universidade de Colúmbia. O recurso narrativo da mistura de tese e escrita biográfica que define a narração de Daniel no romance permite um trânsito mais verossímil entre um modo narrativo ficcional e um modo documentário.

O exercício, praticado por alguns críticos de Ragtime e muito solicitado ao seu autor em entrevistas, de definir nos episódios contidos na obra os limites entre o fato histórico verificável e a mera ficção não abre grandes possibilidades de entendimento da presença da História nesse romance histórico. Nas páginas que se seguem iremos estudar algumas formas com que o externo (a História) se torna interno (a forma do romance) em Ragtime ${ }^{372}$.

Sendo este o norte do presente trabalho, não cabe aqui nenhuma tentativa de inventar uma definição de romance histórico que possa abrigar Ragtime. Em vez disso, tratarei de entender os modos pelos quais Ragtime dá forma a um impulso de figurar a história ou, em maior medida, à necessidade de dar sentido à experiência histórica. Assim, mesmo as falhas de figuração do romance podem ser úteis em um esforço de representação mais amplo ${ }^{373}$.

historical "facts". This is not a "dishonest refuge from truth" but an acknowledgement of the meaningmaking function of human constructs" (idem, p. 89).

${ }^{372}$ Lembrando a lição de Antônio Cândido, quando o externo se torna interno "a crítica deixa de ser sociológica, para ser apenas crítica. $\mathrm{O}$ elemento social se torna um dos muitos que interferem na economia do livro, ao lado dos psicológicos, religiosos, linguísticos e outros. Neste nível de análise, em que a estrutura constitui o ponto de referência, as divisões pouco importam, pois tudo se transforma, para o crítico, em fermento orgânico de que resultou a diversidade coesa do todo." (CÂNDIDO, Antônio. Literatura e Sociedade. Rio de Janeiro: Ouro sobre Azul, 2006, p. 16.).

${ }^{373}$ Para lidar com um objeto de representação difícil como Ragtime e integrar a leitura de suas lacunas e indefinições numa compreensão mais ampla do problema da representação hoje, tomo 
Romances como Ragtime provam, a meu ver, que a história como um processo sujeito à vontade humana ainda mobiliza a imaginação criadora. A vontade de entender esse processo e inventar formas de participação do homem nos grandes movimentos da História é um impulso latente nessas obras de ficção histórica. O otimismo dessa afirmação não é solitário. Em recente e importante intervenção no debate sobre a atualidade do romance histórico, Fredric Jameson encerra sua fala com notas de esperança sobre o potencial de consciência histórica que esses romances podem ainda preservar. Jameson acredita que, mesmo no horizonte sombrio das teses fatalistas (do fim da história, da política, da arte, da ideologia etc...), novas formas do romance histórico surgirão, trazendo vigor ao pensamento sobre história e abrindo caminho para formas de consciência histórica:

Contudo, podemos estar certos de que, por mais longo que seja o curso percorrido, o nosso tempo não é nem o do fim da história, nem o do fim da política e nem mesmo o do fim da arte, e de que no que toca ao romance histórico a necessidade irá produzir mais invenção, de modo que insuspeitadas novas formas do gênero inevitavelmente irão abrir seus caminhos ${ }^{374}$.

\section{O jogo entre fato e ficção}

como exemplo o esforço de Jameson para entender a dialética da representação no Capital, de Marx. Os problemas enfrentados por Marx na construção de um modelo que representasse o capitalismo ainda ecoam nas tentativas de se esboçar alguma visão da totalidade hoje, como Jameson aponta: "every attempt to construct a model of capitalism - for this is now what representation means in this context - will be a mixture of success and failure: some features will be foreground, others neglected or even misrepresented. Every representation is partial, and I would also stress the fact that every possible representation is a combination of diverse and heterogeneous modes of construction or expression, wholly different types of articulation that cannot but, incommensurable with each other, remain a mixture of approaches that signals the multiple perspectives from which one must approach such a totality and none of which exhaust it. (...) Yet the conclusion to draw here is not that, since it is unrepresentable, capitalism is ineffable and a kind of mystery beyond language or thought; but rather that one must redouble one's efforts to express the inexpressible in this respect. Marx's book gives us the supreme example of a dialectical effort to do so, and this is why the way in which he finally did represent it is so significant and urgent for us today" (JAMESON, Fredric. Representing Capital. London, New York: Verso, 2011, p. 6-7).

374 JAMESON, Fredric. O Romance Histórico ainda é possível? Revista Novos Estudos CEBRAP, número 77, 77, março de 2007, pp. 185-203. 
Como vimos, Ragtime representa, para muitos de seus leitores críticos, a situação estética gerada pelo desaparecimento do referente histórico. Jameson chega a propor que esse romance já não pode representar o passado histórico e, na tentativa de fazê-lo, só consegue explicitar nossas ideias e estereótipos do passado e construir uma versão pop da história $^{375}$. Na leitura de Jameson, Ragtime estaria envolto em uma espécie de aporia da representação, uma vez que seu grande tema - a representação da História e sua crise deve ser elaborado por meio da própria lógica cultural que dialeticamente é fruto e origem dessas mesmas dificuldades de representação:

O que é culturalmente interessante, no entanto, é que ele [Doctorow] teve de veicular esse grande tema formalmente (uma vez que o esmaecimento do conteúdo é precisamente seu assunto) e, mais do que isso, elaborar sua obra através da própria lógica do pós-moderno, que é, em si mesma, a marca e o sintoma de seu dilema $^{376}$.

Nesse sentido, em termos de representação Ragtime enfrentaria, para Jameson, uma situação semelhante a do Barão de Munchausen, personagem que tenta escapar da areia movediça puxando os próprios cabelos ${ }^{377}$.

Acredito que o diagnóstico pessimista de Jameson sobre o romance deva ser entendido dentro do contexto em que foi exposto: o grande panorama da "lógica cultural" do capitalismo tardio que é seu livro mais conhecido. Dentro desse panorama, os romances de Doctorow aparecem no momento em que Jameson fala da crise da historicidade e da adoção, na arquitetura, de procedimentos de citação que transformam estilos antigos em pastiche, canibalizando os estilos arquitetônicos do passado e os combinando em conjuntos estimulantes ${ }^{378}$.

\footnotetext{
${ }^{375}$ JAMESON, Fredric. Pós-Modernismo - A lógica Cultural do Capitalismo Tardio. São Paulo: Ática, 1996, p. 52.

${ }^{376}$ JAMESON, op. cit., p. 51.

${ }^{377}$ LOWY, Michel. As aventuras de Karl Marx contra o Barão de Munchhhausen: marxismo e positivismo na sociologia do conhecimento. São Paulo: Cortez, 1994.

${ }^{378}$ JAMESON, op. cit., p. 46.
} 
Seguindo a constituição desse quadro de crise da representação histórica, Jameson trata dos "filmes de nostalgia 379 ", os quais abordam o passado por meio de "conotações estilísticas $^{380 ",}$, imagens e clichês visuais da época retratada. O efeito dessa evocação do passado por meio do que se tem como o estilo de cada época é o deslocamento da história real, como explica Jameson: "a história dos estilos estéticos desloca a história 'real" 381 ",

Os romances de Doctorow entram nesse cenário como objetos de estudo privilegiados dos fenômenos descritos por Jameson:

No que diz respeito à "histórica real" - o objeto tradicional, como quer que se defina, do que costumava ser o romance histórico - , é mais revelador voltarmo-nos agora para essa forma e meio mais antigos e ler sua sorte pós-moderna na obra de um dos poucos romancistas de esquerda talentosos e inovadores dos Estados Unidos hoje ${ }^{382}$.

O estudo que proponho aqui procura mostrar que a leitura de Jameson é correta quando descreve as maneiras como a crise da historicidade se inscreve nos romances de Doctorow, porém radicalmente pessimista no que diz respeito ao alcance cognitivo desses romances.

Se é verdade que, por vezes, o romance evoca o passado por meio de procedimentos de acúmulo de imagens e clichês que remetem, através do estilo, à época mencionada, o exagero da paródia denuncia e anula o potencial conteúdo de nostalgia desse procedimento estético. Se o estilo paratático da linguagem em Ragtime, com suas frases curtas e períodos coordenados, parece privilegiar a não-continuidade, a justaposição e a sintaxe cumulativa criam relações iluminadoras e reestabelecem a causalidade perdida no isolamento sintático no nível do período. Se é verdade, como sugere Bárbara Foley, que o tratamento cômico dos personagens históricos e o caráter anedótico de algumas de suas ações no romance colocam em suspensão a historicidade da construção romanesca, também podemos perceber encontros inventados que

\footnotetext{
${ }^{379}$ Idem.

${ }^{380}$ Idem, p. 47.

${ }^{381}$ Idem.

${ }^{382}$ Idem, p. 48.
} 
constituem verdadeiras colisões iluminadoras de tendências históricas. É essa tensão entre sintomas da crise e soluções formais iluminadoras que define, para mim, a forma do romance em Ragtime, como veremos nas páginas a seguir.

O jogo entre fato e ficção em Ragtime não é um mero exercício de criação com propósito cômico. Embora o tom pretendido para o romance seja o de uma "imitação cômica de tom histórico" (tópico que será discutido adiante), há sempre uma intenção de sugerir relações por trás dos encontros entre os personagens históricos. Essa intenção é clara se pensarmos no grande número de encontros improváveis entre indivíduos que representam posições políticas opostas, como é o caso de Jacob Riis e Stanford White.

Riis, um imigrante que viveu nas áreas pobres de Nova York tempo suficiente para formar uma consciência da divisão da cidade como uma divisão baseada em classes sociais, ficou conhecido por seu livro How the other half lives (1890), cujas linhas iniciais já anunciam a tensão social crescente entre os imigrantes pobres na virada do século, tensão presente também no enredo de Ragtime:

Long ago it was said that "one half of the world does not know how the other half lives". That was true then. It did not know because it did not care. The half that was on top cared little for the struggles, and less for the fate of those who were underneath, so long as it was able to hold them there and keep its own seat. There came a time when the discomfort and crowding below were so great, and the consequent upheavals so violent, that it was no longer an easy thing to do, and then the upper half fell to inquiring what was the matter. Information on the subject has been accumulating rapidly since, and the whole world has had its hands full answering for its old ignorance ${ }^{383}$.

Stanford White foi um dos arquitetos mais conhecidos de seu tempo. O Madison Square Garden é uma de suas mais famosos criações. Ao contrário de Riis, o mundo de White é o dos salões da grande burguesia nova-iorquina. $\mathrm{O}$ encontro de Riis e White é

\footnotetext{
${ }^{383}$ RIIS, Jacob. How the other half lives - studies among the tenements of New York. New York: Penguin Books, 1997, p. 5.
} 
improvável em termos históricos, mas no romance ele existe como um prenúncio das tensões que se intensificarão ao longo da narrativa. Riis deseja entrevistar o grande arquiteto para saber se ele já projetara moradias para famílias pobres. Riis quer conhecer as ideias de White sobre moradia pública, poços de ventilação, iluminação. White ignora a presença de Riis, pois sua atenção está toda voltada para os ricos ornamentos europeus que ele encomendara para seus projetos arquitetônicos:

Whole facades of Florentine palaces and Athenian atria, stone by marked stone; paintings, statuary, tapestries, carved and painted ceilings in crates, tiled patios, marble fountains, marble stairs and balustrades, parqueted floors and silk wall panels; cannon, pennants, suits of armor, crossbows and other ancient weaponry; beds, armoires, chases, refectory tables, sideboards, harpsichords; barrels of glassware, silver, goldplate, porcelain and china; boxes of church ornaments, boxes of rare books, snuffboxes ${ }^{384}$. (p. 18)

Mais adiante, tratarei da linguagem usada no romance. Aqui, no entanto, cabe informar que há várias passagens do livro que trazem listas como a acima. Elas trazem, pelo excesso, ênfase para os itens listados e a atenção do leitor para o absurdo do excesso retratado. Chamarei esse procedimento de expressão de "sintaxe cumulativa".

O contraste entre a riqueza de uma pequena parcela da população - evocada nos itens da lista acima - e a miséria com que os imigrantes pobres da cidade convivem está presente, por exemplo, nessa passagem da narrativa, na qual Tateh, um imigrante judeu que vive com a mulher e a filha no Lower East Side, decide levar a família para conhecer a parte alta da ilha de Manhathan:

One Sunday, in a wild impractical mood, they spent twelve cents for three fares on the streetcar and rode uptown. They walked on Madison Avenue and Fifth Avenue and looked at the mansions. Their owner called them palaces. And that's what they were, they were palaces. They had all been designed by Stanford White. Tateh

\footnotetext{
${ }^{384}$ As páginas indicadas ao lado dos trechos do original e da tradução são das versões em inglês e português que constam da bibliografia. Nesse capítulo, optei por colocar o texto original no corpo e as traduções em nota, por facilitar a exposição, já que tratarei de questões de estilo e linguagem no romance que ficam mais evidentes no original. "Fachadas inteiras de palácios florentinos, átrios atenienses, marcados pedra por pedra; quadros, estatuária, tapeçaria, tetos esculpidos e pintados acondicionados em caixotes, pátios lajeados, fontes de mármore, escadarias e balaustradas, assoalhos de parquet e painéis de parede revestidos de seda; canhões, flâmulas, armaduras, bestas e outras armas antigas; camas, armários, divãs, mesas de refeitório, bufês, harpas; barricas cheias de cristais, prataria, baixelas de ouro, porcelana e louça; caixa de ornamentos de igreja, livros raros, caixinhas de rapé”. (p. 24).
} 
was a socialist. He looked at the palaces and his heart was outraged. The family walked quickly. The police in their tall helmets looked at them. On these wide empty sidewalks in this part of the city the police did not like to see immigrants ${ }^{385}$. (p. 15)

Os procedimentos da sintaxe cumulativa e da justaposição de contextos opostos, recorrentes no romance, mostram sua força de expressão novamente no trecho abaixo, no qual o luxo e a riqueza da sociedade que Stanford White representa é colocada lado a lado com o quadro de miséria da parte da cidade tão bem conhecida por Riis, o grande cronista da vida nos tenements nova-iorquinos:

That evening White went to the opening night of Mamzelle Champagne at the roof garden at Madison Square. This was early in the month of June and by the end of the month a serious heat wave had begun to kill infants all over the slums. The tenements glowed like furnaces and the tenants had no water to drink. The sink at the bottom of the stairs was dry. Fathers raced through the streets looking for ice. Tammany Hall had been destroyed by reformers but the hustlers on the ward still cornered the ice supply and sold little chips of it at exorbitant prices. Pillows were placed on the sidewalks. Families slept on stoops and in doorways. Horses collapsed and died in the streets. The Department of Sanitation sent drays around the city to drag away horses that had died. But it was not an efficient service. Horses exploded in the heat. Their exposed intestines heaved with rats. And up though the slum alleys, through the gray clothes hanging listlessly on lines strung across air shafts, rose the smell of fried fish ${ }^{386}$. (pp. 18-19)

\footnotetext{
385 "Certo domingo, num rompante, gastaram 12 centavos em três passagens de bonde e seguiram para além do centro da cidade, caminhando pela Madison e Quinta Avenida, admirando as mansões. Os proprietários chamavam-nas de palácios. E eram exatamente isso - palácios. Haviam sido todos planejados por Stanford White. Tateh era socialista. Olhando-os, sentiu-se intimamente ultrajado. A família caminhava depressa. Os policiais, com seus altos capacetes, observavam-nos. Nas amplas e vazias calçadas daquele lado da cidade, a polícia não gostava de ver imigrantes". (pp. 21-22).
}

386 "Naquela noite, White compareceu à estréia de Mamzelle Champagne, no terraço do Madison Square. Estava-se em princípios de junho e no final do mês anterior uma forte onda de calor começara a matar bebês em todos os cortiços. As construções brilhavam como fornalhas e seus habitantes não dispunham de água para beber. O tanque no fundo da escadaria estava seco. Pais corriam as ruas em busca de gelo. Tammany Hall fora destruído pelos reformadores, mas os exploradores continuavam a monopolizar o gelo e a vender lascas a preços exorbitantes. Travesseiros eram colocados nas calçadas. Famílias dormiam em patamares e portas. Cavalos tombavam e morriam nas ruas. O Departamento Sanitário enviava carroças pela cidade para arrastar os animais que haviam morrido, mas o serviço não era eficiente. Cavalos explodiam devido ao calor. Os intestinos expostos fervilhavam de ratos. E nos becos dos bairros miseráveis, 
Uma passagem do livro de Riis é incorporada pelo narrador como parte da narrativa. Não havendo indicação sobre o livro que a inspirou, essa passagem é incorporada ao romance como se tivesse ali surgido, só sendo possível identificar sua origem com a leitura de How the other half lives. A passagem é disposta como parte da narração - sem indicação bibliográfica - como forma de mostrar que o contexto social recriado no romance é o mesmo descrito por Riis. Nela, as frases que Riis usa em seu livro aparecem como falas do personagem reportadas pelo narrador. Assim, o parágrafo de How the other half lives é ligeiramente modificado e se integra sem dificuldades à narrativa de Ragtime. Vejamos a comparação entre a passagem do romance e o original de Riis:

\begin{tabular}{|c|c|}
\hline RAGTIME & HOW THE OTHER HALF LIVES \\
\hline $\begin{array}{l}\text { Riis made color maps of Manhattan's } \\
\text { ethnic populations. Dull gray was for Jews } \\
\text { - their favorite color, he said. Red was } \\
\text { for the swarthy Italian. Blur for the thrifty } \\
\text { German. Black for the African. Green for } \\
\text { the Irishman. And yellow for the cat-clean } \\
\text { Chinaman, a cat also in his traits of cruel } \\
\text { cunning and savage fury when aroused. } \\
\text { Add dashes of color for Finns, Arabs, } \\
\text { Greeks, and so on, and you have a crazy } \\
\text { quilt, Riis cried, a crazy quilt of } \\
\text { humanity! }{ }^{387} \text { (p. 17) }\end{array}$ & $\begin{array}{l}\text { A map of the city, colored to designate } \\
\text { nationalities, would show more stripes } \\
\text { than on the skin of a zebra, and more } \\
\text { colors than any rainbow. The city on such } \\
\text { a map would fall into two great halves, } \\
\text { green for the Irish prevailing in the West } \\
\text { Side tenement districts, and blue for the } \\
\text { Germans on the East Side. But } \\
\text { intermingled with these ground colors } \\
\text { would be an odd variety of tints that would } \\
\text { give the whole the appearance of an } \\
\text { extraordinary crazy-quilt. (...) Between } \\
\text { the dull gray of the Jew, his favorite color, } \\
\text { and the Italian red, would be seen } \\
\text { squeezed in on the map a sharp streak of } \\
\text { yellow, marking the narrow boundaries of } \\
\text { Chinatown. Dovetailed in with the } \\
\text { German population, the poor but thrifty } \\
\text { Bohemian might be picked out by the } \\
\text { sombre hue of his life as of his philosophy, }\end{array}$ \\
\hline
\end{tabular}

por sobre as roupas cinzentas que pendiam imóveis de cordas presas nos poços de ventilação, flutuava o cheiro de peixe frito". (pp. 24-25).

387 "Riis desenhou mapas coloridos da população étnica de Manhattan. Cinza opaco para os judeus, sua cor predileta, dizia. Vermelho para os italianos morenos. Azul para os frugais alemães. Verde para os irlandeses. Negro para os africanos. E amarelo para os chineses, limpos como os gatos, felinos também nos traços de cruel ambição e fúria selvagem, quando despertos. E, acrescentando-se manchas coloridas para os finlandeses, os árabes, os gregos, etc., obtinha-se uma colcha doida de retalhos, gritava Riis, uma colcha doida de humanidade!” (p. 23). 


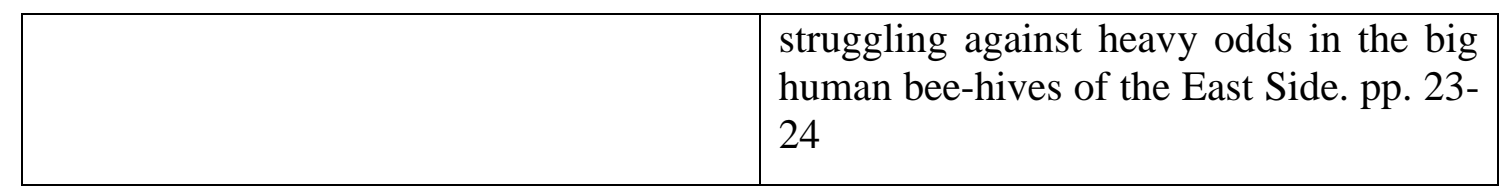

O jogo entre fato e ficção em Ragtime não deve ser analisado em função do maior ou menor grau de rigor historiográfico com que os dados da história são tratados. Como venho mostrando, o tratamento descompromissado com critérios de veracidade dado à matéria histórica nesse romance não é um sinal dos tempos do fim da consciência histórica; também não é somente um jogo metaficcional para lembrar o leitor do caráter discursivo de toda construção historiográfica. É, sim, um jeito de sugerir relações de forma a iluminar tendências que a mera exposição dos fatos históricos talvez não fosse capaz de iluminar. Assim, mesmo que o encontro de Riis e White não tenha acontecido historicamente, seu encontro no romance promove um choque de mundos que permeará toda a narrativa na forma de uma dialética da riqueza e da exclusão.

Da mesma forma, a breve presença de Sigmund Freud no enredo pode parecer apenas anedótica, dado o tratamento cômico que o episódio recebe. A passagem de Freud por Ragtime começa com um comentário casual sobre sua viagem à América intercalada à descrição da relação de Houdini com a mãe:

He was a Jew. His real name was Erich Weiss. He was passionately in love with his ancient mother whom he had installed in his brownstone home on West 113th Street. In fact Sigmund Freud had just arrived in America to give a series of lectures at Clark University in Worcester, Massachusetts, and so Houdini was destined to be, with Al Jolson, the last of the great shameless mother lovers, a nineteenth-century movement that included such men as Poe, John Brown, Lincoln and James McNeill Whistler ${ }^{388}$. (p. 36)

A partir daí, o foco da narração passa de Houdini para Freud. Somos informados do itinerário turístico de Freud e seus discípulos: jantar no Hammerstein’s Roof Garden, onde o grupo acompanha uma interpretação no violino da Rapsódia Húngara, de Franz

\footnotetext{
388 "Era judeu. Seu verdadeiro nome era Erich Weiss. Era apaixonado pela velha mãe, a quem instalara em sua casa de pedra da West 113th Street. Na verdade, Sigmund Freud acabava de chegar à América para fazer uma série de conferências na Universidade Clark, em Worcester, Massachusetts, de modo que Houdini destinava-se a ser, com Al Jolson, livre de vergonha, o último dos grandes amantes da própria mãe, movimento do século XIX que incluiu homens como Poe, John Brown, Lincoln e James McNeill Whistler". (p. 37).
} 
Liszt e Freud come "cup custard"; visitas ao Central Park, Metropolitan Museum, Chinatown; sessão de cinema mudo... todo o itinerário habitual de um simples turista, com alguns momentos cômicos: como a urgência de Freud em ir ao banheiro - que obriga o grupo todo a entrar em um restaurante e pedir comida - seguido de comentário do psicanalista sobre a ausência de sanitários públicos em Nova York e o desagrado de Freud com um atendente nas Cataratas do Niágara que pede para o grupo deixar o velhinho ir na frente.

Em visita ao Lower East Side, o grupo cruza com Tateh, sua filha e Evelyn Nesbit. Não há consequências narrativas imediatas resultantes desse encontro, nem do episódio da passagem de Freud pela América. A presença desse personagem histórico no romance se limita às poucas páginas dedicadas à sua visita aos Estados Unidos e às suas impressões desse país. O episódio seria um simples interlúdio cômico não fosse o comentário com que Freud se despede do enredo de Ragtime: “America is a mistake, a gigantic mistake". A afirmação de Freud é seguida de um relato da divisão de classes nos Estados Unidos que, aparecendo imediatamente após a frase, soa como um desenvolvimento do comentário do médico austríaco, como sugere a primeira sentença do parágrafo:

At the time of course not a few people on those sores were ready to agree with him. Millions of men were out of work. Those fortunate enough to have jobs were dared to form unions. Courts enjoined them, police busted their heads, their leaders were jailed and new men took their jobs. A union was an affront to God. The laboring man would be protected and cared for not by the labor agitators, said one wealthy man, but by the Christian men to whom God in His infinite wisdom had given the control of the property interests of this country. If all else failed the troops were called out. Armories rose in every city of the country. In the coal fields a miner made a dollar sixty a day if he could dig three tons. He lived in the company's shacks and bought his food from the company stores. On the tobacco farms Negroes stripped tobacco leaves thirteen hours a day and earned six cents an hour, man, woman or child. Children suffered no discriminatory treatment. They did not complain as adults tended to do. Employers liked to think of them as happy elves. If there was a problem about employing children it had to do only with their endurance. They were more agile than adults but they tended in the latter hours of the day to lose a degree of efficiency. In the canneries and mills these were the hours they were most likely to lose their fingers or have their hands mangled or their legs crushed; they had to be counseled to stay alert. In the mines they worked as sorters of coal and sometimes were smothered in the coal chutes; they were warned to keep their wits about them. One hundred Negroes a 
year were lynched. One hundred miners were burned alive. One hundred children were mutilated. There seemed to be quotas for these things. There seemed to be quotas for death by starvation. There were oil trusts and banking trusts and railroad trusts and beef trusts and steel trusts. It became fashionable to honor the poor. At palaces in New York and Chicago people gave poverty balls. Guests came dressed in rags and ate from tin plates and drank from chipped mugs. Ballrooms were decorated to look like mines with beams, iron tracks and miner's lamp. Theatrical scenery firms were hired to make outdoor gardens look like dirt farms and ding rooms like cotton mills. Guests smoke cigar butts offered to them on silver trays. Minstrels performed in blackface. One hostess invited everyone to a stockyard ball. Guests were wrapped in long aprons and their heads covered with white caps. They dined and danced while hanging carcasses of bloody beef trailed around the walls on moving pulleys. Entrails spilled on the floor. The proceeds were for charity ${ }^{389}$. (pp. 39-40)

\footnotetext{
389 "Na época, muita gente por estas plagas estaria disposta a concordar com ele. Havia milhões de homens desempregados. Os que tinham a sorte de ter um emprego ousavam organizar sindicatos. Tribunais impunham-lhes proibições, a polícia agredia-os, os líderes eram presos e substituídos nos seus empregos. Um sindicato era uma afronta a Deus. O operário não seria protegido e atendido por agitadores das massas, declarou um homem rico, mas por cristãos a quem Deus, em Sua infinita sabedoria, entregara o controle da propriedade e os interesses do país. Se tudo o mais falhasse, as tropas seriam convocadas. Fábricas de armamentos erguiam-se em todas as cidades do país. Nas minas, um operário ganhava 1,60 dólar caso conseguisse extrair 3 toneladas de carvão. Morava nos barracos da companhia e comprava alimento nos armazéns também da companhia. Nas fazendas de tabaco, os negros colhiam folhas 13 horas por dia, ganhando 6 centavos a hora, fosse homem, mulher ou criança. As crianças não sofriam discriminação. Eram apreciadas onde quer que se empregassem. Não se queixavam, conforme era hábito entre os adultos. Os patrões gostavam de considerá-las entezinhos felizes. Caso surgisse problema a respeito do emprego de crianças, referia-se apenas a sua resistência física. Eram mais ágeis que os adultos, mas tendiam, nas últimas horas do dia, a perder certo grau de eficiência. Nas fábricas de enlatados e nas usinas, em geral era nesse período que perdiam os dedos, imprensavam as mãos, ou esmagavam as pernas; precisavam ser orientadas no sentido de permanecer alertas. Nas minas trabalhavam na triagem do carvão e eram às vezes sufocadas nas rampas; avisavamnas então de que se mantivessem atentas. Uma centena de negros era linchada anualmente. Uma centena de mineiros era queimada viva. Uma centena de crianças era mutilada. Aparentemente havia quotas para tais coisas. Quotas para a morte pela fome. Havia também trustes de petróleo, trustes bancários, trustes de estrada de ferro, trustes da carne e truste do aço. Entrou em moda venerar o pobre. Em palácios de Nova York e Chicago organizavam-se bailes da pobreza e os convidados compareciam vestidos de andrajos, comiam em pratos de estanho e bebiam em canecas de esmalte descascado. Os salões eram decorados de modo a parecerem minas, com traves aparentes, trilhos e lanternas portáteis. Firmas de cenários teatrais eram contratadas para transformar jardins em sujas fazendas e salas de jantar em fábricas de algodão. Os convidados fumavam pontas de charuto oferecidas em bandejas de prata. Menestréis pintavam o rosto de preto. Uma anfitriã fez convites para um baile nas docas. Os convidados compareceram com longos aventais e cabeça coberta por gorro branco. Jantou-se e dançou-se sob as carcaças ensanguentadas dos bois, movimentadas ao redor da sala por meio de roldanas. Entranhas espalhavam-se pelo chão. Os lucros foram revertidos para obras de caridade". (pp. 41-42).
} 
Esse longo parágrafo, ao justapor o quadro de miséria e sofrimento da vida do trabalhador americano à ostentação dos ricos, ilustra bem o movimento que será constante na narrativa e se anuncia no encontro de Riis e White acima apresentado.

O parágrafo traz uma espécie de síntese do panorama social dos Estados Unidos nos primeiros anos do século XX. Nele, estão presentes: o elevado desemprego ("milhões de homens desempregados"); o fortalecimento das organizações de trabalhadores (“Os que tinham a sorte de ter um emprego ousavam organizar sindicatos”), que será retomado no episódio da vitória da IWW em Lawrence, Massachusetts; a resposta ideológica da direita à organização trabalhista ("Um sindicato era uma afronta a Deus. O operário não seria protegido e atendido por agitadores das massas, declarou um homem rico, mas por cristãos a quem Deus, em Sua infinita sabedoria, entregara o controle da propriedade e os interesses do país"); a resposta do estado à organização trabalhista ("Se tudo o mais falhasse, as tropas seriam convocadas. Fábricas de armamentos erguiam-se em todas as cidades do país"); as condições precárias de trabalho em várias atividades industriais; a exploração do trabalhador; o trabalho infantil; a concentração de capital ("trustes de petróleo, trustes bancários, trustes de estrada de ferro, trustes da carne e trustes do aço”), que será retomada na figura de J. P. Morgan e era ferrenhamente combatida nessa época pelos muckrakers, dentre os quais destaco Upton Sinclair com o seu The Jungle (1906) e o próprio Riis.

No mesmo parágrafo, justaposto ao quadro acima mencionado, apresenta-se o cinismo dos ricos na forma dos afrontosos "bailes da pobreza", nos quais os problemas sociais que ocupam a maior parte do parágrafo são cinicamente citados em uma infame mímica:

Os salões eram decorados de modo a parecerem minas (...) Firmas de cenários teatrais eram contratadas para transformar jardins em sujas fazendas e salas de jantar em fábricas de algodão. (...) Menestréis pintavam o rosto de preto. (...) Jantou-se e dançou-se sob as carcaças ensanguentadas dos bois.

Em um lance final de deboche, sabemos que os lucros alcançados com esses bailes são doados para caridade.

O capítulo, que começa inesperadamente como uma intromissão na narrativa da vida de Houdini e promete não ser mais que um interlúdio cômico, com referências ao incômodo de Freud ao não achar um banheiro público para se aliviar e a um passeio dele 
com Jung pelo “Túnel do amor”, termina com uma longa e densa incursão em um modo de contar mais próximo do documental e do histórico que do ficcional. Se há um potencial despolitizante no tratamento cômico e descompromissado de personagens históricos como Freud $^{390}$, o longo parágrafo que encerra o capítulo da visita do médico à América devolve à narrativa o caráter político nesse romance em que a luta de classes emerge nos momentos mais inesperados, como um lembrete da existência de tensões por trás da face alegre e próspera do sonho americano. Esse episódio mostra que em Ragtime os dois modos de narrar se misturam de forma criativa e repleta de energia crítica.

$$
* * *
$$

Além da presença de personagens históricos, há ocasiões no romance em que personagens ficcionais participam de eventos históricos. Isso ocorre no episódio da participação de Tateh e sua filha na grande greve de trabalhadores da indústria têxtil em Lawrence, Massachusetts, evento histórico que marcou uma das mais importantes vitórias do I.W.W. (Industrial Workers of the World) na história da organização e do movimento operário nos Estados Unidos ${ }^{391}$.

O episódio é retratado com minúcias de historiador. Estão lá representados o grande número de imigrantes que participou da greve, a diversidade de origens desse grupo e a atuação da IWW na organização do movimento ${ }^{392}$; a prisão sob falsas alegações

\footnotetext{
${ }^{390}$ Vários autores apontam o uso do cômico em Ragtime como elemento de despolitização do romance, como apresentado a seguir: "These comic games with history suggest the genre of an antihistorical novel whose purpose is political and whose effect is to breed distrust of both the process of history and the writing of history". (CUSHING, Strout. Border Crossings: History, Fiction, and Dead Certainties. History and Theory, Vol. 31, No. 2 (May, 1992), p. 161. Blackwell Publishing for Wesleyan University).
}

391 Como atestam Diggins and Weinstein: "Lawrence was the IWW's greatest victory" (WEINSTEIN, James. Ambiguous Legacy -The Left in American Politics. New York: New Viewpoints, 1975, p. 17.) "Occasionally the IWW organized as many as 30,000 workers; and, in 1912, during the height of its dame, it won a dramatic, long-fought textile strike in Lawrence, Massachusetts" (DIGGINS, John Patrick. The Rise and Fall of the American Left. New York, London: W.W. Norton \& Company, 1992, p. 79).

392 "The IWW became involved in a set of dramatic events in Lawrence, Massachusetts, in the year 1912, where the American Woolen Company owned four mills. The work force were immigrant families - Portuguese, French-Canadian, English, Irish, Russian, Italian, Syrian, Lithuanian, German, Polish, Belgian - who lived in crowded, flammable wooden tenements". 
de assassinato dos organizadores Ettor e Giovanitti ${ }^{393}$; a vinda de Big Bill Haywood para substituir os organizadores presos ${ }^{394}$ e a "cruzada das crianças", como ficou conhecida a remoção dos filhos dos trabalhadores em greve para abrigo temporário com famílias de trabalhadores solidários aos grevistas de Lawrence ${ }^{395}$.

Inicialmente animado pela mobilização maciça de trabalhadores nessa que seria umas das maiores greves da história americana, Tateh começa a se preocupar com o destino de sua filha vivendo sempre nas circunstâncias precárias que a vida de operário lhes impõe:

Tateh held her and wept to feel her frail body, her soft lips on his face. What if the truth was that he could do nothing more for her than make pictures? What if they just went on this way in varying

(ZINN, Howard. A People's History of the United States. New York: Harper \& Row, 1980, p. 327).

393 "The mayor called out the local militia; the governor ordered out the state police. A parade of strikers was attacked by police a few weeks after the strike began. This led to rioting all that day. In the evening, a striker, Anna LoPizzo, was shot and killed. Witnesses said a policeman did it, but the authorities arrested Joseph Ettor and another IWW organizer who had come to Lawrence, a poet named Arturo Giovanitti. Neither was at the scene of the shooting, but the charge was that 'Joseph Ettor and Arturo Giovanitti did incite, procure, and counsel or command the said person whose name is not known to commit the said murder..." (Idem, p. 328).

394 "With Ettor, head of the strike committee, in jail, Big Bill Haywood was called in to replace him" (Idem).

395 “On February 10, over a hundred children, aged four to fourteen, left Lawrence for New York City. They were greeted at Grand Central Station by five thousand Italian Socialists singing the 'Marseillaise' and the 'International'. The following week, another hundred children came to New York, and thirty-five to Bare, Vermont. It was becoming clear: if the children were taken care of, the strikers could stay out, for their spirit was high. The city officials in Lawrence, citing a statute on child neglect, said no more children would he permitted to leave Lawrence. Despite the city edict, a group of forty children assembled on February 24 to go to Philadelphia. The railroad station was filled with police, and the scene that followed was described to Congressmen by a member of the Women's Committee of Philadelphia:

When the rime approached to depart, the children arranged in a long line, two by two, in orderly procession, with their parents near at hand, were about to make their way to the train when the police closed in on us with their clubs, beating right and left, with no thought of children, who were in the most desperate danger of being trampled to death. The mothers and children were thus hurled in a mass and bodily dragged to a military truck, and even then clubbed, irrespective of the cries of the panic-stricken women and children...." (Idem, p. 329). 
degrees of unrealized hope? She would grow up and curse his name $^{396}$. (p. 123)

A força de ação de Tateh - e de outros trabalhadores - era diminuída pela ameaça de violência e privações a que sua filha era exposta junto a ele: “...there was a growing weakness in the unity of the strike front. A man with children found it difficult to keep his courage and resolve ${ }^{397 »}$ (p. 124). Uma grande mobilização para retirar as crianças da zona de conflito e colocá-las em local seguro foi organizada pela IWW. Tateh hesita novamente: "Tateh thought Here I am in the middle of brotherhood in action and I'm thinking like some bourgeois from the shtetl ${ }^{398 "}$ (p. 125).

Certos do impacto negativo desses comboios de crianças separadas de seus pais na imagem pública da indústria têxtil e das chances de que tal ação, sendo bem sucedida em Lawrence, fosse reproduzida com o mesmo efeito em outras mobilizações grevistas, as forças do governo agem com truculência para impedir a saída de mais trens com filhos de trabalhadores em greve. Em meio à violência policial, Tateh, atingido na cabeça e sangrando, agarra-se ao trem que leva sua filha e com ele parte. A cena marca a separação de Tateh do destino da classe trabalhadora e seu ingresso em um caminho de individualismo que vai atualizar o mito do self-made man:"He [Tateh] felt he deserved his happiness. He'd constructed it without help" (p. 258). A cena da "libertação" de Tateh é carregada de simbolismo e tem sua carga dramática aumentada pelo emprego da sintaxe cumulativa:

He started to run. Tateh, Tateh! As he ran the train slowly began to move. He ran onto the tracks. He ran, stumbling, with his arm out. His hands caught the guardrail of the observation platform. The train was picking up speed. His feet were coming off the ground. The ties began to blur under him. He clung to the railing, finally hoisting his knees to the platform overhang and clinging there with

\footnotetext{
396 "Tateh abraçou-a e chorou ao sentir-lhe o corpo frágil, os lábios macios contra seu rosto. E se nada pudesse fazer por ela além de desenhar figurinhas? E se continuassem assim em variáveis graus de esperança não concretizada? Ao crescer, a menina amaldiçoaria seu nome.” (p. 111).

397 “....tornava-se cada vez mais fraca a unidade na frente grevista. Um pai de família achava difícil manter a coragem e a resolução.” (p. 111).

398 “Tateh pensou: Cá estou eu em meio à fraternidade em ação e pensando como qualquer burguês do shtetl." (p. 113).
} 
his head pressed against the bars like a man in prison begging to be set free ${ }^{399}$. (p. 128)

O longo último período destoa da sintaxe cumulativa do resto do parágrafo e sugere o esforço contido no último fôlego de Tateh antes dele desistir do socialismo e mergulhar na loteria do sonho americano.

O trem os leva até a Filadélfia onde, em um lance de sorte, Tateh encontra um representante da Franklin Novelty Company interessado nos "livros móveis" que ele fazia para distrair sua filha. Com vinte e cinco dólares pelo livro apresentado e um contrato para a produção de outros mais, Tateh começa sua ascensão e reflete sobre o que deixa para trás:

From this moment, perhaps, Tateh began to conceive of his life as separate from the fate of the working class. I hate machines, he said to his daughter. He stood and she stood and took his hand and together they looked for the exit. The I.W.W. has won, he said. But what has it won? A few more pennies in wages. Will it now own the mills? No ${ }^{400}$. (p. 131)

Deixamos Tateh na porta de saída da Franklin Novelty Company para só reencontrá-lo no final do romance, agora como um rico empresário do cinema conhecido como Barão Ashkenazy. A autoimposta mudança de nome e o acréscimo de um título de nobreza a ele simbolizam a transformação do operário imigrante socialista Tateh em rico empresário, que agora se nomeia vulgarmente como "Buffalo Nickel Photoplay, Incorporated":

With a mischievous look he took a shiny coin from his pocket and flipped it into the air. It went nearly as high as the ceiling. Everyone

399 "Tateh! Tateh! Ele olhou para trás e viu, nos trilhos, o último vagão do trem para Filadélfia, logo após o fim da estação. O trem estava parado. Disparou a correr, enquanto o trem começava a se movimentar devagar. Saltou para os trilhos. Correu, tropeçando, braços estendidos. As mãos agarraram a grade da plataforma de observação. $O$ trem ganhava velocidade. Seus pés começaram a desligar-se do chão. Os dormentes começaram a passar indistintos. Agarrou-se à grade, conseguindo finalmente erguer os joelhos até a plataforma e ali imobilizar-se, a cabeça premida contra as barras, como um prisioneiro suplicando para ser libertado." (p. 115).

400 "Naquele momento, quem sabe, Tateh começou a conceber sua vida isolada do destino da classe operária. Detesto máquinas, disse à filha. Levantou-se, ela imitou-o, tomou-lhe a mão e juntos procuraram a saída. O sindicato dos operários venceu, disse consigo mesmo. Mas, que conseguiu? Alguns centavos de aumento nos salários? Passará a ser dono das fábricas? Não.” (p. 117). 
watched it. The Baron caught the coin and flattened his hand on the table with a loud smack. The silver jumped. The water shook in the glasses. He lifted his hand, revealing one of the popular new fivecent pieces, a buffalo nickel. (...) How I named myself, the Baron said with delight. I am the Buffalo Nickel Photoplay, Incorporated $!^{401}$ (p. 257)

A trajetória de Tateh no romance é um retrato irônico, e ao mesmo tempo desencantado, daquilo que Doctorow chamou de "our great operative myth of rugged individualism ${ }^{402}$ ". Ele explica a presença desse mito na sociedade americana e suas consequências para a organização da classe trabalhadora em torno de interesses em comum:

The notion that we are the self-reliant independent entrepreneurs of ourselves is a national heritage. Working people in the United States, unlike their European counterparts, refuse to identify themselves as a class. They tend to define themselves not by their work but by what they own from their work, or by their ethnic background, or their social activities. For the independent entrepreneur of himself there can be upward mobility, at least across generations, and there is the road - he can hit the road when things go bad, pull up stakes and move on ${ }^{403}$.

De fato, quando as coisas pioraram, Tateh "caiu na estrada". No romance, o destino desse personagem é central na dialética da riqueza e da exclusão que perpassa toda a narrativa. Do lado do sonho americano, temos personagens como J. P. Morgan, Papai, Harry Houdini, Harry K. Thaw, Henry Ford, Booker T. Washington, Stanford White. Do lado dos excluídos, temos Emma Goldman, Irmão Mais Novo (que se alia aos excluídos ao lutar ao lado de Coalhouse Walker e depois ao lado de Zapata, no México, onde morre), Evelyn Nesbit (que vai da pobreza à riqueza e de volta a pobreza, sempre um instrumento disponível ao prazer dos ricos White e Thaw. Sua trajetória é exemplar

\footnotetext{
401 "Olhar malicioso, tirou uma moeda do bolso e jogou-a para o alto. A moeda chegou quase ao teto. Todo mundo olhou. O Barão apanhou-a e bateu ruidosamente com a palma da mão na mesa. A moeda saltou. A água estremeceu nos copos. Erguendo a mão revelou uma das novas moedas de cinco centavos, um búfalo. (...) Arranjei um nome para mim, declarou o Barão, encantado. Sou o Buffalo Nickel Photoplay, Incorporated!" (pp. 222-223).

${ }^{402}$ DOCTOROW, E. L. Creationists - selected essays (1993-2006). New York: Random House, 2007, p. 95.

${ }^{403}$ Idem, p. 94.
} 
do destino de muitas garotas da classe trabalhadora, e é isso que a aproxima de Goldman, da filha de Tateh e de Sister Carrie), Jacob Riis, Coalhouse Walker e uma multidão de anônimos. A invasão da casa de Morgan - "o clássico herói americano, o homem nascido no seio de extrema riqueza e que, graças ao trabalho árduo e à crueldade, multiplicara a fortuna da família” (pp. 122-123) - por Coalhouse Walker e sua gangue é o clímax dessa dialética. Eles escolhem Morgan como alvo do ataque final por acreditarem que esse magnata "mais que qualquer prefeito ou governador, representa na mente de Coalhouse o poder do mundo branco. Há anos era retratado em cartoons e caricaturas, de charuto e cartola, como a encarnação do poder” (p. 232). Ao final do romance, Walker é morto e a ordem é restabelecida, mas as vozes do "outro lado" (Riis) se fizeram ouvir e ecoaram seu canto de guerra de forma estridente.

Tateh é central nessa dialética da riqueza e da exclusão. Ele passa de um lado ao outro com sucesso, personificando o sonho americano e o mito de individualismo feroz que, como o próprio Doctorow apontou, atuam contra a mobilização da classe trabalhadora. Vemos esse papel de Tateh na configuração social recriada no romance ser expresso na passagem a seguir:

Thus did the artist point his life along the lines of flow of American energy. Workers would strike and die but in the streets of cities an entrepreneur could cook sweet potatoes in a bucket of hot coals and sell them for a penny or two. A smiling hurdy-gurdy man could fill his cup. Phil the Fiddler, undaunted by the snow, cut away the fingers of his gloves and played under the lighted windows of mansions. Frank the Cash Boy kept his eyes open for a runaway horse carrying the daughter of a Wall Street broker. All across the continent merchants pressed the large round keys of their registers ${ }^{404}$. (p. 134)

É significativo que a trajetória de Tateh rumo à realização do prometido sonho americano tenha se iniciado na greve de Lawrence de 1912. O aparente sucesso dessa

\footnotetext{
404 “Assim o artista orientou sua vida segundo o fluxo da energia americana. Operários fariam greve e morreriam, mas nas ruas das cidades, um homem empreendedor poderia cozinhar batata doce num balde de carvões em brasa e vendê-las por um ou dois centavos. Um tocador de realejo sorridente seria capaz de encher sua caneca. Phil, o Violinista, sem se deixar intimidar pela neve, cortava os dedos das luvas e tocava sob as janelas iluminadas das mansões. Frank, o Rapaz do Dinheiro, mantinha-se de olhos abertos à procura de um cavalo foragido transportando a filha de um corretor de Wall Street. Em todo o continente, os negociantes comprimiam as gordas teclas de suas caixas registradoras." (p. 119).
} 
mobilização (a greve terminou com algumas conquistas dos operários e com um saldo positivo de opinião pública) elevou a moral de trabalhadores e militantes de esquerda por um curto período. No longo prazo, a greve de Lawrence se revelou o último suspiro da IWW e uma das últimas grandes mobilizações operárias nos Estados Unidos. A partir daí, conflitos entre organizações de trabalhadores, políticas de incentivos internos nas empresas - que promovem a desmobilização de classe e o individualismo - e a atuação "pragmática" dos sindicatos foram acabando com o poder de mobilização dos trabalhadores. $\mathrm{O}$ desencanto político traduzido na figura de Tateh e o simbolismo contido no fato de que sua "libertação" da classe trabalhadora tenha ocorrido no episódio de Lawrence, 1912, pode ser visto nessa leitura contemporânea da história da IWW:

The Lawrence uprising had been a thing of beauty for the textile workers and their revolutionary spokesmen. Upton Sinclair later dubbed it "the Bread and Roses" strike, after a contemporary poem in which picketing women remark, "Hearts starve as well as bodies; give us bread, but give us roses." But the aftermath of the big strike revealed that, for all its romantic élan, the IWW was an organization of beautiful losers ${ }^{405}$.

O pessimismo em relação ao poder de mudança da classe operária organizada que o socialista Tateh exprime não é historicamente verossímil. Na época da greve em Lawrence, havia um grande otimismo em relação às possibilidades do socialismo nos Estados Unidos. No mesmo ano, Eugene Debs, um dos fundadores da IWW, alcançou a maior votação de um candidato de esquerda em uma eleição americana. Concorrendo pelo Partido Socialista, Debs ultrapassou a marca de 900.000 votos, número expressivo para um candidato que não era nem Republicano nem Democrata. O desânimo político de Tateh está mais próximo do estado de coisas dos anos 70 (década em que o romance foi escrito e publicado) e é irmão do espírito de derrota impresso na leitura dos "Wobblies" como "beautiful losers".

A genialidade de Doctorow está em figurar na trajetória de Tateh o prenúncio dos rumos que a história da classe trabalhadora tomará no decorrer do século e, ao mesmo tempo, mostrar o engodo por trás do sonho americano, uma vez que, na dialética da riqueza e da exclusão que perpassa o enredo, a saída de Tateh é uma solução individual

\footnotetext{
${ }^{405}$ KAZIN, Michael. American Dreamers - How the Left changed a nation. New York: Vintage
} Books, 2012, p. 129. 
que existe como opção para poucos (no caso de Tateh, tudo começou num lance de sorte, num encontro casual com o destino). A mesma opção não se deu para Coalhouse Walker Jr e para Evelyn Nesbit, por exemplo. O saldo final do romance é a manutenção da luta de classes expressa na dialética da riqueza e da pobreza, com a exceção do caso de Tateh, que escapa, sozinho, das garras da pobreza e muda de lado. Contudo, há um saldo positivo na figuração - que, como vimos, é constante no romance - do conflito de classes nos Estados Unidos das primeiras décadas do século XX. Ela traz para o leitor contemporâneo a imagem de uma sociedade injustamente dividida, imagem que pode acionar, por um processo de correspondências, a consciência de que o mundo atual não resolveu os conflitos do passado. A professora Iná Camargo Costa, em prefácio do livro que reúne as peças da necessária Companhia do Latão, fala da importância de formas artísticas que, no momento atual, relembrem a presença da luta de classes no mundo capitalista, presença cuja obviedade é maquiada pela força da ideologia:

Luta de classes é a luta pela redistribuição da propriedade e de todos os recursos produzidos pela sociedade como um todo. Está sendo travada todos os dias - mas nos últimos tempos é a burguesia que vence a cada confronto. Os ideólogos dizem que ela foi neutralizada, mas isto é falso e esta falsificação faz parte da própria luta. Uma das artimanhas dos atuais vitoriosos é dizer que não há mais luta de classes ${ }^{406}$.

A fraqueza de decisão política do imigrante judeu socialista do Lower East Side transformado em "barão" da indústria do entretenimento é semelhante a de outros personagens politicamente anêmicos ou indecisos, como Daniel, Langley e Homer Collyer e o pragmático Arly, que passa de um lado a outro da Guerra Civil Americana com seu pragmatismo ${ }^{407}$.

\footnotetext{
${ }^{406}$ CAMARGO, Iná Costa. Prefácio de Companhia do Latão - 7 peças. In: CARVALHO, Sérgio de, MARCIANO, Márcio. Companhia do Latão - 7 peças. São Paulo: Cosac Naify, 2008, p. 17.

407 "Yes, we are wet and cold and hungry on this dark November night, but alive, which is a sight better than the dead falling to the ground every minute in every state of the Confederacy. And that we are alive by shifting our way about from one side t'other as the situation demands shows we already have something gifted about us." (DOCTOROW, E. L. The March. New York: Random House, 2006, p. 64).
} 
Podemos ver na obra de Doctorow um grande esforço de mapear as possibilidades do pensamento radical nos Estados Unidos, e esses personagens dão face ao pessimismo geral contemporâneo sobre a política.

$$
* * *
$$

Robert Altman chegou a planejar com Doctorow uma versão de Ragtime para o cinema. O filme teria cerca de seis horas - o que é bem coerente com a riqueza do panorama desenhado no livro. O projeto não se concretizou e dele pouco se sabe. Em uma das poucas referências a esse projeto, vemos Altman falar que Tateh é o herói de Ragtime 408 , o que nos permite supor que esse personagem ocuparia um papel de destaque no filme.

Vimos, até aqui, como os dados históricos são manipulados em Ragtime para iluminar fatos sociais importantes, como o conflito de classes - conteúdo subjacente ao enredo. Vimos o choque de tendências opostas no encontro de Jacob Riis e Stanford White. Vimos o conflito emergir no trecho que aparece imediatamente após o diagnóstico de Freud sobre a América e vimos o conflito de classes na sua manifestação clássica no episódio histórico de Lawrence, Massachusetts.

A escolha dos personagens históricos que integram o enredo de Ragtime não é, como espero ter mostrado, aleatória e apenas anedótica. Os personagens que entram na narrativa representam tendências de sua época que o autor deseja evocar: "These people occurred to me - and specifically these people, Morgan, for instance, not Andrew Carnegie - because they carried for me the right overtones of the time ${ }^{409}$ ".

Para não ficar repetitivo, vou me limitar aos exemplos acima expostos. Poderíamos ainda analisar as relações iluminadoras em Ragtime de Emma Goldman e Evelyn Nesbit (na qual a anarquista vê a trajetória da "deusa sexual" como exemplar do

\footnotetext{
${ }^{408}$ MORRIS, op. cit., p. 23.

${ }^{409}$ DOCTOROW. In: MORRIS, op. cit., p. 1.
} 
destino das mulheres da classe trabalhadora ${ }^{410}$ ) e Morgan e Ford (um, o "monarca do invisível, transnacional reino do capital"; o outro, aperfeiçoador da linha de montagem, que, para Morgan, é a "projeção de uma verdade orgânica” (p. 129), qual seja, “o caráter intercambiável das partes é uma regra da natureza" (p. 129)).

\section{O tema da representação}

Como vimos, os romances históricos de Doctorow incorporam reflexões sobre a construção de imagens do passado e sobre o conteúdo de verdade que tais imagens podem trazer.

Em Ragtime, o tema da representação surge no capítulo 4, em que o narrador apresenta com mais detalhes a personagem Evelyn Nesbit. No último parágrafo do capítulo, o narrador conta as dificuldades de Theodore Dreiser, romancista naturalista americano, com seu romance Sister Carrie e com a busca de uma "proper alignment":

Coincidentally this was the time in our history when the morose novelist Theodore Dreiser was suffering terribly from the bad reviews and negligible sales of his first book, Sister Carrie. Dreiser was out of work and too ashamed to see anyone. He rented a furnished room in Brooklyn and went to live there. He took to sitting on a wooden chair in the middle of the room. One day he decided his chair was facing in the wrong direction. Raising his weight from the chair, he lifted it with his two hands and turned to the right, to align it properly. For a moment he thought the chair was aligned, but then decided it was not. He moved it another turn to the right. He tried sitting in the chair now but it still felt peculiar. He turned it again. Eventually he made a complete circle and still he could not find the proper alignment for the chair. The light faded on the dirty window of the furnished room. Through the night Dreiser turned his chair in circles seeking the proper alignment ${ }^{411}$. (pp. 26-27)

410 "In Seattle, for instance, Emma Goldman spoke to an I. W. W. local and cited Evelyn Nesbit as a daughter of the working class whose life was a lesson in the way all daughters and sisters of poor men were used for the pleasure of the wealthy." (p. 84).

411 "Por coincidência, foi a essa altura de nossa história que o rabugento romancista Theodore Dreiser sofreu profundamente com as críticas adversas e a pouca vendagem de seu primeiro livro, 
O advérbio no início do parágrafo ("Coincidentally”) sugere uma aproximação entre Sister Carrie, personagem ficcional, e Evelyn Nesbit, personagem histórico, uma vez que nos parágrafos anteriores a narração vem se concentrando na trajetória de Nesbit. Também sugere uma aproximação entre a dificuldade de Dreiser de encontrar um "alinhamento apropriado" - aqui metáfora para um ângulo de representação que permita um enquadramento adequado do "real" 412 - e os dilemas da forma e da representação da história em Ragtime. Assim, o romance tematiza sua própria dificuldade em representar, como acontece em outras obras de Doctorow. Para Jesús Benito Sánchez, em Ragtime Doctorow oferece uma resposta para os problemas de representação que atormentam Dreiser na passagem citada acima:

Ragtime is Doctorow's response to Dreiser's struggle to align his chair properly, in one single direction, as well as to the problems posed by the unidirectionality of the camera in photographs and moving pictures, or the emptiness of the silhouette. As if to avoid the problem of having to 'align' his novel on a certain fixed direction, Doctorow refuses to offer the narrative voice of the novel to an individual character, or even to an omniscient narrator ${ }^{413}$ ".

Aqui, como em outros casos já vistos, Doctorow parte de um dado histórico para construir uma leitura simbólica desse fato. Em ensaio, Doctorow revela o fato da vida de Dreiser que serviu de partida para a criação da passagem acima:

...Dreiser's frank account of his life in Brooklyn and New York in the year 1903, the aftermath of Carrie's disastrous publication, when he had lost his ability to write and to earn a living, and thought seriously of suicide.

Sister Carrie. Dreiser estava desempregado, sem dinheiro e demasiado envergonhado para visitar quem quer que fosse. Alugando um quarto mobiliado no Brooklyn, passou a viver ali. E adquiriu a mania de sentar-se numa cadeira de madeira no meio do quarto. Certo dia concluiu que a cadeira estava voltada na direção errada. Levantando-se, ergueu-a com ambas as mãos e virou-a para a direita, a fim de alinhá-la corretamente. Por um instante julgou que estivesse bem alinhada, mas em seguida decidiu que não. E deu mais uma volta para a direita. Tentou sentar-se, mas achou que a cadeira continuava um tanto esquisita. Voltou-a novamente. E completou um círculo sem encontrar a posição correta. A claridade foi desaparecendo da suja vidraça do quarto alugado e Dreiser passou a noite inteira em círculos, procurando a posição correta.” (p. 31).

${ }^{412}$ Conforme se sabe, Dreiser era um romancista naturalista, escola que se propõe construir retratos "cientificamente" exatos da sociedade.

${ }^{413}$ SÁNCHEZ, op. cit., p. 20. 
"Mine was a serious case of neurasthenia - or nervous prostration," he tells us, writing in 1904, the year of his recovery. "It had begun with the conclusion of a novel which I had written three years before and which exhausted me greatly... I was morbid, had fearful dreams, slept very little... I was constantly most gloomy and depressed - almost to a state of tears... My nerves began to hurt me, particularly in the ends of my fingers in which I felt genuine pain... I began to have the idea, or the almost irresistible impulse to turn around in a ring. That is, if I were sitting in a chair, I would want to keep turning to the right - an involuntary nervous discharge of will... ${ }^{414}$

Para Doctorow, Dreiser representa como autor um tipo de engajamento que pode servir de exemplo para os escritores hoje: "What he has rather is a concern for the moral consequence of life that is so pervasive as to constitute a vision ${ }^{415}$ ". Em entrevista, Doctorow fala da inquietação do escritor hoje por não conseguir estabelecer um elo de consequência entre o destino coletivo e o privado ${ }^{416}$ (retomarei essa afirmação do autor no próximo capítulo). O que Doctorow chama de uma "perda de consequência 417 " entre o destino do indivíduo e a esfera do coletivo é sugerido na dificuldade de Dreiser de encontrar o alinhamento adequado. No entanto, Dreiser ainda busca esse alinhamento. Vemos o mesmo esforço em Ragtime, sobretudo na exploração simbólica de personagens reais como representantes de tendências históricas e na trajetória de Tateh como representativa da consciência sobre a existência de classes sociais nos Estados Unidos.

Em outra passagem do livro, o explorador polar Robert Peary ${ }^{418}$ é visto em dificuldades para encontrar, em meio ao mundo congelado e instável do extremo norte do planeta, o ponto exato do polo físico para fixar a bandeira americana e marcar a conquista do Polo Norte. Aos temas da instabilidade e mutabilidade, presentes nessa passagem, soma-se o da indefinição na representação de fatos históricos: o único documento que

\footnotetext{
${ }^{414}$ DOCTOROW, E. L. Jack London, Hemingway, and the Constitution: selected essays, $1977-$ 1992. New York: Random House, 1993.

${ }^{415}$ DOCTOROW, op. cit.

${ }^{416}$ DOCTOROW. In: MORRIS, op. cit., p. 66.

${ }^{417}$ Idem.

${ }^{418}$ Personagem histórico. Junto com Matthew Henson, alcançou o Polo norte pela primeira vez na história, em 1909.
} 
comprovaria o feito de Peary, uma fotografia, está prejudicado pela luz da região e não pode atestar definitiva e inequivocamente o fato histórico que ali se pretendia registrar:

On this watery planet the sliding sea refused to be fixed. He couldn't find the exact place to say this spot, here, is the North Pole. Nevertheless there was no question that they were there. All the observations together indicated that. Give three cheers, my boy, he told Henson. And let's fly the flag. Henson and the Esquimos cheered loudly but could not be heard in the howling wind. The flag snapped and rippled. Peary posed Henson and the Eskimos in front of the flag and took their picture. It shows five stubby figures wrapped in furs, the flag set in a paleocrystic peak behind them that might suggest a real physical Pole. Because of the light the faces are indistinguishable, seen only as black blanks framed by caribou fur $^{419}$. (pp. 80-81)

A indefinição entre fato e ficção, entre o real e o imaginado é a própria matéria da arte de Harry Houdini. Esse personagem histórico é, no romance, aquele que mais transita entre os espaços da ilusão e da realidade. Em certo momento da narrativa, Houdini chega perigosamente próximo de perder completamente o senso de distinção entre os dois

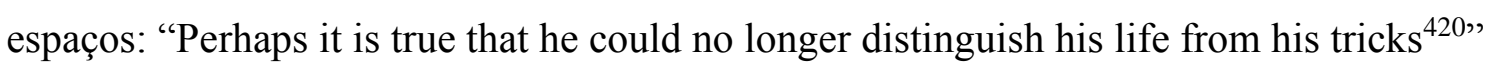
(p. 204).

Ao longo do romance, as apresentações de Houdini vão ganhando em ousadia e perigo. O "artista da fuga", como era conhecido, cria com seus números ilusões tão perfeitas que em determinado ponto da narrativa ${ }^{421}$ um fato acontecido fora do teatro - a explosão por Coalhouse Walker e seu grupo da estação dos bombeiros voluntários que vandalizaram o seu Ford Modelo T - é experimentado pela plateia como uma ilusão

\footnotetext{
419 "Naquele planeta aquoso, o oceano deslizante recusava a se fixar. Não conseguia encontrar o ponto exato para dizer: Este lugar aqui é o Polo Norte. Contudo, não havia dúvidas de que ali se encontravam. Todas as observações o indicavam. Três hurras, meu rapaz, disse a Henson. E vamos hastear a bandeira. Henson e os esquimós gritaram com toda a força, mas não foram ouvidos devido aos uivos do vento. A bandeira ondulou e tremulou. Peary dispôs Henson e os esquimós diante dela e tirou uma foto. A foto mostra cinco silhuetas atarracadas, envoltas em peles, a bandeira encravada num pico paleocrístico à retaguarda, sugerindo o verdadeiro Polo físico. Por causa da luz os rostos estão indistintos, não passam de manchas escuras, emolduradas por peles de caribu". (p. 76).

420 “Talvez fosse verdade que já não conseguia distinguir entre sua vida e os truques.” (p. 177).

${ }^{421}$ Esse episódio acontece no Capítulo 28.
} 
assustadoramente realista. Após a explosão e o susto da plateia, o narrador nos informa que

Actually the blast occurred two miles away at the borders of the city in its west end. The station house of the Emerald Isle Engine had exploded, firing the field across the street with burning timbers and lighting the sky over Westchester ${ }^{422}$ (p. 206).

Aqui, as fronteiras entre o real e o inventado estão confusamente embaralhadas: um ato fictício, apenas existente no livro (a explosão por Coalhouse da estação dos bombeiros), mas real no universo diegético criado pelo romance, interfere em um ato que poderia ser histórico (uma apresentação do mágico Harry Houdini, personagem real), sendo percebido como ilusão por sua plateia. Dessa forma, nesse trecho o fíctício (o ato de Coalhouse) é real - no romance, é claro - e interfere conferindo um ar de veracidade a um ato fictício (a apresentação de Houdini), que, no entanto, é baseada em fatos reais (Houdini existiu e seus ousados espetáculos ilusionistas também). Assim, podemos dizer que, nessa passagem do romance, o ato do fictício Coalhouse Walker Jr é real, enquanto o ato do real Houdini é fictício.

Houdini dedica sua vida ao aperfeiçoamento de suas escapadas. Na sua dedicação, ele reflete um ideal americano, como nos informa o narrador: "... his self-imposed training, his dedication to the perfection of what he did, reflected an American ideal ${ }^{423}$ " (p. 31). O seu sucesso cresce com o aperfeiçoamento e com a dificuldade cada vez maior de suas escapadas. No entanto, Houdini não se satisfaz com o sucesso de seus truques:

Houdini opened his European tour at the Hansa Theatre in Hamburg. The audiences were enthusiastic. The papers gave him lots of space. He had never known such feelings of dissatisfaction. He wondered why he had devoted his life to mindless entertainment. The audiences cheered ${ }^{424 "}$ (p. 101).

\footnotetext{
422 "Na verdade a explosão ocorrera a três quilômetros de distância, nos limites ocidentais da cidade. O posto de bombeiros de Emerald Isle Engine fora pelos ares, incendiando o terreno baldio do outro lado da rua com madeira em chamas e iluminando o céu de Westchester." (p. 178).

423 "Seu treinamento feito por autoimposição, sua fidelidade à perfeição refletiam um ideal americano." (p. 34).

424 "Houdini iniciou sua turnê pela Europa no Hansa, de Hamburgo. O público mostrou-se entusiasmado. Os jornais concederam-lhe amplo espaço. Jamais se sentira tão insatisfeito. Perguntava por que dedicara a vida ao entretenimento ocioso. O público aplaudia.” (p. 92).
} 
Houdini está mais interessado nos "atos do mundo real", nos atos reais que causam consequências reais no mundo, como a rebelião de Coalhouse Walker Jr. O mágico se ressente de seu papel de ilusionista e entertainer:

There was a kind of act that used the real world for its stage. He couldn't touch it. For all his achievement he was a trickster, an illusionist, a mere magician. What was the sense of his life if people walked out of the theatre and forgot him? The headlines on the newsstand said Peary had reached the Pole. The real-world act was what got into the history books ${ }^{425}$ (p. 99).

Ironicamente, o próprio "ato do mundo real" de Peary está sob suspeita nesse romance de incertezas.

Assim, para buscar os atos no mundo real, Houdini se aventura na exploração aérea: ele compra e aprende a voar um Voisin. Um dia, enquanto voava pelos campos da Alemanha, o mágico é visitado pelo Arquiduque Franz Ferdinand, que lhe pede um voo de demonstração. Ironicamente, Houdini, que antes desse encontro recebera do Menino a incumbência de alertar o "duque", tem a chance de praticar um verdadeiro "ato do mundo real" e entrar nos livros de história ${ }^{426}$. Ele não o faz e, anos mais tarde, quando está pendurado com a cabeça para baixo na Times Square, recebe a notícia do assassinato do Arquiduque e se lembra do recado do Menino:

He was upside down over Broadway, the year was 1914, and the Archduke Franz Ferdinand was reported to have been assassinated. It was at this moment that an image composed itself in Houdini's mind. The image was of a small boy looking at himself in the shiny brass headlamp of an automobile ${ }^{427}$ (p. 316).

425 "Havia um espetáculo que utilizava o mundo real como palco e a este ele não conseguia alcançar. Apesar de todas as realizações, era um vigarista, um ilusionista, um simples mágico. Que sentido teria a sua vida se as pessoas ao saírem do teatro o esquecessem? As manchetes dos jornais diziam que Peary chegara ao Pólo. Eram os feitos da vida real que ingressavam nos livros de história." (p. 90).

${ }^{426}$ É importante lembrar que, em um ato de extrema modificação dos fatos históricos, Doctorow chega a escrever a cena em que Houdini alerta o duque e tenta, com isso, mudar os rumos da história. Que essa cena tenha sido retirada do romance é prova de que há limites de figuração ao livre jogo com dados históricos.

427 "Estava de cabeça para baixo sobre a Broadway, em 1914, ano em que o Arquiduque Francisco Ferdinando fora assassinado. Naquele momento, uma imagem estampou-se na mente de Houdini: um meninozinho mirando-lhe no brilhante farol de um automóvel." (p. 274). 
O questionamento sobre a representação da história atinge seu ponto mais crítico nessa intromissão de um elemento estranho na diegese do romance: a premonição. A visão do Menino sobre a morte de arquiduque cria um estranhamento diegético que coloca em suspensão a própria narrativa: a partir desse dado, como definir os limites, dentro do romance, entre a narração de fatos conhecidos do narrador e fatos criados por ele?

Houdini esteve perto de adiar um dos acontecimentos mais importantes do século XX: a deflagração da Primeira Guerra Mundial. Aqui, o recado do livro é ambíguo: a guerra, cuja iminência é anunciada logo nas primeiras páginas do livro no aviso do Menino a Houdini, poderia, num gesto do artista da ilusão, ser evitada? Ou isso não poderia ocorrer e o aviso do Menino nas primeiras páginas do romance é um prenúncio trágico desse evento inevitável?

Além do episódio do Voisin, a busca de Houdini pelos "atos do mundo real" incluem um encontro com um operário hospitalizado que sobrevive milagrosamente a uma explosão debaixo da terra - em um dos vários acidentes reais acontecidos durante a construção da ponte do Brooklin - e uma série de sessões de desmascaramento de charlatões espirituais, fato este biográfico.

A figura de Houdini em Ragtime é paradoxal: um ilusionista que se dedica à busca de atos significativos no mundo real. Ela epitomiza a relação entre fato e ficção em Ragtime: um romance histórico que questiona, desconfia ou ironiza o próprio conhecimento histórico que lhe serve de matéria prima. Para Jesús Benito Sánchez, Houdini emerge na obra como uma metáfora do romance: "Houdini... emerges as a clear parallel of the novel itself. (...) In his well balanced combination of factuality and fictionality, he is the maximum metaphor of the novel itself ${ }^{428}$ ". Acrescentemos que essa é uma metáfora do paradoxo desse romance histórico que enfrenta uma dificuldade de representação que é simultaneamente obstáculo e motor de sua forma.

${ }^{428}$ SÁNCHEZ, op. cit., p. 20. 


\section{Linguagem e estilo de Ragtime: Distância narrativa e "imitação cômica de tom histórico ${ }^{429}$ ",}

Ragtime tem levantado questões sobre os limites entre formas de historicismo consciente no romance e o simples culto contemporâneo da nostalgia. Não é possível incluir o romance inequivocamente em qualquer dos lados dessa questão. O que venho mostrando aqui é como a forma do romance em Ragtime apresenta dilemas produtivos que obrigam a reanálise de categorias de interpretação restritas e atestam como são imprecisas e epistemologicamente problemáticas categorizações e conceitos amplos como "metaficção historiográfica".

Doctorow reage às críticas de que seu romance adere à "cultura da nostalgia" adicionando mais um dado ao debate sobre a forma em Ragtime: "I would agree that nostalgia is an inadequate self-deluding emotion. (...) It is the disposition for nostalgia that Ragtime mocks ${ }^{430}$ ". Para alcançar uma imitação cômica das narrativas de nostalgia Doctorow busca uma ideia de composição a uma distância narrativa fixa em relação ao fato histórico trabalhado, mas que não seja nem tão fria e "imparcial" como a escrita historiográfica nem tão próxima quanto à ficção moderna ${ }^{431}$. Com isso, o autor busca se situar em uma região entre a ficção e o "jornalismo moderno ou a história":

I became acutely aware of narrative as opposed to fiction. The most conscious technical idea I worked with as I proceeded was the idea of the rigorous narrative which, combined with a certain distance to the characters, allowed me to produce a kind of reality that I really liked, that existed somewhere between fiction and modern journalism or history, sort of an in between region ${ }^{432}$.

\footnotetext{
${ }^{429}$ O termo usado por Doctorow é "mock-historical tone".

${ }^{430}$ MORRIS, op. cit., p. 36.

431 "In Ragtime it was the historical imagery and the mock-historical tone which most interested me. And the idea of composition at a fixed narrative distance to the subject, neither as remote as history writing - which is very, very distant from what is being described - nor as close as modern fiction, which is very intimate with the subject" (MORRIS, op.cit., p. 79).
}

${ }^{432}$ DOCTOROW. In: MORRIS, op. cit., p. 9. 
Doctorow encontrou na obra de Heinrich Von Kleist o modelo de distância narrativa adequado para o que pretendia fazer em Ragtime ${ }^{433}$. A opção de Doctorow pela crônica histórica como modelo narrativo traz implicações formais importantes. Comparando as quatro formas mais comuns de organização do conteúdo histórico em texto (os anais, a crônica, a narrativa histórica e a filosofia da história), Hayden White estabelece uma gradação do menor grau de fechamento narrativo (presente nos anais, que são apenas listas de eventos organizados cronologicamente) ao maior (presente nas filosofias da história) ${ }^{434}$. Nessa escala, a crônica, apesar de aspirar à narratividade, é marcada por uma falha de fechamento narrativo ${ }^{435}$.

O mesmo não ocorre em Ragtime. Embora não haja um enredo único que centralize e conecte as várias histórias contadas no livro, a maioria delas se fecha: Coalhouse Walker consegue a restituição de seu Modelo T e depois é morto; o Irmão Mais Novo morre em combates no México; Emma Goldman é deportada; Tateh, agora Barão Ashkenazy, casa-se com Mamãe (assumindo, simbolicamente, o lugar de Papai, que temia a vinda de imigrantes aos Estados Unidos $^{436}$ ) e segue uma próspera carreira no cinema; Papai morre no ataque ao Lusitânia. O fechamento das narrativas é evidente nas linhas que encerram o romance:

433 "I was aiming for the narrative distance of the historical chronicle that you find, for instance, in Kleist who, of course, was very important in the composition of that book" (DOCTOROW. In: MORRIS, op. cit., p. 79).

434 WHITE, Hayden. The Content of the Form - Narrative Discourse and Historical Representation. Baltimore: The Johns Hopkins University Press, 1992.

435 "Needless to say, also, the annals form lacks completely this narrative component, since it consists only of a list of events ordered in chronological sequence. The chronicle, by contrast, often seems to wish to tell a story, aspires to narrativity, but typically fails to achieve it. More specifically, the chronicle usually is marked by a failure to achieve narrative closure. It does not so much conclude as simply terminate. It starts out to tell a story but breaks off in medias res, in the chronicler's own present; it leaves things unresolved, or rather, it leaves them unresolved in a storylike way." (WHITE, op. cit., p. 5).

436 "A while later the Roosevelt passed an incoming transatlantic vessel packed to the railing with immigrants. Father watched the prow of the scaly broad-beamed vessel splash in the sea. Her decks were packed with people. Thousands of male heads in derbies. Thousands of female heads covered with shawls. It was a rag ship with a million dark eyes staring at him. Father, a normally resolute person, suddenly foundered in his soul. A weird despair seized him. The wind came up, the sky had turned overcast, and the great ocean began to tumble and break upon itself as if made of slabs of granite and sliding terraces of slate. He watched the ship till he could see it no longer." (p. 13). 
The anarchist Emma Goldman had been deported. The beautiful and passionate Evelyn Nesbit had lost her looks and fallen into obscurity. And Harry K. Thaw, having obtained his release from the insane asylum, marched annually at Newport in the Armistice Day parade ${ }^{437}$. (p. 320)

A ausência de um enredo unificado confere um caráter de panorama de época ao romance ${ }^{438}$, que é reforçado pelo claro enquadramento temporal da narrativa (virada do século XIX para o século XX até o início da Primeira Guerra Mundial) ${ }^{439}$. Esse foi um período de relativa tranquilidade no campo econômico: "De meados dos anos 1890 à Grande Guerra, a orquestra econômica mundial tocou no tom maior da prosperidade, em vez de no tom menor da depressão ${ }^{440}$ ". No entanto, havia sinais do iminente colapso do quadro social que culminou em conflitos, e mesmo revoluções (1917), em várias partes do mundo:

...violentas greves quase gerais em Belfast (1907), Liverpool (1911) e Dublin (1913), uma greve geral na Suécia (1908) e até a "Semana trágica" em Barcelona (1909).

Em 1912, o primeiro-ministro britânico Asquith, a despeito da proverbial impassibilidade do gentleman inglês, chorou ao anunciar a retirada do governo diante de uma greve geral de mineiros de carvão.

Tais fenômenos não devem ser subestimados. Embora os contemporâneos não soubessem o que viria depois, sentiam frequentemente, nesses últimos tempos que precederam a guerra, a sensação de que a terra tremia como sob os choques sísmicos que precedem os terremotos. Esses foram anos em que, sobre os hotéis Ritz e as casas de campo, pairavam no ar prenúncios de violência.

437 "A anarquista Emma Goldman foi deportada. A bela e apaixonada Evelyn Nesbit perdeu sua beleza e caiu no anonimato. E Harry K. Thaw, liberado do asilo para doentes mentais, marchava anualmente em Newport, na parada do Dia do Armistício.” (p. 277).

${ }^{438}$ É justamente a ausência dessa visão ampla de um período que Doctorow vê como maior defeito da adaptação para o cinema do romance feita por Milos Forman (Ragtime, 1981): "He has an idea for films that makes them equivalent to a short story: one person, and one person's revelation, and one person's fate - that's all. That was the real censorship of that film, that my friend Forman didn't see the larger canvas." (DOCTOROW. In: MORRIS, op. cit., p. 115). A versão de Robert Altman estava prevista para ter mais de 6 horas de duração.

${ }^{439}$ Outro elemento que confere um enquadramento temporal à narrativa pode ser observado no período de ascensão e declínio do gênero musical Ragtime, cuja popularidade começa a crescer no final do século XIX e decai por volta de 1917, ano da morte de Scott Joplin. Retomarei esse tema adiante.

${ }^{440}$ HOBSBAWN, Eric. A Era dos Impérios (1875-1914). São Paulo: Paz e Terra, 2011, p. 81. 
Sublinhavam a instabilidade e a fragilidade da ordem política da belle époque ${ }^{441}$.

A dialética da riqueza e da exclusão que venho aqui mostrando no romance captura bem esse período de prosperidade e ostentação no ápice da pirâmide social (o luxo e as excentricidades dos ricos são amplamente retratados nas figuras de Harry K. Thaw, Stanford White, J. P. Morgan, Mrs. Stuyvesant Fish) e revolta premente na base.

O distanciamento narrativo aumenta quando são narradas ações dos personagens fictícios, o que confirma a tendência desse romance de, ao tentar conferir ares de verdade a dados ficcionais, confundir os limites entre ficção e história. No episódio da guerra de Coalhouse Walker Jr pela restituição de seu Ford Modelo $\mathrm{T}$ podemos observar a preocupação do narrador em afirmar seu distanciamento do fato narrado, o qual ele relata quase que em modo jornalístico, como vemos nos trechos abaixo:

Here, given subsequent events, it is important to mention what little is known about Coalhouse Walker $\mathrm{Jr}^{442}$. (p. 183)

It was widely reported when he was achieving his notoriety that Coalhouse Walker had never exhausted the peaceful and legal means of redress before taking the law into his own hands ${ }^{443}$. (p. 183)

It is known also that Coalhouse Walker consulted a black attorney in $\mathrm{Harlem}^{444}$. (p. 184)

\footnotetext{
${ }^{441}$ Idem, p. 177.

442 "Em vista dos acontecimentos subsequentes, é importante mencionar o pouco que se sabe de Coalhouse Walker Jr." (p. 160).

443 "Foi amplamente registrado, quando alcançou notoriedade, que Coalhouse Walker não esgotara os meios pacíficos e legais de obter indenização antes de tomar a lei nas próprias mãos." (p. 160).

444 “Sabe-se também que Coalhouse Walker consultou um advogado negro do Harlem.” (p. 161).
} 
It is known too that Coalhouse made a preliminary attempt to see the matter through as his own counsel ${ }^{445}$. (p. 185)

O uso da voz passiva (em destaque) cria um efeito de distanciamento. O uso dessas estruturas nas sentenças acima cria a sensação de que as informações sobre os passos de Coalhouse Walker Jr são de conhecimento geral e trazem um ar de veracidade jornalística aos fatos reportados.

Efeito semelhante de distanciamento acontece com o tratamento que o narrador dá ao relato das ações de outro personagem ficcional, o Irmão Mais Novo:

Our knowledge of this clandestine history comes to us by Younger Brother's own hand. He kept a diary from the day of his arrival in Harlem to the day of his death in Mexico a little more than a year later ${ }^{446}$. (p. 244)

We know from Brother's journal that the actual plan had been to make Morgan a prisoner in his own home. (p. 268)

O uso do diário como fonte de informações sobre o destino do personagem cria um efeito de distanciamento e traz um ar de veracidade ao relato. É como se o narrador se afastasse para apenas reportar as informações como elas aparecem no diário, nas palavras do próprio personagem. O mesmo efeito é buscado na passagem a seguir, mas agora com um personagem histórico, em episódio mencionado anteriormente:

He was upside down over Broadway, the year was 1914, and the Archduke Franz Ferdinand was reported to have been assassinated. It was at this moment that an image composed itself in Houdini's mind. The image was of a small boy looking at himself in the shiny brass headlamp of an automobile.

445 "É sabido também que Coalhouse Walker fez uma tentativa preliminar de resolver o caso sozinho." (p. 161).

446 "O conhecimento desta história clandestina chegou-nos através da pena do Irmão Mais Novo, que redigiu um diário desde o dia de sua chegada ao Harlem até sua morte no México, pouco mais de um ano depois." (p. 212). 
We have the account of this odd event from the magician's private, unpublished papers ${ }^{447}$. (p. 316)

$\mathrm{O}$ efeito de distanciamento almejado nos trechos acima confere à narração um aspecto de crônica histórica. Ao usar o recurso ficcional de atribuir o conhecimento sobre os passos dos personagens à leitura de diários e escritos privados e o recurso da voz passiva para criar a sensação de que o conteúdo reportado é sabido não apenas do narrador, sustenta-se a impressão de que não há onisciência do narrador, mas apenas o relato de fatos. Como vimos nas palavras do próprio autor, esse procedimento tem caráter irônico e, ao criar uma imitação de discurso historiográfico dentro de uma obra de fícção, produz uma zona de indefinição que coloca em evidência tanto a pretensão de verdade do relato historiográfico quanto o potencial da ficção de iluminar verdades históricas. Esse embaraço é produtivo, pois, creio, não quer provar inúteis os dois modos narrativos em jogo: quer, antes, evidenciar o caráter narrativo da própria História, que pode se manifestar em formas de narrar diferentes. Em tempos em que se pensa em "fim da história”, qualquer tentativa de pensar a História como uma narrativa aberta à mudança merece atenção.

O efeito de distanciamento e isolamento da matéria histórica também é observado no recorrente emprego de epítetos na evocação de personagens reais. Assim esses personagens têm suas qualidades e defeitos reduzidos ${ }^{448} \mathrm{a}$ um aspecto, geralmente de caráter anedótico ou rotineiro o suficiente para não o individualizar e mantê-lo no espaço do domínio público. Podemos verificar esse fato nos trechos a seguir:

\footnotetext{
447 "Estava de cabeça para baixo sobre a Broadway, em 1914, ano em que o Arquiduque Francisco Ferdinando fora assassinado. Naquele momento, uma imagem estampou-se na mente de Houdini: um meninozinho mirando-lhe no brilhante farol de um automóvel.” (p. 274).

448 Em um primeiro momento, uma vez que alguns desses personagens vão ser melhor caracterizados durante a narrativa, mas não ao ponto de alcançar profundidade psicológica suficiente para individualizá-los e separá-los da massa humana que constitui a torrente de figuras no romance.
} 
Emma Goldman, the revolutionary.

$*$

Emma Goldman, the anarchist revolutionary.

$*$

...red Emma Goldman, the anarchist, was in New York.

*

The anarchist Emma Goldman had been deported.

*

Harry Houdini, the escape artist.

$*$

The car's owner was Harry Houdini, the famous escape artist.

$*$

She turned out to be the eminent Lavinia Warren, the widow of

General Tom Thumb, the most famous midget of all.

In New York City the papers were full of the shooting of the famous architect Stanford White by Harry K. Thaw, eccentric scion of a coke and railroad fortune. Harry K. Thaw was the husband of Evelyn Nesbit, the celebrated beauty who had once been Stanford White's mistress.

Big Bill Haywood, the most famous Wobbly of them all.

At this time in history Jacob Riis, a tireless newspaper reporter and reformer, wrote about the need of housing for the poor.

$*$

the morose novelist Theodore Dreiser

$*$

Booker T. Washington was at this time the most famous Negro in the country.

$*$

Sitting in the car was the Archduke Franz Ferdinand, heir to the Austro-Hungarian throne. 
O uso dessas expressões qualificativas é comum em livros didáticos e em textos para um público não especializado. Alguns deles poderiam facilmente ser transpostos para esses livros, como: "heir to the Austro-Hungarian throne", "famous architect", "the anarchist", "the escape artist", "the famous escape artist". Mas a maioria dessas expressões são imitações cômicas do tipo de expressão qualificativa usada em textos didáticos e não existiriam fora de uma obra de ficção como Ragtime. Vejamos alguns exemplos disso: "the revolutionary", "the anarchist revolutionary", "the widow of General Tom Thumb - the most famous midget of all", "eccentric scion of a coke and railroad fortune", "the celebrated beauty who had once been Stanford White's mistress", "the most famous Wobbly of them all", "the morose novelist".

A imitação cômica desse tipo de expressão funciona como um exercício crítico que usa o ridículo para indicar o processo de redução e simplificação implícito nesse procedimento didático comum em textos não especializados sobre história e cultura.

Vários personagens históricos recebem caracterização cômica ou são colocados em situações ridículas. Em quase todos os casos, isso ocorre com personagens ricos, como Harry K. Thaw, J. P. Morgan e Henry Ford. O emprego do cômico como sublinhador do absurdo da ostentação em meio à pobreza generalizada pode ser visto na passagem que descreve o jantar planejado por J. P. Morgan como uma reunião da elite que, para ele, encarna o poder na América. A expectativa de Morgan com esse jantar é gerar um poderoso acúmulo de energia produtiva no encontro da elite de seu tempo. O ridículo da ideia é acompanhado do ridículo dos personagens nela envolvidos. O jantar se desenrola contra as expectativas de Morgan, de maneira a revelar o ridículo como característica compartilhada pela elite ali reunida. Vejamos como isso se dá no romance:

Once, years before, he had arranged a dinner party at his residence on Madison Avenue in which his guests were the dozen most powerful men in America besides himself. He was hoping the collected energy of their minds might buckle the walls of his home. Rockefeller startled him with the news that he was chronically constipated and did a lot of his thinking on the toilet. Carnegie dozed over his brandy. Harriman uttered inanities. 
Gathered in this one room the business elite could think of nothing to say. How they appalled him. How his heart quaked. He heard through his brain the electric winds of an empty universe. He ordered the servants to place garlands of laurel on every pate and crown. Without exception the dozen most powerful men in America looked like horse's asses. But the pomposity that had accrued with their wealth persuaded them that perhaps these ridiculous vines held some significance. No one of the women thought to laugh. They were hags. They sat on their large draped behinds, breasts drooping under their décolletage. Not an ounce of wit among them. Not a light in their eyes. They were the loyal wives of great men and the hard pull of rampant achievement had sucked the life out of their flesh. Revealing nothing of his feelings Morgan hid behind his fierce and doughty expression. A photographer was summoned to make a picture. There was a flash — the solemn moment was recorded ${ }^{449}$. (p. 140)

Sob o manto de seriedade e sucesso da parte mais próspera da América, revela-se o risível.

O mesmo tratamento cômico é dado a Henry Ford ${ }^{450}$, que, em diálogo com Morgan, surpreende este último com uma explicação pouco eloquente sobre a genialidade:

Well then, Ford continued, I happened to pick up a little book. It was called An Eastern Fakir's Eternal Wisdom, publish by the Franklin Novelty Company of Philadelphia, Pennsylvania. And

\footnotetext{
449 "Certa vez, anos antes, organizara um jantar em sua residência de Madison Avenue, no qual os convidados eram os 12 homens mais poderosos da América, além dele próprio. Esperava que as energias reunidas de tantas inteligências abalassem as paredes de sua casa. Rockefeller espantou-o com a notícia de que sofria de constipação crônica e fazia grande parte de seus raciocínios no banheiro, Carnegie cochilou sobre o próprio brandy. Harriman murmurou idiotices. Reunida naquela sala, a elite dos negócios não sabia o que dizer. Morgan ficou abismado, coração apertado. Ouvia mentalmente os ventos elétricos de um universo vazio. Ordenou aos criados que colocassem coroas de louros em todas as cabeças. Sem exceção, a dúzia dos homens mais poderosos da América ficou com cara de idiota. Mas a pomposidade que aumentara com a riqueza persuadiu-os de que talvez aquelas coroas ridículas tivessem algum significado. Nem uma só das mulheres pensou em rir. Eram verdadeiras bruxas. Sentadas sobre seus grandes traseiros drapeados, seios caídos sob o decote, não possuíam um grama de espírito. Nem uma centelha no olhar. Eram leais esposas de grandes homens e o forte impulso de destacadas realizações havialhes sugado a vida do corpo. Nada revelando dos seus sentimentos, Morgan escondeu-se por detrás de sua feroz expressão. Um fotógrafo foi convocado para tirar uma foto. Houve um clarão e o solene momento ficou registrado.” (pp. 124-125).

${ }^{450}$ A caracterização cômica de Ford começa quando ele entra na casa de Morgan e observa o ambiente: "There were fancy paintings hanging behind glass in heavy frames - pictures of yellowish soulful-looking people with golden haloes. He guessed nobody had their pictures made in those days who wasn't a saint" (pp. 145-146).
} 
in this book, which cost me just twenty-five cents, I found everything I needed to set my mind to rest. Reincarnation is the only belief I hold, Mr. Morgan. I explain my genius this waysome of us have just lived more times than others. So you see, what you have spent on scholars and traveled around the world to find, I already knew. And I'll tell you something, in thanks for the eats, I'm going to lend that book to you. Why, you don't have to fuss with all these Latiny things, he said waving his arm, you don't have to pick the garbage pails of Europe and build steamboats to sail the Nile just to find out something that you can get in the mail order for two bits! $!^{451}$ (p. 152)

A meritocracia e a teoria de Morgan sobre o caráter excepcional das mentes que decidem o destino das massas são colocados em xeque pelo aspecto vazio e ridículo das supostas "inteligências" reunidas no banquete da elite. A única coisa que sustenta o poder dessas figuras é a própria riqueza, e é ela o único elemento de distinção desse grupo: "Mas a pomposidade que aumentara com a riqueza persuadiu-os de que talvez aquelas coroas ridículas tivessem algum significado".

Além da caracterização cômica de personagens históricos observamos em Ragtime momentos em que fatos históricos recebem interpretações cômicas, como acontece na passagem em que o narrador comenta as mudanças nos Estados Unidos trazidas pela posse do presidente William Howard Taft:

Back home a momentous change was coming over the United States. There was a new President, William Howard Taft, and he took office weighing three hundred and thirty-two pounds. All over the country men began to look at themselves. They were used to drinking great quantities of beer. They customarily devoured loaves of bread and ate prodigiously of the sausage meats of poured offal that lay on the lunch counters of the saloons. The august Pierpont Morgan would routinely consume seven- and eight-course dinners. He ate breakfast of steaks and chops, eggs, pancakes, broiled fish, rolls and butter, fresh fruit and cream. The consumption of food was a sacrament of success. A man who

\footnotetext{
451 "Muito bem, prosseguiu Ford. Encontrei por acaso um livrinho intitulado An Eastern Pakir's Eternal Wisdom, publicado pela Franklin Novelty Company de Filadélfia, Pensilvânia. E nesse livro, que me custou apenas 25 centavos, achei tudo que precisava para me tranquilizar. A reencarnação é a minha única crença, Sr. Morgan. Explico assim o meu gênio: alguns viveram mais vidas que outros. Assim, o que o senhor gastou com eruditos e viajando ao redor do mundo eu já sabia. E vou the dizer algo em agradecimento pelo almoço: empresto-lhe o livro. Ora, não precisa se preocupar com todos esses latins, falou, gesticulando. Não precisa remexer as latas de lixo europeias e construir navios para percorrer o Nilo só para descobrir algo que pode obter encomendando por dois dólares pelo reembolso postal!” (pp. 134-135).
} 
carried a great stomach before him was thought to be in his prime. Women went into hospitals to die of bursts bladders, collapsed lungs, overtaxed hearts and meningitis of the spine. There was a heavy traffic to the spas and sulphur springs, where the purgative was valued as an inducement to the appetite. America was a great farting country. All this began to change when Taft moved into the White House. His accession to the one mythic office in the American imagination weighed everyone down. His great figure immediately expressed the apotheosis of that style of man. Thereafter fashion would go the other way and only poor people would be stout ${ }^{452}$. (pp. 82-83)

O parágrafo que começa com o anúncio de uma importante mudança nos Estados Unidos se desenrola de maneira a concluir que a América estava, com Taft, deixando de ser um "great farting country", uma vez que a moda mudou e ser gordo deixou de ser sinal de prosperidade. O tom sério criado no início do parágrafo "Back home a momentous change was coming over the United States" é invertido pelo tom cômico da continuação do texto.

A caracterização cômica dos ricos em Ragtime atende a um imperativo crítico. Há um pouco do espírito da sátira horaciana nesse uso do ridículo como veículo de crítica e motor de mudanças de costumes.

Em artigo recente, Chris Hedges aponta como uma grave falta a nossa inabilidade em apreender a patologia da riqueza. Na contramão da reinante celebração da riqueza e do sucesso como elementos de distinção, ele propõe que busquemos uma leitura mais verdadeira da maneira como os ricos concebem o mundo ao seu redor:

\footnotetext{
452 "Uma importantíssima transformação processava-se nos Estados Unidos. Fora eleito um novo presidente, William Howard Taft, que assumiu o cargo pesando 162 quilos. No país inteiro os homens começaram a se observar. Estavam habituados a beber grande quantidade de cerveja. Devoravam pães habitualmente e comiam uma prodigiosa quantidade de linguiça recheada com sobras deixadas nos balcões dos bares. O augusto Pierpont Morgan consumia rotineiramente jantares de sete, oito pratos. Ao café-da-manhã comia bife, costeleta de porco, ovos, panquecas, peixe cozido, pãezinhos com manteiga, frutas frescas e creme. $\mathrm{O}$ consumo de alimento era o sacramento do sucesso. O homem que ostentava um ventre volumoso encontrava-se no ápice da saúde. As mulheres internavam-se em hospitais onde morriam de ruptura da bexiga, falência do pulmão, coração sobrecarregado e meningite da medula espinhal. Havia muito movimento rumo às fontes sulfurosas, onde o purgativo era apreciado como um incentivo ao apetite. Toda a América era um grande arroto. Tudo isso começou a mudar quando Taft se instalou na Casa Branca. Sua ascensão ao único posto mítico na imaginação americana caiu pesadamente sobre todos. Seu grande vulto expressou de imediato a apoteose daquele estilo de homem. Daí em diante a moda seguiria caminho inverso e só os pobres seriam gordos". (pp. 76-77).
} 
The inability to grasp the pathology of our oligarchic rulers is one of our gravest faults. We have been blinded to the depravity of our ruling elite by the relentless propaganda of public relations firms that work on behalf of corporations and the rich. Compliant politicians, clueless entertainers and our vapid, corporate-funded popular culture, which holds up the rich as leaders to emulate and assures us that through diligence and hard work we can join them, keep us from seeing the $\operatorname{truth}^{453}$.

A patologia dos ricos é expressa na teoria que J. P. Morgan expõe a Henry Ford na tentativa de convencê-lo a juntar-se à "Pirâmide", "o mais exclusivo clube dos Estados Unidos":

All mammals reproduce in the same way and share the same designs of self-nourishment, with digestive and circulatory systems that are recognizable the same, and they enjoy the same senses. Obviously this is not to say all mammals have interchangeable parts, as your automobiles. But shared design is what allows taxonomists to classify mammals as mammals. And within a species - man, for example - the rules of nature operate so that our individual differences occur on the basis of our similarity. So that individuation may be compared to a pyramid in that it is only achieved by the placement of the top stone ${ }^{454}$. (p. 147)

Assim, a desigualdade é explicada por Morgan como um fato biológico.

Há, no romance uma variação de tom. Decorosamente, o narrador emprega um tom cômico para retratar ações e ideias baixas realizadas e pensadas por personagens ridículos - geralmente, eles são ricos (Harry K. Thaw é o exemplo mais óbvio desse procedimento) - e um tom elevado para retratar cenas carregadas de dramaticidade e

\footnotetext{
${ }^{453}$ HEDGES, Chris. Let's Get This Class War Started. Truthout, Monday, 21 October 2013. http://www.truth-out.org/opinion/item/19527-lets-get-this-class-war-started (Acesso em 29/12/2013).

454 “Todos os mamíferos reproduzem-se da mesma maneira e compartilham dos mesmos impulsos de autonutrição, com sistemas digestivo e circulatório perceptivelmente semelhantes, e gozam dos mesmos sentidos. É óbvio que isto não significa que todos os mamíferos tenham partes intercambiáveis, como os seus automóveis. Mas o plano geral é o que permite aos taxonomistas classificar os mamíferos como tais. E dentro de uma espécie - a humana, por exemplo - as regras da natureza operam de modo que nossas diferenças individuais baseiam-se na nossa similaridade. Assim, a individualização pode ser comparada a uma pirâmide, no sentido de que só é alcançada graças à colocação da pedra mais alta". (pp. 129-130).
} 
seriedade. Essa variação do tom trágico ao cômico pode ser facilmente percebida se compararmos as passagens acima com as duas a seguir:

One afternoon she took her finished work to the loft on Stanton Street. The owner invited her into his office. He looked at the piece goods carefully and said she had done well. He counted out the money, adding a dollar more that she deserved. This he explained was because she was such a good-looking woman. He smiled. He touched Mameh's breast. Mameh fled, taking the dollar. The next time the same thing happened. She told Tateh she was doing more work. She became accustomed to the hands of her employer. One day with two weeks' rent due she let the man have his way on a cutting table. He kissed her face and tasted the salt of her tears ${ }^{455}$. (p. 16)

$* * *$

Every season of the year wagons came through the streets and picked bodies of derelicts. Late at night old ladies in babushkas came to the morgue looking for their husbands and sons. Corpses lay on tables of galvanized iron. From the bottom of each table a drainpipe extended to the floor. Around the rim of the table was a culvert. And into the culvert ran the water sprayed constantly over each body from an overhead faucet. The faces of the dead were upturned into the streams of water that poured over them like the irrepressible mechanism in death of their own tears ${ }^{456}$. (p. 15)

Como vimos, esse romance é rico em variações. A dialética da riqueza e da exclusão é também comunicada nessa variação de tons, que grava a depravada ostentação dos ricos com a marca do ridículo e registra a miséria com as cores do trágico.

455 "Uma tarde levou o trabalho acabado ao sótão da Stanton Street. O proprietário convidou-a a entrar no escritório e, examinando cuidadosamente a mercadoria, disse que ela costurava muito bem. Contando o dinheiro, acrescentou um dólar à quantia, explicando que era por Mameh ser tão bonita. Sorriu. Tocou no seio de Mameh. Mameh fugiu, levando o dólar. Na vez seguinte aconteceu a mesma coisa: Ela disse a Tateh que estava trabalhando mais e habituou-se às mãos do patrão. Certo dia, estando o aluguel atrasado em duas semanas, entregou-se ao homem sobre uma mesa de corte. Ele beijou-a no rosto, sentindo o gosto salgado de suas lágrimas." (pp. 2223).

456 "Em todas as estações do ano, as carroças percorriam as ruas, recolhendo corpos abandonados. Tarde da noite, velhas de lenço na cabeça entravam no necrotério em busca de maridos e filhos. Os corpos jaziam em mesas de ferro galvanizado. Do extremo de cada, descia um cano até o piso. Ao redor da mesa havia uma calha. E nela corria a água que jorrava constantemente sobre cada corpo, saindo de uma torneira acima da mesa. Os rostos dos mortos estavam voltados para aqueles jorros d'água que os cobria como o irreprimível mecanismo de suas próprias lágrimas." (p. 21). 
Um aspecto formal de Ragtime que certamente captura a atenção do leitor logo ao primeiro contato com a obra é a linguagem com que a história é contada. As frases curtas, as repetições de pronomes e de estruturas descritivas do inglês - como there was (cento e seis ocorrências no romance) e there were (sessenta ocorrências) - chamam a atenção por sua especificidade e pelo ritmo que impõem à leitura. Na obra de Doctorow, esse livro se destaca, sobretudo se comparado a The Book of Daniel e Loon Lake, pela uniformidade da linguagem, como ressalta Jameson: "Nesse romance em especial Doctorow se impôs um princípio rigoroso de seleção, segundo o qual apenas sentenças declarativas simples

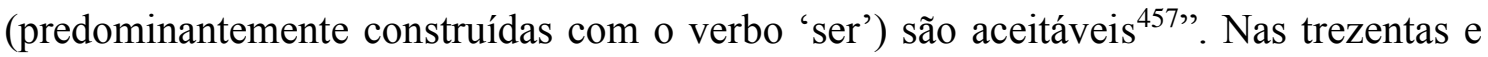
vinte páginas de romance (na edição aqui usada) o verbo ser aparece cerca de duas mil vezes (entre ocorrências de was - mais de mil e quinhentas - e de were - mais de quinhentas ${ }^{458}$ )

Jameson busca na linguística um modelo para descrever a forma e os efeitos do tipo de frase usada em Ragtime. Em estudo sobre os paradigmas temporais do verbo francês, Émile Benveniste distingue dois planos de enunciação: o da história e o do discurso. Para o linguista francês, na enunciação histórica ocorre a "apresentação dos fatos sobrevindos a um certo momento do tempo, sem nenhuma intervenção do locutor na narrativa ${ }^{459}$ ". Já o plano do discurso acontece quando há uma interferência do historiador (ou do narrador, no caso do romance) para julgar os acontecimentos referidos $^{460}$. Em ensaio, citado por Jameson e Benveniste, sobre o romance L'étranger, de Albert Camus, Jean-Paul Sartre estuda o uso das frases nesse romance como a sedimentação em linguagem do sentimento de absurdo presente nessa obra de Camus. Diante do "absurdo", a explicação se paralisa. Assim, para Sartre, L'étranger não é um

${ }^{457}$ JAMESON, Fredric. Pós-Modernismo - A lógica Cultural do Capitalismo Tardio. São Paulo: Ática, 1996, p. 51.

${ }^{458}$ Esses números foram obtidos por meio do uso de ferramentas de pesquisa aplicadas em um arquivo que contém o texto integral do romance.

${ }^{459}$ BENVENISTE, Émile. Problemas de linguística geral I. Campinas: Pontes, 1995, p. 262.

${ }^{460}$ Idem, p. 267. 
livro que explica, uma vez que "o homem absurdo não explica; ele descreve ${ }^{461}$ ". A noção de causalidade foi extirpada desse mundo ${ }^{462}$. Isso se reflete na organização das frases no romance, que são ilhas ${ }^{463}$, "sem arestas, fechadas em si mesmas e separadas das frases seguintes por um nada ${ }^{464}$ ", Para Sartre, nesse romance

$\mathrm{O}$ romancista prefere a uma narrativa organizada este cintilar de pequenos brilhos sem amanhã dos quais cada um é uma volúpia (...) Sua frase não pertence ao universo do discurso, não tem nem ramificações, nem prolongamentos, nem estrutura interior ${ }^{465}$.

Para Jameson, as frases em Ragtime criam em inglês efeitos semelhantes aos alcançados em francês por Camus em L'étranger ${ }^{466}$. Tal efeito parece ocorrer, por exemplo, nas passagens a seguir:

At this time in history Jacob Riis, a tireless newspaper reporter and reformer, wrote about the need of housing for the poor. They lived too many to a room. There was no sanitation. The streets reeked of shit. Children died of mild colds or slight rashes. Children died on beds made from two kitchen chairs pushed together $^{467}$. (p. 16)

The immigrants were reminded of home. They went into the streets and were somehow absorbed in the tenements. They were despised by New Yorkers. They were filthy and illiterate. They stank of fish and garlic. They had running sores. They had no honor and worked for next to nothing. They stole. They drank. They raped their own daughters. They killed each other casually $^{468}$. (p. 14)

\footnotetext{
${ }^{461}$ SARTRE, Jean-Paul. Situações I - crítica literária. São Paulo: CosacNaify, 2005, p. 121.

${ }^{462}$ Idem, p. 132.

${ }^{463}$ Idem, p. 129.

${ }^{464}$ Idem, p. 129.

${ }^{465}$ Idem, p. 131.

${ }^{466}$ JAMESON, op. cit., p. 51.
}

467 “A esta altura da história, Jacob Riis, incansável jornalista e reformador, escreveu sobre a necessidade de moradia para os pobres. Viviam aglomerados numa só peça. Não possuíam sanitários. As ruas cheiravam a excremento. Crianças morriam de simples resfriados ou de leves erupções de pele. Morriam em camas improvisadas com duas cadeiras de cozinha." (p. 23).

468 "Tudo lembrava-lhes a pátria. Enveredando pelas ruas eram absorvidos pelos cortiços, não se sabia como. Os nova-iorquinos desprezavam-nos. Eram sujos e analfabetos. Cheiravam a peixe e 
At this time businessmen were discovering the profit in practical jokes and parlor magic tricks. There were exploding cigars, rubber roses for the lapel that squirted water, boxes of sneezing powder, telescopes that left black eyes, exploding card deck, sound bladders for placing under chair cushions, glass paperweight with winter scenes in which snow fell when you shook them, exploding matches, punchboard, little lead liberty bells and statues of liberty, magic rings, exploding fountain pens, books that told you the meaning of dreams, rubber Egyptian belly dancers, exploding watches, exploding eggs ${ }^{469}$. (p. 132)

Nos trechos acima, as frases estão organizadas em um padrão cumulativo, em que as informações são acrescentadas em progressão de intensidade (como nos dois primeiros exemplos) ou em forma de lista (como no último exemplo).

Em alguns momentos da narrativa, as frases aparecem organizadas em um padrão de ironia, em que há uma indefinição entre discurso indireto livre e discurso indireto que não permite saber ao certo se a voz naquele ponto da narração é do narrador ou de um personagem. No trecho a seguir, as partes destacadas em negrito trazem essa indefinição da voz narrativa:

As it happened he had been standing on the quarter-deck observing Peary soundly scold one of the Esquimo men who had not done his assigned chore properly. Then Peary shuffled back along the deck, passing Father and saying to him They're children and they have to be treated like children. Father tended to agree with this view, for it suggested a consensus. He recalled an observation made in the Philippines ten years before where he had fought under General Leonard F. Wood against the Moro guerrillas. Our little brown brothers have to be taught a lesson, a staff officer had said, sticking a campaign pin in a map. There was no question that the Eskimos were primitives. They were

alho. Ostentavam feridas abertas. Não tinham amor-próprio e trabalhavam por quase nada. Roubavam. Bebiam. Violentavam as próprias filhas. Matavam-se tranquilamente uns aos outros" (pp. 20-21).

469“"A essa altura, os homens de negócios começavam a descobrir o que havia de lucro nas brincadeiras e mágicas de salão. Havia charutos explosivos, rosas de borracha para a lapela que esguichavam água, caixas de pó que provocava espirros, telescópios que deixavam o olho preto, baralhos que explodiam, jogos de manivela, sininhos e estátuas da liberdade, anéis mágicos, canetas explosivas, livros que revelavam o significado dos sonhos, dançarinas com o ventre de borracha, relógios explosivos, ovos idem.” (p. 118). 
affectionate, gentle, emotional, trustworthy and full of pranks. They loved to laugh and sing ${ }^{470}$. (p. 74)

Há, nos trechos em negrito, a eclosão de células de ironia que funcionam como comentários à matéria narrada.

Um último padrão de organização das frases em Ragtime ocorre em períodos em que há uma espécie de condensação de ideias dispostas em forma de um silogismo no qual as premissas e a conclusão são colocadas em um único plano, sem conjunções que explicitem a relação de causa e consequência entre os elementos do raciocínio. Vejamos alguns exemplos:

There were screams. Evelyn fainted. She had been a well-known artist's model at the age of fifteen. Her underclothes were white. Her husband habitually whipped her. She happened once to meet Emma Goldman, the revolutionary. Goldman lashed her with her tongue. Apparently there were Negroes. There were immigrants. And though the newspapers called the shooting the Crime of the Century, Goldman knew it was only 1906 and there were ninetyfour years to $\mathrm{go}^{471}$. (p. 5)

Esse trecho funciona como uma espécie de sumário de ideias e relações, algumas das quais serão desenvolvidas na narrativa. Dispostas em forma de períodos simples, as relações entre Evelyn, Emma Goldman, a existência de negros e imigrantes e a espetacularização do assassinato de Stanford White por Harry K. Thaw não são dadas,

470 "Encontrava-se no tombadilho superior, observando Peary censurar vigorosamente um dos esquimós que não havia cumprido corretamente sua tarefa. Em seguida, o comandante percorreu, arrastando os pés, o tombadilho, e ao passar por Papai murmurou: São crianças e têm que ser tratados como tais. Papai inclinava-se a concordar com este ponto de vista, pois sugeria um consenso: recordava-se de uma observação feita nas Filipinas, dez anos atrás, quando lutara sob o comando do general Leonard F. Wood contra os guerrilheiros Moros. Nossos irmãozinhos mulatos precisam aprender uma lição, dissera um oficial graduado, fixando no mapa um alfinete. Ninguém punha em dúvida que os esquimós eram primitivos. Mostravam-se afetuosos, gentis, emotivos, dignos de confiança e cheios de brincadeiras. Adoravam rir e cantar.” (pp. 69-70).

471 "Ouviram-se gritos. Evelyn desmaiou. Ela foi modelo de um artista com a idade de 15 anos. Usava roupas de baixo brancas. Era habitualmente açoitada pelo marido. Certa vez encontrou por acaso Emma Goldman, a revolucionária. Goldman agrediu-a verbalmente. Aparentemente os negros existiam. E também os imigrantes. E, embora os jornais chamassem ao assassinato $\mathrm{O}$ Crime do Século, Goldman sabia que se estava apenas em 1906 e que restavam ainda 94 anos ela frente." (p. 13). 
apenas insinuadas pelo encadeamento das frases sem conectores. Essas conexões operam por justaposição.

Algo parecido ocorre na passagem

One hundred Negroes a year were lynched. One hundred miners were burned alive. One hundred children were mutilated. There seemed to be quotas for these things. There seemed to be quotas for death by starvation. There were oil trusts and banking trusts and railroad trusts and beef trusts and steel trusts ${ }^{472}$. (p. 40)

Esse longo parágrafo, analisado acima, é rico em justaposições e ilustra bem o procedimento aqui referido. A relação entre os negros linchados, os mineiros queimados vivos, as crianças mutiladas, as mortes por inanição, os trustes e os bailes temáticos de pobreza oferecidos pelos ricos não é estabelecida sintaticamente, por meio do uso de conjunções ou outros recursos de coesão, mas sim insinuada pela justaposição desses elementos.

Esses exemplos mostram que as frases em Ragtime não são sempre ilhas, como as de Camus em L'étranger, segundo Sartre. Há, na linguagem de Ragtime, uma dialética entre o impulso de criar relações e de figurar um quadro histórico e social mais amplo e a dificuldade de se realizar esse projeto por meio da linguagem e da lógica da fragmentação e da compartimentalização, que impedem as articulações e emperram a representação. A linguagem de Ragtime, com suas falhas e indefinições, constitui um sintoma instrutivo do impasse formal do romance histórico contemporâneo.

No entanto, conexões são feitas, como tentei mostrar ao longo do capítulo, por meio de vários procedimentos estéticos: a variação de tom (cômico para os ricos, trágico para as cenas de miséria), que compõe, com a dialética da riqueza e da exclusão, um retrato da divisão de classes nos Estados Unidos; a sintaxe cumulativa, com o seu poder de ênfase por acumulação ou gradação; a justaposição dos opostos, que ocorre quando são justapostas cenas, parágrafos ou frases dentro do mesmo parágrafo; a eclosão de células de ironia.

472 "Uma centena de negros era linchada anualmente. Uma centena de mineiros era queimada viva. Uma centena de crianças era mutilada. Aparentemente havia quotas para tais coisas. Quotas para a morte pela fome. Havia também trustes de petróleo, trustes bancários, trustes de estrada de ferro, trustes da carne e truste do aço.” (p. 42). 


\section{"As if history were no more than a tune on a player piano": a metáfora musical no romance}

O gênero musical conhecido como ragtime foi muito popular na virada do século até $1917^{473}$, ano da morte de Scott Joplin, o mais célebre compositor do gênero. O período de maior popularidade do ragtime coincide com o intervalo de tempo abrangido no romance, conferindo a este um enquadramento temporal. Doctorow confirma sua intenção de usar esse período de tempo - a era do ragtime - como um princípio construtivo do romance: "With Ragtime I stumbled on the idea that a period of time was as good a constructive principle as a sense of place $^{474 \text { " }}$

Não há em Ragtime um fio narrativo que costure os variados enredos paralelos. $\mathrm{O}$ episódio Coalhouse Walker, apesar de ocupar bastante espaço na narrativa e de mobilizar vários personagens, não consegue unificar todos os enredos paralelos em uma linha narrativa. Tateh e Houdini, dois importantes personagens no romance não participam da história de Coalhouse Walker, por exemplo. Além disso, Walker só aparece na metade do romance ${ }^{475}$ e sua história divide espaço com narrativas que ocupam lugar significativo no romance, como os de Tateh, Houdini e Evelyn Nesbit.

Essa característica da narração em Ragtime suscitou comparações com comédias musicais dos anos 30 e com obras de ragtime:

Ragtime (1975) is like those musical comedy entertainments turned out by MGM and RKO in the 1930s, with Busby Berkeley settings, and perhaps held together by Fred Astaire or Gene Kelly a little later. Such entertainments had a story line that existed

${ }^{473}$ ALBINO, C.; LIMA, S. R. A., C. O percurso histórico da improvisação no ragtime e no choro. Per Musi, Belo Horizonte, n.23, 2011, p.74.

${ }^{474}$ CROWN, Sarah. EL Doctorow: "I don't have a style, but the books do". The Guardian, London, 23 de Janeiro de 2010, Culture, Books. Disponível em <http://www.guardian.co.uk/books/2010/jan/23/el-doctorow-homer-and-lamgley>. (Acesso em: 01 de Junho de 2013).

${ }^{475}$ Precisamente, no capítulo 21 (o romance tem 40 capítulo), na página 157 da edição em inglês aqui usada. 
solely as cement for the musical numbers (...) Like a ragtime musical bit, the novel turns on its variations ${ }^{476}$.

A história de Coalhouse Walker entra no enredo de Ragtime a partir da metade do livro para forjar uma coerência entre as partes do romance, que é ajudada pela metáfora musical anunciada na epígrafe e só retomada explicitamente no último parágrafo do livro. A epígrafe traz um aviso para o intérprete que Scott Joplin escrevia nas folhas com suas composições: "Do not play this piece fast / It is never right to play Ragtime fast". Como epígrafe do livro, o aviso de Joplin serve ao leitor de recomendação para resistir à precipitação de informações e às variações repentinas de um enredo paralelo para outro que, somadas ao estilo de escrita em jorro de frases que caracteriza a linguagem de Ragtime, criam no romance um ritmo constante e rígido que lembra o de uma música tocada por uma pianola ("player piano", no romance) ${ }^{477}$.

Há poucas referências diretas ao gênero musical ragtime no romance. A palavra é mencionada no livro apenas quatro vezes, se contarmos a epígrafe. Em uma dessas ocasiões, Coalhouse Walker, em sua primeira visita à família branca (Mamãe, Papai, Irmão Mais Novo e Menino) que abriga sua noiva e filho, executa no piano dois ragtimes célebres compostos por Scott Joplin: "Wall Street Rag" e "The Maple Leaf". O único membro da família que conhece esse gênero musical é o Irmão Mais Novo, que entrou em contato com o ragtime durante um período de vida boêmia em Nova York. Aqui há uma imprecisão histórica, uma vez que a narrativa começa em 1906 e, por essa época, o ragtime já era um dos gêneros musicais mais populares nos Estados Unidos, também entre os brancos ${ }^{478}$.

\footnotetext{
${ }^{476}$ KARL, Frederick R. On Ragtime's Variations. In: BLOOM, Harold. E.L. Doctorow's Ragtime. Philadelphia: Chelsea House, 2004, p. 64-65.

477 Doctorow declara, em entrevista, sua intenção com a narrativa em Ragtime: "I was very deliberately concentrating on the narrative element. I wanted a really relentless narrative, full of ongoing energy. I wanted to recover that really marvelous tool for a novelist, the sense of motion" (DOCTOROW. In: MORRIS, op. cit., p. 2).

478 "Historical ragtime was pioneered by blacks and initially resisted by the Victorian musical establishment. But after 1900 ragtime lost its association with black musicians and became a "white" music by national adoption. Hence black sounds entered the American mainstream in whiteface, as it were. James T. Maher writes: 'The straight line from plantation music to the earliest recorded jazz (1917) runs through ragtime: the impact of Negro syncopation is the major force in the Americanization of our popular music.' After 1917 ragtime was replaced by jazz and Tin Pan Alley and gradually lost its status as the queen of popular music" (OSTENDORF, Berndt.
} 
Narrativamente, no entanto, a ignorância da família WASP em relação ao ragtime, e, por extensão, à força da cultura negra na formação social americana, simboliza a invisibilidade do negro ${ }^{479}$ para a América branca, que é ironicamente referida no primeiro parágrafo do romance (“There were no negroes, there were no immigrants”) e desmentida no mesmo parágrafo: “Apparently there were Negroes. There were immigrants". O destaque em itálico dado ou verbo to be no segundo trecho enfatiza uma verdade que dará origem a tensões e conflitos desenvolvidos no enredo.

As reações da família ao ragtime trazido por Coalhouse revelam inclinações que serão confirmadas no decorrer da narrativa. O personagem Papai ignora esse gênero musical e demonstra sua distância e preconceito contra a cultura negra americana ao perguntar a Coalhouse se ele conhecia alguma canção "coon ${ }^{480}$ ". A reação de Coalhouse à pergunta de Papai antecipa sua postura de insubmissão:

But the pianist responded with a tense shake of the head. Coon songs are made for minstrel shows, he said. White men sing them in blackface. There was another silence. The black man looked at the ceiling. Well, he said, it appears as Miss Sarah will not be able to receive me. He turned abruptly and walked through the hall to the kitchen. The family followed him $^{481}$. (p. 160)

A palavra "ragtime" reaparece no último parágrafo do romance, confirmando o enquadramento temporal da narrativa, cujo fim coincide com o fim da "era do ragtime": "E a essa altura, a era do ragtime esgotara-se com o pesado arquejar da máquina, como se a história não passasse de uma canção tocada numa pianola”. Uma nota pessimista é dada pela imagem da história como uma "canção tocada numa pianola". A pianola, sendo um instrumento que toca músicas automaticamente, prescinde da ação humana e mesmo

On the Musical World. In: BLOOM, Harold. E.L. Doctorow's Ragtime. Philadelphia: Chelsea House, 2004, p. 87).

${ }^{479}$ Tema de grande importância para a literatura americana, como pode ser conferido em obras como The Invisible man, de Ralph Ellison, Native Son, de Richard Wright, ou na poesia de Langston Hughes, para citar apenas alguns autores que exploraram esse tema.

${ }^{480}$ Maneira ofensiva de se referir a pessoas negras.

481 "Mas o pianista respondeu com um tenso menear de cabeça. Tais canções eram feitas para espetáculos ambulantes, replicou. Brancos cantavam-nas com o rosto pintado de preto. Seguiu-se um silêncio. O negro fixou o teto. Bem, parece que a Srta. Sarah não poderá me receber, falou. Voltando-se bruscamente, atravessou o hall em direção à cozinha. A família seguiu-o" (p. 141). 
impede qualquer modificação do andamento de sua programação. Se a história fosse uma canção tocada numa pianola, ela se desenrolaria deterministicamente, alheia à agência humana. O dinamismo do enredo desse romance, a dialética de classes nele retratada e as variações de tom da narrativa não corroboram tão visão determinista da história. Uma sutileza sintática impede o fechamento de todas as possibilidades históricas nesse romance que transita entre o pessimismo e a esperança: o uso de uma estrutura subjuntiva, "as if history were", que sugere a comparação como uma possibilidade, não como uma certeza.

No último parágrafo do livro reaparece Tateh, o que confirma a centralidade desse personagem para a narrativa. $\mathrm{O}$ ex-operário e ex-socialista é agora um grande empresário do cinema e expõe uma imagem que tem para uma cena de filme:

One morning Tateh looked out the window of his study and saw the three children sitting on the lawn. Behind them on the sidewalk was a tricycle. They were talking and sunning themselves. His daughter, with dark hair, his tow-headed stepson and his legal responsibility, the schwartze child. He suddenly had an idea for a film. A bunch of children who were pals, white black, fat thin, rich poor, all kinds, mischievous little urchins who would have funny adventures in their own neighborhood, a society of ragamuffins, like all of us, a gang, getting into trouble and getting out again. Actually not one movie but several were made of this vision. ${ }^{482}$. (pp. 319-320)

A visão de Tateh de uma sociedade de crianças esfarrapas ${ }^{483}$ que, unidas pelo sentimento de grupo ("like all of us, a gang"), superam barreiras raciais e sociais ("white black, fat thin, rich poor, all kinds ") para juntos viverem aventuras divertidas oferece um

482 "Certa manhã, Tateh, espiando pela janela do estúdio, viu as três crianças sentadas no gramado. Atrás delas, na calçada, uni triciclo. Conversavam e tornavam sol. Sua filha, cabelos negros, o enteado de cabelos curtos, por quem era legalmente responsável e a criança negra. Súbito, ocorreu-lhe uma ideia para um filme. Um bando de crianças amigas, brancas negras, gordas magras, ricas pobres, de todos os tipos, diabretes travessos que viveriam engraçadas aventuras em seu bairro, uma sociedade de maltrapilhos como todos nós, uma gangue, envolvendo-se em encrencas e delas se livrando. Na verdade, desta visão resultou não um filme, mas vários." (p. 277).

${ }^{483}$ Ragamuffins, no original. A palavra contém uma alusão a ragtime. Vejamos duas definições da palavra: Merriam-Webster: a ragged often disreputable person; especially: a poorly clothed often dirty child (http://www.merriam-webster.com/dictionary/ragamuffin); Cambridge: (oldfashioned informal) - a dirty untidy child in torn clothes (http://dictionary.cambridge.org/dictionary/british/ragamuffin?q=ragamuffins\#ragamuffin_3) 
contraponto idílico aos conflitos presentes em toda a narrativa e que atingem o clímax com o fim trágico da rebelião de Coalhouse Walker. Que essa visão tenha sido replicada em muitos outros filmes e que o veículo para essa imagem conciliadora de uma sociedade de esfarrapados vivendo histórias divertidas seja o cinema ${ }^{484}$ diz muito do começo de uma era pautada pela máquina ${ }^{485}$ : "And by that time the era of Ragtime had run out, with the heavy breath of the machine".

Para Slavoj Zizek, o cinema hoje é a mais pervertida das artes, pois ele não nos dá o que desejamos, ele nos ensina o que desejar ${ }^{486}$. O ex-socialista Tateh também entende a função ideológica do cinema:

In the movie films, he said, we only look at what is there already. Life shines on the shadow screen, as from the darkness of one's mind. It is a big business. People want to know what is happening to them. For a few pennies they sit and see their selves in movement, running, racing in motorcars, fighting and, forgive me, embracing one another. This is most important today, in this country, where everybody is so new ${ }^{487}$. (p. 256)

\footnotetext{
${ }^{484}$ Meio de expressão que, salvo exceções, se presta habitualmente, de D. W. Griffith em diante, ao treinamento ideológico do público. Para entender o impacto estético e ideológico do surgimento do cinema, conferir o ensaio "A obra de arte na era de sua reprodutibilidade Técnica" (BENJAMIN, Walter. In: Obras escolhidas: magia e técnica, arte e política. São Paulo: Brasiliense, 1987, p.165-193).

${ }^{485}$ O tema do crescimento do domínio da máquina não é desenvolvido plenamente no romance, mas é um elemento importante, no livro, para caracterizar o mundo que sucede a "era do ragtime". Esse tema está no centro da trajetória de Harry Houdini, artista que, como Busten Keaton e Charlie Chaplin, tentou se adaptar às novas tecnologias do entretenimento. $\mathrm{O}$ embaraço que essa adaptação infligia a um artista de vaudeville como Houdini e a associação dessas novas tecnologias ao grande capital, representado no romance pelo desdém das classes altas à arte do mágico, podem ser lidos na passagem a seguir: "People who did not respond to hi art profoundly distressed Houdini. He had come to realize they were invariably of the upper classes. Always they broke through the pretense of his life and made him feel foolish. Houdini had high inchoate ambition and every development in technology made him restless. On the shabby confines of a stage he would create wonder and awe. Meanwhile men were beginning to take planes into the air, or race automobiles that went sixty miles an hour." (p. 31).
}

${ }^{486}$ DVD “The Pervert's Guide To Cinema” (2006), dirigido por Sophie Fiennes.

487 "Nos filmes, dizia ele, olhamos apenas o que já existe. A vida cintila na tela como que emergindo das sombras de nossa mente. É um grande negócio. As pessoas querem saber o que acontece com elas. Em troca de algumas moedas sentam-se para se ver em movimento, correndo, disparando em automóveis, lutando e, perdoem-me, beijando-se. Isto tem muita importância hoje, neste país, onde todos são tão novos. Existe muita necessidade de compreender”. (p. 222). 
Uma concepção parecida do cinema como instrumento de treinamento ideológico pode ser visto nessa passagem de City of God (2000):

...e gradualmente aperfeiçoaram um sistema de arquétipos sociais dentro dos quais encaixavam fisicamente pessoas adequadas que batizaram de atores e encontraram um lugar sob o sol da Califórnia para produzir numa base industrial organizada estes filmes corporativos que, qualquer que fosse a época em que se passassem, contemporânea, histórica ou futurista, demonstravam ao público que os via, agora sentado no escuro em teatros palacianos construídos exatamente para aquele propósito, que os filmes eram uma forma de vida à qual a vida devia aspirar, como hoje ela mostra todo sinal de estar fazendo ${ }^{488}$.

Assim, Ragtime se fecha com uma referência a uma forma de expressão artística, o cinema, que é, hoje, o meio dominante de se contar histórias. Doctorow, em entrevista, se mostra avesso a esse meio de expressão ${ }^{489}$ e crítico da aceleração que esse meio impõe à percepção humana ${ }^{490}$. Tal crítica é compartilhada pelo narrador do romance City of God, que propõe uma comparação entre romances e filmes:

A ficção vai por toda parte, dentro, fora, ela pára, ela segue, sua ação pode ser mental. Não é também pressionada pelo tempo. $\mathrm{O}$ filme é pressionado pelo tempo, ele nunca rumina, ele mostra o lado de fora da vida, mostra comportamento. Tende ao raciocínio moral mais simples. Filmes produzidos por Hollywood são lineares. A simplificação narrativa de uma realidade de consequências moralmente complexas é sempre a sobra de um filme inspirado por um livro. Os romances podem fazer qualquer coisa nos horrores obscuros da consciência. Filmes fazem closeups, entradas de carros, lugares, caçadas e explosões ${ }^{491}$.

${ }^{488}$ DOCTOROW, E. L. Deus, um fracasso amoroso. São Paulo, Rio de Janeiro: Editora Record, 2003, p. 306.

489 "I have misgivings about film. I think it involves regression somehow." (DOCTOROW. In: MORRIS, op. cit., p. 40).

490 "The rhythms of perception are shot. That's why the theater is in such difficulty today, because people watch actors standing on the stage for fifteen or twenty minutes doing exposition and they get restless." (DOCTOROW. In: MORRIS, op. cit., p. 10).

${ }^{491}$ DOCTOROW, E. L. Deus, um fracasso amoroso. São Paulo, Rio de Janeiro: Editora Record, 2003, p. 277. 
Com o anúncio do que está por vir com o domínio da tecnologia, o romance se encerra - junto com a era do ragtime, lembremos - como se dentro do enquadramento temporal em que a narrativa se desenrola sobrevivesse uma forma de temporalidade diferente de nossa. A epígrafe do livro, de Scott Joplin, sugere essa temporalidade, a nossa distância em relação a ela e a necessidade de ajustar a nossa percepção acelerada à narrativa de Ragtime: "Do not play this piece fast. It is never right to play Ragtime fast". 


\section{Capítulo 3}

\section{"The strength of no illusions": a organização do pessimismo em Homer $\mathcal{E}$ Langley.}

Embora o progresso do século XX seja inegável, as previsões não sugerem um ascenso contínuo, mas a possibilidade, talvez até a iminência, de alguma catástrofe: outra e mais letal guerra mundial, um desastre ecológico, uma tecnologia cujo triunfo torne o mundo inabitável para a espécie humana, ou qualquer outra forma atual que o pesadelo possa revestir. A experiência nos ensinou, em nosso século, a viver na expectativa do apocalipse. (HOBSBAWN, Eric. A Era dos Impérios. São Paulo: Paz e Terra, 2011, p. 504) 


\section{Os "eremitas do Harlem"}

Homer \& Langley (2009) recria a história de dois irmãos que se entrincheiraram em sua mansão na Quinta Avenida, em Nova York, e lá viveram por décadas ${ }^{492}$. O isolamento dos irmãos Homer e Langley Collyer rendeu-lhes o apelido de "eremitas do Harlem $^{493}$ " e atraiu a curiosidade da cidade, alimentada também pelo hábito de Langley de recolher e guardar objetos diversos achados nas ruas de Nova York. Em suas excursões noturnas pelas ruas do bairro, ele recolhia objetos que, acumulados na casa de quatro andares, alcançaram um volume aproximado de 180 toneladas $^{494}$, fato que determinou a decisão da prefeitura de demolir a mansão após a morte dos irmãos. Entre os objetos encontrados na casa estão um Ford Modelo T, um bote ${ }^{495}$ e quatorze pianos ${ }^{496}$.

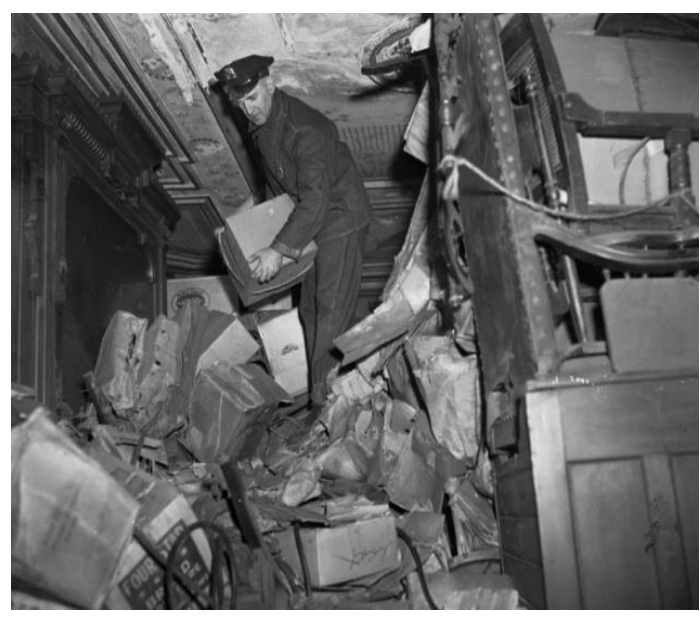

\footnotetext{
${ }^{492}$ Homer (morto aos 65 anos) e Langley (morto aos 61 anos) viveram na casa de número 2078 da Quinta Avenida de 1909 até 1947, ano em que morreram (LIDZ, Franz. Ghosty Men - The Strange but True Story of the Collyer Brothers, New York's Greatest Hoarders. New York: Bloomsbury, 2003).

${ }^{493}$ LIDZ, Franz. Ghosty Men - The Strange but True Story of the Collyer Brothers, New York's Greatest Hoarders. New York: Bloomsbury, 2003, p. 1.

${ }^{494}$ Idem, p. 9.

${ }^{495}$ Idem, p. 13.

${ }^{496}$ Idem, p. 15.
} 


\section{Policiais retiram objetos da casa dos Collyer. As buscas por Langley levaram semanas http://www.nydailynews.com/new-york/collyer-brothers-brownstone- gallery-1.1187698?pmSlide $=5$}

De origem rica, os irmãos Collyer estudaram na Universidade de Colúmbia e tiveram uma infância próspera, vivendo com os pais na mesma casa da Quinta Avenida que ficaria célebre. Com a morte dos pais, Homer e Langley começaram a se afastar do mundo. Homer, cego e paralisado, passava a maior parte do tempo na cama, enquanto seu irmão cuidava das batalhas da família com a prefeitura, fornecedores de serviços e vizinhança.

Enquanto o bairro em que moravam, o Harlem, transformava-se com a desvalorização e a chegada de famílias negras de baixa renda ${ }^{497}$, os irmãos se fechavam na mansão, que ia se afastando dos tempos de luxo e prosperidade da virada do século. No romance, o processo de decadência da casa Collyer tem como marco inicial a dispensa do mordomo (primeiro dos funcionários da família a sair de cena) e como marco final a queda do candelabro de cristais, símbolo dos tempos de fortuna da casa que despenca do teto sem aviso.

Em 1947, os dois irmãos foram encontrados mortos em sua residência, depois de semanas de buscas entre as pilhas de jornais e objetos acumulados pelas décadas de andanças de Langley. Após denúncia anônima de que Homer estaria morto, bombeiros entraram na casa e enfrentaram as toneladas de objetos ali guardados até acharem o corpo. Impossibilitado de sair da cama e sem poder contar com a ajuda do irmão - já morto, como se constataria mais tarde - Homer morreu de inanição. Os bombeiros continuaram a retirar objetos da casa e, após semanas de serviço, encontraram o corpo de Langley embaixo de uma pilha de itens de sua "coleção". Ele fora esmagado por toneladas de papel ao acionar uma das muitas armadilhas contra invasores que ele mesmo instalara. A

497 "No blacks lived on the Collyer's block in Harlem when the doctor [o pai] left. But by the time Susie [a mãe] died in 1929, black Harlem had almost reached 110th Street, its Central Park boundary. And the boys began their retreat into a hermitage of their own creation" (LIDZ, op. cit., p. 55). "But though waves of transformation swept over Harlem, they would never again live anywhere else. They stayed while the house crumbled around them. They turned into reclusive hermits who barely acknowledged the passing of time. They remained locked in a turn-of-thecentury time warp through both world wars, the Great Depression and the devolution of Harlem from an exclusive white suburb to a poor black ghetto" (LIDZ, op. cit., p. 45). 
partir de então, o nome Collyer passou a ser associado à compulsão por acumular objetos e deu nome a uma síndrome - a "síndrome dos irmãos Collyer".

Os dois haviam se tornado celebridades involuntárias e a cidade se mobilizara em busca de Langley, desaparecido há semanas ${ }^{498}$.

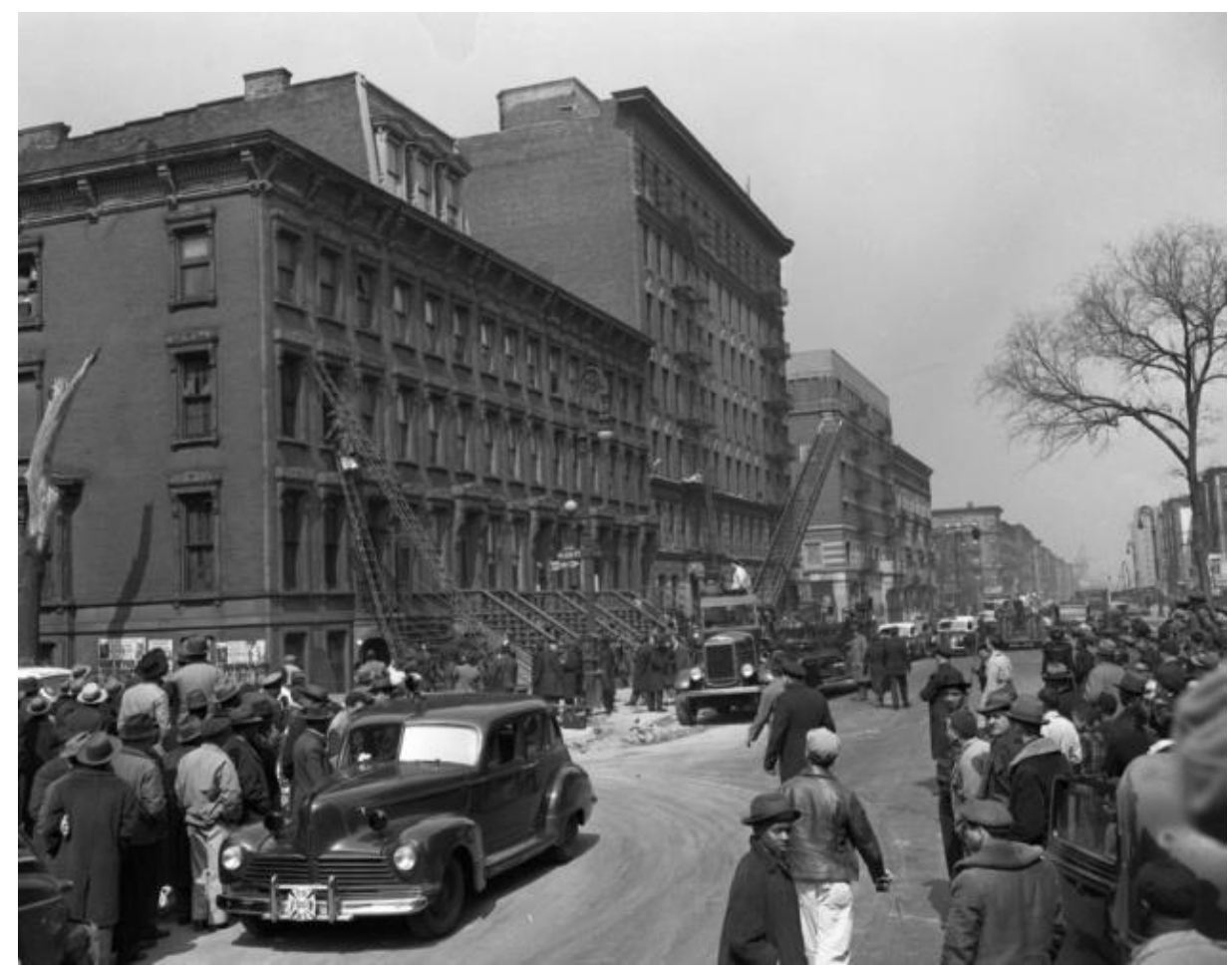

Público acompanha buscas na casa dos Collyer.

http://www.nydailynews.com/new-york/collyer-brothers-brownstone-gallery1.1187698?pmSlide $=13$

Outro fato inusitado da história dos Collyer é que, vivendo no coração da civilização industrial, os dois ermitões renunciaram a serviços considerados essenciais à

\footnotetext{
${ }^{498} \mathrm{O}$ escritor Howard Fast observa, em artigo de jornal publicado na época, o fascínio dos seus contemporâneos pela história dos Collyer: "Durante 1947 - quando a Doutrina Americana foi lançada por Harry Truman, quando as pessoas tremiam diante do pensamento de guerra atômica, quando o Comitê de Atividades Não-americanas de Thomas-Rankin se tornou a inquisição moderna -, dois irmãos morreram em uma casa no Harlem e o povo americano quase esquece de tudo mais, e cada vez que abria seu jornal era para saber das últimas sobre Langley Collyer..." (FAST, Howard. The World of Langley Collyer. In: The New Masses, April 22, 1947, p. 6). Tradução minha.
} 
vida em grandes centros urbanos, como o telefone (desligado em 1917 ${ }^{499}$ ) e o fornecimento de gás e eletricidade, dispensado desde $1928^{500}$. No romance, o contraste entre a vida rústica dos irmãos e a moderna metrópole na qual vivem ganha ênfase pelo deslocamento da casa para a frente do Central Park, região muito mais valorizada da Quinta Avenida do que o endereço verdadeiro dos Collyer ${ }^{501}$. Sem luz, gás, telefone e repleta de objetos recolhidos da rua por um de seus excêntricos moradores, a casa fictícia enfrenta a cidade com mais ousadia que a verdadeira.

No romance, o contraste entre a localização nobre da casa e o que ela guarda em seu interior gera desconfiança nos moradores elegantes da vizinhança, como nos relata Homer, o narrador: “As damas, por sua vez, pareciam cautelosas em relação a nós, ou talvez à nossa residência, Fifth Avenue por fora e aspirante a armazém por dentro ${ }^{502}$ " (p. $63)$.

Pode-se fazer uma análise do caso Collyer a partir de uma leitura da acumulação como imperativo e, ao mesmo tempo, deficiência do modo de produção capitalista. Stallabrass, em seu admiravelmente ousado livro Gargantua: manufactured mass culture, defende que erros e contingências podem fornecer solo para a construção de críticas. Para esse olhar que procura sentido em objetos tradicionalmente descartados como de poucaou de nenhuma - relevância crítica, bugs de computador, fotografias amadoras, efeitos acidentais da sobrescrita em grafites e o lixo surpreendem como fonte de agudas

\footnotetext{
${ }^{499}$ LIDZ, op. cit., p. 19.

${ }^{500}$ Idem.

501 A casa verdadeira fica na esquina da rua $128^{\circ}$ com a Quinta Avenida, a cerca de dezoito quarteirões do Central Park, que termina na rua $110^{\circ}$.

502 Todas as citações em português são da tradução publicada em 2011, (Homer \& Langley. Rio de Janeiro: Record, 2011) de Roberto Muggiati, e vêm acompanhadas da numeração de páginas dessa edição. Em nota de rodapé, disponibilizarei o texto original de cada citação do romance, que não trazem identificação de página porque foram tiradas de uma versão eletrônica do livro, a qual não é numerada em páginas mas sim em "posições". No original: These ladies for their part seemed wary of us, or perhaps of our residence, Fifth Avenue on the outside and something of an aspiring warehouse on the inside.
} 
percepções sobre a sociedade na qual figuram como acidente. Assim "o lixo, como o grafite, é algo que as pessoas fazem coletivamente, e não tão inadvertidamente ${ }^{503}$ ”. Stallabrass destaca que há uma ligação entre lixo e mercadoria como há uma ligação entre produção e consumo ${ }^{504}$. Dessa forma, tem-se que mercadorias são lixo $\operatorname{adiado}^{505}$. O aparente absurdo de se buscar significado no livro (projeto que motiva o impulso acumulador de Langley no romance) pode, se levado a sério, iluminar o real absurdo da situação na qual o lixo é produzido ${ }^{506}$.

Homer e Langley ocupam sua casa com aquilo que é rejeitado como lixo pela sociedade. Assim, eles mantêm em casa rastros do excedente e do descartado, como uma lembrança do destino da mercadoria e do caráter negativo da acumulação. É como excedente que a prosperidade econômica dos Estados Unidos durante os períodos de guerra entra no "museu" Collyer:

Ao final da guerra, tendo a força produtiva da economia americana gerado um excedente de tudo aquilo de que todo soldado necessitaria, havíamos juntado além das máscaras antigas, um estoque de material militar suficiente para equipar um exército só nosso $^{507}$. (p. 118)

No "detalhe" do excedente de material bélico revela-se um dos principais quando não o principal - motivos da sanha americana por guerras: o impulso produtivo que elas alimentam. Sintomaticamente, Condoleezza Rice, Secretária de Estado do governo de George W. Bush, difunde, em suas aulas em Yale, a tese de que o Estados Unidos passa por fases de expansão econômica durantes períodos de guerra.

\footnotetext{
${ }^{503}$ STALLABRASS, Julian. Gargantua: manufactured mass culture. London; New York: Verso, 1996, p. 172.

${ }^{504}$ Idem.

${ }^{505}$ Idem.

506، The meaning of trash would seem to lie in a surreal absurdity, but by taking it seriously, this very quality may come to illuminate the real absurdity of the situation in which it is produced". (Idem, p. 173).

${ }^{507}$ No original: By the time of war's end, the productive might of the American economy having overproduced everything a soldier would need, we'd collected, besides the gas masks, enough military surplus to outfit an army of our own.
} 
O impulso da acumulação foi fatal para os Collyer. Howard Fast, em artigo publicado após a descoberta do corpo de Langley, afirma para aqueles que estavam procurando respostas para a bizarra história desses dois ermitões que a explicação para o episódio "não é figurativa, mas literal ${ }^{508 "}$ "

Property fell on him and squashed him like a bug. He was crawling among the property, and it got him. If he didn't die at once, he very likely starved to death. (...) But they barricade themselves with possessions, tons and tons of possessions, yet it avails them not. And at last the possessions fall on Langley Collyer and squash him like a bug 509 .

Esse viés interpretativo é rico em possibilidades críticas e também sinaliza o teor político desse romance. No entanto, por uma questão de unidade argumentativa da tese, concentrarei a análise dessa obra na interação entre história e forma na construção ficcional. Mostrarei, nas páginas seguintes, a forte presença da História na narrativa e como a forma desse romance difere significativamente das outras duas obras estudadas nos capítulos anteriores e marca dois momentos distintos da produção artística de E. L. Doctorow e da história americana.

\section{Levados pelos ventos da história}

Doctorow toma outras liberdades com relação aos dados históricos sobre a vida dos irmãos Collyer. No romance, Homer e Langley vivem até a década de 80, o que permite que se trace, por meio da narração de Homer, um panorama do século XX

\footnotetext{
${ }^{508}$ FAST, op. cit.

${ }^{509}$ Idem.
} 
americano. O livro chegou a ser descrito como "uma viagem caleidoscópica através dos Estados Unidos do século XX"510.

Eventos históricos vão se sucedendo cronologicamente na narração. Praticamente não há página nesse livro em que o narrador não esteja remetendo o leitor a algum desses eventos ou comentando suas consequências na rotina da residência Collyer. A seguir, listo alguns dos fatos históricos presentes na narrativa, na ordem em que aparecem, a fim de mostrar a abundância desses fatos no romance, sua sucessão cronológica no enredo e a maneira como se entrelaçam com a vida dos Collyer, invadindo seu refúgio:

Chegada de levas de imigrantes europeus no começo do século: alguns deles trabalham na casa. Homer se envolve com a Húngara Julia. Siobhan, uma senhora irlandesa, também empregada da casa, vê com desconfiança o crescente domínio de Julia sobre Homer. Logo, um anel da mãe de Homer e Langley sumirá, Julia será revelada a culpada pelo sumiço da relíquia de família e demitida pelo roubo. A passagem, de cerca de quatorze páginas, sobre a presença dos imigrantes na casa termina com uma reflexão de Langley a respeito da política de imigração do país:

...são as hordas imigrantes que mantêm este país vivo, as ondas deles que chegam ano após ano. Tínhamos de demiti-la, mas na verdade ela demonstra o gênio de nossa política de imigração. Quem acredita mais nos Estados Unidos do que as pessoas que descem a prancha do navio e beijam a terra? ${ }^{511}$ (p. 44).

Aqui, é explícito o movimento, constante nesse romance, de transpor experiências privadas da casa Collyer para um quadro social mais amplo. A reflexão de Langley sobre o papel dos imigrantes na formação social americana nasce do contato com dois representantes desse grupo. Novamente, vemos a intersecção de planos ontológicos ser esboçada, como vimos acontecer em The Book of Daniel. No entanto, as formas como essa intersecção se dá difere nos dois romances: no de 1971, essas conexões são derivadas de elaboradas teias de relações que promovem a intersecção, de maneira complexa e

\footnotetext{
${ }^{510}$ CIABATTARI, Jane. Amid The Rubbish, Doctorow Finds Meaning. NPR.org, September 04, 2009. http://www.npr.org/templates/story/story.php?storyId=112447772.

${ }^{511}$ No original: We had to fire her, Homer, she was too smart to trust. But I'll give you this: it is the immigrant hordes who keep this country alive, the waves of them arriving year after year. We had to fire the girl, but in fact she demonstrates the genius of our national immigration policy. Who believes in America more than the people who run down the gangplank and kiss the ground?
} 
figurativamente produtiva, entre a vida de Daniel e a história política dos Estados Unidos; em Homer \& Langley, romance formalmente tímido em relação a The Book of Daniel, essas relações são elaboradas na superfície do texto, no nível mesmo do diálogo entre os personagens, que é uma forma de transposição do real para a ficção figurativamente fraca em comparação às construções em que, na célebre formulação de Antônio Cândido, "o externo vira interno".

Primeira Guerra Mundial: Langley atua como soldado e traz sequelas de ataques com gás mostarda. Como veremos adiante, as guerras do século XX têm papel importante na constituição do cansaço existencial dos irmãos Collyer. É a partir de sua experiência de guerra que Langley passa a adotar uma "vida mental iconoclasta ${ }^{512 "}$. Essa disposição em relevar o lado obscuro dos mitos de sucesso da história norte-americana é exercitada por Langley na ocasião da Parada do Armistício, evento que reuniu um exército de patriotas em desfile pela Quinta Avenida, endereço dos Collyer. Homer relata a reação de seu irmão à passagem da população em festa:

Quando aconteceu a Parada do Armistício, e eu podia sentir a empolgação da cidade, pessoas passando rapidamente por nossa casa, os carros se arrastando, buzinas tocando, e, através de tudo aquilo, os acordes das músicas de marcha militar, ouvi de Langley, como que antifonicamente, suas experiências. (p. 29)

\footnotetext{
512“Havia muito, Langley tinha reciclado sua amargura pós-guerra transformando-a numa vida mental iconoclasta" (p. 90). No original: Langley had long since reworked his post-war bitterness into an iconoclastic life of the mind.
} 


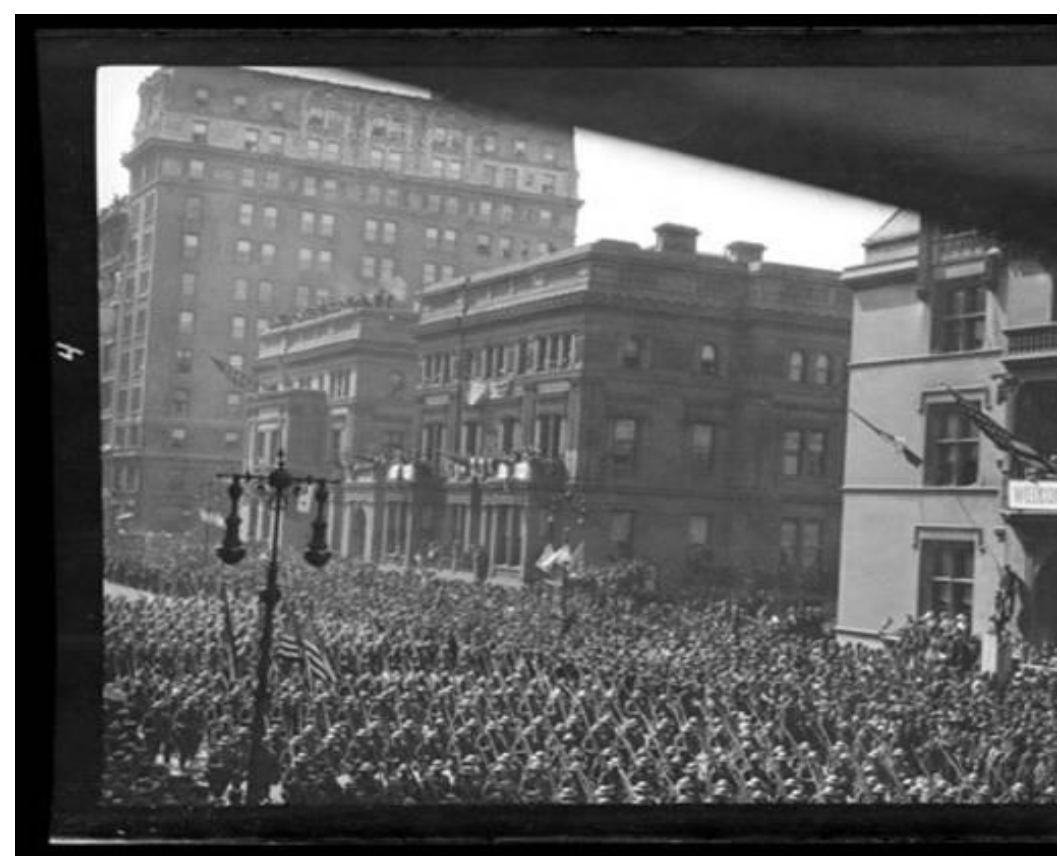

ArmisticeDayparade, NewYorkCity, 1918.

\section{Northern Arizona University. Cline Library (http://archive.library.nau.edu/cdm/ref/collection/cpa/id/68620)}

Os ruídos de euforia vindos da rua se transformam em trilha sonora para o relato dos horrores da guerra feito por Langley. Essa sobreposição de cenários (a euforia da marcha da vitória e os horrores vividos nas trincheiras) é paradigmática do movimento da narrativa de contrapor versões da história.

Fim do cinema mudo: Homer, com a ajuda de uma assistente que sussurra para ele as cenas dos filmes, trabalha como pianista em um cinema na 3th avenida. Com a chegada do cinema falado, a função de pianista de acompanhamento de filmes é extinta e ele é demitido (p. 51). No romance, os avanços tecnológicos são, em geral, percebidos como algo negativo pelos irmãos, o que dá força ao caráter utópico do projeto de separação tentado por eles. Fredric Jameson aponta a relação entre a recusa à naturalização da ideia de que desenvolvimento tecnológico é sinônimo de "progresso" 513 e o esboço de projetos de "desconexão" do capitalismo:

\footnotetext{
513 A relação entre progresso e barbárie (estudada, por exemplo, por Walter Benjamin) não permite que tal palavra seja usada sem lembrar-se dos possíveis significados que ela esconde. Aqui, ela é tomada com o significado que o senso comum lhe confere, como sinônimo de avanço, de melhoria geral das condições de vida. O uso das aspas é para lembrar as conotações negativas
} 
Mas parece claro que a maior barreira a qualquer tipo de política de controle da tecnologia é justamente a nossa mais profunda crença (verdadeira ou falsa) de que a inovação tecnológica é irreversível. Isso pode então ser visto como uma alegoria da "desconexão" no nível do político: tentar imaginar uma comunidade sem computadores - ou carros ou aviões - é tentar conceber a viabilidade de se separar do global $^{514}$.

Prohibition era: num dos estabelecimentos ilegais que serviam bebidas durante a Lei Seca (anos 20), os irmãos conhecem o mafioso Vicent (p. 54), que retornará adiante na narrativa para interferir na rotina da casa Collyer.

Red Scare e deportação de imigrantes militantes de esquerda. Langley se envolve com Anna, a "radical" russa, e a acompanha em atividades políticas. Quando ele a pede em casamento, ela responde ao pedido com um discurso sobre o casamento como uma forma legalizada de prostituição. Homer pergunta ao irmão que tipo de "radical" Anna é, ao que ele responde:

Que diferença faz? É algum tipo de comunista-socialistaanarquista-anarco-sindicalista. A não ser que você seja um deles, não sabe dizer exatamente o que são. Quando não estão jogando bombas, estão ocupados se dividindo em facções ${ }^{515}$. (p. 66)

O pedido de casamento e depois a fala sobre a filiação política de Anna revelam que Langley, apesar do caráter oposicionista geral de suas ideias, não se alinha a nenhum dos grupos de esquerda. A questão das diversas posições de esquerda e do eventual choque entre elas ${ }^{516}$ é apenas referida nessa passagem do romance, mas é tratada lembremos - com profundidade em The Book of Daniel, e ganha espaço em Ragtime, no

dessa palavra, como em "A ferrovia e a expansão para o oeste levaram o progresso para aquela parte dos Estados Unidos", na qual "progresso" significa o extermínio das populações nativas.

${ }^{514}$ JAMESON, Fredric. A cultura do dinheiro. Petrópolis: Vozes, 2001. p. 36.

${ }^{515}$ No original: Who knows, he said. What difference does it make? She's some kind of Socialistanarchist-anarcho-syndicalist-Communist. Unless you're one of them you can't tell exactly what any of them are. When they're not throwing bombs they're busy splitting into factions.

${ }^{516}$ Antônio Cândido (militante do partido socialista), ao comentar sua surpresa ao saber que Graciliano Ramos (militante do partido comunista) o tinha escolhido para escrever a introdução de suas obras completas, diz que "quem é de esquerda sabe que as tensões mais graves estão dentro da esquerda. A esquerda às vezes se odeia mais do que odeia a direita". (Depoimento de Antônio Cândido no Simpósio Graciliano Ramos - 75 anos do livro "Angústia" - FFLCH - 20 de Setembro de 2011 - http://www.youtube.com/watch?v=p3r-dY-0Ows). 
contato e no atrito entre o socialista Tateh e a anarquista Emma Goldman. A tensão entre esses dois grupos emerge durante uma palestra de Emma para socialistas, o que a obriga a clamar por conciliação em nome da própria sobrevivência dos grupos: "Comrades, let us disagree, of course, but not by losing our decorum to the extent that the police may have an excuse to interrupt us".

Jazz e Harlem Renaissance: além do panorama histórico, a trajetória dos Collyer pelo século XX americano desenha também um panorama cultural dos Estados Unidos, como também acontece em Ragtime. Harold Robileaux, um músico negro originário de New Orleans (como seu sobrenome francês sugere), vai morar com sua tia, empregada dos Collyer, na casa dos ermitões. Ela traz o jazz e a efervescência cultural do Harlem nos anos 20 e 30 para dentro da casa. Logo, a atmosfera de música e alegria é quebrada (como convém ao clima negativo do romance) pela convocação de Harold para lutar na Segunda Guerra Mundial. Ele será morto em combate, o que traz para o enredo a questão da participação dos negros nas guerras norte-americanas: quando elas acontecem, os negros são convocados a cumprir seu dever patriótico (com grandes sacrifícios, visto que são geralmente colocados em missões de elevado risco por seus superiores brancos); quando elas terminam, os negros retornam para casa e para sua condição de excluídos dos supostos benefícios da cidadania as quais defenderam em combate.

Depressão (anos 30): a depressão não afeta as finanças dos Collyer, pois antes mesmo dela atingir a economia do país, eles já haviam perdido boa parte de sua fortuna. A clima de desesperança dos anos da Depressão entra na casa na forma de um "chá dançante" (p. 73) que os irmãos promovem nas tardes de terça-feira e que terminam quando a polícia resolve atuar depois de uma recusa de Langley ao pagamento de propina. Na ocasião desses chás, a casa adquire um caráter de espaço público que se repetirá novamente apenas nos anos 60, quando um grupo de hippies ocupa a casa por breve período:

$\mathrm{Na}$ verdade, no computo geral, acabei considerando nossos chás dançantes das terças-feiras como ocasiões de luto público. Nem mesmo o comunista que ficava ao pé dos nossos degraus de entrada 
para distribuir seus panfletos conseguia animar os dançarinos ${ }^{517}$. (p. 77)

O comunista na entrada da casa é uma referência ao crescimento da esquerda nesse momento de crise do capitalismo. Que ele fique fora da casa e seja até hostilizado por Langley é uma confirmação da recusa dos irmãos a se engajar nas formas tradicionais de atuação política. Certamente, o espírito de oposição dos dois os alinharia à esquerda, mas nesse romance a posição política em destaque é o não-posicionamento ou a recusa da política, o que, de certa forma, traz o espírito de indecisão figurado em The Book of Daniel para um paroxismo de apatia.

Significativamente, esses momentos de comunhão em que a casa dos Collyer deixa de ser um refúgio privado ocorrem em momentos em que há algum sentimento de mobilização em torno da maior visibilidade de questões de interesse coletivo: a aguda crise econômica nos anos 30 e a Guerra do Vietnam nos anos 60.

\section{Ataque japonês à Pearl Harbor (1941) e a decorrente perseguição do FBI aos japoneses e descendentes de japoneses que moravam nos Estados Unidos, muitos dos quais foram levados para campos de concentração: o casal Hoshiyama, americanos} filhos de japoneses, trabalha na casa dos Collyer. Após Pearl Harbor, os Hoshiyama começam a sofrer a hostilidade e até a violência dos vizinhos e pedem abrigo aos seus patrões. Logo, eles recebem a visita de agentes do FBI que os colocam sob custódia do estado. São levados para campos de concentração, para a indignação dos irmãos. Sobre a atuação do FBI, Langley reflete: "Essas pessoas ignoram a Constituição sempre que querem. Diga-me, Homer, como é que somos livres se isso só ocorre por condescendência deles? ${ }^{518 "}$ (p. 105) No quadro de desilusões que vai promovendo a educação dos Collyer sobre os mitos americanos, esse episódio é mais um "daqueles sermões sem palavras que a vida nos faz ouvir ${ }^{519 "}$ (p. 145).

\footnotetext{
${ }^{517}$ No original: In fact, what with one thing or another I had come to regard our Tuesday tea dances as occasions for public mourning. Even the Communist who stood at the foot of the front steps to pass out his flyers couldn't rouse up our tea dancers.

${ }^{518}$ No original: These people ignore the Constitution whenever they so choose. Tell me, Homer, how we are free if it's only at their sufferance?

${ }^{519}$ No original: ...one of life's own speechless sermons.
} 
Segunda Guerra Mundial: no romance, como veremos adiante, as guerras pontuam a evolução dos graus de isolamento dos Collyer. A Segunda Guerra levou da casa os Hoshiyama e a vovó Robileaux, tia de Harold, que volta para New Orleans depois da notícia da morte do sobrinho em combate na Europa. A partir daí, Homer e Langley estão sozinhos e não há mais empregados na casa para lembrar os tempos de riqueza da família.

A Segunda Guerra Mundial expõe um conflito de opiniões entre Homer e Langley. O narrador, nesse ponto ainda não totalmente desfeito de ilusões, contesta em silêncio a posição de seu irmão sobre a guerra:

Langley e eu discordávamos em relação à guerra. Ele não a via nos mesmos termos patrióticos, sua visão era olímpica, desdenhava da própria ideia de guerra exceto para apontar quem estava certo e quem estava errado. Seria isso um efeito prolongado do gás de mostarda? A guerra, a seu ver, era a única indicação óbvia da insuficiência humana. Mas havia pontos específicos nessa Segunda Guerra Mundial, em que o mal podia ser justificavelmente apontado, e eu achava essa atitude antagônica desencaminhada ${ }^{520}$. (p. 101)

Langley funciona na narrativa como uma espécie de superego crítico para o otimismo do narrador. No entanto, são os acontecimentos históricos que vão transformando Homer em um pessimista como seu irmão.

Há, no trecho acima, uma dialética entre o universal e o histórico que vai se repetir na narrativa. O senso comum declara a Segunda Guerra Mundial a última "guerra moral" do século. O próprio oximoro já diz bastante do confuso século que o formulou. Aqueles que apoiavam a guerra se sustentavam no fato de que, nesse conflito, "o mal podia ser justificavelmente apontado". É claro que é bem mais fácil tomar partido quando em um dos lados estão Hitler e Mussolini. No entanto, Langley condena a guerra baseado num imperativo categórico: todas elas trazem uma "indicação óbvia da insuficiência humana". O fato da oposição de Langley à Segunda Guerra ser baseado em uma posição filosófica universalista é mais uma mostra de que seu "contrarianism" não busca lastro nos

\footnotetext{
${ }^{520}$ No original: Langley and I disagreed about this war. He didn't see it in the same patriotic terms, his view was Olympian, he scorned the very idea of it apart from who was right and who was wrong. Was this a lingering effect of the mustard gas? War to his mind was only the most obvious indication of the fatal human insufficiency. But there were specifics to this Second World War, where evil could justifiably be assigned, and I thought his contrarian attitude was misguided.
} 
acontecimentos do dia, mas sim em "formas universais" Por isso, ressaltamos, sua posição representa uma negação da história, e sua recusa ao engajamento político nas questões de seu tempo é expressão dessa negação. Fosse ele um opositor historicamente consciente de seu tempo, poderia formular sua crítica baseandose, por exemplo, na ideia (defendida por Herbert Marcuse e outros Frankfurtianos) de que o fascismo, antes de ser uma excrecência do capitalismo, é a realização de seu sonho mais pervertido: uma sociedade dominada, pela ideologia e pela força, na qual não há espaço para contestação.

Holocausto: durante os primeiros anos da Segunda Guerra, a comunidade judaica americana se organizou para tornar públicos os crimes cometidos na Alemanha contra os judeus e exigir a entrada dos Estados Unidos no conflito na Europa. Em cidades como Nova York, judeus batiam de porta em porta para contar aos americanos o que acontecia nos guetos da Alemanha e dos países ocupados e para levantar fundos com o objetivo de financiar a fuga de judeus da Europa. A memória dessas visitas é vívida para o judeu E. L. Doctorow ${ }^{522}$ e aparece como fato marcante na infância de dois de seus personagens: Daniel (The Book of Daniel) e Edgar (narrador do romance autobiográfico World's Fair). O personagem Edgar relata uma dessas visitas:

Agora eram mais frequentes as visitas dos velhos homens de preto que usavam os xales de oração sobre os sobretudos e levavam cartas dos rabis e credenciais das yeshivas. Agora eram convidados a entrar. Minha mãe os recebia na sala e servia chá. Eles contavam histórias em voz baixa ou falavam só em iídiche, assim, minha escuta clandestina não conseguia obter nada de específico. Mas eu começava a pegar o sentido das coisas. Finalmente, um deles falou bastante em inglês para que as coisas se esclarecessem.

- As kinder são enxotadas das escolas, portanto não podem ir. E os negócios dos pais são tomados deles. Aos poucos. E na rua eles os ofendem, os pagãos de camisas pardas, e cospem neles. E eles têm de se apresentar à polizei. Milhares estão deixando o país, madame. Seus lares, seu meio de vida acabaram. Tudo acabou. Para a

\footnotetext{
${ }^{521}$ Adiante, será mostrado que Homer qualifica de platônico o projeto de Langley de criar um jornal em única edição para todos os tempos.

522،"Every day, it seemed, old men knocked on the front door to ask my mother for Money to help bring Jews out of Europe" (DOCTOROW, E. L. Reporting the Universe. Cambridge, London: Harvard University Press, 2003, p. 17).
} 
Palestina, em navios, mas para qualquer lugar! Para onde podem ir? O que podem fazer ${ }^{523}$ ?

A gravidade da situação não escapa nem ao olhar ingênuo de uma criança. Ingênua também é a crença de Langley de que a imprensa americana ignorava a verdade contada de porta em porta pelos "velhos homens de preto", como vemos na passagem:

Eu não tinha dúvidas de que o que ele dizia era verdade, mas era ao mesmo tempo tão chocante que quase pedia para não acreditarmos. Langley disse para mim depois: Como é que aqueles velhos que bateram a nossa porta sabiam mais do que as agências de notícias? ${ }^{524}$ (p. 108)

O espanto de Langley com a suposta ignorância das agências de notícia e a desobediência governamental à Constituição (como na passagem sobre o FBI) lembram a ingenuidade de Paul Issacson em The Book of Daniel. A força da ideologia é tão intensa nos universos ficcionais criados por Doctorow que seus personagens, mesmos os mais subversivos, só podem receber com espanto notícias do mau funcionamento da máquina capitalista. As zonas de resistência figuradas nesses romances sucumbem à violência de estado (Paul, Rochelle, Coalhouse Walker Jr são mortos, Emma Goldman é deportada, o Irmão mais velho foge para o México para lutar pela revolução lá, Susan se suicida...) ou se rendem ao canto da sereia da ideologia (Tateh vira um rico empresário do cinema). Da galeria de personagens radicais existentes no conjunto ficcional de Doctorow, somente Emma Goldman (Ragtime) e Artie Sternlicht (The Book of Daniel) esboçam projetos emancipadores. Ainda assim, a posição periférica que esses personagens ocupam nos

${ }^{523}$ DOCTOROW, E. L. A Grande Feira. São Paulo: Companhia das Letras, 1988, p. 95.No original: More frequently now there came to the front door the old men in black who wore their prayer shawls under their coats and carried letters from rabbis and credentials from yeshivas. Now they were invited in. My mother sat them in the parlor and gave them tea. They told their stories in hushed tones or spoke only in Jewish, and so my eavesdropping didn't yield anything that specific. But I was getting the gist of things. And finally one man spoke enough English to make it clear. "The kinder from the schools are pushed, so now they can't go. And the business of the fathers are taken from them. Little by little. And in the street they revile them, the brownshirt heathen, and spit on them. And to the polizei they must report. Thousands are leaving, Missus. Their homes, their livelihood is gone. All of it gone. To Palestine, on boats, but anywhere! Where can they go! What can they do! (DOCTOROW, E. L. World's Fair. New York: Random House, 2007, p. 100).

${ }^{524}$ No original: I had no doubt that what he was saying was true, but it was at the same time so shocking as almost to demand not to be believed. Langley said to me afterward: How is it those old men who knocked on our door knew more than the news organizations? 
romances não permite que cogitemos a presença de um grande potencial utópico nesses projetos.

Fim da Segunda Guerra, V-J DAY (Victory over Japan): ao final da Segunda Guerra, repete-se a euforia da "Parada do Armistício", que comemorou o fim da Primeira Guerra Mundial, a guerra que prometia por fim a todas as guerras. A ironia da repetição não escapa a Homer:

Quando a guerra terminou, com a vitória sobre o Japão, era um daqueles dias opressivamente fechados de agosto em Nova York. Não que alguém se importasse. Carros desfilavam ao longo da Fifth Avenue, motoristas tocando suas buzinas e gritando pelas janelas. Ficamos no alto de nossa escadaria como generais passando a tropa em revista, porque as pessoas corriam juntas umas das outras como se fossem fileiras, milhares de passos rumo ao centro da cidade em busca de festa. Eu tinha ouvido a mesma agitação, as mesmas risadas, os pés em correria como o sussurro das asas dos pássaros, do Dia do Armistício de $1918^{525}$. (p. 116)

Bomba Atômica: com essa invenção, pela primeira vez o homem concebe um instrumento capaz de pôr fim a toda a existência na terra. $\mathrm{O}$ pessimismo trazido por tal percepção é inevitável:

Ouvíamos alguns deles falar e então eu tinha de ouvir o comentário de Langley. Dizia-me coisas que eu sabia que eram verdade, mas que, ainda assim, eu não queria ouvir, porque tudo aquilo aumentava minha depressão. Finalmente, ele parou de me oferecer suas visões políticas, que se resumiam a uma esperança de haver em breve uma guerra mundial nuclear na qual a raça humana se extinguiria, para grande alívio de Deus... ${ }^{526}$ (p. 121)

\footnotetext{
${ }^{525}$ No original: When the war ended with the victory over Japan it was one of those oppressively close August days in New York. Not that anyone minded. Cars paraded along Fifth Avenue, drivers blowing their horns and shouting out the windows. We stood at the top of our stoop like generals taking review, because people were running by as closely as in ranks, thousands of footsteps scuttling downtown looking for the party. I had listened to the same excitement, the laughter, the running feet like the whir of birds' wings, on Armistice Day 1918.

526 No original: We'd listen to some commentator and then I'd have to listen to Langley commentating. He would tell me things I knew were true but which nevertheless I didn't want to hear, all of it just adding to my depression. Eventually, he would stop giving me his political insights, which boiled down anyway to a hope that there would soon be a nuclear world war in which the human race would extinguish itself, to the great relief of God.
} 
Guerra da Coreia (1950-53) e corrida armamentista: o padrão de repetição de catástrofes que Langley sintetiza em sua Teoria das Substituições é verificado por Homer com o início de mais uma guerra. Um acréscimo de estupidez humana é trazido pela competição nuclear entre Estados Unidos e URSS. Homer observa esses dois fatos:

Quando eu tocava piano para os filmes mudos, o filme terminava e o projetista enfiava a cabeça para fora da cabina. O próximo filme já vai começar, dizia. Um momento, por favor, enquanto trocamos os rolos.

E assim estávamos em guerra na Coreia, mas, como se precisássemos de algo de maior substância, nós e os russos estávamos correndo para construir bombas nucleares maiores do que as bombas jogadas no Japão. Quantidades intermináveis delas - para jogarmos uns sobre os outros. Eu imaginava que seriam suficientes apenas duas ou três superbombas para calcinar os continentes, ferver os mares e sugar todo o ar da atmosfera, mas aparentemente eu estava enganado ${ }^{527}$ (p. 120)

Surgimento da Televisão: para o narrador cego, a televisão é imaginada como uma espécie de "rádio pictórico" (p. 123). Avessos aos avanços tecnológicos, os irmãos aderem à televisão por curiosidade filosófica, mas logo a desligam para sempre. Em uma crítica ao potencial imbecilizante dessa invenção, Langley lembra um ritual dos índios amazônicos Jivaros para usar como metáfora dos efeitos da televisão no povo americano:

Li em algum lugar. Depois que você decapita o sujeito, você faz uma incisão do alto da cabeça até o fim da nuca e então arranca todo o recheio e tudo o mais do crânio - pescoço, escalpo e rosto. Costura como se fosse uma bolsa, sutura as pálpebras e os lábios, enche com pedras e ferve a porcaria toda até que fique do tamanho de uma bola de beisebol. (...) Imagine o povo americano vendo televisão. ${ }^{528 " ~(p . ~ 126) ~}$

\footnotetext{
${ }^{527}$ No original: When I played piano for the silent movies the picture would end and the projectionist would stick his head out of the booth. The next feature will begin shortly, he'd say. A moment, please, while we change reels.
}

And so there we were at war in Korea, but, as if we needed something of more substance, we and the Russians were racing to build bigger nuclear bombs than the bombs dropped on Japan. Endless numbers of them-to drop on each other. I should have thought just a couple of superbombs to char the continents and boil the seas and suck up all the air would be sufficient to the purpose, but apparently not.

${ }^{528}$ No original: Read it somewhere. After you decapitate the guy you make a slit from top of the head down the back of the neck and then peel the whole thing off the skull - neck, scalp, and face. Sew it into a pouch, stitch up eyelids and lips, fill it with stones, and boil the damn thing down till it's the size of a baseball. (...) Think of the American people watching television. 
Macarthismo: rápida menção (p. 124). Esse é o grande cenário de The Book of Daniel. O conteúdo fascista desse período da história norte-americana certamente qualifica-o para o panorama sombrio que Langley desenha. Sua presença tímida na narrativa se deve, creio, ao fato de que os irmãos não desenvolvem nenhum tipo de militância política que pudesse comprometê-los (lembremos do episódio da deportação de Anna em que Langley fala com desdém dos grupos de esquerda). Já no romance de 1971, a história da esquerda nos Estados Unidos é o grande tema, e o macarthismo, como política de perseguição sistemática de militantes de esquerda, não pode ficar fora dessa história.

Chegada do homem à Lua: clímax da Corrida Espacial, a chegada do homem à lua havia sido prometida pelo presidente Kennedy em 1961. Em 1969, quando a Apolo 11 aterrissa em solo lunar, o feito é celebrado como uma vitória americana sob os russos, uma demonstração da superioridade tecnológica dos Estados Unidos. Langley pratica seu “contrarianism" ao ler esse evento na contramão da geral euforia:

Vou lhe contar as boas notícias dessa aventura no espaço, Homer. A boa notícia é que a Terra acabou, senão por que estaríamos fazendo isso? A espécie tem uma grande percepção subliminar de que vamos explodir o planeta com nossas guerras nucleares e portanto precisamos nos preparar para sair daqui. A má notícia é que se conseguirmos de fato sair da Terra, vamos contaminar o resto do universo com nossa insuficiência moral ${ }^{529}$. (p. 156)

Guerra do Vietnam: último dos grandes conflitos do século XX presenciados por Homer e Langley. Entra na vida dos Collyer por meio de menções ao conflito e pelo encontro com hippies no Central Park em evento de protesto contra a guerra. Como ocorre em The Book of Daniel, essa guerra tem uma presença oblíqua no enredo, não virando objeto de escrutínio nem dos narradores nem de personagens.

Movimento Hippie: um grupo de hippies que participa de uma manifestação pacifista no Central Park entra sem cerimônias na casa dos Collyer, que eles consideram um "templo

\footnotetext{
${ }^{529}$ No original: I'll tell you the good news about this space venture, Homer. The good news is that the earth is finished, or why would we be doing this? There is a great subliminal species perception that we are going to blow up the planet with our nuclear wars and must prepare to leave. The bad news is that if we do in fact get off the earth we will contaminate the rest of the universe with our moral insufficiency.
} 
da dissidência" (p. 168). Os hippies ocupam uma parte significativa do romance (da página 162 a 183). Nessa torrente de eventos que se sucedem rapidamente no tempo da narrativa, o espaço ocupado pelos hippies é significativo e funciona como uma espécie de interlúdio lírico no desfile de catástrofe que é o enredo desse romance. Drogas, Rock'n'roll, filosofia, sexo, artes visuais movimentam os dias de Homer e Langley durante a estada dos hippies. A identificação dos Collyer com a "filosofia de vida" dos hippies atesta, definitivamente, o caráter não-engajado da identidade política dos irmãos. Homer demonstra essa identificação ao valorizar a atitude de recusa dos hippies como criticamente mais profícua do que o engajamento dos militantes do movimento pelos direitos civis (Martin Luther King) e dos grupos contrários à Guerra do Vietnam (a Nova Esquerda Americana sendo o principal deles):

Vivendo como viviam, esses garotos eram críticos mais radicais da sociedade do que o pessoal dos movimentos contra a guerra ou pelos direitos civis, que ganhavam tanta atenção nos jornais. Não tinham nenhuma intenção de melhorar as coisas. Eles simplesmente rejeitavam toda a cultura. Se compareceram àquele comício contra a guerra no parque, foi porque havia música lá e era agradável sentar-se na grama, tomar vinho e fumar uns baseados. Eram itinerantes que haviam escolhido a pobreza e eram jovens e insensatos demais para pensar no que a sociedade acabaria fazendo contra eles a título de vingança. (p. 168)

No panorama político dos anos 60 desenhado em The Book of Daniel, os hippies não tem espaço. A única menção clara a eles aparece na caracterização de Phyllis como uma "flower girl”. Trata-se de uma menção negativa, já que, como vimos, a esposa de Daniel é comparada por ele a sua irmã, e nessa comparação Phyllis é caracterizada como o oposto da inteligência, força moral e engajamento de Susan. Há uma leve menção à moda hippie na mudança de visual de Daniel no final do romance, mas essa mudança reflete mais o estado de confusão do narrador e seu completo mergulho nos problemas que o rondam (ele caracteriza esse novo estilo como seu "fuck everyone persona") do que uma adesão à cultura hippie.

Se pensarmos o romance Homer \& Langley como uma espécie de súmula dos temas e momentos históricos presentes na ficção de Doctorow sobre o século XX, os hippies se juntam a Artie, Susan e Daniel para ampliar o quadro histórico dos anos 60 ricamente pintado em The Book of Daniel. 
Marcha ao Pentágono (1967): evento somente mencionado. Como vimos acima, os Collyer, não sendo militantes ativos de nenhum grupo de esquerda e adotando uma postura de renúncia e reclusão, não se sentem atraídos por esse importante episódio do final dos anos 60, que, embora tenha acontecido em Washington, mobilizou pessoas de várias partes dos Estados Unidos que se organizaram para ir à capital do país protestar. Aqui, novamente, o contraste com The Book of Daniel se impõe, uma vez que no romance de 1971 a Marcha representa um momento de busca e de revelação para Daniel, como vimos no primeiro capítulo dessa tese.

Watergate e Renúncia de Richard Nixon (1974): Langley,ao falar da conduta de Nixon no episódio que determinou sua renúncia, parece prever a recorrência de casos semelhantes em um futuro que ele não vai poder presenciar:

Conduta ilegal do presidente da República naqueles anos também foi outra rubrica para seu arquivo condicional. Até que outro presidente subvertesse a Constituição que jurara respeitar, não podia ser considerado como seminal. Mas estou esperando, disse $\operatorname{ele}^{530}$. (p. 191)

Sabendo do posicionamento de Doctorow contra o poder de vigilância quase irrestrito concedido ao governo Bush logo após os eventos de 11 de setembro de $2001^{531}$ e depois contra a injustificável invasão americana do Iraque ${ }^{532}$, percebemos na fala de Langley um claro recado para o presente.

\footnotetext{
${ }^{530}$ No original: Presidential malfeasance in these years was another entry for his conditional file. Until another president subverted the Constitution he was sworn to uphold, it couldn't be considered as seminal. But I'm waiting, he said.

${ }^{531}$ Expresso em entrevistas, artigos e falas públicas do autor nos últimos anos.

${ }^{532}$ Em discurso para estudantes universitários, Doctorow compara Bush a um romancista e fala de algumas das ficções criadas pelo presidente: "One story he told was that the country of Iraq had nuclear and biological and chemical weapons of mass destruction and was intending shortly to use them on us. That was an exciting story all right, it was designed to send shivers up our spines. But it was not true. Mr. Bush told stories about Saddam Hussein, that he was in league with the terrorists of al Qaeda. And that turned out to be not true. But anyway we went off to war on the basis of these stories". (NOONAN, Peggy. Doctorow's Malpractice - Hofstra students use boos responsibly. The Wall Street Journal. May 25, 2004. http://online.wsj.com/news/articles/SB122459862152754103).
} 
A comparação com os dois romances da década de 70 (The Book of Daniel, 1971; Ragtime, 1975) estudados nos capítulos anteriores evidencia uma certa timidez formal ${ }^{533}$ em Homer \& Langley. Quando o conteúdo sócio-histórico está sedimentado na forma (fato que creio acontecer em Daniel e em Ragtime), o resultado artístico pode ser uma fatura truncada, problemática, com lacunas e indefinição que traduzem as próprias contradições do material social do qual são feitas. Não quero, com isso, sugerir que avanços cognitivos em romance hoje signifiquem necessariamente formas fragmentárias, descontínuas, difíceis. Quero tratar do que ocorre nesse romance de Doctorow. Nele, o material social problemático (os traumas históricos de um século de "extremos ${ }^{534 \text { " e os }}$ problemas de representação atuais) é tratado no nível do diálogo, com os personagens elaborando teorias e comentários críticos e filosóficos sobre o mundo em que vivem. $\mathrm{O}$ único índice claro de elaboração formal desse romance aparece na figura do narrador, da qual falaremos adiante.

A timidez formal de Homer \& Langley aparece, por exemplo, nesse trecho sobre Nixon. Se o romance histórico deve figurar a história como "precondição concreta do

\footnotetext{
${ }^{533}$ Observadas as diferenças entre artes plásticas e literatura e entre os contextos históricos estudados, a "timidez formal" que descrevo aqui como uma hesitação ou incapacidade de propor grandes rupturas, de dar grandes saltos perceptivos, guarda semelhanças com a timidez formal de parte da produção artística brasileira, como descrita por Rodrigo Naves:
}

"A produção moderna internacional, escusado dizer, se caracterizou por uma aparência forte, devida sobretudo a uma significativa redução da natureza representativa de seus elementos. Linha, cor, superfície adquiriram um novo estatuto, na medida em que não apenas evocavam seres e coisas ausentes como também se mostravam com uma intensidade até então desconhecida. $\mathrm{O}$ abandono do ilusionismo perspectivista reforçou os limites físicos das obras e aumentou consideravelmente a presença dos elementos que as constituíam.

Algo significativamente diverso ocorre com a arte brasileira. Grande parte dos trabalhos realizados entre nós incorpora sem dúvida as mudanças modernas, mas com um viés todo particular. As obras se vêem envolvidas numa morosidade perceptiva que reduz a força de seu aparecimento. Cores, formas, linhas têm uma certa autonomia e já não precisam se ocultar por entre os seres que figuram. No entanto essa independência conduz quase sempre a um jogo peculiar, em que faturas, formas e dimensões parecem se ocupar consigo mesmas, adiando indeterminadamente sua definição visual. Sua leveza, a ausência decidida de um lastro que as separe de si mesmas, é também um descompromisso com a exterioridade.

Em seu permanente cismar, essas obras poderiam sugerir um processo de gênese das formas, um tipo de preocupação presente em várias tendências modernas. No entanto, o movimento não se cumpre." (NAVES, Rodrigo. A Forma Difícil. São Paulo: Ática, 1996, p. 12).

${ }^{534}$ HOBSBAWM, Eric. The Age of Extremes - A History of the World, 1914-1991. New York: Vintage Books, 1996. 
presente 535 ", Doctorow esboça tal movimento de figuração ao procurar no caso Watergate um prenúncio dos atos do governo Bush. No entanto, a conexão entre passado e presente é feita de forma ingênua, com um personagem falando aqui o que o autor poderia dizer em um artigo de jornal, por exemplo.

Para esclarecer esse ponto, falarei da minha experiência de leitura. Passados quatro anos de estudos, creio ter lido boa parte da fortuna crítica sobre a obra de Doctorow e praticamente tudo o que o autor publicou. Também acompanhei entrevistas, palestras e leituras públicas disponíveis em vídeo e áudio na internet. Esses anos de estudo me trouxeram grande familiaridade com as ideias e o estilo do autor. Ao ler Homer \& Langley, percebo a presença do autor de uma forma que não acontece nos romances anteriormente estudados. Essa percepção é clara no trecho sobre Nixon e Bush. Ao ler esse trecho pela primeira vez, percebi claramente a voz do autor explícito se sobrepondo à voz do narrador e à fala reportada do personagem Langley. Como numa partida de futebol em que a presença do árbitro, quando notada, sinaliza problemas no jogo, a presença do romancista no romance (exceto em casos em que essa presença seja parte orgânica da forma) indica uma fatura imperfeita, na qual a mão do criador deixa marcas visíveis no produto final.

\section{Suicídio em massa dos seguidores do Pastor Jim Jones, líder e fundador da Peoples}

Temple, na Guiana (1978): esse acontecimento é tratado como a emergência do irracional no comportamento humano. Ele desafia a catalogação de comportamentos humanos que Langley pretende criar com seu jornal em única edição (do qual falaremos adiante). Junto com o próximo evento dessa lista, esse suicídio coletivo precipita o isolamento total dos irmãos.

1980 - Assassinato, em EI Salvador, de quatro freiras norte-americanas por militares que haviam sido treinados pela CIA: Mary Elizabeth Riordan é uma estudante de música, filha de imigrantes, que é contratada para trabalhar com Homer no cinema mudo. Em troca do serviço de "olhos do cinema 536 " (p. 48) prestados ao Collyer cego, Mary

\footnotetext{
${ }^{535}$ LUKÁCS, Gyorgy. O romance histórico. São Paulo: Boitempo, 2011, p. 36.

${ }^{536}$ No original: ...movie eyes.
} 
recebia dinheiro e aulas de piano, uma vez que a situação financeira dos irmãos começava a se deteriorar nessa época. Logo, a jovem de dezesseis anos passa a morar na casa dos Collyer e vai conquistando os dois irmãos, que a tratam como filha mas nutrem, secretamente, uma paixão pela moça. Um dia, ela se despede e parte. Muitos anos depois, uma carta da Irmã Mary Elizabeth Riordan chega aos Collyer e os surpreende com notícias do destino da jovem estudante de piano, agora missionária. Um dia, Langley lê no jornal sobre o estrupo e assassinato de quatro freiras americanas em El Salvador. Eles correm para conferir o selo da carta que haviam recebido de Mary e constatam, com devastador pesar, que ela havia sido enviada desse país.

Esse evento brutal sela para sempre a casa dos Collyer, como nos informa Homer: "Nossas venezianas nunca mais seriam abertas" (p. 194). Ele marca também o começo do gradual apagamento perceptivo do narrador:

Foi por volta dessa época que notei que meu precioso Aeolian estava meio-tom desafinado nas oitavas médias" (p. 197). (...) "Meses se passariam antes que, decibel por decibel, o mundo ficasse abafado e eu perdesse meu orgulhoso ouvido inteiramente e ficasse pior do que Beethoven, que pelo menos podia enxergar ${ }^{537}$ (p. 199).

O acerto da decisão pelo isolamento completo é confirmado, para o narrador, pela deterioração da cidade de Nova York na época:

Certamente, não nos ajudava em nossas relações com nossos vizinhos e nos contratempos com as burocracias da cidade o fato de que toda Nova York da época experimentava uma deterioração na ordem civil: serviços municipais em colapso - lixo não recolhido, vagões de metrô grafitados -, crimes de rua em ascensão, abundância de viciados em drogas. Entendi também que nossos times esportivos profissionais estavam se saindo muito mal nos campeonatos. Sob estas circunstâncias, nossas venezianas fechadas e a tranca em nossa porta pareciam fazer sentido. Minha vida agora estava inteiramente na casa ${ }^{538}$. (p. 197)

\footnotetext{
${ }^{537}$ No original: It was around this time that I noticed my precious Aeolian was off by a half tone in the middle octaves. (...) Months were to go by before, decibel by decibel, the world would grow muffled and I would lose my prideful hearing entirely and so be worse off than Beethoven, who could at least see.

${ }^{538}$ No original: It certainly didn't help us in our relations with the neighbors and contretemps with the city bureaucracies that all of New York at this time was experiencing a deterioration in the civil order: municipal services breaking down - uncollected garbage, graffitied subway cars - street crimes rising, drug addicts abounding. I understood too that our professional sports
} 
Nos últimos meses de vida dos irmãos, Jacqueline Roux, uma escritora francesa

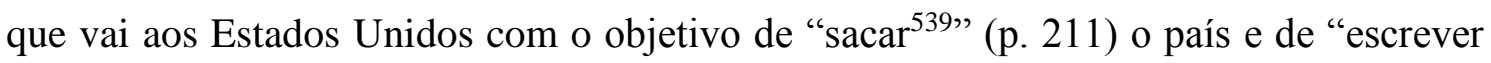
sobre o que não pode ser visto" (p. 211), procura os Collyer para entender as razões do isolamento dos, por essa altura, famosos nova-iorquinos. Em diálogo com Homer, ela sugere uma leitura simbólica do fechamento das venezianas:

Quando encontrei seu endereço, olhei para sua casa com suas venezianas pretas. Na Europa temos venezianas para as janelas, aqui não tanto quanto eu imaginaria. Na França, na Itália, na Alemanha, as venezianas existem por causa de nossa história. A história torna aconselhável ter venezianas pesadas sobre as janelas e fechá-las à noite. Neste país as casas não são escondidas atrás de paredes, dentro de pátios. Vocês não têm história suficiente para isso. Seus lares confrontam a rua sem medo, para todo mundo ver. Então por que você tem venezianas pretas nas janelas, Homer Collyer? O que significa para a família Collyer ter as venezianas fechadas num dia quente de primavera? ${ }^{540}$ (p. 211)

Homer não sabe responder a essa pergunta. O que está implícito nela é um questionamento do mito do excepcionalismo americano, uma crença amplamente aceita nos Estados Unidos segundo a qual a ausência de um passado aristocrático no novo mundo teria deixado esse território livre de um legado de hierarquias rígidas e divisões de classe. Daí deriva outro mito americano: o da inexistência de classes nesse país. Tal leitura do isolamento dos Collyer, sendo proposta no final do livro, exige uma reavaliação do significado e das possibilidades desse gesto de separação.

As interrogações trazidas para a narrativa pela chegada da escritora francesa significam, sem dúvidas, um avanço cognitivo nesse romance que parece girar

teams were doing badly in the standings. Under these circumstances, our closed shutters and the two-by-four bolt on our front door seemed to make sense. My life now was entirely in the house.

${ }^{539}$ No original: to get.

${ }^{540}$ No original: When I found your address I looked at your house with its black shutters. In Europe we have shutters for the windows, not here so much I should have thought. In France, in Italy, in Germany, the shutters are because of our history. History makes it advisable to have heavy shutters on the windows, and to close them at night. In this country the homes are not hidden behind walls, within courtyards. You have not enough history for that. Your homes confront the street unafraid, for everyone to see. So why do you have black shutters on your windows, Homer Collyer? What does it mean for the Collyer family to have the shutters closed on a warm spring day? 
indefinidamente em torno de uma visão pessimista da história do século XX. A relação sugerida por Jacqueline entre o fechamento simbólico das venezianas e a história americana poderia, não fosse sua chegada tardia, colocar a questão do separatismo dos Collyer em outro nível: não se trataria de perceber os elementos idiossincráticos da história desses dois "excêntricos" nova-iorquinos e de buscar explicações pessoais ou psicológicas para sua narrativa; tratar-se-ia, sim, de investigar as forças históricas que empurraram os Collyer para dentro de sua casa num isolamento irreversível e de entender os limites construtivos dessa alegoria da desconexão. No entanto, a morte do narrador poucas páginas após a entrada de Jacqueline no enredo fecha as cortinas da narrativa e ficamos com as perguntas em aberto. Do ponto de vista alegórico, essa falta de resolução após o questionamento ter sido colocado é ela mesma sintomática da situação atual de indefinição.

Fatos da história dos Estados Unidos no século XX se sucedem a cada página virada do romance. Mesmo distanciados do mundo por seu isolamento voluntário, Homer e Langley são afetados pelos ventos da história, que invadem sua casa à revelia dos seus esforços de separação. Homer comenta a chegada de objetos da Segunda Guerra Mundial comprados de veteranos por seu irmão: "Era como se os tempos soprassem através de nossa casa como um vento e essas fossem as coisas depositadas aqui pelos ventos da guerra $^{541 "}$ (p. 119). Doctorow, filósofo de formação, certamente conhece as Teses sobre o conceito de História de Walter Benjamin, o que nos autoriza a supor que a passagem acima faça referência à célebre tese de número $9^{542}$, sobre o Anjo da História que,

\footnotetext{
${ }^{541}$ No original: It was as if the times blew through our house like a wind, and these were the things deposited here by the winds of war.

542 "Há um quadro de Klee que se chama Angelus Novus. Representa um anjo que parece querer afastar-se de algo que ele encara fixamente. Seus olhos estão escancarados, sua boca dilatada, suas asas abertas. $\mathrm{O}$ anjo da história deve ter esse aspecto. Seu rosto está dirigido para o passado. Onde nós vemos uma cadeia de acontecimentos, ele vê uma catástrofe única, que acumula incansavelmente ruína sobre ruína e as dispersa a nossos pés. Ele gostaria de deter-se para acordar os mortos e juntar os fragmentos. Mas uma tempestade sopra do paraíso e prende-se em suas asas com tanta força que ele não pode mais fechá-las. Essa tempestade o impele irresistivelmente para o futuro, ao qual ele vira as costas, enquanto o amontoado de ruínas cresce até o céu. Essa
} 
impelido por uma tempestade, não pode se deter sob a cadeia de ruínas que se desenrola diante de seus olhos ${ }^{543}$.

Assim, o refúgio dos Collyer vai, ao longo da narrativa, sendo invadido por acontecimentos históricos. Essa inserção involuntária da casa no fluxo da turbulenta história do século XX é observada pelo narrador: [era] "como se nossa casa não fosse nossa casa, mas uma estrada pela qual Langley e eu viajávamos como peregrinos ${ }^{544 \text { " }}$ (p. $130)$.

O lar, refúgio burguês por excelência, há muito não está imune às ameaças do mundo exterior. Já no drama burguês do século XIX, o núcleo doméstico, cenários das intrigas e jogos de poder da burguesia, não constitui espaço impermeável às pressões externas, como aponta Raymond Williams:

Already in the drama of the 1880s and 1890s (Ibsen, Chekhov) this structure had appeared: the centre of dramatic interest was now for the first time the family home, but men and women stared from its windows, or waited anxiously for messages, to learn about forces, 'out-there', which would determine the conditions of their lives ${ }^{545}$.

No "planeta favela", no qual "ilhas de riqueza" são rodeadas por um contingente cada vez maior de morarias precárias ${ }^{546}$, narrativas que tratem da precária segurança do isolamento em meio às crescentes tensões sociais ganham uma força de lucidez necessária e merecedora de atenção. Em Homer \& Langley, a inevitável verdade sobre a inutilidade

tempestade é o que chamamos de progresso." (BENJAMIN, Walter. Magia e Técnica, Arte e Política - Ensaios sobre literatura e história da cultura. São Paulo: Brasiliense, 1994, p. 226).

${ }^{543}$ Perry Anderson localiza nessa alegoria de Benjamin um impulso semelhante ao que move o romance histórico contemporâneo: "O anjo da história está se distanciando de algo em que fixa a vista. 'Onde nós vemos uma cadeia de acontecimentos, ele vê uma catástrofe única, que acumula incansavelmente ruína sobre ruína e as dispersa a nossos pés. Ele gostaria de deter-se para acordar os mortos e juntar os fragmentos'. Parte do impulso do romance histórico contemporâneo pode também estar aqui" (ANDERSON, Perry. Trajetos de uma forma literária. Revista Novos Estudos - CEBRAP, número 77, março de 2007, pp. 205-220).

${ }^{544}$ No original: ... as if our house were not our house but a road on which Langley and I were traveling like pilgrims.

${ }^{545}$ WILLIAMS, Raymond. Television: Technology and cultural form. London New York: Routledge, 1974, p. 21.

${ }^{546}$ Cf. DAVIS, Mike. Planeta Favela. São Paulo: Boitempo, 2006. 
dos esforços de isolamento em meio à crise crescente só pode ser calada com a insensibilidade total do narrador, a definitiva perda dos sentidos que o ligam ao mundo, perda que o deixa apenas com uma "consciência crescente que lentamente desalojava o mundo fora de [sua] mente". Vejamos como o narrador relata esse processo:

Mas uma noite algo que Langley me dissera voltou-me à mente quando tentava dormir. Ele disse que tudo o que era vivo estava em guerra. Fiquei a imaginar se a diminuição de meus sentidos, mesmo quando eu estava aterrorizado por uma consciência crescente que lentamente desalojava o mundo fora de minha mente, enfim, se era possível que eu estivesse me tornando progressivamente alheio à verdade de nossa situação, à sua magnitude, protegido em minha própria insensibilidade do pior de suas imagens e de seus sons. Ao refletir, o apedrejamento de nossa casa por crianças, em vez de ser um episódio incidental a nossas preocupações maiores - nosso isolamento gradual, a perda, por nossa própria causa ou por causa de outros, dos serviços comuns da civilização urbana, sem água corrente, quero dizer, sem gás, sem eletricidade o fato de nos descobrirmos num círculo de animosidade que partia em ondas de nossos vizinhos para nossos credores, para a imprensa, para a municipalidade e, finalmente, para o futuro, pois isso é o que aquelas crianças eram, se, em vez de ser um evento de importância menor, não seria, na verdade, o golpe mais devastador de todos ${ }^{547}$. (pp. 227-228)

A estratégia de isolamento dos irmãos, em vez de os libertar, os aprisionou numa armadilha mortal:

A estratégia defensiva de Langley tornou perigoso, se não impossível, para mim, tentar sair tateando pela casa. Para todos os propósitos práticos, sou um prisioneiro. Estou situado agora dentro das portas da sala de estar com apenas uma trilha até o banheiro de sob as escadas. Langley também sofre restrições. Instalou-se na cozinha com acesso para dentro e para fora da casa pela porta dos fundos que dá para o jardim. O hall de entrada está completamente

\footnotetext{
${ }^{547}$ No original: But one night something Langley had said came back to me as I tried to sleep. He said everything alive was at war. I wondered if the diminution of my senses, even as I was terrified of an enlarging consciousness slowly displacing the world outside my mind-if it was possible that I was becoming progressively unaware of the truth of our situation, the magnitude of it, protected in my insensitivity from the worst of its sights and sounds. As I reflected, the stoning of our house by children, rather than being an episode incidental to our major concerns-our increasing isolation, losing by our own doing or the doing of others the ordinary services of an urban civilization, no running water, I mean, no gas, no electricity-and finding ourselves in a circle of animosity rippling outward from our neighbors to creditors, to the press, to the municipality, and, finally, to the future - for that was what these children were-rather than being of minor significance, well, that was the most devastating blow of all.
} 
bloqueado com caixas de livros empilhadas até o teto. Uma passagem estreita entre fardos de jornais e ferramentas de jardim penduradas - pás, ancinhos, uma furadeira, um carrinho de mão, tudo suspenso no ar por arames e cordas presos e espigões que ele cravou com martelo - leva de seu posto avançado na cozinha até meu enclave ${ }^{548}$ (pp. 233-234)

\section{A organização do pessimismo: Teoria das substituições, colecionismo e guerras.}

Concepções da História como repetição são formuladas por personagens de outros romances de Doctorow. Em Ragtime, o Menino, narrador do romance, tinha o hábito de guardar "como uma preciosidade tudo o que era jogado fora ${ }^{549 "}$ (p. 104). Para ele, "era evidente que o mundo se compunha e recompunha sem parar, num infindável processo de insatisfação ${ }^{550 ”}$ (p. 107). Ainda em Ragtime, John Pierpont Morgan revela, em inusitado diálogo com Henry Ford, sua crença na existência de padrões universais de repetição e ordem. Em O Livro de Daniel, Artie tem em seu apartamento uma parede repleta de imagens. Quando uma jornalista pergunta pelo título dessa obra, que ela descreve como uma colagem, ele responde: "TUDO O QUE VEIO ANTES DÁ NO $\operatorname{MESMO}^{551 "}$ (p. 149).

\footnotetext{
${ }^{548}$ No original: Langley's defensive strategy has made it unwise if not impossible for me to try to get around the house. For all practical purposes I am imprisoned. I am situated now just inside the doors of the drawing room with a single path to the bath under the stairs. Langley is also constrained. He has established himself in the kitchen with access in and out of the house through the back door to the garden. The front hall is completely blocked with boxes of books stacked to the ceiling. A narrow passageway between bales of newspaper and overhanging garden toolsshovels, rakes, a power drill, a wheelbarrow, all strung overhead by wire and rope from spikes he's hammered into the walls-leads from his kitchen outpost to my enclave.

${ }^{549}$ No original: The boy treasured anything discarded. (p. 115).

${ }^{550}$ No original: It was evident to him that the world composed and recomposed itself constantly in an endless process of dissatisfaction. (p. 118).

${ }^{551}$ No original: EVERYTHING THAT CAME BEFORE IS ALL THE SAME!
} 
Em nenhuma outra obra de Doctorow, no entanto, uma teoria da História como repetição é desenvolvida de forma tão sistemática quanto em Homer \& Langley. Tal teoria - chamada de "Teoria das Substituições" por Langley, seu criador - vai se desenvolvendo pari passu com o desenrolar violento e confuso da História presenciada e vivida pelos personagens no romance. O narrador nos informa dos passos na evolução da teoria de Langley, que chega a uma

...espécie metafísica de ideia da repetição ou recorrência dos acontecimentos da vida, as mesmas coisas acontecendo repetidamente, dado em especial os limites restritos da inteligência humana, sendo o Homo sapiens uma espécie que, em suas próprias palavras, não a tinha suficientemente. Portanto, o que se sabia do passado podia ser aplicado ao presente ${ }^{552}$. (p. 58).

Nas primeiras páginas do romance, encontramos Langley retornando da Primeira Guerra Mundial com a saúde debilitada por um ataque de gás mostarda. Ao chegar em casa, descobre que seus pais haviam morrido em um surto de gripe que atingiu a cidade. Enquanto ele sai para visitar os pais no cemitério, seu irmão fixa na parede o fuzil trazido da guerra, como um ato inaugural da coleção que os dois vão começar a constituir:

No dia em que Langley foi sozinho ao cemitério Woodlawn para visitar os túmulos de nossos pais, coloquei o fuzil Springfield sobre a lareira da sala de visitas e lá ele ficou, quase a primeira peça na coleção de artefatos de nossa vida americana ${ }^{553}$ (p. 31).

Há um impulso de compreensão no trabalho do colecionador que move os projetos de Langley, embora ele, com irônia, se descreva como apenas um "solene investigador

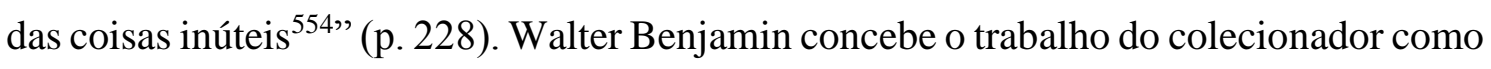
uma luta contra a dispersão:

\footnotetext{
${ }^{552}$ No original: ... a metaphysical sort of idea of the repetition or recurrence of life events, the same things happening over and over, especially given the proscribed limits of human intelligence, Homo sapiens being a specie that, in his words, just didn't have enough. So that what you knew from the past could be applied to the present.
}

${ }^{553}$ No original: On the day Langley went by himself up to the Woodlawn Cemetery to visit our parents' graves, I placed his Springfield rifle on the fireplace mantel in the drawing room and there it has stayed, almost the first piece in the collection of artifacts from our American life.

${ }^{554}$ Os versos citados por Langley são do poema "Passagem das horas", de Álvaro de Campos. O verso citado é "Eu, o investigador solene das coisas fúteis". A diferença entre o verso citado por Langley e o original de Fernando Pessoa se deve provavelmente ao fato de que o tradutor tenha 
Perhaps the most deeply hidden motive of the person who collects can be described this way: he takes up the struggle against dispersion. Right from the start, the great collector is struck by the confusion, by the scatter, in which the things of the world are found. (...) The collector (...) brings together what belongs together; by keeping in mind their affinities and their succession in time, he can eventually furnish information about his objects ${ }^{555}$. (p. 211)

Se há um tema recorrente na coleção dos Collyer, esse é a guerra. No esforço de "juntar o que pertence em conjunto", artefatos bélicos são trazidos para dentro da casa. Logo, um rifle M1 da Segunda Guerra será pendurado acima do fuzil Springfield como mais um item da "coleção de artefatos da vida americana" e como mais um argumento para a Teoria das Substituições de Langley. Tal teoria é assim descrita por seu criador:

Tudo na vida é substituído. Nós somos os substitutos de nossos pais, assim como eles foram os substitutos da geração prévia. Todos esses rebanhos de bisões que estavam chacinando no Velho Oeste, seria de se esperar que fosse ser o fim deles, mas não serão todos abatidos e os rebanhos serão refeitos com substitutos indistinguíveis daqueles que foram mortos ${ }^{556}$ (p. 19).

Homer, o narrador cego, não adere imediatamente à Teoria das Substituições, que ele entende ser fruto da "amargura" ou do "desespero em relação à vida" (p. 21) de Langley. Tal Teoria é, para Homer, a maneira que seu irmão encontrou para "sintetizar sua sombria visão da vida" (p. 62). Inicialmente otimista e feliz, Homer vai gradativamente se aproximando do "desespero filosófico" (p. 161) de seu irmão. Os sucessivos conflitos e eventos trágicos do século vão minando sua confiança e seu otimismo. Quando a Guerra do Vietnam começa, Homer declara seu crescente pessimismo:

utilizado o verso em inglês, como ele aparece no romance, como referência para a tradução: the solemn investigator of useless things.

555 BENJAMIN, Walter. The Arcades Project. Cambridge (USA), London: Harvard University Press, 1999.

${ }^{556}$ No original: Everything in life gets replaced. We are our parents' replacements just as they were replacements of the previous generation. All these herds of bison they are slaughtering out west, you would think that was the end of them, but they won't all be slaughtered and the herds will fill back in with replacements that will be indistinguishable from the ones slaughtered. 
Claro que outra Guerra maldita havia surgido e era suficiente para erradicar quaisquer inibições residuais que eu pudesse ter. Não teria este país nada de excepcional, no fim das contas? Àquela altura da minha vida, eu estava, em espírito, mais próximo do desespero filosófico de Langley ${ }^{557}$ (p. 161).

Como ilustração de sua teoria, Langley planeja criar um jornal em edição única que contemple toda a história do homem. Com essa "Edição Única Collyer para Todos os Tempos" (p. 115), Langley pretende "fixar a vida americana finalmente em uma edição, a que ele se referia como jornal Collyer sem data e eternamente atual, o único jornal de que alguém poderia necessitar ${ }^{558 "}$ (p. 60).

O conteúdo de conformismo implícito em tal teoria é fruto, como vimos, dos trágicos eventos que o romance elenca em sequência cronológica e que tem nas guerras uma mais-valia de sofrimento.

A presença das guerras nos outros romances de Doctorow é percebida indiretamente, como na peregrinação de judeus pelos lares americanos em busca de auxílio para seus irmãos na Europa (como visto em The Book of Daniel, World's Fair e em Homer \& Langley). Em The Book of Daniel, a guerra é uma sombra que afeta a vida dos americanos (a Segunda Guerra Mundial, a Guerra da Coreia e a Guerra do Vietnam tem papel importante na configuração histórica na qual os personagens do romance se movem e da qual sofrem as consequências), mas que é pouco mencionada diretamente. Em Ragtime, a narrativa termina com o começo da Primeira Guerra Mundial. A sombra da guerra paira por todo o enredo, na forma de uma pesada atmosfera de catástrofe iminente percebida por alguns personagens, como a Mãe e o Menino. Há o encontro de Houdini com o Arquiduque Franz Ferdinand e o premonitório alerta do Menino ao mágico: "Warn the Duke". O personagem Pai é o único que tem uma participação em eventos diretamente ligados à Guerra: ele morre no ataque alemão ao Lusitânia enquanto acompanhava um carregamento de bombas que vendera a várias nações europeias. Já The March (2005) é um romance sobre a guerra, mas a guerra como uma presença distante: a

\footnotetext{
${ }^{557}$ No original: Of course that another damnable war had sprung up was enough to strip away any residual inhibitions I may have had. Was this country unexceptional after all? I was at this point in my life as close in spirit to Langley's philosophical despair as I had ever been.

${ }^{558}$ No original: He wanted to fix American life finally in one edition, what he called Collyer's eternally current dateless newspaper, the only newspaper anyone would ever need.
} 
guerra retratada ali é a Guerra Civil Americana. É um romance que trata, de forma eloquente, da tragédia que toda guerra é para todos aqueles nela envolvidos. É um belo livro, mas um com mensagem antibelicista quase explícita, tendo sido escrito sob o impacto das guerras americanas pós 11 de setembro. Em Homer \& Langley temos, como já mencionei, uma súmula de vários temas históricos presentes nos romances de Doctorow. As guerras, que compõem os cenários dos outros romances, aparecem aqui num mesmo quadro histórico. O esforço de ligá-las em progressão histórica - implícito na "coleção de artefatos da vida americana" e no projeto do jornal em única edição para todos os tempos - pode ser visto como uma tentativa de diálogo entre os romances que encontra na guerra um leitmotiv. Fredric Jameson observou que, vistos em conjunto, os romances de Doctorow parecem querer delinear um panorama do século $\mathrm{XX}^{559}$. Em Homer \& Langley, esse projeto, implícito na obra de Doctorow, se mostra de maneira clara.

O batismo de fogo de Langley o prepara para um século de catástrofes. Para Homer, seu irmão é dotado da "força de não ter ilusões", o que o torna um observador crítico e potencialmente imune às falsas promessas do progresso:

Não era do feitio de meu irmão me desertar. Havia algo na visão de mundo de Langley, firmemente encastelado em seu nascimento, embora talvez polido com brilho na Universidade de Columbia, que lhe conferia imunidade divina a destinos tão rasteiros como a morte numa guerra: eram os inocentes que morriam, não aqueles nascidos com a força de não terem ilusões ${ }^{560}$. (p. 25)

A "organização do pessimismo" para a revolução é o impulso que Walter Benjamin identifica no surrealismo:

...onde estão os pressupostos da revolução? Na transformação das opiniões ou na transformação das relações externas? É essa a questão capital, que determina a relação entre a moral e a política e que não admite qualquer camuflagem. Os surrealistas se aproximam cada vez mais de uma resposta comunista a essa pergunta. O que significa: pessimismo integral. Sem exceção.

\footnotetext{
${ }^{559}$ Pós-Modernismo - A lógica Cultural do Capitalismo Tardio. São Paulo: Ática, 1996, p. 48.

${ }^{560}$ No original: There was something about Langley's worldview, firmly in place at his birth, though perhaps polished to a shine at Columbia College, that would confer godlike immunity to such an ordinary fate as death in a war: it was innocents who died, not those born with the strength of no illusions.
} 
Desconfiança acerca do destino da literatura, desconfiança acerca do destino da liberdade, desconfiança acerca do destino da humanidade europeia, e principalmente desconfiança, desconfiança e desconfiança com relação a qualquer forma de entendimento mútuo: entre as classes, entre os povos, entre os indivíduos ${ }^{561}$.

No pessimismo concentrado de Homer \& Langley pode haver uma semente de contestação. No mundo administrado, a própria renúncia à falsa felicidade tem um conteúdo subversivo $^{562}$. A tentativa de dar forma à condição de pessimismo derivada da ausência de projetos coletivos que proponham uma alternativa ao capitalismo está por trás da leitura que Doctorow propõe nesse romance da história real dos irmãos Collyer. A tentativa de lastrear o pessimismo dos personagens do romance na história do século XX indica o trabalho da figuração. A ênfase, que espero ter ficado clara na minha exposição, nos eventos históricos e nas suas consequências na vida dos personagens despe a história dos irmãos Collyer de seu caráter meramente anedótico para revesti-la de conteúdo alegórico.

\section{Testemunhas da história - agência e determinação em tempos sombrios}

${ }^{561}$ BENJAMIN, WALTER. O surrealismo. O último instantâneo da inteligência europeia. In: Magia e Técnica, Arte e Política - Ensaios sobre literatura e história da cultura. São Paulo: Brasiliense, 1994, pp. 33-34.

562 “...a porção de alegria que a ordem social concede a suas vítimas alimenta-se da perpetuação da miséria. Por isso, a mera renúncia à falsa felicidade tem hoje em dia um efeito subversivo" (ADORNO, Theodor W. Prismas: crítica cultural e sociedade. São Paulo: Ática, 1998, p. 107). A sensibilidade de escritor que concebe a literatura como uma forma de conhecimento e de intervenção no mundo leva Cristovão Tezza a chegar a uma formulação próxima a do filósofo: "a ideia de felicidade supõe alguma adequação, algum equilíbrio entre o ser e o seu meio" (TEZZA, Cristovão. O espírito da prosa - uma autobiografia literária. Rio de Janeiro, São Paulo: Record, 2012, p. 84). 
Se Doctorow é, como Fredric Jameson o definiu, o "poeta épico do desaparecimento do passado radical americano ${ }^{563}$ ", Homer e Langley são seus personagens mais descrentes no poder de mudança da ação política. Eles testemunham uma sucessão de eventos trágicos que vão moldando a visão de mundo desencantada que se expressa no romance, como vimos, de diversas formas: na Teoria das Substituições de Langley, no seu "desespero filosófico", no crescente isolamento dos dois irmãos e na gradual perda das ilusões do narrador.

O gesto de isolamento dos irmãos Collyer filia-se a um conjunto de manifestações de recusa à sociedade capitalista, que variam em grau de subversão mas que expressam um comum desejo utópico de viver um mundo diferente. $\mathrm{O}$ crescente desencanto que faz Homer e Langley irem se isolando cada vez mais ao longo da narrativa guarda semelhanças com, por exemplo, o "olhar de pânico ${ }^{564 "}$ que Theodor Adorno identifica no romance Admirável Mundo Novo, de Aldous Huxley:

...impotente na maquinaria das relações mercantis que se desenvolvem por todos os lados e se tornam o único parâmetro, o intelectual reage ao choque com pânico. O "Brave New World" de Huxley é o sedimento desse pânico, ou melhor, sua racionalização ${ }^{565}$

Sabemos, pelo narrador, que a "contrariedade" (contrarianism, no original) de Langley só evolui. O próprio narrador, como vimos, também vai se despindo de suas esperanças ao longo da narrativa. Há no romance um esforço sistemático de dar forma, por meio da criação desses dois personagens, a um estado de descrença nas possibilidades de mudança radical da sociedade que é marca do nosso momento histórico. O desejo de separação $^{566}$ dos Collyer no romance poderia ter sido construído em torno de uma desilusão amorosa ou de problemas de relacionamento, de traumas familiares, de uma idiossincrasia dos personagens ou de algum tipo de condição psiquiátrica ou até da soma

${ }^{563}$ JAMESON, Fredric. Pós-Modernismo - A lógica Cultural do Capitalismo Tardio. São Paulo: Ática, 1996, p. 51.

${ }^{564}$ ADORNO, Theodor. Prismas: crítica cultural e sociedade. São Paulo: Ática, 1998, p. 93.

${ }^{565}$ Idem, p. 92.

566 No romance, os próprios personagens se definem como "Os Collyer - separatistas por princípio, reclusos" (p. 162). No original: The Collyers—principled separatists, recluses. 
de alguns desses fatores. No entanto, no livro não há outra explicação dada para o isolamento dos irmãos que não seja seu crescente desencanto com o mundo nascido e alimentado pela história. A presença sistemática de eventos históricos (como mostrei há pouco) apoia essa explicação. O separatismo dos Collyer dá forma há uma estrutura de sentimentos, um desejo por algo novo - a recusa sendo, na ausência de alternativas claras - a forma que esse desejo pode assumir.

$$
* * *
$$

Há, nesse romance, importantes questões de representação da História - tema recorrente nas obras de Doctorow - sugeridas pela figura do narrador cego, que vive trancado em casa e que gradualmente perde também a audição. Homer descreve o processo que o levou ao isolamento completo:

Se tivesse perdido o último sentido que me ligava ao mundo subitamente, eu teria gritado de horror e encontrado o modo mais rápido possível de dar cabo da minha vida. Mas me pegou gradualmente, permitindo-me graus progressivos de aceitação, com a esperança de que cada grau de perda seria o último, até que, no silêncio crescente de meu desespero, resolvi aceitar meu destino, tomado por um estranho impulso de descobrir como seria a vida quando meu ouvido tivesse sumido completamente e, sem visão ou som, eu só tivesse minha consciência para me divertir ${ }^{567}$ (p. 199).

Ao passo que a narrativa - que segue os eventos históricos do século $\mathrm{XX}$, lembremos - se desenrola, o narrador vai se separando do mundo e, consequentemente, de seu papel de testemunha da história: "Sou grato por ter esta máquina de escrever e as resmas de papel ao lado de minha cadeira, no momento em que o mundo fechou

\footnotetext{
${ }^{567}$ No original: If it had happened all of a sudden that I was to lose the last sense that connected me to the world, I would have screamed in terror and found some way as quickly as possible to end my life. But it came upon me gradually, allowing me progressive degrees of acceptance, with hope that every degree of loss would be the last, until, in the growing quiet of my despair, I resolved to accept my fate, having been taken by an odd impulse to find out what life would be like when my hearing was completely gone and, without sight or sound, I had only my own consciousness to amuse me.
} 
lentamente sua objetiva, tencionando deixar para mim apenas minha consciência ${ }^{568 \%}$. (p. 155)

O tempo, o esgotamento e perda da audição - somados, naturalmente, à condição inicial de cegueira - vão acumulando obstáculo ao poder de precisão do relato que o narrador constrói, como é perceptível no trecho:

Não sei ao certo quando nossas batalhas com o Departamento de Saúde, com o Corpo de Bombeiros, com o banco, com os serviços públicos e todo mundo mais que exigia alguma satisfação atraíram a atenção da imprensa. Não vou pretender uma precisão de lembrança enquanto relato nossa vida nesta casa nos últimos anos. O tempo parece para mim uma maré, um escorrer de areia. E minha mente escorre com ele. Estou me esgotando. Sinto que não tenho o lazer para me exigir quanto à data exata, a palavra exata. $\mathrm{O}$ que posso fazer é colocar as coisas à medida que me ocorrem e esperar pelo melhor. O que é uma vergonha, pois mantendo-me aplicado nesta tarefa eu desenvolvi um gosto por uma descrição exata de nossas vidas, vendo e ouvindo com palavras, se não com nada mais além delas ${ }^{569}$. (p. 200)

Beatriz Sarlo identifica uma forte presença do relato em primeira pessoa nos estudos sobre o passado a partir da década de 70. Ela descreve esse fenômeno como uma "guinada subjetiva". Vejamos:

Tomando-se em conjunto essas inovações, a atual tendência acadêmica e do mercado de bens simbólicos que se propõe a reconstituir a textura da vida e a verdade abrigadas na rememoração da experiência, a revalorização da primeira pessoa como ponto de vista, a reivindicação de uma dimensão subjetiva, que hoje se expande sobre os estudos do passado e os estudos culturais do presente, não são surpreendentes. São passos de um programa que se torna explícito, porque há condições ideológicas que o sustentam. Contemporânea do que se chamou nos anos 1970

\footnotetext{
${ }^{568}$ No original: I am grateful to have this typewriter, and the reams of paper beside my chair, as the world has shuttered slowly closed, intending to leave me only my consciousness.

${ }^{569}$ No original: I'm not sure when our battles with the Health and Fire Departments, the bank, the utilities, and everyone else who was demanding some kind of satisfaction attracted the notice of the press. I will not pretend to a precision of remembrance as I try to tell of our life in this house in these last few years. Time seems to me a drift, a shifting of sand. And my mind is shifting with it. I am wearing away. I feel I have not the leisure to tax myself for the right date, the right word. The best I can do is put things down as they occur to me and hope for the best. Which is a shame for as I've kept to this task I've developed a taste for an exact rendering of our lives, seeing and hearing with words if with nothing else.
} 
e 1980 de "guinada linguística" ou muitas vezes acompanhando-a como sua sombra, impôs-se guinada subjetiva ${ }^{570}$.

Um narrador cego, que pouco sai de casa, que vai perdendo a audição até ficar totalmente surdo e que passa a viver trancado num quarto não se qualifica como a testemunha mais confiável de nada. Creio haver, na figura desse narrador, um comentário sobre a dificuldade do relato subjetivo de construir visões totalizantes. A armadilha narrativa criada nesse romance, que vai prendendo o narrador em círculos de percepção cada vez mais escuros, sugere a insuficiência do relato em primeira pessoa de dar conta das complexas tramas da História. Quem sabe, e aqui me aventuro na zona insegura da especulação, há na construção desse narrador um indício do esgotamento de um modelo literário e o prenúncio de uma nova guinada.

Doctorow, autor maduro e consciente da relação da literatura com os problemas de seu tempo, fala da inquietação de se escrever ficção em um tempo no qual histórias individuais não se mostram mais capazes de figurar o destino coletivo:

The unsettling experience in writing fiction now may be finding that the story of any given individual, and I don't care who it is, may not be able to sustain an implication for the collective fate. There's a loss of consequence, that's what I mean. The assumption that makes fiction possible, even Modernist fiction - the moral immensity of the single soul - is under question ${ }^{571}$.

O romance aqui estudado parece tratar dessa "perda de consequência" na figura do narrador cuja percepção do mundo vai decrescendo com o andar do século e é totalmente comprometida no final do romance, que coincide com o começo dos anos $80^{572}$, década de profundas mudanças na configuração política e econômica mundial, como o crescimento do neoliberalismo e sua ênfase na ação individual em detrimento da mobilização coletiva (veja a guerra de Margareth Thatcher contra as organizações de

\footnotetext{
${ }^{570}$ SARLO, Beatriz. Tempo passado - cultura da memória e guinada subjetiva. São Paulo: Companhia das Letras; Belo Horizonte: Editora UFMG, 2007, p. 18.

${ }^{571}$ In: MORRIS, op. cit., p. 66.

572 Como mostrado, o último evento histórico mencionado no romance antes do isolamento completo dos Collyer é de 1980.
} 
trabalhadores) e, no final da década, a queda do Muro de Berlim, que para muitos simboliza o fim do socialismo ${ }^{573}$.

O conceito da História como repetição que move os projetos de Langley (o jornal em edição única para todos os tempos e a Teoria das Substituições) é constantemente desafiado pelos eventos históricos que vão surgindo com urgência e surpresa no enredo. Tal teoria e tal projeto devem ser lidos, como espero ter deixado claro, não como um empreendimento intelectual sério, mas como uma expressão do descontentamento de seu autor com o andar da história e de um desejo de compreensão. A impossibilidade de se fixar a história é notada pelo narrador, que caracteriza o projeto de seu irmão como um “eterno e inatingível jornal platônico" (p. 196).

A tensão entre o projeto de Langley de "fixar a vida americana" (p. 60) e os fatos do complexo século XX que não se deixam fixar, somada às questões de representação figuradas nos graus crescentes de perda da percepção do narrador monta uma equação que traduz formalmente alguns dos impasses do pensamento sobre a História hoje. A coleção de artefatos da vida americana que Homer e Langley reúnem em sua vida de observadores da História pede para ser compreendida, como se a vida dos Collyer fosse "um museu, embora com nossas riquezas ainda não catalogadas, a curadoria ainda por vir" (p. 199).

\footnotetext{
573 "Na década de 80, uma direita vitoriosa passou à ofensiva. No mundo anglo-saxônico, os regimes Reagan e Tchatcher, depois de anularem o movimento operário, fizeram recuar a regulamentação e a redistribuição. Espalhando-se da Grã-Bretanha para o resto da Europa, a privatização do setor público, os cortes nos gastos sociais e altos níveis de desemprego criaram um novo padrão de desenvolvimento neoliberal, por fim adotado tanto por partidos de esquerda quanto de direita. No final da década, a missão social-democrata do pós-guerra na Europa Ocidental - o bem-estar social baseado no pleno emprego e no abastecimento geral - tinha sido abandonada pela Internacional Socialista. Na Europa Oriental e na União Soviética, o comunismo - incapaz de competir economicamente no exterior ou de se democratizar em casa - foi completamente destroçado. No Terceiro Mundo, Estados nascidos de movimentos de libertação nacional foram pegos por toda a parte na armadilha das novas formas de subordinação internacional, incapazes de escapar às pressões dos mercados financeiros mundiais e de suas instituições supervisoras". (ANDERSON, Perry. As origens da Pós-Modernidade. Rio de Janeiro: Jorge Zahar, 1999. pp. 107-8).
} 
É possível que o fenômeno que aqui estou descrevendo na obra de Doctorow - qual seja, a tendência dos romances formalmente complexos serem também cognitivamente relevantes, enquanto os romances que aderem a formas tradicionais de narração (comoWelcome to Hard Times, World's Fair, Billy Bathgate, The Waterworks, The March e Homer \& Langley) tendem a apresentar uma menor consciência da forma e uma transfiguração fraca das tensões sociais de seu tempo. Talvez possamos hoje empregar nos estudos literários a descrição que Adorno faz da nova música (Schoenberg, Webern e Berg) como uma forma artística mais verdadeira por incorporar a irresolução das tensões em sua construção formal e recusar a harmonia. Para Adorno, a nova música "assume contra sua própria vontade uma posição precisa quando renuncia ao engano da harmonia, engano que se tornou insustentável frente a uma realidade que está marchando para a

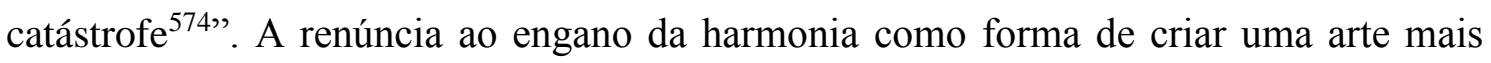
próxima ao mundo atual tem em The Book of Daniel e Ragtime traduções literárias prolíficas em potencial crítico, como espero ter demonstrado nessa tese.

${ }^{574}$ ADORNO, T. W. Filosofia da nova música. São Paulo: Editora Perspectiva, 1989, p. 105. 


\section{Considerações finais}

O processo de compreensão crítica da obra desse importante romancista contemporâneo impôs escolhas que determinaram os caminhos aqui seguidos. Outros caminhos de interpretação seguem abertos e tenho a esperança de tê-los apontado de forma a convidar caminhadas mais longas.

A opção, aqui seguida, pelo estudo das possibilidades críticas da forma nas obras analisadas ajudou-me a perceber o potencial - e o desejo latente - do romance de recriarse no necessário empenho de desenvolver formas de consciência histórica que nos auxiliem na compreensão da história como um processo não alheio à vontade humana.

As obras aqui estudadas mostram como o romance continua a ser um poderoso instrumento de diagnóstico do social. Além das admiráveis qualidades estéticas, esses textos interessaram-me pelo engajamento franco com a História e com as dificuldades do processo de representação. Como vimos ao longo da tese, o empreendimento da representação da história é explicitamente mencionado nos três romances, o que mostra a importância desse tema na obra de Doctorow. No entanto, maior aprendizado é obtido quando os impasses da representação são assimilados pela forma, tornando-se parte dela. Esses momentos são instrutivos por explicitar a relação entre história e forma - existente em toda obra de arte e perseguida nessa tese - de modo que a forma conte a história e, ao fazê-lo, faça presentes abalos vividos e esperados, como um verdadeiro "sismógrafo da realidade ${ }^{575}$,

Assim, o ethos ambivalente do narrador e o trânsito irregular entre vários modos textuais (tese, memórias, narrativa) em The Book of Daniel configuram em forma uma crise histórica. A sintaxe cumulativa e a linguagem que parodia o pretenso distanciamento do discurso historiográfico em Ragtime registram uma intuição sobre as limitações da escrita frente ao processo de representação em crise. O retorno a formas narrativas convencionais e o deslocamento do problema da representação para o nível do tema em Homer \& Langley são sintomas de um recuo e de um timidez da forma frente a um mundo

\footnotetext{
575 ADORNO, Theodor. Introdução à Sociologia da Música - Doze preleções teóricas. São
} Paulo: Editora Unesp, 2011, p. 339. 
cada vez menos cognoscível. Esse romance de 2009 não carrega explicitamente na forma os impasses da representação, como o fazem os dois romances da década de 70. Em vez disso, ele tematiza a própria História e suas crises na forma de um tímido protesto e de um prolongado suspiro de agonia.

Cada um dos romances aqui estudados impôs um desafio interpretativo próprio. O trabalho de análise e interpretação da qual resultou a tese me ensinou a trilhar diferentes caminhos críticos e a buscar mediações que ajudassem a ligar os fios soltos do texto. Todo esse trabalho é mais evidente no capítulo 1, o que demandou mais trabalho pela dificuldade da obra estudada.

A leitura atenta de Ragtime reforçou minha desconfiança de generalizações e categorias interpretativas amplas. $\mathrm{O}$ embate com a obra reforçou em mim a convicção de que passos demorados e reflexivos podem levar longe. Assim, segui na leitura a advertência trazida pela epígrafe do romance: "Do not play this piece fast".

A primeira leitura de Homer \& Langley não me convenceu do interesse crítico da obra. Leituras subsequentes me mostraram que um romance formalmente conservador pode trazer lições sobre forma (a própria timidez formal sendo instrutiva) tanto quanto romances ousados como The Book of Daniel e Ragtime.

Em conjunto, as três leituras me mostraram que a observação crítica dos caminhos percorridos pela obra de um escritor consciente da forma como E. L. Doctorow pode revelar tendências da produção artística de toda uma época. No caso de Doctorow, vejo uma preferência cada vez maior - novamente confirmada pela publicação, há poucas semanas, de Andrew's Brain - por uma narrativa mais convencional (como vimos na introdução) e o deslocamento de questionamentos e impasses para o nível do tema. É claro que só um estudo comparativo de obras e autores diferentes ao longo de um período pode confirmar essa tendência, mas o estudo de autores específicos é útil no esboço de tendências gerais. 
Uma última lição - talvez a de maior potencial formativo - aprendida no processo de escrita da tese foi a de que o trabalho crítico consequente implica em riscos. A inserção institucional da tese - em última análise, ela é escrita "como parte dos pré-requisitos para a obtenção do título de Doutor" - atua como força inibidora do exercício crítico ousado. Essa força age sutilmente, sugerindo caminhos críticos seguros e a busca de apoio na teoria solidamente constituída e institucionalmente inserida. É possível que haja traços da atuação dessa força na tese aqui apresentada - já que não se desaprendem facilmente hábitos adquiridos por anos de aprendizado -, mas minha opção foi por assumir os riscos de erro inerentes ao trabalho crítico que se debruça sobre o complexo, o indefinido e o aberto. $\mathrm{O}$ encorajamento e o apoio dado por minha orientadora ajudou-me a seguir esse caminho. 


\section{Referências bibliográficas:}

AARONOWITZ, Stanley. False Promises: a History of the Working Class in the United States. Durham, Duke University Press, 1992.

ADORNO, Theodor. Filosofia da nova música. Tradução de Magda França. 2. ed. São Paulo: Editora Perspectiva, 1989.

- Introdução à Sociologia da Música - Doze preleções

teóricas. São Paulo: Editora Unesp, 2011. Tradução de Fernando R. de Moraes Barros.

2003. Tradução de Jorge M. B. de Almeida.

- Notas de Literatura I. São Paulo: Duas Cidades; Ed. 34, - Posição do narrador no romance contemporâneo. In: BENJAMIN, Walter; HORKHEIMER, Max; ADORNO, Theodor \& HABERMAS, Jürgen. Textos escolhidos. São Paulo: Abril Cultural, 1983.

1998.

. Prismas: crítica cultural e sociedade. São Paulo: Ática,

ALBINO, C.; LIMA, S. R. A., C. O percurso histórico da improvisação no ragtime e no choro. Per Musi, Belo Horizonte, n.23, 2011.

ALCMENO, Bastos. Introdução ao Romance Histórico. Rio de Janeiro: Ed. UERJ, 2007.

ANDERSON, Perry. As origens da Pós-Modernidade. Rio de Janeiro: Jorge Zahar, 1999. . A crise da crise do marxismo. São Paulo: Brasiliense, 1985.

- Trajetos de uma forma literária. Revista Novos Estudos CEBRAP, número 77, março de 2007.

APPIGNANESI, Richard; XARATE, Oscar. Introducing Freud. London: Icon Books, 2007.

BASTOS, Alcmeno. Introdução ao romance histórico. Rio de Janeiro: EDUERJ, 2007. 
BAUDRILLARD, Jean. Simulacros e Simulação. Lisboa: Relógio D’Àgua, 1991. Tradução de Maria João da Costa Pereira.

BENJAMIN, Walter. Magia e Técnica, Arte e Política - Ensaios sobre literatura e história da cultura. São Paulo: Brasiliense, 1994. Tradução de Sérgio Paulo Rouanet. . The Arcades Project.Cambridge (USA), London: Harvard University Press, 1999. Traduzido por Howard Eiland e Kevin Mclaughlin.

BENVENISTE, Émile. Problemas de linguística geral I. Campinas: Pontes, 1995 Tradução de Maria da Glória Novak e Maria Luísa Neri.

BUHLE, Paul. Marxism in the United States.London, Verso, 1991.

CAMARgo, Iná Costa. Prefácio de Companhia do Latão - 7 peças. In: CARVALHO, Sérgio de, MARCIANO, Márcio. Companhia do Latão - 7 peças. São Paulo: Cosac Naify, 2008.

CÂNDIDO, Antônio. Literatura e Sociedade. Rio de Janeiro: Ouro sobre Azul, 2006. . Radicalismos. Estud. av., Abr 1990, vol.4, no.8, pp. 4-18.

CARR, Edward. What is History? New York: Random House, 1961.

COOVER, Robert.The Public Burning. New York: Grove Press, 1997.

DAVIS, Mike. Planeta Favela. São Paulo: Boitempo, 2006. Tradução de Beatriz Medina. . Prisoners of the American Dream. London, Verso, 1990.

DE GROOT, Jerome. Consuming History: historians and heritage in contemporary popular culture. New York: Routledge, 2009. . The Historical Novel. London, New York: Routledge, 2010.

DENNIG, Michael. The Cultural Front - The Laboring of American Culture in the Twentieth Century. New York, London: Verso, 1997.

DIGGINS, John Patrick. The Rise and Fall of the American Left. New York, London: W.W. Norton \& Company, 1992.

DOS PASSOS, John. A Great American. The New Masses, 1, dezembro de 1927. What makes a novelist. In: National Review, 20, 1968. 
EAGLESTONE, Robert. Contemporary Fiction. Oxford: Oxford University Press, 2013.

EAGLETON, Terry. Ideology: an introduction. London; New York: Verso, 1991.

California Press, 1976.

Marxism and literary criticism. Berkeley: University of

FAST, Howard. PeekSkill USA - Inside the infamous 1949 riots. New York: Dover, 2006.

. The World of Langley Collyer. In: The New Masses, April 22, 1947.

FOLEY, Barbara. Fact, Fiction, and "Reality". Contemporary Literature, Vol. 20, No. 3 (Summer, 1979), pp. 389-399. University of Wisconsin Press. http://www.jstor.org/stable/1208301.

- Radical Representations - Politics and Form in U.S.

Proletarian Fiction, 1929-1941. Durham, London: Duke University Press, 1993.

GARGANO, James. The Question of Poe's Narrators. College English, Vol. 25, No. 3 (Dec., 1963), National Council of Teachers of English. http://www.jstor.org/stable/373684. Acesso em: 29 de Setembro de 2013)

GRAHAM, Helen. The Spanish Civil War: A Very Short Introduction. New York:Oxford University Press, 2005.

GRAUSAM, Daniel. On Endings: American Postmodern Fiction and the Cold War. Charlottesville: University of Virginia Press, 2011.

HARVEY, David. Condição pós-moderna.São Paulo: Loyola, 1992.

HEDGES, Chris. Let's Get This Class War Started. Truthout, Monday, 21 October 2013. http://www.truth-out.org/opinion/item/19527-lets-get-this-class-war-started (Acesso em 29/12/2013)

HEMINGWAY, Ernest. For Whom the Bell Tolls. St. Albans: Triad/Panther Books, 1976.Em português: Por quem os sinos dobram. São Paulo: Companhia Editora Nacional, 1969. Tradução de Monteiro Lobato.

HOBSBAWM, Eric. A Era dos Impérios (1875-1914). São Paulo: Paz e Terra, 2011. . Sobre História. São Paulo: Companhia das Letras, 1998.

York: Vintage Books, 1996.

. The Age of Extremes - A History of the World, 1914-1991. New 
HOLLOWELL, John. Fact and Fiction: The New Journalism and the Nonfiction Novel. Chapel Hill, N. C.: Univ. of North Carolina Press, 1977.

HOMER, Sean, KELLNER, Douglas. Fredric Jameson: a critical reader. New York: Palgrave Macmillan, 2004.

HOPKINS, Michael F. The Cold War. London: Thames \& Hudson, 2011.

HOWE, Irving. Problems in the 1960s In: JUMONVILLE, Neil (ed.) The New York intellectuals reader. New York: Routledge, 2007.

HUTCHEON, Linda. A Poetics of Postmodernism. New York: Routledge, 1988. . Historiographic Metafiction: Parody and the Intertextuality of History. $\quad$ p. $11 . \quad$ Disponível em <https://tspace.library.utoronto.ca/bitstream/1807/10252/1/TSpace0167.pdf > (acessado em 20/02/2012).

JAMESON, Fredric. A cultura do dinheiro. Petrópolis: Vozes, 2001. Tradução de Maria Elisa Cevasco e Marcos César de Paula Soares.

. As marcas do visível. Rio de Janeiro: Graal, 1995.

- Marxism and Form - twentieth-century dialectical theories of literature. Princeton: Princeton University Press, 1971.

. PMLA, Vol. 86, No. 1 (Jan., 1971), pp. 9-18. Modern Language Association, p. 9. http://www.jstor.org/stable/460996 Acesso em: 27 de Setembro de 2013.

Estudos - CEBRAP, número 77, 77, março de 2007.

. Pós-Modernismo - A lógica Cultural do Capitalismo Tardio.

São Paulo: Ática, 1996. Tradução de Maria Elisa Cevasco.

- Periodizing the 60s. In: JAMESON, Fredric. The Ideology of Theory - Essays 1971-1986 - Volume 2: The Syntax of History. Minneapolis: University of Minnesota Press, 1988.

- Representing Capital. London, New York: Verso, 2011.

. The Geopolitical Aesthetic: Cinema and Space in the World System. London: BFI Publications, 1992. 
. The Political Unconscious: Narrative as a Socially Symbolic Act. Ithaca, N.Y.: Cornell University Press; London: Methuen, 1981. O Inconsciente Político: A narrativa como ato socialmente simbólico. São Paulo: Ática, 1992. Tradução de Valter Lellis Siqueira e revisão da tradução de Maria Elisa Cevasco.

Spirit.London, NewYork: Verso, 2010.

- The Hegel Variations: On the Phenomenology of

JUMONVILLE, Neil (ed.) The New York intellectuals reader. New York: Routledge, 2007.

KAZIN, Michael. American Dreamers - How the Left changed a nation. New York: Vintage Books, 2012.

KOCH, Stephen. Ponto de Ruptura - Hemingway, John dos Passos e o Assassinato de José Robles.São Paulo: Difel, 2008.

LEWIS, Barry. Postmodernism and Literature. In: SIM, Stuart (Editor). The Routledge Companion to Postmodernism. Routledge: New York, London, 2001.

LIDZ, Franz. Ghosty Men - The Strange but True Story of the Collyer Brothers, New York's Greatest Hoarders. New York: Bloomsbury, 2003.

LOWY, Michel. As aventuras de Karl Marx contra o Barão de Munchhhausen: marxismo e positivismo na sociologia do conhecimento. São Paulo: Cortez, 1994.

- Walter Benjamin: aviso de incêndio - uma leitura das teses "Sobre o conceito de história”. São Paulo: Boitempo, 2005. Tradução de Wanda Nogueira Caldeira Brant.

2005.

- Franz Kafka, sonhador insubmisso. Rio de Janeiro: Azougue,

LUKÁCS, Georges. O Romance Histórico. São Paulo: Boitempo, 2011. Tradução de Rubens Enderle.

- A Teoria do Romance. São Paulo: Duas Cidades, Editora 34, 2000. Tradução de José Marcos Mariani de Macedo.

MARX, KARL. O 18 Brumário e Cartas à Kugelmann. Rio de Janeiro: Paz e Terra, 1997.

MAILER, Norman. The Armies of the Night-History as a Novel, The Novel as History. New York: Penguin, 1994.

NAVES, Rodrigo. A Forma Difícil. São Paulo: Ática, 1996. 
PODHORETZ, Norman, "My Negro Problem-And Ours," Commentary vol. 35, no. 2, February 1963.

QUATTROCCHI, Angelo; NAIRN, Tom. O Começo do Fim - França, Maio de 68. Rio de Janeiro: Record, 1998. Tradução de Marcos Aarão Reis.

RIIS, Jacob. How the other half lives - studies among the tenements of New York. New York: Penguin Books, 1997.

SARLO, Beatriz. Tempo passado - cultura da memória e guinada subjetiva. São Paulo: Companhia das Letras; Belo Horizonte: Editora UFMG, 2007. Tradução de Rosa Freire d'Aguiar.

SARTRE, Jean-Paul. Situações I - crítica literária. São Paulo: CosacNaify, 2005 (tradução de Cristina Prado e Bento Prado Jr.).

SAVVAS, Theophilus. American Postmodernist Fiction and the Past. London: Palgrave Macmillan, 2011.

SCHNEIR, Walter. Final Verdict - What really happened in the Rosenberg Case. New York: Melville House Publishing, 2010.

SCHWARZ, Roberto. Que horas são? São Paulo: Cia. das Letras, 1988.

SOUSA, Rodrigo Farias de. A Nova Esquerda Americana - De Port Huron aos Weathermen (1960-1069). Rio de Janeiro: Editora FGV, 2009.

STANSELL, Christine. American Moderns - Bohemian New York and the Creation of a New Century. New York: Metropolitan Books, 2000.

STALLABRASS, Julian. Gargantua: manufactured mass culture. London; New York: Verso, 1996.

STROUT, Cushing. Reconsidering the Rosenbergs: History, Novel, Film. Reviews in American History, Vol. 12, No. 3 (Sep., 1984), pp. 309-321. The Johns Hopkins University Press. http://www.jstor.org/stable/2702238. Acesso em: 16 de Junho de 2013.

TERTULIAN, Nicolas. Georg Lukács - Etapas de seu pensamento estético. São Paulo: Editora Unesp, 2008.

TEZZA, Cristovão. O espírito da prosa - uma autobiografia literária. Rio de Janeiro, São Paulo: Record, 2012.

TROTSKY, Leon. A Revolução Traída. São Paulo: Global Editora, 1980.http://www.marxists.org/portugues/trotsky/1936/revolucaotraida/index.htm 
WALD, Alan. Writing from the Left. London: Verso, 1994.

WEBB, Charles. The Graduate. New York: RosettaBooks, 2011.

WEINSTEIN, James. Ambiguous Legacy -The Left in American Politics. New York: New Viewpoints, 1975.

WHITE, Hayden. Meta-História: A Imaginação Histórica do Século XIX. São Paulo: Editora da Universidade de São Paulo, 2008. Tradução de José Laurêncio de Melo.

. The Content of the Form - Narrative Discourse and Historical Representation. Baltimore: The Johns Hopkins University Press, 1992.

WILLIAMS, Raymond. Palavras-Chave - um vocabulário de cultura e sociedade. São Paulo: Boitempo, 2007. Tradução de Sandra Guardini Vasconcelos.

York: Routledge, 1974. - Television: Technology and cultural form.London New

WRENN, John H. John dos Passos. Rio de Janeiro: Editora Lidador, 1966.

ZINN, Howard. A People's History of the United States. New York: Harper \& Row, 1980.

\section{Obras de E. L. Doctorow:}

DOCTOROW, E. L. Andrew's Brain. New York: Random House, 2014. . Billy Bathgate. New York: Random House, 2010. . Big as Life. New York: Simon and Schuster, 1966.

Random House, 2007.

Creationists - selected essays (1993-2006). New York: 
. City of God: A Novel.New York: Random House, 2000. Em português: Deus, um fracasso amoroso. São Paulo, Rio de Janeiro: Editora Record, 2003. Tradução de Roberto Muggiati. Revisão da Tradução de Moacyr Scliar.

. Drinks before Dinner: A Play. New York: Random House, 1979.

- False Documents. In: TRENNER, Richard. E.L.Doctorow Essays and Conversations. Princeton, New Jersey: Ontario Review Press, 1983.

- Homer \& Langley. New York: Random House, 2010. Em português: Homer \& Langley. Rio de Janeiro: Record, 2011. Tradução de Roberto Muggiati.

- Jack London, Hemingway, and the Constitution: Selected Essays, 1977-1992. New York: Random House, 1993.

. Loon Lake. New York: Random House, 2007.

Lives of the Poets: Six Stories and a Novella. New York:

Random House, 1984.

Ragtime. New York: Random House, 2007. Em português: Ragtime. Rio de Janeiro: BestBolso, 2007. Tradução de A. Weissenberg.

University Press, 2003.

- Reporting the Universe.Cambridge, London: Harvard . Sweet Land Stories. New York: Random House, 2004.

. The Book of Daniel. New York: Random House, 2007.Em português: O Livro de Daniel. Rio de Janeiro: Record, 1971. Tradução de Áurea Weissenberg.

. The March. New York: Random House, 2006. Em português: A Marcha. São Paulo, Rio de Janeiro: Editora Record, 2007. Tradução de Roberto Muggiati. Revisão da Tradução de Moacyr Scliar.

. The Waterworks. New York: Random House, 1994. Em português: A mecânica das águas. São Paulo: Companhia das Letras, 1995. Tradução de Paulo Henriques Britto.

2003.

. Three screenplays.Baltimore: Johns Hopkins University Press, 
- Welcome to Hard Times. New York: Random House, 1975.

Em português: Tempos Difíceis. Rio de Janeiro: Record, S/D. Tradução de Áurea Weissenberg.

World's Fair. New York: Random House, 2007.Em português: A Grande Feira. São Paulo: Companhia das Letras, 1988. Tradução de Aulyde Soares Rodriguês e João Moura JR.

\section{Estudos sobre a obra de E. L. Doctorow:}

AGILDO, João Rodrigo Lima. A crise da esquerda norte-americana em "The Book of Daniel"', de E. L. Doctorow. 2006. 92f. Dissertação (Mestrado emEstudos Linguísticos e Literários em Inglês) - Faculdade de Filosofia, Letras e Ciências Humanas, Universidade de São Paulo, São Paulo, 2006.

ARNOLD, Marilyn. "History as Fate in E. L. Doctorow's Tale of a Western Town." South Dakota Review 18 (1980): 5 3-63. Reprinted in TRENNER, Essays and Conversations, 207-16.

BAKKER, J. “The Western: Can It Be Great?” Dutch Quarterly Review of AngloAmerican Letters 14, no. 2 (1984): 140-63.

BEVILACQUA, Winifred Ferrant. Narration and History in E.L. Doctorow's Welcome to Hard Times, Book of Daniel and Ragtime. Disponível em <http://rauli.cbs.dk/index.php/assc/article/viewFile/1444/1457>Acesso em : 10 de Fevereiro de 2012.

BLOOM, Harold. E.L. Doctorow's Ragtime. Philadelphia: Chelsea House, 2004.

BOLCOM, William. Ragtime. In: The New Grove: Gospel, Blues and Jazz. P. Olivier, M. Harrison e W. Bolcom, eds. London: Macmillan, 1986.

BRIENZA, Susan. "Doctorow's Ragtime: Narrative as Silhouettes and Syncopation." Dutch Quarterly Review of Anglo-American Letters 2, no. 3 (1981): 97-103. 
BUDICK, Emily M. Seeking the Shores of Self: E.L.Doctorow's Ragtime and the Moral Fiction of History. In: Fiction and Historical Consciosness: The American Romance Tradition. New Haven: Yale University Press, 1989.

CIABATTARI, Jane. Amid The Rubbish, Doctorow Finds Meaning. NPR.org, September 04, 2009. http://www.npr.org/templates/story/story.php?storyId=112447772 (Acesso em 11/11/2013).

CLAYTON, John. "Radical Jewish Humanism: The Vision of E. L. Doctorow." Fiction International 10 (1977):60-64. (Reprinted in TRENNER, Essays and Conversations, 109-11) .

COOPER, Barbara "The Artist as Historian in the Novels of E. L. Doctorow." Emporia State Research Studies 29, no. 2 (Fall 1980): 5-44.

CROWN, Sarah. E. L. Doctorow: "I don't have a style, but the books do". The Guardian, London, 23 de Janeiro de 2010, Culture, Books. Disponível em <http://www.guardian.co.uk/books/2010/jan/23/el-doctorow-homer-and-lamgley $>$. Acesso em : 01 de Junho de 2013.

DETWEILER, Robert. Carnival of Shame: Doctorow and the Rosenbergs. Religion and American Culture. A Journal of Interpretation, Vol. 6, No. 1, Special Issue: Religion and Twentieth-Century American Novels (Winter, 1996), pp. 63-85. University of California Press on behalf of the Center for the Study of Religion and American Culture. 〈http://www.jstor.org/stable/1123973 > Acesso em: 19 de Junho de 2012.

DOCTOROW, E.L. Interview by Diane Osen, National Book Foundation Archives. Availableonline<http://www.nationalbook.org/authorsguide_edoctorow2.html> Acessado em 14/05/2009.

EMBLIDGE, David. "Marching Backward into the Future: Progress as Illusion in Doctorow's Novels." Southwest Review (1977):397-409.

FOLEY, Barbara. From U.S.A. to Ragtime: Notes on the Forms of Historical Consciousness in Modern Fiction. In: TRENNER, Richard. E.L.Doctorow - Essays and Conversations. Princeton, New Jersey: Ontario Review Press, 1983.

FOWLER, Douglas. Understanding E. L. Doctorow. Columbia: University of South Carolina Press, 1992.

FRIEDL, Herwig, SCHULZ, Dieter, ed. E. L. Doctorow: A Democracy of Perception. Essen: Die Blaue Eule, 1988. 
FRIEDL, Herwig. "Power and Degradation: Patterns of Historical Process in the Novels of E. L. Doctorow" (in Friedl and Schultz, A Democracy of Perception, 1944).

GIRGUS, Sam. "In His Own Voice: E. L. Doctorow's The Book of Daniel” (in Friedl and Schultz, A Democracy of Perception, 75-90).

GIRGUS, Sam. "A True Radical History: E. L. Doctorow." The New Covenant: Jewish Writers and the American Idea. Chapel Hill: University of North Carolina Press, 1984; 160-83.

GROSS, David. "Tales of Obscene Power: Money and Culture, Modernism and History in the Fiction of E. L. Doctorow." Genre, no. 13 (1980):71-92. (Reprinted in TRENNER, Essays and Conversations, 120-50).

GUSSOW, Mel. "Novelist Syncopates History in 'Ragtime." New York Times, July $11,1975$.

HARRIS, Stephen. The fiction of Gore Vidal and E.L. Doctorow: writing the historical self. Oxford, New York: Peter Lang, 2002.

HARPHAM, Geoffrey Gait. "E. L. Doctorow and the Technology of Narrative." PLMA 100, no. 1(1985): 81-95.

HARTER, Carol C., THOMPSON, James R. E. L. Doctorow. Boston: Twayne Publishers, 1990.

ICKSTADT, Heinz. Plotting to what end? Doctorow, Coover and the Invention (s) of History. In: MACARRO, Antonia Sanches (ed.). Studies in American Literature. Valência: Universitat de València.

ICKSTADT, Heinz. Plotting to what end? Doctorow, Coover and the Invention ( $s$ ) of History. In: MACARRO, Antonia Sanches (ed.). Studies in American Literature. Valência: Universitat de València. Disponível em <http://books.google.com/books?hl=ptBR\&lr=\&id=uhUbyKVBHL8C\&oi $=$ fnd $\& p g=P A 251 \& d q=$ doctorow + novel \&ots $=$ SJ INGjYiu4\&sig=DeCt2knZld281lat5_YwALXIpJw\#PPP1,M1> (acessado em 10/04/2009).

JOHNSON, Diane. "The Righteous Artist: E. L. Doctorow." In Terrorists \& Novelists, edited by Diane Johnson, pp. 141-49. New York: Knopf, 1982.

KARL, Frederick R. On Ragtime's Variations. In: BLOOM, Harold. E.L. Doctorow's Ragtime. Philadelphia: Chelsea House, 2004. 
LECLAIR, Tom, MCCAFFERY, Larry. "A Spirit of Transgression," Anything Can Happen: Interviews with Contemporary American Novelists. Urbana: University of Illinois Press, 1983. (Reprinted in TRENNER, Essays and Conversations, 31-47.)

LEHMANN-HAUPT, Christopher. Ragtime. The New York Times, 08 de julho de 1975.

LEVINE, Paul. "A Multiplicity of Witness: E. L. Doctorow at Heidelberg." Symposium with Doctorow and students, Heidelberg 19 June 1985. Printed in Friedl and Schulz, A Democracy of Perceptions, 61-73.

. "The Writer as Independent Witness." Interview, March 1978, Canadian Broadcasting Corp. (Reprinted in TRENNER, Essays and Conversations, 57-69.)

. E. L. Doctorow. London and New York: Methuen, 1985.

. E. L.Doctorow. New York: Methuen. 1985.

LORSCH, S. E. "The Book of Daniel as Kunstlerroman: The Politics of Art." Papers in Language and Literature 18 (1982): 384-97.

LUBARSKY, Jared. "History and the Forms of Fiction: An Interview with E. L. Doctorow." Eiso Seinen[Tokyo] 124 (1978): 150-52.

MAYNES-AMINZADE, Liz. Rescuing the Past from History: E.L.Doctorow's Ragtime. Columbia Journal of Literary Criticism - Volume IV, Spring 2006.

MORARU, Christian. Rewriting: postmodern narrative and cultural critique in the age of cloning. Albany: State University of New York Press, 2001. Capítulo I da Parte II: "Romanticism Reincorporated: E. L. Doctorow and the (Re)Production of America".

MORRIS, Christopher D. (ed.) Conversations with E.L. Doctorow. Jackson: University Press of Mississippi, 1999.

- Models of Misrepresentation: On the Fiction of E. L. Doctorow. University Press of Mississippi. 1991.

NADEL, Alan. "Hero and Other in Doctorow's Loon Lake." College Literature 14, no. 2 (1987): $136-45$

NAVASKY, Victor. "E. L. Doctorow: 'I Saw a Sign." New York Times Book Review 28 September 1980,44-45. 
OSTENDORF, Berndt. On the Musical World. In: BLOOM, Harold. E.L. Doctorow's Ragtime. Philadelphia: Chelsea House, 2004.

PARKS, John G. The Politics of Polyphony: The Fiction of E. L. Doctorow. Twentieth Century Literature, Vol. 37, No. 4 (Winter, 1991), pp. 454-463 Published by: Hofstra http://www.jstor.org/stable/441658

. E. L. Doctorow. New York: Continuum. 1991.

PLIMPTON, George. "The Art of Fiction." Interview with E. L. Doctorow. Paris Review 101 (1986): 22-47.

REED, T.V. Genealogy/Narrative/Power: Questions of Postmodernity in Doctorow's The Book of Daniel. In: American Literary History 4, 1992.http://www.jstor.org/stable/489989.

SALTZMAN, Arthur. "The Stylistic Energy of E. L. Doctorow." In TRENNER, Essays and Conversations, 73-108.

SÁNCHEZ, Jesús Benito.Doctorow's Ragtime: A Breach in the Frame of History. Atlantis: Revista de la Asociación Española de Estudios Anglo-Norteamericanos, ISSN 0210-6124, Vol. 19, $\mathrm{N}^{\mathrm{o}}$ 2, 1997, pp. 15-24. Disponível em <http://www.atlantisjournal.org/Papers/v19\%20n2/v19\%20n2-2.pdf > acessado em 20/02/2012.

SCHRANK, Bernice. Getting the Picture: Radical Possibilities in Doctorow's "The Book of Daniel". Studies in American Jewish Literature (1981-), Vol. 12, THE CHANGING MOSAIC: FROM CAHAN TO MALAMUD, ROTH AND OZICK (1993), pp. 62-71. Penn State University. http://www.jstor.org/stable/41206178. Acesso em 20/02/2012.

SCHULZ, Dieter. "E. L. Doctorow's America: An Introduction to His Fiction" (in FRIEDL and Schulz, A Democracy of Perception, 9-18).

SEELYE, John. “Doctorow's Dissertation.” New Republic 174, no. 15 (1976): 21-3.

SIEGEL, Bem. ed. Critical Essays on E.L. Doctorow. New York: G.K. Hall \& Co., 2000.

STEINBERG, Cobbett. "History and the Novel: Doctorow's Ragtime". Denver Quarterly 10, no. 4 (1976): 125-30.

STROUT, Crushing. Historicizing Fiction and Fictionalizing History: The Case of E.L. Doctorow. In: Prospects 5, 1980. 
TANNER, Stephen L. "Rage and Order in Doctorow's Welcome to Hard Times." South Dakota Review 22, no. 3 (1984):79-85.

TOKARCZYK, Michelle M. E. L.Doctorow: An Annotated Bibliography. New York: Garland. 1988.

2000. . E. L. Doctorow's Skeptical Commitment. Peter Lang.

TRENNER, Richard (editor). E. L. Doctorow: Essays \& Conversations. Princeton, NJ: Ontario Review Press. 1983.

. "Politics and the Mode of Fiction." Ontario Review, no. 16 (Spring-Summer 1982): 5-16.

WEBER, Bruce. The Myth Maker. The New York Times, 20 de outubro de 1985.

WILLIAMS, John. Fiction as False Document: The Reception of E. L. Doctorow in the Postmodern Age. Boydell \& Brewer, Ltd. 1996.

\section{Romances de E. L. Doctorow em ordem cronológica}

\begin{tabular}{|l|l|}
\hline 1960 & $\begin{array}{l}\text { Welcome to Hard Times } \\
\text { Em portugues: Tempos Difíceis. Rio de Janeiro: Record, S/D. Tradução de } \\
\text { Áurea Weissenberg }\end{array}$ \\
\hline 1966 & $\begin{array}{l}\text { Big As Life } \\
1971\end{array}$ \\
$\begin{array}{l}\text { The Book of Daniel } \\
\text { O Livro de Daniel. Rio de Janeiro: Record, 1971. Tradução de Áurea } \\
\text { Weissenberg. }\end{array}$ \\
\hline
\end{tabular}




\begin{tabular}{|c|c|}
\hline 1975 & $\begin{array}{l}\text { Ragtime } \\
\text { Em português: Ragtime. Rio de Janeiro: BestBolso, 2007. Tradução de A. } \\
\text { Weissenberg. }\end{array}$ \\
\hline 1980 & Loon Lake \\
\hline 1985 & $\begin{array}{l}\text { World's Fair } \\
\text { Em português: A Grande Feira. São Paulo: Companhia das Letras, } 1988 . \\
\text { Tradução de Aulyde Soares Rodriguês e João Moura JR. }\end{array}$ \\
\hline 1989 & Billy Bathgate \\
\hline 1994 & $\begin{array}{l}\text { The Waterworks } \\
\text { Em português: A mecânica das águas. São Paulo: Companhia das Letras, } \\
\text { 1995. Tradução de Paulo Henriques Britto. }\end{array}$ \\
\hline 2000 & $\begin{array}{l}\text { City of God } \\
\text { Em português: Deus, um fracasso amoroso. São Paulo, Rio de Janeiro: Editora } \\
\text { Record, 2003. Tradução de Roberto Muggiati. Revisão da Tradução de } \\
\text { Moacyr Scliar. }\end{array}$ \\
\hline 2005 & $\begin{array}{l}\text { The March } \\
\text { Em português: A Marcha. São Paulo, Rio de Janeiro: Editora Record, } 2007 . \\
\text { Tradução de Roberto Muggiati. Revisão da Tradução de Moacyr Scliar. }\end{array}$ \\
\hline
\end{tabular}




\begin{tabular}{|l|l|}
\hline 2009 & $\begin{array}{l}\text { Homer \& Langley } \\
\text { Em português: Homer \& Langley. Rio de Janeiro: Record, 2011. Tradução de } \\
\text { Roberto Muggiati. }\end{array}$ \\
\hline 2014 & Andrew's Brain \\
\hline
\end{tabular}

